DOI: $10.17242 / M V v K \_30.02$

\title{
A VADÁSZAT HATÁSA A VÍZIVAD POPULÁCIÓKRA MAGYARORSZÁGON
}

\author{
EFFECT OF SHOOTING ON WATERFOWL POPULATIONS IN HUNGARY
}

\author{
Faragó Sándor
}

\begin{abstract}
Soproni Egyetem, Vadgazdálkodási és Gerinces Állattani Intézet
University of Sopron, Institute of Wildlife Management and Vertebrate Zoology

H-9400 Sopron, Bajcsy-Zs. u. 4. Hungary, e-mail: farago.sandor\&uni-sopron.hu
\end{abstract}

\section{BEVEZETÉS}

A Kárpát-medence, tudományterületünkön használt elnevezéssel a Pannon régió, $\boldsymbol{a}$ vízimadár vonulásnak és telelésnek az egyik kulcsterïlete. A Pannon régióban vonuló és telelö vízivad/vízimadár állományok helyzetének ismerete nélkül nem értelmezhető a NyugatPalearktisz vízivad fajainak státusa, nem alakítható ki stratégia védelmükre, fenntartásukra.

A fenntartáson ebben az esetben a védelmet célzó aktiv, fenntartó természet- és vadvédelmi beavatkozást, illetve a bölcs, fenntartható hasznositás elvü vadgazdálkodást értjük. A védelmi és a vadgazdálkodási tevékenység - az utóbbi, mint a természet erőforrásainak egyikével sáfárkodó ágazat - nemhogy kizárja, hanem egyenesen feltételezi egymást. Ezt erősíti meg az EURÓPAI UNIÓ BIZOTTSÁGA által kezdeményezett, a BIRDLIFE INTERNATIONAL és a FACE (EURÓPAI VADÁSZSZÖVETSÉGEK SZÖVETSÉGE) bevonásával kidolgozott, „Vadászható Madárfajok Fenntartható Hasznosításának Programja”, amely a Madárvédelmi Irányelv (79/409/EGK) mellékleteiben szereplö vadászható madárfajok köztük a vízivad fajok - bölcs hasznosítását hivatott elősegíteni. Talán Európában először, Magyarországon elkészítettük e program végrehajtási tervét is (BÉLTELKINÉ GÁL \& KovÁCS, 2004). Jelen munka e Program vízivadat érintő intézkedéseinek tudományos megalapozását is igyekszik szolgálni.

E célkitűzéseknek megfelelően az alábbi kérdésekre kívánunk válaszokat adni:

(1) Hogyan alakul a vadászható fajok terítékdinamikája, a vadászat jogi szabályozása biztosítja-e a bölcs hasznosítás szemléletének érvényesülését a gyakorlatban, azaz harmonikus-e a kapcsolat a populációméretek és a hasznosítás nagysága között?

(2) Valóban a leggyakoribb, azaz a legkevésbé sérülékeny fajok vadászhatók Magyarországon?

(3) Milyen hatással van a zárttéri tenyésztés és kibocsátás (tőkés réce) a vízivad vadászatára?

(4) Milyen ajánlások fogalmazhatók meg a gyakorlati vadvédelem számára Magyarországon?

\section{A BÖLCS VADGAZDÁLKODÁS HATÁSA A VÍZIVADRA - SZAKIRODALMI ÁTTEKINTÉS}

A vadászatnak a fészkelő és telelő populációkra gyakorolt hatásairól akkor kezdett tárgyalni a szakirodalom, amikor ezek a hatások egyértelmủen negatív tendenciákat kezdtek mutatni, azaz megvalósításuk sem lokálisan, sem regionálisan nem követte a fenntartható vadászat szellemiségét és gyakorlatát. A vadászat, mint a vadgazdálkodási integráns, hasznosítási periódusa - mint a gazdálkodási folyamat egésze is - tervszerüséget feltételez. Napjainkra kikristályosodott ennek az elmélete és gyakorlata egyaránt, amelyet a vadászatban, 
vadgazdálkodásban bölcs hasznosításnak, vagy bölcs vadgazdálkodásnak - általánosságban fenntartható, vagy tartamos gazdálkodásnak - hívunk.

E fogalomrendszer értelmezését az alábbiakban foglalhatjuk össze (ROBERSTON, 1991; FARAGÓ \& NÁHLIK, 1997). Bölcs a hasznosítás, ha a vadászat mértéke az optimálisan fenntartható hozam szintjén, vagy az alatt van, de a hasznosítás eredményeként kialakult költő populáció egyedszáma/sürüsége még mindig magasabb, mint az olyan populációké, amelyekre nem vadásznak és vadgazdálkodási eljárásokkal sem támogatják azokat. Bölcs vadgazdálkodás egy fajjal csak ott történik, ahol a bölcs hasznosítás (vadászat) mellett vadgazdálkodást is folytatnak, beleértve a megfelelő élőhelyek védelmét, fejlesztését, vagy létrehozását, illetve a dúvadpopulációk szabályozását, vagy mindezeknek a kombinációját. Ezek a vadgazdálkodási eljárások nem csupán kompenzálják a vadászatból eredő veszteségeket, hanem a beavatkozások előtti állapothoz képest magasabb szaporulatot, eredményeképpen magasabb állománysürüséget eredményeznek. A vízivad fajok többségének esetében - kivéve természetesen a szélsőségesen alacsony példányszámú fajokat - a védelemnek nem az a legjobb módja, hogy a hatóságok betiltják a vadászatot, $\mathrm{s}$ ezzel elvész a vadgazdálkodási beavatkozások alkalmazására motiváló tényező, hanem az, hogy felelősségteljes mértékü vadászatra serkentenek és előmozdítják a helyes vadgazdálkodást. Ez az út vezet a bölcs hasznosításhoz, amely javára válik mind az állatfajoknak, mind pedig a vadászoknak. A bölcs hasznosítás megvalósításának legalkalmasabb módja változó, attól függ, hogy milyen a vadászat és vadgazdálkodás színvonala. Ahol jelenleg tartamosan fenntartható a hasznosítás hozama, de a populáció denzitása alacsonyabb, mint ha az illető populációt sem nem vadásszák, sem vadgazdálkodással nem támogatják, ott szorgalmazni kell a vadgazdálkodási aktivitás növelését. Ahol pedig túlzottan nagy a vadászati nyomás, ott a vadgazdálkodás intenzitását növelni, a vadászati terhelést pedig csökkenteni kell.

Egy faj bölcs hasznosítására vonatkozó megfontolások - mint láttuk - viszonylag egyszerüek. A szóban forgó faj azonban valamely ökoszisztémának a részét képezi. A hasznosítandó faj javát szolgáló vadgazdálkodási eljárások szükségszerüen hatást gyakorolnak ugyanazon ökoszisztémához tartozó más fajokra is (ROBERTSON, 1991). A beavatkozások a célfajon kívül számos más fajnak is javára szolgálnak, hiszen az élőhelyek minőségének javítása mellett, a vadgazdálkodás növelheti az értékes élőhelytípusok mennyiségét is. Az okszerü dúvadgazdálkodás fontos szempont a vízivad gazdálkodás terén is. E tevékenységnek a célja sok esetben populációik csökkentése, de ezen állatfajok válogatás nélküli üldözésének a napjai már elmúltak. Jelenleg a dúvadgyérítés legális módszerei és a veszélyeztetett ragadozómadár fajok védelmére hozott rendeletek azt igazolják, hogy az állományszabályozás csupán a gyakori fajok - pl. a róka (Vulpes vulpes) és a vadászható varjúfélék (Corvidae) - populációinak korlátozására irányul. Az a tény, hogy a vadgazda korlátozza a dúvadfajok állományait abból a célból, hogy aztán több vadat hozhasson terítékre, esetleg megkérdőjelezhetőnek tünik. Miért nem próbálják meg inkább mind a vadászható vadfajokat, mind pedig ezek predátorait védeni, engedve, hogy a természet maga alakítsa ki saját „egyensúlyi” helyzetét? A fenti érveléssel kapcsolatos problémák kettősek. Először is: tájainknak túlnyomó többségét az ember alakította ki, pl. a vizes élöhely lecsapolása, átalakítása, valamint a modern mezőgazdálkodás által. Ez a folyamat már önmagában véve is felszámolt mindennemü „természetes egyensúlyt”. Azután bőséges táplálékforrást nyújtottunk sok ragadozó számára, ami a mesterségesen magas sürüségük kialakulását eredményezte. Másodszor pedig az említett érvelés figyelmen kívül hagyja az egyéb jótékony hatásokat, amelyek valamely vadászható vadfaj ésszerű hasznosításából adódnak. Olyan területeken, ahol nem folytatnak dúvadszabályozást valószínütlen az, hogy a vadfajok olyan sürüség-értékeket érjenek el, amelyek az élőhelyek vadgazdálkodási célú kezelését gazdasági szempontból indokolt és érdekelt feladattá teszik. Ez esetben mind a vadászható vadfajoknak, mind pedig predátoraiknak az állományai csökkenni fognak, 
minthogy a környezethasználat intenzívebb szintje nyomást gyakorol élőhelyeikre. Ott viszont, ahol a dúvadszabályozás megtörténik, az élőhelygazdálkodás hatásai sokkal eredményesebbek, és a magasabb sürüségü vízivad állomány jelenléte igazi okot szolgáltat a környezet megóvására és minőségének javítására. Előfordul az is, hogy a vadgazdálkodás és a vadászat nem jelenti az adott faj ésszerü hasznosítását - pl.: a tőkés réce állományt mesterségesen tenyésztett madarak kihelyezésével tartják fenn - ennek ellenére a terület vadgazdálkodási célú kezelése és fejlesztése (erdőfoltok létesítése és megőrzése stb.) jótékony hatást gyakorol az ökoszisztémára.

Egy-egy vadfaj bölcs hasznosítása is lehet kitüzött cél egy adott területen, de inkább az egész ökoszisztéma bölcs gazdálkodásának kell elsőbbséget kapnia. A vadgazdálkodásnak egy ökoszisztémába való integrálása során alaposan mérlegelni kell mindazon következményeket, amelyek pozitív vagy negatív változásokat okozhatnak, s csak ezek után szabad rátérni a megvalósításra.

Mindezen bevezető után tekintsük át a bölcs gazdálkodás elemeinek - a hasznosításnak és az élőhely-gazdálkodásnak - a hatásait a vízivad állományokra.

\subsection{A VADÁSZAT HATÁSA A VÍZIVAd ÁLLOMÁNYOKRA}

Mivel a legtöbb vízimadár/vízivad költőző, a vadászat hosszú távú hatásait, következményeit egy populáció számára - amely halálozásban, vagy a szaporodási teljesítményben mérünk - jóval nehezebb igazolni, mint helyhez kötött fajok (pl. mezei fajok) esetében (BELL \& OWEN, 1990). Egyelöre csak közvetett bizonyítékokkal képes a tudomány manipulálni (MADSEN \& FOX, 1995), ami azzal a veszéllyel jár, hogy a természetesen fennálló hibalehetőségek mellett a megközelítés szubjektivitásának lehetőségét is magán hordozza. Feldolgozásunkban inkább az objektív bizonytalanságot tartjuk helyénvalónak, mint a szubjektivitás térnyerését billentse az a véleményt akár pro, akár kontra a vadászat megítélése tekintetében.

\subsubsection{A vadászat, mint állománycsökkentő tényező}

A vizes élőhelyek kedvező ökológiai adottságaikat csak akkor érvényesíthetik, azaz akkor nyilvánulhatnak meg azok, meghatározva a vadeltartó képességet, ha a vizes területeken bizonyos időszakokban, de legalább a szaporodási időszakban nyugalom van. A zavaró tényezők - legkülönfélébb gazdálkodási formák - közül feltétlenül a vadászat az, amelyik az egyik legnagyobb rizikófaktor. Szerepének tényleges tisztázásához, megítéléséhez, különösen pedig a bölcs gazdálkodás elvének érvényesítéséhez mindenképpen ismerni kell a vadászatnak, mint terhelésnek a hatásmechanizmusát.

A vadászatnak a vízivadra gyakorolt hatását NowAK (1976) nyomán mutatjuk be (1. ábra). Kisebb - bár napjainkban ismét nem elhanyagolható - jelentősége folytán először az illegális vadászattal foglalkozunk (1.a). A vadorzók által befogott, vagy más módon elpusztított egyedekböl (6), a tojásgyüjtésböl (5) származó ismeretlen veszteség (7) nem nagy, amit az esetleges tilalmi időben illegálisan lelőtt példányok sem emelnek meg lényegesen. A vízivad legális vadászata során a vadászok (1) által vadászható fajok (2) körét, a naponként és vadászonként terítékre hozható egyedek számát rendelet szabályozza. A vadászat alkalmával a populációnak csak egy része hozzáférhetö (3a) a vadászok számára, másik részét csak zavarják (3b), míg a további hányadot a környezeti és egyéb tényezők miatt nem érhetik el (3c). A hozzáférhető egyedeket (3a) eltalálják (4a), befogják (4b), vagy sértetlenül továbbrepülnek (4c) a populáció zavart egyedeinek (9c) sokaságával. Az eltalált vízivad (4a) nagy hányadát felveszik, terítékre kerül, és a statisztikákban feljegyzik (10a), kisebb része 

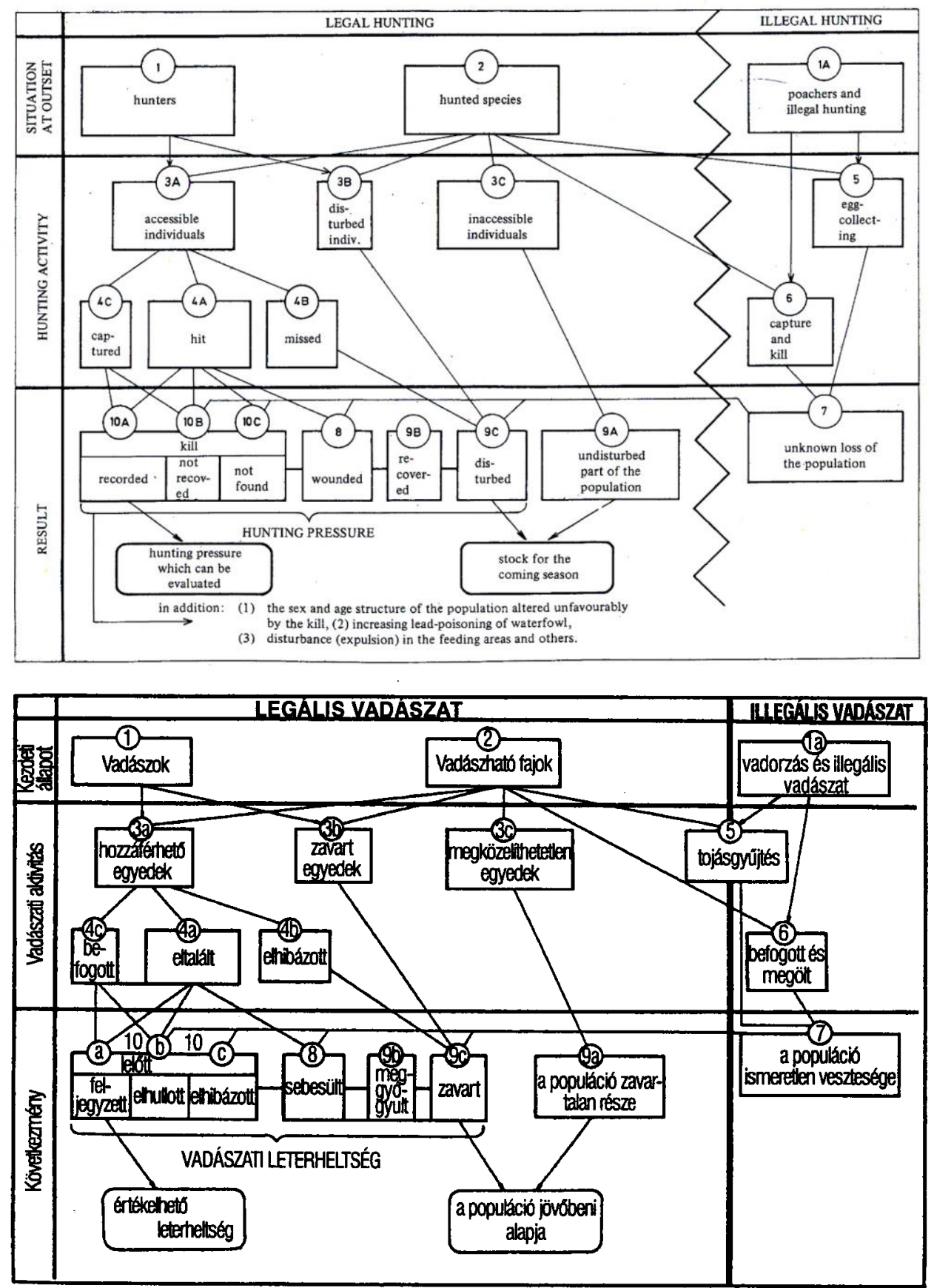

1. ábra: A vadászati nyomás hatása a vízivad állományra (NowAK, 1976) Figure 1: Effect of hunting pressure on waterfowl populations (NOWAK, 1976).

elhullik (10b), vagy elveszik (10c). A vadászat elkerülhetetlen mellékhatása a sebzés (8), amely egyedeknek egy része meggyógyul $(9 b)$, a másik része vagy utánkereséskor megkerül (10a), vagy elhullik, elveszik (10b,c). A lelőtt (8), a sebesült (8), a meggyógyult (9b) és a zavart (9c) egyedek összességével jelölhetjük egy populáció vadászati leterheltségét, amiből az értékelhető csupán a feljegyzett teriték nagysága (10a). A megadott terítéknagyságokat nem szabad összetéveszteni azzal a tényleges igénybevétellel, aminek vadászható fajaink itt telelő és átvonuló populációi ki vannak téve. A populációk megközelíthetetlen, zavartalan része (9a), a zavart, de túlélő (9c) hányada alkotja azt a szülőnemzedéket, amely alapja lesz a következö év sikeres költésének. Ennek a nagysága szoros kapcsolatban van a vadászati 
leterheltséggel, a vadászati nyomással. A vadgazdálkodó feladata megtalálni a bölcs hasznosítás kényes mértékét.

A vadászat hatásait mérhetjük a mennyiség és a minőség szemszögéből, azaz befolyásolhatja az állományok egyedszám-dinamikáját, de alakíthatja a populációk egyéb struktúr paramétereit (ivari- és korviszonyok, diszperzió, kondíció, termékenység, viselkedés) is. A hatás értékelésekor érdemes mindezt figyelembe venni.

BOYD (1984) kimutatta, hogy az úszó- és bukórécék terítéke a vadászati szabályozás (vadászidény hossza, napi terítékkorlátozás) változásának megfelelően ingadozik, azaz szigorúbb szabályozással csökken, megengedőbb feltételek mellett növekszik nagysága. Már GEIS (1963) és KALCHREUTER (1987) is rámutatott, hogy a gyakoribb vadelöfordulással emelkedik a vadászati érdeklódés, egyszersmind az elejtett vadlétszám, azaz a populációkba történő beavatkozási arány, de az ellentétes irányú folyamat is igazolható. Ezt a megállapítást azonban több tényező is módosíthatja, pl. a napi terítékkorlátozás, a fajok eltérő mérete (zsákmánynagyság), eltérő vonulási tulajdonságaik, különböző elérhetőségük. SCHIFFERLI (1982) a Bodeni-tónál több éven keresztül végzett vizsgálataiban igen szoros kapcsolatot talált a teríték nagysága és spektruma, illetve a területen megfigyelt récefajok egyedszáma és dominanciaviszonyai között, azaz a gyakoribb fajokat ejtették el a leggyakrabban, a kisebb egyedszámúakat arányosan ritkábban. Az egyes években a hasznosítási arányok eltérést mutatnak, amelynek okát a vonulás intenzitásának vagy a fiatalok részarányának, ezáltal a fajok egyedszám- és dominanciaviszonyainak megváltozásában találhatjuk meg.

FOG (1971) kimutatta, hogy a fiatal egyedek - tapasztalatlanságuk következtében nagyobb valószínüséggel ejthetők el, mint az idősebbek. A mindenkori korstruktúra, azaz a fiatalok aktuális aránya tehát befolyásolja a teríték nagyságát.

Az őszi vadászati hasznosítás állománycsökkentő hatása - amely az elhullást okozó természetes okok mellett többletterhelésként éri a populációkat - fontos tényező az állományok nagyságának hosszútávra történő tervezése során. Hagyományosan két szélsőséges nézetet vallanak a kutatók (AEBISCHER, 1991). Az egyik felfogás szerint a hasznosításból eredő állományveszteség teljes mértékben additív, vagyis többletként hozzáadódik a természetes, a környezet hatásai (időjárás okozta elhullás, zsákmányolás stb.) kiváltotta veszteségekhez. Vízivad vadászat vonatkozásában ezt a nézetet képviselte GEIS (1963), valamint OGILVIE \& COOK (1972). A másik nézet szerint viszont, a vadászat csupán a természet által amúgy is pusztulásra ítélt egyedszám-többletet távolítja el a populációból. Ha vadászat híján nem történne állománycsökkenés, akkor azt úgyis kompenzálja a természetes mortalitás. A teljes kompenzációt valló nézet viszont azt feltételezi, hogy a természetes mortalitás tökéletesen sürüség-függő. Habár a szárnyasvadfajoknak jellegzetes biológiai sajátossága a sürüség-függő mortalitás - a vizsgálatok azt is kimutatták, hogy a teljes kompenzáció még akkor is ritkán következik be, ha a hasznosításból fakadó egyedszám csökkenés aránya alacsony (AEBISCHER, 1991).

A valóságot tükrözö nézet minden bizonnyal a két szélsöséges felfogás között helyezkedik el, és bonyolódik a helyzet, ha sürüség-függö viszonyok jellemzik az illetö faj szaporodását. A tőkés récére (Anas platyrhynchos) vonatkozó részletes vizsgálatok megerősítették, hogy a vadászatból eredő veszteségek részleges kompenzálása mutatható ki (ANDERSON \& BURNHAM, 1978). A tőkés réce állomány ugyanis nem növekedett azáltal, hogy a vadászata betiltásra került. Ugyanerre a megállapításra jutott ROGERS et al. (1979) is, azaz nem talált nagyobb összes mortalitási értéket a magasabb vadászati nyomás éveiben, $\mathrm{s}$ ugyancsak nem csökkent a halandóság az alacsonyabb terítékü években. NicHOLS \& HiNES (1983) megerősítették a korábbi megállapításokat, amennyiben a vadászat csak bizonyos keretek között tudja a többi halálozási tényezőt helyettesíteni. ANDERSON \& BURNHAM (1978) megállapították, hogy van egy olyan küszöb (threshold), amely fölött a vadászati hasznositás nem kompenzáló, hanem additív halandósághoz vezet. 
Ha a vadászott és nem-vadászott populációkban a halandósági ráták közel azonosak, akkor az első esetben az el nem ejtett récéknek jobb életfeltételek között kellett élniük, ill. kisebb mértékben estek áldozatul természetes pusztító tényezőknek (táplálékhiány, betegség, fedettség hiánya, stb.) az után, hogy a sürüséget a vadászat csökkentette. A vadászat tehát csak a sürüség-függő halandóság mértékében kompenzáló. Mekkora ennek részaránya a teljes halandóságban? Különösen ott lehet nagyon magas, ahol egy populáció a saját életterét messzemenően kitölti. Ennek alapján a fenti kérdést a következőképpen lehet megválaszolni:

- A kompenzáló és additív halandóság közötti küszöb egy faj teljes halandósági rátájának nyilván a közelében, de mindig az alatt van.

- Magas öszi sürüségnél a populációnak nagyobb részarányát, alacsony sürüségnél csak kisebb hányadát lehet elejteni anélkül, hogy a populáció sürüségcsökkenése következtében a következö tavasszal a költö állományt lényegesen ne befolyásoljuk.

Ettől eltekintve az egyes fajoknak eltérő vadászhatósága adódik a fajspecifikus átlagos teljes halandóságuk alapján: az r-stratégisták, vagyis a legtöbb úszóréce vadászatilag nagyobb mértékben hasznositható, mint a K-stratégisták, azaz a tengeri récék vagy a ludak. PATTERSON (1979) szerint a nevezett küszöb az úszó récéknél kb. 40\%-os elejtési aránynál van, míg azt a tipikus K-stratégáknál $\mathbf{1 0 \%}$ fölött már kritikusnak tartja. A tényleges vadászati intenzitás az egyes fajoknál nagyjából megfelel a bemutatott felismeréseknek. Az úszórécéket vadásszák leginkább; de vadászat-ökológiai vizsgálatok néhány további fajnál ugyanazokat az eredményeket szolgáltatták, mint a tőkés récénél. BOYD et al. (1978) a kendermagos récénél (Anas strepera) és az amerikai fütyülö récénél (Anas americana) sem tudta a vadászatnak az állomány alakulására való hatását kimutatni. HOPPER et al. (1975) szerint a költő populáció mindenkori nagyságára a költési időszak előtti és alatti élőhelyi viszonyoknak nagyobb hatással vannak, mint a vadászati nyomásnak. Ennek ellentmond BELL \& OWEN (1990) azon megállapítása, mely szerint a vízimadár populációkat telelő és pihenő területeik eltartó képessége jobban korlátozza, mint a szaporodási területen rendelkezésre álló források.

Mi történik, ha a vadászat, a kompenzáló és additív mortalitás közötti küszöböt jelentősen túllépi, tehát amikor az intenzívebb vadászat a mortalitási rátát megnöveli, ill. a költő állományt jelentősen csökkenti? (Bár ez nagy területen és hosszú távon nagyon ritkán szokott bekövetkezni.) Helyi tőkés réce populációkra vadászhatnak olyan intenzíven, hogy a fiatal madarak halandósága 70\%-ra, az idősebbeké pedig majdnem 60\%-ra nőhet meg [erre vonatkozó példák a régebbi, a modern vadászati szabályozást megelőző időszak szakirodalmában (BRAKHAGE, 1953; BOYD 1957, FOG, 1965) lelhetők fel]. A nagy predációs nyomás vagy szélsőséges téli időjárás következtében is lényegesen (az átlag alá) csökkenhet a tavaszi költő állomány. Végül azoknál a fajoknál, ahol nagyon alacsony a természetes összes mortalitás - mint a ludaknál vagy hattyúknál (nagy liliknél EBBINGE (1991) szerint 6\%) - még a kisebb beavatkozások is vezethetnek magasabb pusztulási rátákhoz, és ennek révén állománycsökkenéshez.

Mindezek ellenére az utóbbi években mind Európa nagy részén (az Európában megjelenő, vadászható tömegfajok szinte mindegyikénél), nemkülönben Észak-Amerikában, a telelő vadlúd populációknál legalább stagnáló, de még inkább emelkedő egyedszámot lehet kimutatni annak ellenére, hogy a vadászati nyomás nem csökken.

A magyarázat feltétlenül a fajok szaporodási stratégiájában keresendő. A szaporodás eredményességét, azaz a felnevelt szaporulat arányát több tényező (korstruktúra, kondíció, klimatikus tényezők, predáció, táplálék forrás-kínálat, kompetíciós viszonyok stb.) befolyásolja. Közülük is kiemelkedik a táplálék kínálat, illetve a fészkelőhelyek vagy takarás, mivel ezek csak korlátozottan állnak rendelkezésre. Ennek megfelelően a szaporodási rátát miként a halandósági rátát is - az állomány sürüsége lényegesen befolyásolhatja. Az állatpopulációk ugyanis az egyedszám-csökkenésre törvényszerüen intenzívebb szaporodással reagálnak azért, hogy a bekövetkezett veszteségeket kiegyenlítsék. Ez a kompenzációs 
mechanizmus a legtöbb fajnál a csökkent természetes halandóság hatását még túlszárnyalni is képes (összefoglalás KALCHREUTER, 1984).

A vízimadár fajok is rendelkeznek olyan jelentōs tartalék potenciállal, amely biztosítja, hogy a nagyobb veszteségeket növekvő szaporodási teljesítménnyel kiegyenlítsék. Ezt az alábbi szaporodásbiológiai kondíciók teszik lehetővé: (a) a korábbi ivarérettség, ezáltal a populáció magasabb termékenysége révén - az általánostól eltérően, fiatalabb korosztály is rész vesz a szaporodásban, (b) magasabb kelési arányok révén - amelyet alapvetően a magasabb fészekalj-nagyság tesz lehetővé, és (c) az utódoknak a röpképesség elötti magasabb túlélési aránya révén.

A túlélési stratégiától függően az egyes fajok eltérő módon növelik szaporulatuk számát, ha a költési sürüség lecsökkent:

Az r-stratégistáknak, vagyis a legtöbb úszórécének tág fészekaljanként a tojásszám nagysága (hazai viszonyokra lásd FARAGÓ, 2002e), széles a kotlás-gyakorisági és a túlélési arány spektruma. Az egyéves récetojók szaporodási rátája jelentősen megnő alacsonyabb költési sürüség esetén - a populáció teljes szaporodási teljesítményére gyakorolt kiemelkedő hatással - hiszen abban az egyéves madarak (a korosztály dominanciája miatt) nagy számmal vannak képviselve. Az erőteljesen vadászott, akkor még különösen nem korlátozott dániai tőkésréce populációban a fészkek több mint a felében tíz, vagy annál több, átlagosan fészkenként 9,6 tojás volt, és tojónként átlagban 5,0 és 7,5 kiskacsa érte meg a röpképes kort (FOG, 1965). Ezek messze az átlag fölötti számok (lásd FARAGÓ, 2002e), ami a kompenzálómechanizmusok aktivizálódását mutatja.

Az inkább K-stratégista fajok - mint pl. a bukórécék és részben a tengeri récék - a valamivel kisebb és szükebb fészekalj nagyság (FARAGÓ, 2002e) következtében kevesebb kompenzációs lehetőséggel rendelkeznek. E fajok esetében alacsonyabb sűrüségnél a tojók hamarabb lesznek ivarérettek. A bukórécék nagyobb része már az első, a tengeri récék a második életévükben kotlanak. A fiatalok korai halandósága is jelentősen lecsökken a nőstények költési sürüség csökkenésével. Ez a jelenség még inkább kimutatható a tipikusan K-stratégista ludaknál és hattyúknál. Ugyanakkor mindez fordítva is megfigyelhető, azaz magas sürüség esetén a szabályozás a későbbi (3-5. évben) kotlás kezdéssel és alacsonyabb felnevelési ráta révén történik meg. A vadludak is szinte kizárólag a szaporodáson keresztül szabályozzák sürüségüket. (többek közt lásd OWEN, 1982; 1984; OGIVIE, 1982; COOCH et al., 1989; EBBINGE, 1991; 1992). A fészkelö-területek eltartó képességét meghaladó állománysürüség esetén alacsonyabb, az eltartóképesség alatti denzitás esetén pedig magasabb lesz a termékenységi arány, a szaporodási teljesítmény. A vadászat ezeknél a hosszú életű fajoknál az alacsony halálozási ráták növekedéséhez vezethet, olyan évek kivételével, amelyekben a tél szigorú és a táplálékbázis nagyon lecsökkenhet, és ennek következtében a sürűségfüggő halandóság a populációt ismét megtizedelheti. A vadászat ebben az esetben is kompenzálja a teljes halandóságnak egy részét, ami rendszerint megnöveli a mortalitást, és valamelyest megváltoztatja a populáció ivari- és korszerkezetét.

OWEN (1984) az apácalúd (Branta leucopsis) állományok növekedésének fő okát a táplálékban gazdag védett területek kialakításában, azaz a táplálékkínálat növekedésében látta. BOYD (idézi KALCHREUTER, 1987) az 1970-es és 1980-as évek enyhébb téli időjárásának jelentőségét hangsúlyozta. Mindkét tényező nyilvánvalóan meghatározóan hozzájárult a ludak eredményesebb túléléséhez. Ezt a megállapítást alátámasztják a vadászott lúdfajokkal végzett vizsgálatok. Ezek ugyanis hasonló mértékben és érdekes módon ugyanattól az időtől kezdve növelték meg állományaikat (OGILVIE 1978, HEPBURN 1984). Jól összehasonlítható az örvös lúd (Branta bernicla) és a nagy lilik (Anser albifrons) állományalakulása. Mindkettő Oroszország kiterjedt északi vidékein költ, mindkettő megsokszorozta állományának nagyságát az 1970-es, 1980-as években, noha az örvös ludat alig, ezzel szemben a nagy liliket majdnem teljes vonulási és telelési területén vadászták. Az 
egykorú holland vadászati statisztika a terítéknek az állomány növekedésével megegyező dinamikáját mutatta: 1978/79-ben 7000 pld, 1983/84-ben már 25.000 pld nagy liliket ejtettek el (KALCHREUTER, 1987), miközben a hasznositási arány csaknem állandó maradt, az áttelelő madarak 5,1-9,1\%-a került terítékre. Hasonló eredményeket mutattak más vidékeken más lúdfajokkal végzett vizsgálatok. PIRKOLA \& KALINAINEN (1984) szerint Finnországban a vetési lúd (Anser fabalis) vadászati terítéke 1976-től 1980-ig majdnem megduplázódott (2500 pld-ról, 4800 pld-ra), ennek ellenére a vetési lúd állománya és fészkelö területe is nőtt.

A régóta folyó észak-amerikai vizsgálatok alapján ismertté vált, hogy az őszi állománynak mintegy 20\%-a hasznosítható anélkül, hogy a vadászat az állományalakulást érdemben befolyásolná (TROST \& MALECKI, 1985). Hasonló elejtési arányokra enged következtetni TVEIT (1984) tanulmánya, amely szerint 600 meggyürüzött svéd vetési lúdnak valamivel több, mint 10\%-a lett elejtettként visszajelentve. EBBINGE (1991) ezzel szemben évi 6\%-ban adja meg a nagy lilik természetes halálozási arányát, amely mellett a vadászati mortalitás nem nevezhető kompenzálónak, mivel amennyiben a lelövés véletlenszerü esemény, akkor a lelőtt madaraknak csak 6\%-a pusztult volna el mindenképpen. Azt azonban elismeri, hogy ha csökkentjük a teljes populációméretet, akkor a vadászat közvetett módon, kis mértékben javíthatja (növelheti) a költési eredményt.

A vadászattal szembeni fenntartások vadludak esetében az úgymond élethossziglani párkapcsolatok megszakadása miatt erősödtek fel az elmúlt időszakban. A párkapcsolat kérdését azonban az újabb vizsgálatok más megvilágításba helyezik, ami az eddigi ismeretek felülvizsgálatára késztet bennünket. Egyedileg megjelölt sarki- és kanadai ludak (Anser caerulescens et Branta canadensis) pontosabb vizsgálatai igazolták a rendszerint többéves partneri kapcsolatot, de jelentős arányban partnerváltást is kimutattak. Kanada sarkvidékén a sarki lúd (Anser c. caerulescens) megvizsgált 229 költő párjának több mint egyharmada váltott párt évről évre (COOKE et al., 1981). A párcsere még közvetlenül a költési idő előtt, sőt annak során megtörténhet akkor is, amikor arra nem volt semmi felismerhető ok (pl. a partner elhullása) (MACINNES et al., 1974). Az idős sarki ludak sem maradnak ősszel és télen mindig párban. Leginkább sikeres költés után erősödik a párhűség, amelynek során a fiatal madarak nyilvánvalóan stabilizáló hatással vannak a szülők kapcsolatára (PREVETT \& MACINNES, 1980). Magától adódik ilyenkor a kérdés: milyen hatással van a párváltás a költési sikerre? COOKE et al., (1981) fent említett vizsgálataik során nem találtak különbséget a többéves és újonnan párba álltak szaporodási teljesítménye között. Az új párok valamivel kisebb tojásszáma elsősorban az először költő libák nagyobb részarányának volt a következménye. A fiatal tojók általában kevesebb tojást tojnak, mint az idősebbek. A kislibák túlélési aránya a röpképességig mindkét csoportban azonos volt, vagyis a kevésbé bevésődött magatartásminták az újonnan párba állóknál - legalábbis a sarki lúd esetében - nem volt negatív hatással a költési sikerre (COOKE et al., 1981). Ezzel szemben OwEN et al. (1988) az apácalúd (Branta leucopsis) populációk vizsgálatakor úgy találták, hogy az ismert társtól való különválásnak súlyos ára van, mivel a társát vesztett madárnak mindössze $8 \%$-os esélye van a sikeres szaporodásra a veszteséget követö évben, míg a párban maradt ludak esetében $21 \%$-os valószínüségre számíthatnak. Ha a társak szétszakítása tavasszal is folytatódik (egyes orosz területeken tavaszi vadászat révén), annak további, a szaporodási teljesítményt negatívan befolyásoló, káros hatása van.

A korábbi aggályt, tehát hogy az öszi-téli vadászatnak erösen negatív hatása volna a lúdpopulációk szaporodási rátáira, a vizsgálatok egyértelmüen nem erősítették meg, sōt ennek ellentmondani látszik a vadászott fajok állományainak növekvö állományalakulása.

Az elmondottak alapján tehát két olyan mechanizmus létezik - a csökkenő, sürüségfüggő halandóság és magasabb szaporodási arány - amelyek az vízivad populációkban müködésbe léphetnek a veszteségek kiegyenlítése érdekében. A stratégiai típustól (r, vagy K) függően kerül túlsúlyba az egyik vagy a másik kompenzációs mechanizmus. Ámde az 
átmenetek egy fajon belül is folytonosak, miként azt az angol példa (HILL, 1983; 1984) szemlélteti.

Az öszi tőkés réce (Anas platyrhynchos) csapatoknak milyen arányát lehet hosszú távon vadászatilag hasznosítani?

- Az őszi alacsony hasznosítási rátáknak a következő évi költő populációra csak csekély hatása van, 20\%-ot meghaladó hasznosítás esetén azonban a populáció egyre határozottabban csökken. Tehát az átalakulás a kompenzációs halandóságból az additívba inkább folyamatos átmenetet mutat.

- Ám a költő populáció sűrüségének csökkenésével nő annak szaporodási rátája, úgyhogy az öszi állomány ismételten eléri a nem vadászott állomány nagyságát. Ennek megfelelően nő a hosszútávon fenntartható vadászati teríték - de csak mintegy 40\%-os hasznosítási ráta mértékéig. Az ennél nagyobb beavatkozásokat már nem lehet kompenzálni, az őszi állomány és ezzel együtt a teríték csökkeni fog. Az inflexiós pont a maximálisan fenntartható hozamnak felel meg, ami ebben az esetben azt jelenti, hogy:

- 40\%-os hasznosítási aránynál lehet tartamosan elérni a legmagasabb terítéket, amelynek során a költő populáció a nem vadászotthoz képest mintegy $25 \%$-kal lecsökken, de ezen a szinten stabil marad.

- Magasabb hasznosítási arányok nemcsak csekélyebb vadászati terítéket, hanem a költő populáció lényegesen alacsonyabb sürüségét is eredményezné.

\subsubsection{A vadászat, mint zavaró tényező}

Napjainkra a zöld szervezetek részéről egyre erősödik a vadászatra gyakorolt nyomás, a vízimadarak vadászatának betiltását, vagy legalábbis jelentős korlátozását követelve. Az ilyen követelések önmagukban nem újak, ám az érvrendszer ma más, mint amilyen még néhány évvel ezelőtt is volt. Akkoriban a „vízivad állományainak veszélyeztetése” állt az előtérben, beleértve a tudományos publikációkat is. Időközben azonban - ahogy bemutattuk nagyszámú idevágó vadászati-ökológiai vizsgálat történt, valamint a legtöbb fajnál - a vadászat mellett - az állomány pozitív alakulása is megfigyelhető volt. Ezek az érvek a vadászat negatív hatásait részben megcáfolták.

Ma a leglényegesebb problémát a gázló és vízi madaraink életritmusának, általában élettevékenységének a vadászat, általi megzavarásában látják (EBBINGE, 1991; MADSEN \& Fox, 1995). Az új megközelítés szerint a telelés szempontjából életfontosságú táplálkozó területek és pihenőhelyek értéküket vesztik. A vadászható fajokkal együtt valamennyi védett vízimadarat elriasztja a vadászati aktivitás, kényszerítve őket arra, hogy máshol telepedjenek le. A helyváltoztató repülések azonban energiát igényelnek, és a kitéröhelyek rosszabb életfeltételeket kínálnak. Kemény telek esetén a többlet mozgás negatívan hat ki az egyedek energiaháztartására, felélik tartalékaikat, ami kondícióromláshoz vezet. A legyengült madarak - az ugyancsak energiaemésztő vonulás után kimutathatóan kevesebb fiatalt nevelnek fel. E nézet szerint a vadászat a madaraknál egy egész ,zavarási-láncolatot” vált ki (KALCHREUTER, 1987).

A teljes ,zavarási láncolatot” a kutatásoknak még nem volt módjuk végigkísérni, így a spekulatív gondolatsornak leginkább csak arra a kézenfekvő igazságára mutattak rá, hogy a récék elkerülik azokat a helyeket, ahol fegyverropogás van (MELTOFTE 1982, SCHIFFERLI, 1982).

További kérdés, hogy milyen messzire készteti, és mennyire tartósan tartja távol a vadászat az adott térségtől a vízivadat? A megfigyelések azt mutatják, hogy

- vadásznapokon, a területen ugyan kevesebb réce tartózkodik, de a közvetlenül határos vizeken jelentős feldúsulás tapasztalható 
- már egy-két órával az után, hogy a vadászok álláshelyüket elhagyják, ismét feltünnek ott a récék;

- ha a löállás táplálékban különösen gazdag helyen van, (pl. sekélyvízi zónában), akkor a lövések ellenére ismételten odarepülnek elsősorban úszó récék (KALCHREUTER, 1987).

Ezek a megállapítások egyébként összevágnak azokkal a megfigyelésekkel, amelyeket botulizmussal veszélyeztetett vidékeken végeztek, amikor a madarakat lövésekkel szándékosan el akarták riasztani, hogy a fertőzés továbbadását megakadályozzák. Sem Amerikában (PARRISH \& HUNTER, 1969), sem Németországban (KALCHREUTER, 1987) nem voltak eredményesek e kísérletek, mert a récék a riasztás után gyorsan visszatértek kedvelt pihenő- és táplálkozó területeikre. Ebböl arra következtetünk, hogy minél gazdagabb táplálékban egy terület a vízimadár fajok számára, annál kevésbé engedik magukat onnan elüzni.

Ilyen célból kialakított védett területek - rezervátumok, refugiumok - minden esetben a vízivad állomány határozott állománynövekedését vonta maga után. Ha e területeken biztosított a zavarásmentesség (általában és vadászati szempontból különösen), akkor a vadászatmentes zónákban alakulnak ki a legnagyobb madárkoncentrációk (MADSEN \& FOX, 1995). A madarak ráadásul nem feltétlenül csak a koncentrációval igazolják vissza a kíméleti területek ,jóságát”, hanem azzal is, hogy meghosszabbítják tartózkodási időszakukat a területen, azaz a vonulási útvonal néhány különösen kedvező területén egyfajta „torlódás” alakul ki, míg a vonulási útvonaltól távolabb eső területeket „elvesztették” (MADSEN et al., 1995). És viszont is igaz a helyzet, minden zavaró tevékenységet, beleértve a vadászati zavarást is úgy tekinthetjük, mint nettó élőhely veszteséget.

A récék ugyanakkor nemcsak a jó táplálkozó-területeiken tartózkodnak, hanem zavarás nélkül is, közép vagy akár hosszú távú repüléseket végeznek. Erre a megállapításra jutott FOG (1968) egy dániai récecsapdában megfogott és meggyürüzött csörgőrécék (Anas crecca) 180 visszajelentésének kiértékelése után. Már a gyürüzés napján elejtett madarak átlagosan $8 \mathrm{~km}$-t az egy nappal később zsákmányoltak $47 \mathrm{~km}-\mathrm{t}$ tettek meg. A megtalálás helyei nem a vonulás irányában feküdtek (azaz nem a vonulás részeként történt meg az elmozdulás), hanem a jelölés helytől északra, délre és keletre is. FOG (1968) szerint ezt csak úgy lehet megmagyarázni, hogy a pihenő récék nem maradnak kizárólag egy meghatározott területen, hanem más táplálkozó- és/vagy pihenőhelyként szolgáló vizeket is felkeresnek. A hazai gyürüzési adatok hasonló rövid és hosszabb távú - nem a telelőterületek felé irányuló mozgásokat mutatnak a legtöbb vízivad faj esetében (FARAGó, 2000a). Az amerikai vízivad gazdálkodási gyakorlatban a récék napi akciórádiuszát - tapasztalati értékek alapján - 30-50 km-nek feltételezik, és eszerint különítenek el vadászati pihenőzónákat/ kíméleti területeket (,refuges”) (COOCH, idézi KALCHREUTER, 1987).

Mennyiben akadályozza a vadászati zavarás a récék táplálékkeresését? A vadászat módja alapvetően meghatározza a zavarás mértékét, annak megfelelően a táplálkozásra fordítható időalapot. MADSEN et al. (1992) vizsgálatában kimutatta, hogy az álló vadászcsónak 8 perces, a kacsákat üldöző mozgó vadászcsónak 46 perces, ugyanennek a másodszori zavarása 168 perces kiesést jelentett a megzavart fütyülő récék (Anas penelope) táplálkozásában. Általában minél hosszabb táplálkozási időre van szüksége a vízivadnak ahhoz, hogy napi energiaszükségletét kielégítse, annál kevésbé képes pótolni az elveszett időt, annál kevésbé tolerálja a zavarást. Mivel a fütyülő récének csaknem egész nap táplálkoznia kell energetikai egyensúlya fenntartása érdekében, még egyetlen csónak zavarásából fakadó időveszteséget sem képes pótolni, többszöri zavarás esetén a a táplálkozási idő $25 \%$-át is elvesztheti.

Mind állóvizeknél, mind folyóvizeknél végzett vizsgálatok azt mutatták, hogy a bukórécék táplálékuk zömét az éjszakai órákban veszik fel, tehát a vadászattól mentes napszakban (KALCHREUTER, 1987). Ez a megállapítás azonban újabb kérdést vet fel: $\boldsymbol{a}$ 
madarak a nappali vadászati zavarás következtében kényszerülnek-e az éjszakai táplálékkeresésre, vagy ez megfelel normális életritmusuknak (amit eddig kevésbé ismertünk)? Mindkettőre akad példa! Brit vizsgálatok szerint (OWEN \& WILLIAMS, 1976) a vadászat módosíthatja a vízimadarak mindennapi életritmusát. A kíméleti területeken a fütyülő récék többnyire napközben táplálkoznak, ám azokon kívül - tehát olyan helyeken, ahol a vadászat zavaró hatása érvényesülhet - inkább éjszakai táplálkozásúak. Az éjszakai táplálkozás természetes voltát igazolta TAMISIER (1985) Camargue-ban, a csörgő récén (Anas crecca) végzett vizsgálata alkalmával. Ez a faj telelőterületén kizárólag éjszaka keresi táplálékát. TAMISIER (1985) ebből, és további idevágó vizsgálatokból azt a következtetést vonta le, hogy a récék normális esetben éjszaka vesznek magukhoz táplálékot, de ez a magatartás endogén hatásokra (mindenekelőtt a vonulás idején és hideg periódusok alatt fellépő nagyobb táplálékigény), vagy zavarások (pl. éjszakai vadászat) következtében módosulhat. Jelentősége van az áttelelési terület földrajzi helyzetének is: minél messzebb van az a fészkelő helytől, annál inkább túlsúlyba kerül az éjszakai táplálékkeresés. Így a „kacsahúzás” okát és jelentőségét is jobban meg tudjuk érteni: az esti repülések (tőkés réce, csörgő réce) rendszerint táplálékban gazdag helyekre történnek, amelyek gyakran messze vannak nappali tartózkodási helyektöl (FARAGÓ, 1991a; 1991b; 1993a; 1997c; 2002d).

Összességében a vadászati tevékenység minden más tevékenységnél ártalmasabbnak látszik a táplálkozás megszakitása miatt, amelynek káros energetikai hatásait csak az alacsonyan szálló repülögépek hatásával lehet összevetni (BÉLANGER \& BEDÁRD, 1990; MADSEN et al., 1992).

Mindezek alapján törvényszerü a kérdésfeltevés: a táplálkozás akadályozása, illetve a zavarás által kiváltott mozgásból adódó energiaveszteség okozhat-e végzetes energetikai defektust a telelés, a vonulás, vagy a fiókanevelés során?

A legtöbb vízimadárfaj képes arra, hogy pozitív energiamérleget tartson fenn december végéig, miközben a vonulási útvonal mentén található táplálékforrásokat hasznosítja a telelőterületek eléréséig. Ez tulajdonképpen a felhalmozás időszaka. December után azonban a legtöbb faj testtömege csökkenést mutat, s a külső körülmények (hideg, táplálékhiány) hatására eléri minimumát, mert a maximális táplálkozási erőfeszítések sem tudják fenntartani az eredeti kondíciót, így lebontják a felhalmozott energiaforrásokat. Ez a szakasz addig tart, amíg a tavaszi javuló körülmények, a táplálék mennyiségi növekedése és jobb hozzáférhetősége lehetővé teszi az elhasznált tartalékok pótlását (OwEN et al., 1992). Fenti okfejtésből következik, hogy a vadászat zavaró hatása késó télen hozzájárulhat a kimerüléshez, hiszen a madarak vagy nem tudnak hozzáférni a táplálkozási területekhez, vagy a megnött energiaráfordításokat képtelenek pótolni.

A madarak ugyanakkor nagyfokú adaptivitást mutatnak, ha arról van szó, hogy bepótolják az elveszett táplálkozási lehetőségeket, egyáltalán a táplálékhiányt. A táplálkozási aktivitás átrendeződése - amelyről már beszéltünk ennek egyik formája, amely ugyanakkor az éjszakai predációs veszély növekedését, a túlélési kockázatot is maga után vonhatja (MADSEN \& FOX, 1995).

A vízivad fajok jelentös része (föként a hosszú élettartamú fajok) a szaporodási terïletétöl távol esö helyeken halmozza fel a szaporodásba való befektetést szolgáló zsírkészletet. A madarak számos közbülső állomást használhatnak a végcélt jelentő szaporodási területekig, sőt néhány faj migrációs stratégiája úgy alakult ki, hogy ki tudja használni a megállóhelyek egész sorát az „újratöltés”-hez. Az ilyen területek elvesztése a vonulási útvonalak mentén, akár végzetes következménnyel is járhat egyes fajok számára. A gyenge kondícióban lévő állatok vonulás idején kimutatható túlélése kisebb, mint a jobb kondíciójú társaik. Több közvetett bizonyíték van arra vonatkozóan, hogy a vonulás folyamán elszenvedett veszteségek a vadászható fajok esetében korrelálnak a populációmérettel (OWEN \& BLACK, 1990). Az energiatartalékok képzésének azonban mindenekelött az a célja, hogy a 
tojó kellően felkészüljön a szaporodásra. Azok a madarak - pl. lúdfajok - amelyek nem tudtak kellö tartalékot felhalmozni, kevesebb utódot nevelnek. Ugyanakkor sok úszóréce faj esetében a szaporodáshoz szükséges fehérjekészlet a költőterületekről származik, ahol e források általában bőségben állnak rendelkezésre. Ugyanez vonatkozik a bukórécékre (Aythya és más nemzetségek) is (MADSEN \& FOX, 1995).

Mindezek alapján elmondható, hogy a vadászat zavaró hatásai valószínüleg leginkább a késö téli időszakban befolyásolják a túlélést, akkor amikor a legalacsonyabb szinten állnak a szervezet energiatartalékai.

A vadászat zavaró hatásáról tehát megoszlanak a vélemények. Úgy is lehet érvelni, hogy a vadászat zavaró hatása nem játszhat komolyabb szerepet a Nyugat-Palearktiszban élő vízimadarak populációszintjének alakításában, mert számos faj az elmúlt időszakban visszanyerte korábbi létszámát (KALCHREUTER, 1987; ROSE \& SCOTT, 1994). Mások viszont (EBBINGE, 1991) - főleg vadludak esetében - éppenséggel a vadászattal szembeni védelem javuló hatékonyságának tulajdonítják az állománynövekedést. Bármelyik változatnak is van nagyobb súlya, a nemzetközi védelem, a populációk vonulási útvonalának szintjén történő tervszerü gazdálkodás (management) egyezményekre alapuló, összehangolt stratégiai feltételrendszerében lehet a vadászat zavaró hatásait megfelelően kezelni, megoldására kísérletet tenni. Erre a célra jött létre az AEWA, amelynek nemzeti szintü lebontása adhatja meg azt a hozzájárulás-alapot, amelynek mentén Magyarország is hozzáteheti a maga részét a vízivad védelméhez a bölcs hasznosítás fenntartása mellett.

A vadászati szakirodalom tehát egyetért azzal, hogy a vízivad vadászata során arra kell törekednünk, hogy a zavarást a minimumra csökkentsük. Már csak azért is, mert a nem vadászó természet- és madárbarátnak ugyanolyan joga van a meg nem zavart vízimadarak megfigyelésére, mint a vadásznak azok vadászati hasznosítására. Miként lehet a zavarás okozását elkerülni? Nagyobb vadászati nyomásnál, az alábbi módszerek bevezetését ajánlják.

- Vadászati nyugalmi zónák: A récék és még inkább a ludak igen gyorsan megtanulják, hogy hol vannak biztonságban (ún. rezervátumhatás). Jütland nyugati részén a kacsák $90 \%$-a az élőhelyek azon 20\%-án koncentrálódott, ahol nem lehetett rájuk vadászni (MELTOFTE, 1982). Az intenzíven vadászott francia tengerparti területek közül a kacsák zömében ott tartózkodnak - hasonló élőhelytípusok esetében is - ahol vadászati tilalom van (TAMISIER, 1985). Ez a viselkedésminta teszi lehetővé olyan zónák kijelölését, ahol sohasem vadásznak, ahol tehát a madarak zavartalanul tudnak pihenni és táplálékot keresni. Ámde az ilyen refúgiumokat nagyon meggondoltan kell tervezni. Mértékként a vízivad fajok tényleges igényének kell szolgálnia. Az amerikai licenc-rendszerben nyert több évtizedes tapasztalat alapján az egyedi nagy vadászati nyugalmi zónáknál, amelyek eltérő értékü biotópokat ölelnek fel, lényegesen elönyösebb a több kicsi, mintegy 50 hektáros kiterjedésü zóna. A zónák akkor eléggé nagyok, ha a madarak a környéken folytatott vadászatok idején már nem zavartatják magukat. Az egyébként nagyon óvatos madarak a védett területeken sokkal kisebb távolságban türik meg az embert (FIGLEY \& VANDRUFF, 1982) - amit egyébként NyugatEurópában is meg lehet figyelni, amikor télen a vadkacsák a városi tavakon jelennek meg. A nyugalmi zónák között olyan távolságnak kell lenni, amekkorát a napi aktivitásuk során meg tudnak tenni. Ennél 75 km-t tekintik a felső határnak. A több kisebb nyugalmi zóna legalábbis amerikai viszonyok között - elönyösebb volt, mint egyes, egymástól messze fekvő nagyok. Hazai viszonyok között az 1993-ban bevezetett kíméleti területek hálózata - immár a koncentrált hazai vizes élőhelyekhez igazodva - ugyanezt a célt szolgálja (FARAGÓ, 1997b; 1997c).

- Pontosan meghatározott lóállások: Ahol sok vadász vadászik egy területen, a zavarást jelentősen csökkenteni lehet az által, ha csak meghatározott lőállásokból lőnek. A madarak ezt is hamar megtanulják és a vadászatok napjain is kihasználják a sörétlövés hatótávolságai közötti köztes tereket. A nem vadászott fajok, mint a gázlómadarak gyakran koncentrálódnak 
az állások közvetlen közelében. Ezekhez csak pontosan meghatározott utakon szabad odamenni.

- Kímélö napok: A vizes élőhelyeknek, mint a vízimadarak táplálékkereső és pihenő helyeként való hasznosítása és azok vadászata közötti további kompromisszumos lehetőség az, hogy csak bizonyos napokon vadásznak (pl. a hét három, vagy négy napján a vadászoknak otthon kell maradniuk, a terület olyankor egyedül a vízimadaraké. Hasonló megfontolások alapján volt tilos 10 és 15 óra között ludakra vadászni Hollandia és Németország egyes területein. Ebben az időben a libacsapatok zavartalanul táplálkozhatnak.

- Vadászati szünet fagyperiódusokban: a vadászatnak hosszabban tartó szigorú fagyok idején teljesen szünetelni kellene, mégpedig több okból:

- A vizek egyre jobban eljegesednek, a madarak egyre kisebb területre zsúfolódnak össze, táplálékhiány léphet fel, miközben az energiát felemésztő hideg nagyobb táplálékfelvételre kényszerít.

- Ilyen körülmények között a vadászat által keltett zavar miatti többszöri felrepülés az alkalmas pihenőterületek hiábavaló keresésével összekötve valóban negatív energiamérleghez és esetleg a madárpusztulásához vezethet.

- A táplálékhiány következtében legyengült madarak a kicsi és még megmaradt életterekben szükségképpen a vadászok könnyebb zsákmányává válnak. Ezáltal fennáll a túlhasznosítás veszélye.

- A térbeli korlátozásokat nagyobb tavakon, tórendszereken alkalmazzák, mert itt „vadkamrákat”, nem vadászott egységeket lehet kialakítani. Ezek olyan helyek, ahova a vízivad a tórendszeren belül visszavonulhat, így a vadászati nyomás okozta zavarást, nem kell elvándorlással kivédenie. Ez a módszer természetesen csak megfelelően ésszerű vadászati nyomás mellett müködik, azaz ha egy vadásznap után több olyan vadászatmentes nap következik, amikor a madarak a kíméleti területről visszaszokhatnak a tórendszer teljes területére.

- A térbeli és időbeni kombinált korlátozási módszer lényege, hogy a tórendszer területét három vagy több részre osztják, $\mathrm{s}$ azon belül vagy kétéves váltó rendszerü hasznosítást alkalmaznak, vagy három éves „forgó” szerint vadásznak.

A kétéves váltó rendszerü gazdálkodásban a tórendszert két - adottságaiban és a vízivad előfordulása, mozgása alapján - egyenlő nagyságú részre osztják. A vadászati hasznosítási ciklus két éves, egyik évben az egyik, másik évben a másik egység tavait vadásszák. Az egységek közel vannak egymáshoz, a madarak könnyen átszállhatnak a megkímélt tavakra. A közelség miatt a kímélt tavakon is érződik a zavarás, de ez nem olyan mérvü, amely a kacsák eltünését eredményezné. A közelség, a kezelhető méret miatt a vadászat is könnyen szervezhető, bizonyos mértékig a madarakat még ,irányítani” is lehet. Feltétlenül betartandó a kíméleti terület zavartalansága, hiszen ez a rendszer müködésének záloga. A hároméves ,forgó” rendszerü gazdálkodásban a halastavon három területrészt alakítanak ki. A három egységből mindig csak egyen folyik vadászat, a másik kettő „,pihen”, vadkamraként müködik. Ez gyakorlatilag azt jelenti, hogy egy-egy területre - mint vadászati egységre - 3 évenként kerül sor, s két évig lát el vadkamra feladatot. A kamrázó területek vadmegtartó képessége igen magas, ugyanakkor a madarak kijárnak más tóegységekre táplálkozni, s így a vadászatot lehetővé teszik.

Nem kétséges tehát, hogy a vízivadas területek kímélete a populáció egészére jótékony hatással van, ami a terítéknagyságban is realizálható. Ennek eléréséhez a kezelő - olykor vadgazdálkodási megfontolásokból-, korlátozásokat kényszerül bevezetni. 


\section{ANYAG ÉS MÓDSZER}

A vízivad, benne a vadlúdállomány felmérések helyeinek (1. térkép) és módszerei vonatkozásában hivatkozunk az 1984-től folyamatosan végzett MAGYAR VADLÚD MONITORING eddigi közléseire (FARAGÓ, 1995; 1996; FARAGÓ \& JÁNOSKA, 1996a, 1996b; FARAGÓ, 1998a; 1999a; 2001a; 2002a; 2002b; FARAGÓ \& GOSZTONYI, 2003a; FARAGÓ, 2005a; 2006a; 2007a; 2007c; 2008a; 2010a; 2010c; 2011a; 2011c; 2012a; 2014a; 2015a; 2016a; FARAGÓ, 2017a). Fentiek alapján mind a régiók adatai, mind az országosan összesített adatok kinyerhetők.

Egyéb vízivadfajok felmérései eredményeinek vonatkozásában pedig az 1996-tól folyamatosan végzett MAGYAR VÍZIVAD MONITORING eddigi közléseire hivatkozunk (FARAGÓ, 1998b; 1999b; 2001b; FARAGÓ \& GOSZTONYI, 2002; FARAGÓ, 2002c; FARAGÓ \& GOSZTONYI, 2003b; FARAGÓ, 2005b; 2006b; 2007b; 2007d; 2008b; 2010b; 2010d; 2011b; 2011d; 2012b; 2014b; 2015b; 2016b).

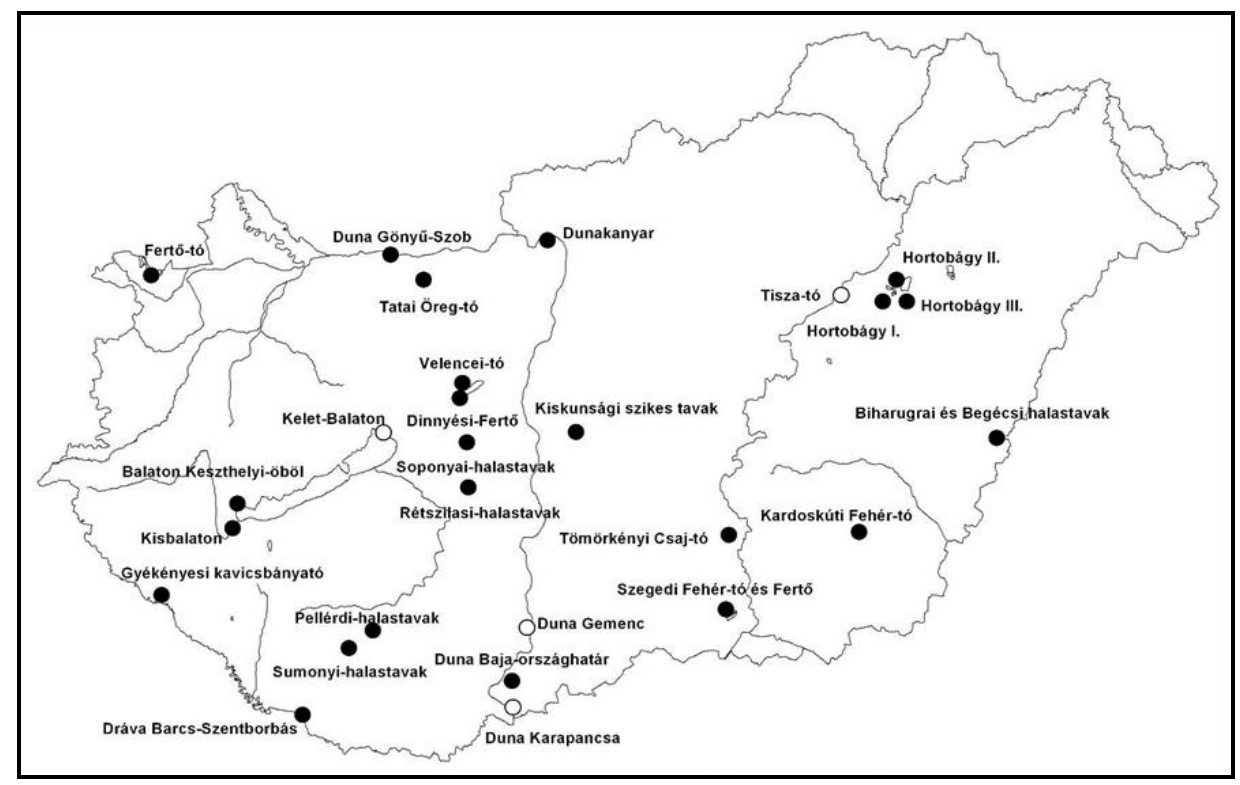

1. térkép: A MAGYAR VÍZIVAD MONITORING standardizált megfigyelési területei Map 1: Standardized observation sites of HUNGARIAN WATERFOWL MONITORING

A MAGYAR VÍZIVAd Monitoring adatbázisából képesek vagyunk előállítani az egyes fajok hosszú távú dinamikáját, trendjét és az fenológiáját jellemző diagramokat. Mindezt regionális és lokális szinten is elvégezzük. Az adatbázis alapján fajonként megadhatók a szezononkénti tér-idő mintázatok térképei is.

A terítékekre vonatkozó alapadatok az ORSZÁGOS VADGAZDÁLKODÁSI ADATTÁR adatbázisából származnak (CSÁNYI 1996; 1998; 1999; 2000; 2001; 2002; 2003; 2004; 2005; CSÁNYI et al., 2006; 2007; 2008; 2009; 2010; 2012a; 2012b; 2013; 2014; 2015; 2016).

A vadgazdálkodók éves vadgazdálkodási jelentései ugyanis tartalmazzák:

- a vadászható vízivad fajok éves terítékét faji bontásban

- a kibocsátott tőkés réce mennyiségét

- a kibocsátott tőkés récéből elejtett mennyiséget

- a vízivad tenyésztésére vonatkozó információkat

A feldolgozás során megyei és országos összesítőket készítenek, s mód van regionális feldolgozásra is feldolgozásra is. 


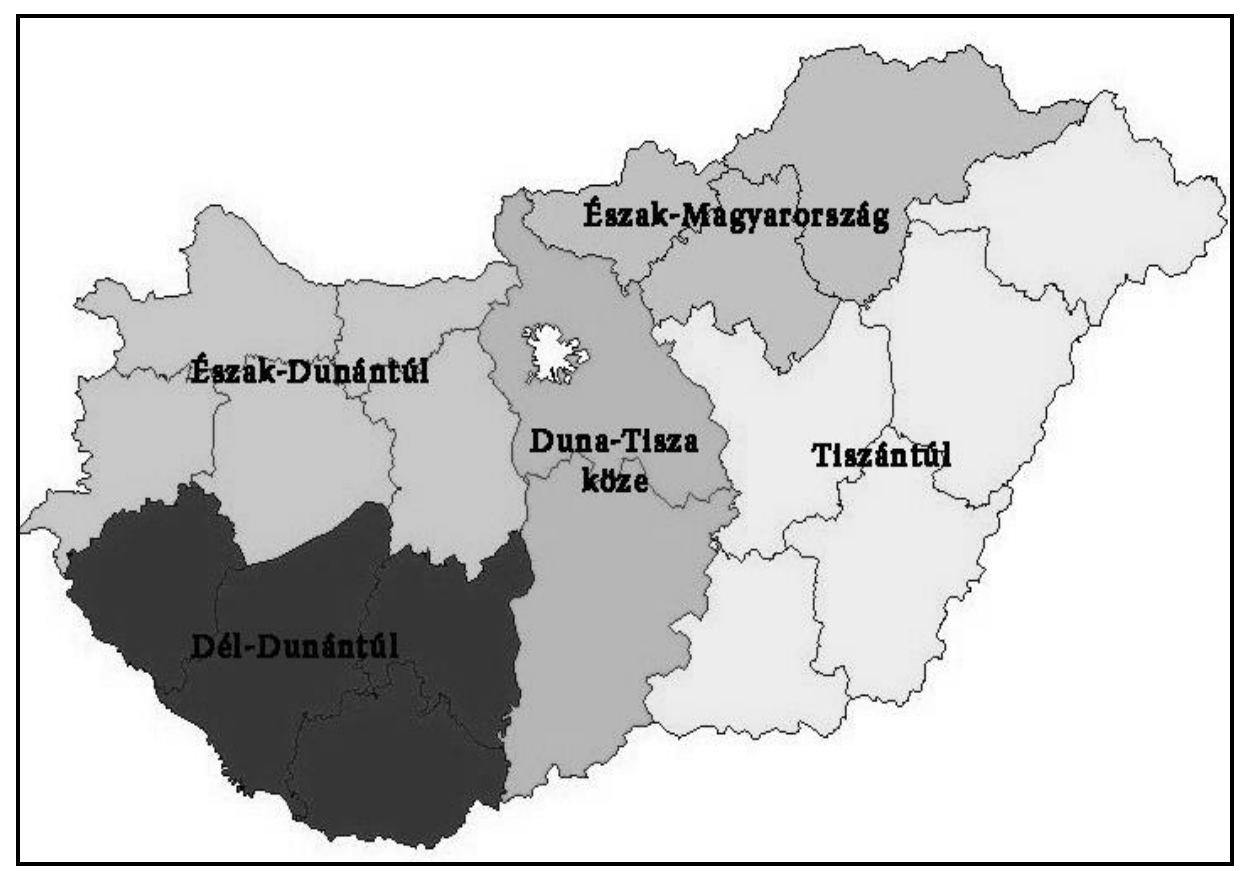

2. térkép: Magyarország öko-régiói

Map 2: Eco-regions of Hungary

A teríték és hasznosítás vizsgálatok elsődleges alapja tehát az ORSZÁGOS VADGAZDÁLKODÁSI ADATTÁR terítékadatainak elemzése. Az egyes vadászati évek vadgazdálkodási jelentései alapján alfabetikus megyei felsorolásban, de vadgazdálkodási egységenként kigyüjtésre kerültek a vadászható vízivad fajok, azaz a vetési lúd (Anser fabalis), a nagy lilik (Anser albifrons), a nyári lúd (Anser anser), a tőkés réce (Anas platyrhynchos), a böjti réce (Anas querquedula), a csörgöréce (Anas crecca), a barátréce (Aythya ferina), a kerceréce (Bucephala clangula) és a szárcsa (Fulica atra) terítékadatai. A vízivad teríték megyei és országos összesítése mellett a feldolgozás során ökológiailag is értelmezhető régiókra osztottuk fel az országot (2. térkép):

- Észak-Dunántúl: Győr-Moson-Sopron, Komárom-Esztergom, Vas, Veszprém és Fejér megyék

- Dél-Dunántúl: Zala, Somogy, Tolna, Baranya megyék

- Észak-Magyarország: Nógrád, Heves és Borsod-Abaúj-Zemplén megyék

- Duna-Tisza-köze: Pest és Bács-Kiskun megyék

- Tiszántúl: Szabolcs-Szatmár-Bereg, Hajdú-Bihar, Jász-Nagykun-Szolnok, Békés és Csongrád megyék

Az értékelések során megállapítottuk:

- a teríték dinamikája és annak trendje régiónként és Magyarország egészén,

- a vadászható vízivad fajok terítékének régiók közötti megoszlását

- külön-külön a vadlúd fajok, illetöleg a réce fajok + szárcsa dominanciáját az egyes régiókban, azaz a teríték términtázatára utaló legfontosabb jellemzőket.

a vízivad fajok számlált és terítékre hozott mennyisége közötti viszony

- regresszió-számítás alapján

- hasznosítási arány alapján 


\section{A VÍZIVAD VADÁSZAT JOGI FELTÉTELEI MAGYARORSZÁGON}

\subsection{A MAGYAR VÍZIVAD VADÁSZAT JOGI SZABÁLYOZÁSÁNAK TÖRTÉNETI ÁTTEKINTÉSE}

A vízivad vadászat jogi szabályozása évszázados múltra tekint vissza Magyarországon, amelyet az alábbiakban tekinthetünk át (STERBETZ, 1972; OROSZI, 1996; FARAGÓ, 1982a; 1982b; 1991a; 2003c; 2004b).

Az 1872. és 1883. évi vadászati törvények tulajdonképpen minden vízivad faj elejtését lehetővé tették, sőt „Tiltott időszakban is szabad vadászni a seregekben vonuló vadludakra és vadkacsákra.."- írta az 1872. évi VI. tc. 13-14§.

A földmüvelésügyi miniszter 23.470/1912. FM számú rendelete rendelkezett „.. a bibic-, vadlúd- és vadkacsatojások jogosulatlan elszedésének, eladásának és kiköltésének megakadályozásáról".

További szigorítást jelentett az 1925. évi tilalmi rendelet, amikor a vízivad vadászatát - a korábbi bizonytalanságot megszüntetve - április 16.-június 30. közötti időszak megadásával tiltották meg. Ugyanakkor bár továbbra is egész évben engedték a seregekben vonuló vadludakra és récékre a vadászatot, a nyári lúd és a tőkés réce vadászatát az általános időintervallumhoz képest tovább szigorították, védelmi idejüket - a fészkelő populációkat kímélendő - március 1.-június 30. közötti időszakban szabták meg, azaz július 1.-február 28. között voltak vadászhatók.

\subsubsection{A vadlúdvadászat szabályozásának alakulása}

1948-ig minden vadlúd faj, 1950-ig minden récefaj vadászható volt Magyarországon, akkor azonban védetté nyilvánították a nyári ludat (Anser anser), 1950-ben pedig a kékcsőrü récét (Oxyura leucocephala). Ugyanettől az évtől azonban a halastavaknál egész évben megengedték a szürke gém (Ardea cinerea) és a szárcsa (Fulica atra) vadászatát.

Az 1954. évi madárvédelmi rendelet oltalmat adott az addig lőhető vöcsökféléknek, fokozottan védett lett a már védett kékcsőrü réce és nyári lúd.

Az 1948/1949-es vadászati idénytől lehet faji szintü vadászati szabályozásról beszélni. A vadludak közül már csak a vetési lúdra (Anser fabalis), a nagy lilikre (Anser albifrons) és a kis lilikre (Anser erythropus) lehetett vadászni szeptember 1.-április 15. között. E fajok folyamatos állománycsökkenése miatt azonban 1968-tól jelentősen lerövidült - szeptember 1.-december 31. - a vadlúdvadászati idény, sőt 1982-től védelem alá került a kis lilik.

Ezt követően az 1980-as években a vetési lúdra és a nagy lilikre megállapított vadászati idény október 1.-január 15. közötti (107 nap), majd október 1.-január 31. közötti (123 nap) volt, végül 1990-ben ismét visszaállították a 107 napos vadászidény hosszat.

A 8/1993. FM rendelet a nagy lilik vadászatát - vadfaj státusa fenntartása mellett szüneteltette (nem adott meg rá vadászati idényt), illetve károkozása esetén egyedi engedélykiadáshoz kötötte, a vetési lúd esetében pedig visszaállt a 122 napos - október 1.január 31. közötti - vadászati idény. Új szabályozási módot, a napi terítékkorlátozást is bevezette a rendelet, azaz vadászonként naponta 4 pd volt elejthető vadludakból. További pontosító intézkedések az alábbiak voltak: a libákat csak sörétes fegyverrel lehetett elejteni, s csak a repülő madarakra lehetett lövést tenni. Tilos volt elektroakusztikai eszközök (pl. magnetofon) alkalmazása, illetve csalimadarak alkalmazása. Tilos voltaz éjszakai vadászat, vadászatot 1 órával napfelkelte előtt lehetett megkezdeni, és be kellett fejezni napnyugta után 1 órával. Tilos volt vadászni motorcsónakból.

A 30/1997 (IV.30.) FM rendelet szerint a vetési lúd és a nagy lilik esetében a vadászati idények október 1. - január 1. közöttiek voltak, de nagy lilik esetében azt csak kérelemre, a vadászati hatóság által meghatározott időben és mennyiségben lehetett elejteni. 
A 79/2004 (V.4.) FVM sz. rendelet is eltérően szabályozta a két vadászható vadlúd faj vadászatát. A vetési lúd vadászidénye általánosságban nem változott: október 1.-január 31. közötti (123 nap), de Hajdú-Bihar, Békés és Csongrád megye teljes közigazgatási területén, valamint Jász-Nagykun-Szolnok megye tiszántúli részén csak december 1.- január 31. között (62 nap) lehetett rájuk vadászni. Mindennek elfogadható indoka a globálisan veszélyeztetett, a Tiszántúlon megjelenő kis lilik (Anser erythropus) kötelező kímélete, a téves lelövések pótolhatatlan károkozásának és az abból fakadó konfliktusoknak a megelözése. A nagy lilik külön engedélyhez kötött vadászata megszünt, vadászidénye október 1.-január 31. közötti (123 nap). A kis lilik védelme szempontjából - hasonlóan a vetési lúdnál elmondottakhoz helyi vadászati tilalomhosszabbítás történt, amelynek értelmében Hajdú-Bihar, Békés és Csongrád megye teljes közigazgatási területén, Jász-Nagykun-Szolnok megye tiszántúli területén csak december 1.- január 31. között (62 nap) tart a vadászata. Változatlan a napi terítékkorlátozás megszorítása: mind vetési lúdból, mind nagy lilikből naponta és személyenként összesen ugyancsak legfeljebb 4 példány ejthető el.

A 7/2010 (II.2.) FVM rendelet 5. melléklete szerint a vetési lúd és a nagy lilik október 1. - január 31. között (123 nap) volt vadászható. További értelmező megjegyzések az alábbiak voltak: „27/A. § (1) Az 5. számú melléklet II. részében felsorolt vízivad fészkelése és vonulása szempontjából nemzetközi jelentőségü és hazai kiemelt jelentőségü vízi élőhelyeken a vadászati hatóság szabályozta a vízivad vadászat rendjét. Ebben szabályozta a vízivad vadászatának helyét, módját, idejét, gyakoriságát.

(2) A vetési lúd és a nagylilik vadászati idénye Hajdú-Bihar, Békés és Csongrád megye teljes közigazgatási területén, valamint Jász-Nagykun-Szolnok megye Tiszántúli területén december 1-jén kezdődött és január 31-ig tartott. Vetési lúdból és nagy lilikből naponta, személyenként összesen legfeljebb 4 darab volt elejthető.

A 72/2012 (VII.24.) VM rendelet 1. melléklete további változásokat hozott. A vetési lúd és a nagy lilik október 1-január 31. közötti vadászata (123 nap) mellett ugyanezen idényben engedélyezte a kanadai lúd (Branta canadensis) és a nílusi lúd (Alopochen aegyptiaca), valamint október 1-december 31. között (92 nap) a nyári lúd (Anser anser) vadászatát. A nyári lúdból, vetési lúdból és nagy lilikből naponta, személyenként összesen legfeljebb hat darab volt elejthető, amelyből a nyári ludak száma nem lehetett több kettőnél. A vetési lúd és a nagy lilik vadászati idénye Hajdú-Bihar, Békés és Csongrád megye teljes közigazgatási területén, valamint Jász-Nagykun-Szolnok megye tiszántúli területén december 1-jén kezdődött és január 31-ig tartott. A nyári lúd vadászati idénye Hajdú-Bihar megye teljes közigazgatási területén, valamint Jász-Nagykun-Szolnok megye tiszántúli területén szintén december 1-jén kezdődött és december 31-éig (31 nap) tartott.

A 24/2017. (V. 17.) FM rendelet a vad védelméröl, a vadgazdálkodásról, valamint a vadászatról szóló 1996. évi LV. törvény végrehajtásának szabályairól szóló 79/2004. (V. 4.) FVM rendelet módosításáról, sem a vadászati idényekben, sem a teríték limitekben, sem a tilalmazott regionális szabályozások, sem pedig a kíméleti területek vonatkozásában változást nem hozott a korábbi szabályozásokhoz képest.

\subsubsection{A vadrécevadászat szabályozásának alakulása}

A vadrécék vadászata az 1925. évi tilalmi rendelet szerint - mint már írtuk - előbb július 1.-én, majd július 15-én kezdödött és február 28-ig tartott.

1958-ban fordulat állt be a szabályozásban, mert a vadászati idényt augusztus 1.december 31. között - 153 nap - állapították meg. Igaz a korlátozás nem terjedt ki a rizstelepekre, ahol kezdetben az egész év folyamán lehetett vadászni rájuk (dúvadnak számítottak ott). 1961-ben aztán ott is július 1.-én kezdődött a vadászati idény, majd 1963-tól megszünt a vadrécevadászatok rizstelepeken való eltérő szabályozása. 
A vízivad további fogyása miatt a 30/1970. (XII.24) MÉM. sz. rendelet már csak 5 récefaj vadászatát engedték meg, ezek a tőkés réce (Anas platyrhynchos), a csörgö réce (Anas crecca), a böjti réce (Anas querquedula), a fütyülöréce (Anas penelope) és a barátréce (Aythya ferina) voltak, a vadászati idény pedig augusztus 1.-január 15.-ig - 168 nap - tartott.

A vadrécék vadászata 1973-ban augusztus 15-én kezdődött, amit később visszaállítottak augusztus 1.-re, de a jogszabály tartalmazta azt a megszorítást, hogy csak húzáson - tehát röpképes egyedekre - való vadászata volt engedélyezett. Ezt követően elöbb meghosszabbították az idényt január 31.-ig, majd 1990-töl egy hónappal rövidítették úgy, hogy 15 nappal később kezdődött és 16 nappal korábban fejeződött be, azaz augusztus 15.január 15. közötti 154 nap volt. Augusztus folyamán változatlanul érvényben volt a húzáson (tehát röpképes egyedre) való vadászat elöírása.

A 8/1993. (I.30.) FM sz. rendelet kivette a vadászható fajok köréből a fütyülő récét (Anas penelope) és vadfaj kategóriába emelte a kercerécét (Bucephala clangula), s a vadászati idényt augusztus 15.-január 31. időintervallumban, 170 napban határozta meg.

A 79/2004 (V.4.) FVM sz. rendelet újabb változásokat hozott, a szabályozás történetében először faji szinten eltérő idényekkel és rendelkezésekkel. A tőkés réce vadászati idénye szeptember 1.-január 31. közötti 153 nap. A későbbi kezdés biztosította a kifejletlen fiatalok, azaz költő állományunk, továbbá a vedlésben lévő „lohos” példányok védelmét, a vadászat pedig valóban a repülőképes példányokat érintette. Változatlan lehetőségként a tenyésztett tőkés réce napi terítékkorlátozás nélkül, tilalmi időben is lőhető volt, ami a természetes populációk védelmét is szolgálta. A böjti réce azidőtájt Európában sebezhető faj volt, a magyar fészkelő és vonuló állomány stabilnak volt tekinthető. Annak ellenére, hogy hazai terítéke nem volt számottevő, vadászható faj státusa fenntartása mellett, vadvédelmi okokból - csatlakozva a védelmét biztosító európai törekvésekhez - egész éves vadászati tilalom alá vonták. A csörgö réce vadászati idénye ugyancsak szeptember 1.- január 31. közötti 153 nap volt, hasonlóan a tőkés récéhez. A barátréce cigányrécével való összetéveszthetősége (és részben átfedő élőhely igényük) miatt - ami utóbbi fajt veszélyeztette, nemkülönben jogi konfliktusok forrása volt - vadászidénye később, október 1.-én kezdődött, de változatlanul január 31.-ig, 123 napig tartott. Mivel a kerceréce vonuló állományai október végén jelennek meg hazánkban, azért a korábbi augusztus 1.-i idénykezdés értelmetlen volt. Valós vadászati lehetőségeinket visszatükrözte az október 1.január 31. közötti, 123 napos vadászidény. Valamennyi fajra érvényes volt a naponta, személyenként összesen legfeljebb 8 példány elejtését lehetővé tevő terítékkorlátozás.

A 7/2010 (II.2.) FVM rendelet 3. melléklete szerint változatlanul a tőkés réce és a csörgö réce szeptember 1.-január 31. között, a kerceréce október 1.-január 31. volt vadászható.

A 72/2012. (VII. 24.) VM rendelet szerint récefélék közül már csak a tőkés récére lehetett vadászni augusztus 15. -január 31. között, de augusztus 15-től augusztus 31-ig kizárólag húzáson és a vízparttól - azaz a vízzel borított terület és a szárazföld találkozásától - számított 50 méteren kívül volt szabad vadászni. Tökés récéből naponta, személyenként összesen legfeljebb nyolc darab volt elejthető. Tenyésztett tőkés réce tilalmi időben is napi terítékkorlátozás nélkül lőhető volt.

A 24/2017. (V. 17.) FM rendelet a vad védelméröl, a vadgazdálkodásról, valamint a vadászatról szóló 1996. évi LV. törvény végrehajtásának szabályairól szóló 79/2004. (V. 4.) FVM rendelet módosításáról a tőkés réce vadászat szempontjából sem a vadászati idényben, sem a teríték limitben változást nem hozott a korábbi szabályozásokhoz képest. 


\subsubsection{A szárcsavadászat szabályozásának alakulása}

A szárcsa vadászatának szabályozása mindig egybeesett a tőkés récére vonatkozó előírásokkal, már csak azért is, mert Magyarországon a tőkés réce mellett a leggyakoribb faj. Mivel fészkelö és vonuló állománya stabil volt, azért a 79/2004 (V.4.) FVM sz. rendeletben elöírtak szerint, vadászati idénye - a tőkés récénél megfogalmazott indokokkal - szeptember 1.-január 31. közöttire változott, azaz 153 nap volt. Naponta, személyenként összesen legfeljebb 8 szárcsa volt elejthető.

Ezt a vadászidényt megtartotta a 7/2010 (II.2.) FVM rendelet, a 72/2012. (VII. 24.) $V M$ rendelet és a 24/2017. (V. 17.) FM rendelet is.

\subsubsection{A vízivad kíméleti területek rendszerének bevezetése és alakulása}

A 8/1993. FM rendelet megalkotása során elsőként kerültek egy magyar vadászati jogszabályba az általunk javasolt vadvédelmi szempontból kiemelt területek, amelyek az 5. sz. Vadászati idények melléklet III. pontjában felsorolást nyertek. Ezek az alábbiak voltak:

1. Fertő-tó

2. Balaton egész felülete

3. Kisbalaton régi tó, új tározók

4. Velencei-tó/Dinnyési Fertő

5. Tatai Öreg-tó

6. Rétszilasi halastavak

7. Hortobágyi Nemzeti Park valamennyi Ramsari területe

8. Biharugra-begécsi halastavak, a Biharugrai-rét és Szőr-rét

9. Kardoskúti Fehér-tó

10. Szegedi Fehér-tó, valamint a Pusztaszeri Tájvédelmi Körzet valamennyi Ramsari területe (Csaj-tó és a Büdös szék)

Az első lépcsőben a vízivad vadászattól érintetlen területté lett szinte minden fontos vonulóhely.

Kimaradt viszont a listáról a Hortobágyi halastavak zöme, a Kiskunsági szikes tavak Ramsari-terület, a Tisza-tó, a Dunai zátonyok, a Sumonyi és Pellérdi halastavak, illetve a Soponyai/Táci halastavak. Ezeket a következő jogalkotási lépcsőben kellett pótolni.

Bekerült viszont már a listába a Hortobágyi Nemzeti Park valamennyi Ramsari területe (Zám, Pentezug, Angyalháza puszták, Hortobágyi halastó, Jusztus-mocsár, Hagymás lapos és a Kunkápolnási mocsár), a Pusztaszeri Tájvédelmi Körzet valamennyi Ramsari területe (Csaj-tó és a Büdös szék a Szegedi Fehér-tón kívül), a Biharugrai-rét és Szőr-rét a Biharugra/Begécsi halastavakon felül.

„A felsorolt területek védözónáit a hivatal 1993. augusztus 15-ig jelöli ki és teszi közzé. A területileg illetékes természetvédelmi hatóság szakhatóságként müködik közre."

A 8/1993. FM. sz. rendelet VII. fejezet 31.§ (6) bekezdése szerint "’... a vizivad fészkelési és vonulási szempontból jelentős élőhelyeire vonatkozó tilalmakról szóló rendelkezéseit 1993. augusztus 15-töl kell alkalmazni."

A 30/1997 (IV.30.) FM rendelet meghatározta (3. melléklet) a kiemelt jelentőségü vízi élőhelyeket. A vízivad fészkelési és vonulási szempontból kiemelt jelentőségü vízi élőhelyeken a vadászati hatóság - védett természeti területet érintően a természetvédelmi hatóság szakhatósági hozzájárulásával - szabályozta a vízivad vadászat rendjét. Ebben meghatározta a vízivad vadászatának helyét, módját, idejét, gyakoriságát és a vadászható vadfajokat. E rendelet 3. mellékletében felsorolt „Vizivad fészkelési és vonulási szempontból kiemelt, nemzetközileg is jelentös vízi élöhelyek" sora az alábbi volt: 
1. Fertö-Hanság Nemzeti Park területéből a Fertö-tavi rész

2. Tatai Öreg-tó TT

3. Velencei Madárrezervátum TT és a Dinnyési Fertő TT

4. Sárvíz-völgye TK

5. Pacsmagi-tavak TT

6. A Balaton-felvidéki Nemzeti Park területéből a Kisbalaton régi és új tározók

7. Balaton

8. Duna-Dráva Nemzeti Park területéből a Gemenci és a Béda-karapancsai rész

9. Ócsai TK

10. Kiskunsági Nemzeti Park területéből a Kiskunsági szikes tavak, az Izsáki Kolon-tó, az Orgoványi rétek és a Tiszaalpári rét

11. Pusztaszeri TK-ból a szegedi Fehér-tó, a Tisza labodári és saséri területe, a Csaj-tó, a Baksi nagylegelö és a Büdösszék-tó

12. Péteri-tavi Madárrezervátum TT

13. A Körös-Maros Nemzeti Park területéböl a Kardoskúti Fehér-tó, a Biharugai- és Begécsi-halastavak és a Szö-rét

14. Hortobágyi Nemzeti Park teljes területe

15. Rácalmástól az országhatárig valamennyi Duna zátonyon

16. Vértesi TK-ból a Csíkvarsai-rét

17. Pellérdi-halastavak

18. Sumonyi-halastavak

19. Baláta tó TT

20. Boronka-melléki TK

21. Borsodi-Mezőség TK

22. Csondrádbokrosi Sós-tó

23. Gátéri Fehér-tó

24. Háros-szigeti Ártéri Erdő TT

25. Hevesi Füves Puszták TK

26. Kecskeri puszta TT

27. Kesznyéteni TK

28. Körös-Maros Nemzeti Park területéböl a cserebökényi-puszták, a pitvarosi-puszták, szabadkígyósi-puszták

29. Közép-tiszai TK

30. Nagybereki Fehér-víz TT

31. Sárosfői-halastavak TT

32. Sárréti TK

33. Szaporcai Ó-Dráva-meder TT

34. Szatmár-Beregi TK

35. Szigetközi TK

36. Tiszatelek-Tiszaberceli Ártér TT

37. Tiszavasvári Fehér-szik TT

38. Tiszadobi-ártér TT

39. Tiszadorogmai Göbe-erdő TT

40. Tokaj-Bodrogzugi TK

A 79/2004 (V.4.) FVM sz. rendelet 5. mellékletében felsorolt „, Vizivad fészkelési és vonulási szempontból nemzetközi jelentőségü, illetve hazai kiemelt jelentöségü vizes élőhelyek" sora az alábbi volt:

\section{VÍZIVAD FÉSZKELÉSI ÉS VONULÁSI SZEMPONTBÓL NEMZETKÖZI JELENTŐSÉGÜ VÍZI ÉLÖHELYEK}

1. Fertő $\square$ Hanság Nemzeti Park területéből a Fertő-tavi rész

2. Tatai Öreg-tó TT

3. Velencei Madárrezervátum TT és a Dinnyési Fertő TT

4. Pacsmagi-tavak TT

5. A Balaton-felvidéki Nemzeti Park területéből a Kisbalaton régi és új tározók

6. Balaton

7. Duna $\square$ Dráva Nemzeti Park területéből a Gemenci és a Béda-karapancsai rész

8. Ócsai TK 
9. Kiskunsági Nemzeti Park területéből a Kiskunsági szikes tavak, az Izsáki Kolon-tó, az Orgoványi rétek és a Tiszaalpári rét

10. Pusztaszeri TK-ból a szegedi Fehér-tó, a Tisza labodári és saséri területe, a Csaj-tó, a Baksi nagylegelő és a Büdösszék-tó, Mártély

11. A Körös-Maros Nemzeti Park területéböl a Kardoskúti Fehér-tó, a Biharugrai- és Begécsi-halastavak és a Szö-rét

12. Hortobágyi Nemzeti Park

13. Csongrád-bokrosi Sós-tó

14. Szaporcai Ó-Dráva meder TT

15. Felső-Tisza (a Tisza hullámtere Tokajtól az országhatárig)

16. Tokaj-Bodrogzugi TK

17. Rétszilas

\section{VÍZIVAD FÉSZKELÉSI ÉS VONULÁSI SZEMPONTBÓL HAZAI KIEMELT JELENTŐSÉGÜ VÍZI ÉLÖHELYEK}

1. Sárvíz-völgye TK

2. Péter-tavi Madárrezervátum TT

3. Rácalmástól az országhatárig valamennyi Duna-zátony területe

4. Vértesi TK-ból a Csíkvarsai-rét

5. Pellérdi-halastavak

6. Sumonyi-halastavak

7. Baláta-tó TT

8. Boronka-melléki TK

9. Borsodi-Mezőség TK

10. Gátéri Fehér-tó

11. Hevesi Füves Puszták TK

12. Kecskeri puszta TT

13. Kesznyéteni TK

14. Körös-Maros Nemzeti Park területéböl a cserebökényi-puszták a pitvarosi-puszták, szabadkígyósi-puszták

15. Közép-tiszai TK

16. Nagybereki Fehér-víz TT

17. Sárosföi-halastavak TT

18. Sárréti TK

19. Szatmár-Beregi TK

20. Szigetközi TK

21. Tiszatelek-Tiszaberceli Ártér TT

22. Tiszavasvári Fehér-szik TT

23. Tiszadorogmai Göbe-erdő TT

Az 59. § (1) szerint az 5. számú melléklet II. részében felsorolt nemzetközi jelentőségü vízi élöhelyeken (lásd elöbb) 2005. augusztus 15-töl az ólomsörét használata vízivad vadászat során tilos lett. A felsorolt vízi élőhelyek határain vízivad vadászat oly módon folytatható, hogy a tilalommal érintett területre a kilött ólomsörét ne hulljon a vissza.

A 7/2010 (II.2.) FVM rendelet értelmező megjegyzései az alábbiak voltak:

„27/A. § (1) Az 5. számú melléklet II. részében felsorolt vízivad fészkelése és vonulása szempontjából nemzetközi jelentőségü és hazai kiemelt jelentőségü vízi élőhelyeken a vadászati hatóság szabályozza a vízivad vadászat rendjét. Ebben szabályozza a vízivad vadászatának helyét, módját, idejét, gyakoriságát. A vízivad kíméleti területek pedig az alábbiak voltak:

II.

\section{VÍZIVAD FÉSZKELÉSI ÉS VONULÁSI SZEMPONTBÓL NEMZETKÖZI JELENTŐSÉGŰ VÍZI ÉLŐHELYEK}

1. Fertő-Hanság Nemzeti Park területéből a Fertő tavi rész

2. Tatai Öreg-tó Ramsari terület és bővítése 
3. Velencei Madárrezervátum TT és a Dinnyési Fertő TT

4. Pacsmagi-tavak TT

5. A Balaton-felvidéki Nemzeti Park területéből a Kisbalaton régi és új tározók

6. Balaton

7. Duna-Dráva Nemzeti Park területéből a Gemenci és a Béda-karapancsai rész

8. Ócsai TK

9. Kiskunsági Nemzeti Park területéből a Kiskunsági szikes tavak, az Izsáki Kolon-tó, az Orgoványi rétek és a Tiszaalpári rét

10. Pusztaszeri TK-ból a szegedi Fehér-tó, a Tisza labodári és saséri területe, a Csaj-tó, a Baksi nagylegelő és a Büdösszék-tó, Mártély

11. A Körös-Maros Nemzeti Park területéböl a Kardoskúti Fehér-tó, a Biharugai- és Begécsi-halastavak és a Szö-rét

12. Hortobágyi Nemzeti Park

13. Csongrád-bokrosi Sós-tó

14. Szaporcai Ó-Dráva meder TT

15. Felső-Tisza (a Tisza hullámtere Tokajtól az országhatárig)

16. Tokaj-Bodrogzugi TK

17. Rétszilas

18. Ipoly-völgy

19. Böddi-szék

20. Felsö-Kiskunsági szikes puszták Ramsari terület

21. Nyirkai-Hany Ramsari terület

22. Montág-puszta Ramsari terület

VÍZIVAD FÉSZKELÉSI ÉS VONULÁSI SZEMPONTBÓL HAZAI KIEMELT JELENTİSÉGŐ VÍZI ÉLÖHELYEK

1. Sárvíz-völgye TK

2. Péter-tavi Madárrezervátum TT

3. Rácalmástól az országhatárig valamennyi Duna-zátony területe

4. Vértesi TK-ból a Csíkvarsai-rét

5. Pellérdi-halastavak

6. Sumonyi-halastavak

7. Baláta-tó TT

8. Boronka-melléki TK

9. Borsodi-Mezıség TK

10. Gátéri Fehér-tó

11. Hevesi Füves Puszták TK

12. Kecskeri puszta TT

13. Kesznyéteni TK

14. Körös-Maros Nemzeti Park területéből a cserebökényi-puszták a pitvarosi-puszták, szabadkígyósi-puszták

15. Közép-tiszai TK

16. Nagybereki Fehér-víz TT

17. Sárosföi-halastavak TT

18. Sárréti TK

19. Szatmár-Beregi TK

20. Szigetközi TK

21. Tiszatelek-Tiszaberceli Ártér TT

22. Tiszavasvári Fehér-szik TT

23. Tiszadorogmai Göbe-erdı TT

24. Virágoskúti-halastórendszer

A felsorolásokból látható, hogy a nemzetközi jelentőségü vízi élőhelyek száma 17-ről 22-re, a hazai kiemelt jelentőségü vízi élőhelyek száma pedig 23-ról 24-re emelkedett.

Újabb elemként jelent meg az 56/2005 (VI.25.) FVM rendeletben - nemzetközi kötelezettséget átvezetve jelent meg a jogszabályban az ólomsörét használatának tiltása a kiemelt vizes élöhelyeken.

III. 


\section{AZ ÓLOMSÖRÉT HASZNÁLATA SZEMPONTJÁBÓL TILTOTT VÍZI ÉLŐHELYEK}

1. Sárvíz-völgye TK [26/1997. (VIII. 1.) KTM rendelet a Sárvíz-völgye Tájvédelmi Körzet létesítéséről];

2. Kiskunsági Nemzeti Park területéből a Tiszaalpári rét, a Miklapusztai területegység Bába-szék elnevezésü területe, valamint a Felsö-Kiskunsági szikes puszta területegységből a Dömsödi árapasztó, XXX-csatorna, Apaj Ürbő közti müút és a KNP határa által közbezárt területe [1800/1974. OTvH határozattal létesített Kiskunsági Nemzeti Park; 22/1996. (X. 9.) KTM rendelet a Kiskunsági Nemzeti Park bővítéséről];

3. Péteri-tavi Madárrezervátum TT és 100 méteres védőzónája (az OTvH elnökének 3/1976. határozatával létrehozott Péteri tavi Madárrezervátum Természetvédelmi Terület);

4. Baláta tó TT (a földművelésügyi miniszter 505510/41 számú határozata a Baláta tó védetté nyilvánításáról);

5. Borsodi-Mezőség TK területéből a Montaj-tó [9/1989. (VIII. 24.) KVM rendelet tájvédelmi körzetek létesítéséről];

6. Kecskeri puszta TT Dudás-fertő nevủ része [2/1990. (VI. 13.) KöM rendelet a Hajósi-kaszáló és löszpartok, valamint a Kecskeri-puszta természeti területek védetté nyilvánításáról, a Tiszatelek-tiszaberceli ártér Természetvédelmi Terület bővítéséről és természetvédelmi kezelők megnevezéséröl];

7. Körös-Maros Nemzeti Park területéből a szabadkígyósi puszták, a pitvarosi-puszták, a cserebökényi puszták; [3/1997. (I. 8.) KTM rendelet a Körös-Maros Nemzeti Park létesítéséröl - a tájvédelmi körzeteket védetté nyilvánító rendeletekben foglalt hrsz.-ok szerint -, Szabadkígyósi Tájvédelmi Körzet az Országos Természetvédelmi Hivatal elnökének 7/1977. OTvH határozata a Szabadkígyósi Tájvédelmi Körzet létesítéséről, Pitvarosi puszták Tájvédelmi Körzet a környezetvédelmi és vízgazdálkodási miniszter 3/1989. (II. 22.) KVM rendelete egyes természetvédelmi területek védetté nyilvánításáról és tájvédelmi körzetek létesítéséröl, Cserebökényi puszták Tájvédelmi Körzet a környezetvédelmi és területfejlesztési miniszter 18/1991. (XII. 24.) KTM rendelete a Cserebökényi puszták Tájvédelmi Körzet létesítéséről];

8. Nagybereki Fehér-víz TT (Országos Természetvédelmi Hivatal elnökének 12/1977. OKTvH számú határozata a Nagybereki Fehérvíz természetvédelmi területté való nyilvánításáról);

9. Sárréti TK [3/1986. (III. 9.) OKTH rendelkezés a Sárréti Tájvédelmi Körzet létesítéséröl];

10. Tiszavasvári Fehér-szik TT és 100 méteres védőzónája (az Országos Természetvédelmi Hivatal elnökének 4/1977. OKTvH számú határozata a Tiszavasvári „Fehérszik” természetvédelmi területté való nyilvánításáról);

11. Dabasi Turjános TT [6/1987. (VII. 10.) OKTH rendelkezés a Dabasi Turjános Természetvédelmi Terület fokozottan védetté nyilvánításáról és bővítéséről];

12. a Balaton-felvidéki Nemzeti Parkból a lesencei Nádas-mezö - a Balatonederics-Szigliget közút, Tapolca patak, Raposka-Balatonederics vasútvonal által határolt terület - [31/1997. (IX. 23.) KTM rendelet a Balatonfelvidéki Nemzeti Park létesítéséröl];

13. a Csaba-rét Soltszentimre 0224/1 hrsz. alatti ex lege védett területe és 100 méteres védőzónája;

14. Kiskunsági Nemzeti Park nemzetközi jelentőségő vadvízként (ramsari területként) közzétett Kiskunsági szikes tavak és Izsáki Kolon-tó területei;

15. Fertö-Hanság Nemzeti Park területéből a Fertő tó nemzetközi jelentőségủ vadvízként (ramsari területként) közzétett teljes hazai területe;

16. a nemzetközi jelentőségü vadvízként (ramsari területként) közzétett Tatai Öreg-tó TT;

17. a nemzetközi jelentőségủ vadvízként (ramsari területként) közzétett Velencei Madárrezervátum TT és a Dinnyési Fertő TT és 100 méteres védőzónájuk;

18. a nemzetközi jelentőségủ vadvízként (ramsari területként) közzétett Pacsmagi-tavak TT;

19. a Balaton-felvidéki Nemzeti Park nemzetközi jelentőségü vadvízként (ramsari területként) közzétett KisBalaton területe;

20. a nemzetközi jelentőségű vadvízként (ramsari területként) közzétett Balaton;

21. a Duna-Dráva Nemzeti Park területéből a nemzetközi jelentőségű vadvízként (ramsari területként) közzétett Gemenc, valamint a Béda-Karapancsa Duna-menti területei és holtágai;

22. Ócsai TK;

23. a Pusztaszeri TK-ból nemzetközi jelentőségü vadvízként (ramsari területként) közzétett szegedi Fehér-tó, a Tisza labodári és saséri területe, a Csaj-tó, a Baksi Nagylegelő és a pusztaszeri Büdösszék-tó fokozottan védett területe és 100 méteres védőzónájuk;

24. a Körös-Maros Nemzeti Park nemzetközi jelentőségủ vadvízként (ramsari területként) közzétett területei: a Kardoskúti Fehér-tó, a Biharugrai- és Begécsi-halastavak, az Ugrai-rét, a Csillaglaposai-legelő és a Sző-rét és 100 méteres védőzónájuk;

25. a nemzetközi jelentőségủ vadvízként (ramsari területként) közzétett Csongrádbokrosi Sós-tó;

26. a nemzetközi jelentőségű vadvízként (ramsari területként) közzétett Szaporcai Ó-Dráva-meder TT;

27. a nemzetközi jelentőségű vadvízként (ramsari területként) közzétett Mártélyi TK;

28. a nemzetközi jelentőségű vadvízként (ramsari területként) közzétett Rétszilasi-tavak TT és 100 méteres védőzónája; 
29. az Ipoly-völgy nemzetközi jelentőségủ vadvízként (ramsari területként) közzétett területe;

30. a Felsö-Tisza nemzetközi jelentőségű vadvízként (ramsari területként) közzétett területe;

31. a Hortobágyi Nemzeti Park nemzetközi jelentőségű vadvízként (ramsari területként) közzétett részei és azok 100 méteres védőzónája: Zám, Pentezug és Angyalháza puszták", a Hortobágyi-halastó, a Kiskörei-víztározó északi része (Tiszafüredi Madárrezervátum), a Kiskörei-víztározó középső része (Poroszlói-medence) és az Egyek-pusztakócsi mocsarak területéből a Hagymáslapos, a Jusztus-mocsár és a Fekete-rét;

32. a Tokaj-Bodrogzugi TK-ból a nemzetközi jelentőségủ vadvízként (ramsari területként) közzétett Bodrogzug terület;

33. a nemzetközi jelentőségủ vadvízként (ramsari területként) közzétett Böddi-szék és Sóséri-puszta és 100 méteres védőzónája."

A 72/2012 (VII.24.) VM rendelet pontosító 27/A § szerint (1) Az 5. számú melléklet II. részében felsorolt vízivad fészkelése és vonulása szempontjából nemzetközi jelentőségü és hazai kiemelt jelentőségü vízi élőhelyeken a vadászati hatóság szabályozza a vízivad vadászat rendjét. Ebben szabályozza a vízivad vadászatának helyét, módját, idejét, gyakoriságát.

A jogszabály sem a vízivad fészkelési és vonulási szempontból nemzetközi jelentőségű vízi élőhelyek, sem a hazai kiemelt jelentőségü vízi élőhelyek, sem az ólomsörét használata szempontjából tiltott vízi élőhelyek listáján nem változtatott a 7/2010 (II.2.) FVM rendelet 3. mellékletében közöltekhez képest.

A 24/2017. (V. 17.) FM rendelet a vad védelméről, a vadgazdálkodásról, valamint a vadászatról szóló 1996. évi LV. törvény végrehajtásának szabályairól szóló 79/2004. (V. 4.) FVM rendelet módosításáról a kíméleti területek vonatkozásában változást nem hozott a korábbi szabályozásokhoz képest.

\subsection{A VADÁSZATI SZABÁLYOZÁS NEMZETKÖZI ÉS HAZAI JOGI KÖRNYEZETE}

Ma már a vízivad védelmét - és vadászatát - nemzetközi egyezményekben vállalt, $\mathrm{s}$ a nemzeti jogalkotásban érvényesített biztosítékok, védelmi intézkedések szavatolják. Az alábbiakban vázlatosan közöljük, hogy mit takarnak az egyes egyezmények függelékeiben rögzített kritériumok és azt is, hogy a vadászható fajok közül melyeket sorolják fel az egyes listákon.

\section{BONNI EGYEZMÉNY}

Az Egyezmény célja a vándorló fajok és élőhelyeik megörzése az egész Földkerekségen. Magyarország 1983. november 1. napjától tagja az 1979-ben életre hívott Egyezménynek (Kihirdetve: 1986. évi 6. Tvr.). Az Egyezmény 3 fö témára összpontosít, ebből

- Az I. függelékben felsorolt veszélyeztetett fajok védelme érdekében szigorú intézkedéseket kell hozni

- A II. függelékben felsorolt fajok populációinak megőrzésére többoldalú megoldásokat kell kötni.

Magyarország az Egyezményben vállalt kötelezettségeit mind teljesítette (FÜLEKY, 2000).

\section{Függelék}

Az I. függelék 76 fajt tartalmaz, ezek azok, amelyek megbízható adatok alapján veszélyeztetettek. Ebbe a kategóriába sorolt fajok egyedeinek zsákmányolását az érintett tagállamoknak meg kell tiltaniuk. Vadászható vízivad faj nincs ebben a kategóriában!

\section{Függelék}

A II. függelék 55 fajt tartalmaz, mindazokat a fajokat, amelyeknek kedvezőtlen védelmi helyzete és megóvása, gondozása nemzetközi megállapodást igényel, továbbá amelyek védelmi helyzetére kedvezően hatna a nemzetközi együttmüködés. A II. függelékbe sorol fajok esetében, tehát nem kell feltétlenül megtiltani a 
vadászatot. Ha indokolt, ugyanaz a vándorló faj felvehető az I. és II. függelékbe is. Vadászható vízivad fajok közül ide tartozik a nagy lilik (Anser albifrons), a vetési lúd (Anser fabalis), a nyári lúd (Anser anser), a tőkés réce (Anas platyrhynchos), a böjti réce (Anas querquedula), a csörgő réce (Anas crecca), a barátréce (Aythya ferina), a kerceréce (Bucephala clangula) és a szárcsa (Fulica atra).

A tagországok 7 többoldalú megállapodást kötöttek már, közülük számunkra legfontosabb az AFRIKAI ÉS EURÁZSIAI VÁNDORLÓ VÍZIMADARAK VÉDELMÉRE VONATKOZÓ EGYEZMÉNY (Agreement on the Conservation of African-Eurasian Migratory Waterbirds). Kihirdetve a 2003. évi XXXIII. Törvényben.

\section{WASHingtoni EgYeZMÉNY - CITES}

A CITES a kereskedelem által veszélyeztetett fajok védelmével foglalkozik. Az Egyezményt 21 ország alapította 1973-ban, ma 146 tagországa van. Létrehozásában döntő szerepet játszott az a felismerés, hogy bizonyos állat- és növényfajokat a kipusztulás szélére sodort az egyre nagyobb méreteket öltő nemzetközi kereskedelem. Magyarország 1985-ben csatlakozott az Egyezményhez (RoDICS, 2000) [Kihirdetve: 1986. évi 15. Tvr. és végrehajtására a 4/1990 (XII.7) KTM rendelet]. [Újra kihirdetve: a 2003. évi XXXII. Törvényben, az új Vhr: 271/2002. (XII. 20.) Korm. sz. rendelet].

\section{Függelék}

Az I. függelékbe sorolandók azok a fajok, amelyekre teljes kereskedelmi tilalmat kell elrendelni. Hazai vadászható vízivad (általában madár) fajok közül ebbe a függelékbe nem került egy faj sem.

\section{Függelék}

A II. függelékbe azok az állat- és növényfajok tartoznak, amelyek ma még nem állnak a kipusztulás szélén, de ahhoz, hogy ezt a sorsot elkerüljék, kereskedelmüket szabályozni kell. Hazai vadászható vízivad (általában madár) fajok közül ebbe a függelékbe nem került egy faj sem.

\section{Függelék}

A III. függelékbe azon fajok tartoznak, amelyek esetében a nemzetközi kereskedelem ellenőrzéséhez valamely tagállam nemzetközi segítséget kér. A hazai, korábban vadászható vízivad (általában madár) fajok közül a csörgö réce (Anas crecca) és a böjti réce (Anas querquedula) tartozik ebbe a függelékbe, mindkét fajt Ghána vette fel a jegyzékbe.

\section{EC 338/97 RENDELET. A VADON ÉLŐ Állat- ÉS NÖVÉNYFAJOK VÉDELME AZOK SZABÁLYOZOTT KERESKEDELME RÉVÉN}

A Rendelet tulajdonképpen a CITES végrehajtását szabályozza az Európai Unióban. Az EU a CITES Függelékeinél szigorúbb fajlistákat használ, az I. Függelék helyett van az „A” Melléklet, a II. Függelék helyett a „B” Melléklet és a III: Függelék helyett a „C” Melléklet. Van egy - a CITES-ben nem szereplö - „D” Melléklet is, amely monitorozó feladatokat ró a tagállamokra. Az eredeti CITES szabályozásnak megfelelően az

„A” Mellékletben szereplő fajok esetében teljes a kereskedelmi tilalom a vadon élő példányokra. Tenyésztés esetén is csak akkor van lehetőség a kereskedelemre, ha az egyed, vagy származéka mikrochippel jelölt. Egy ilyen korábban vadászható vízivad (általában madár) fajunk van, a böjti réce (Anas querquedula).

„B” Mellékletben szereplő fajok esetében korlátozott kereskedelemre mód van, megfelelő export, illetve import engedélyek birtokában. E mellékleten nem szerepel hazai vadászható vízivad (általában madár) faj.

„C" Mellékletben szereplő fajok behozatala esetében akkor kell az exportengedély, ha a példány olyan országból jött, amelyik felvetette a fajt a CITES III. Függelékébe. Egyéb esetekben a származást kell tudni igazolni. Kivitelkor azonban mindenesetben CITES exportengedély szükséges. Ilyen faj a csörgő réce (Anas crecca.

Ezen előírások átvétele a hazai jogrendbe a 271/2002. (XII: 20.) Korm. rendelettel megtörtént. 


\section{BERNI EGYEZMÉNY}

Az Európa Tanács keretében 1979-ben kidolgozott Egyezmény az európai vadon élő növények, állatok és természetes élőhelyeik védelmére az első teljes körü természetvédelmi egyezménynek tekinthető, ami megnyilvánul abban, hogy védelemnek tekinti a szabályozott meghatározott időszakokban, korlátozottan stb., azaz ellenőrzötten történő - hasznosítást. A mellékleteiben eszerint sorolja a védett fajokat (NECHAY, 2000).

\section{Melléklet}

Az I. melléklet tartalmazza a fokozottan védett növényfajokat.

\section{Melléklet}

A II. melléklet tartalmazza a fokozottan védett állatfajokat. Vadászható vízivad (általában madár) fajok értelemszerüen nincsenek a felsorolásban.

\section{Melléklet}

A III. Mellékletben szereplő fajok védettek, de számukra a védelmet a teljes tilalom helyett a hasznosítás szabályozott, fenntartható formája jelenti. A jelenleg, vagy a közelmúltban vadászható vízivad fajok közül e kategóriába sorolhatók az alábbiak: nagy lilik (Anser albifrons), vetési lúd (Anser fabalis), nyári lúd (Anser anser) tőkés réce (Anas platyrhynchos), böjti réce (Anas querquedula), csörgőréce (Anas crecca), barátréce (Aythya ferina), kerceréce (Bucephala clangula) és a száresa (Fulica atra).

\section{Melléklet}

A IV. mellékletben sorolják fel azokat a módszereket, illetve eszközöket, amelyek nem alkalmazhatók a III. Mellékletben, vagy engedélyezett esetekben a II. Mellékletben felsorolt állatfajok befogása vagy elejtése során.

\section{EU MADÁRVÉdELMI IRÁNYELVEK - 79/409/EGK.}

Az EU Közösségek Tanácsa 1973. november 22-i Irányelvei a tagállamok területén előforduló valamennyi őshonos, vadonélő madárfajra - kifejlett példányaira, tojásaikra, fészkeikre, fiókáikra és élőhelyeikre - vonatkoznak. Megtiltja - a vadászható fajok kivételével - a madarak bármely korú és ivarú egyedének bármilyen módszerrel történő szándékos pusztítását, vagy befogását, szándékos háborgatását, egyedeinek fogva tartását. Különös figyelmet fordítanak valamennyi madárfaj élőhelyeinek megőrzésére, illetve azok visszaállítására. Néhány faj kivételével teljes tilalmat rendel el a kereskedelemre. Állományhasznosítást csak azon fajok esetében engedélyez, ahol azt biológiai státusuk lehetővé teszi. Megállapítja, hogy bizonyos fajok állapota lehetövé teszi azok elfogadható mértékü vadászati hasznosítását, ami fenntartható módon kell, hogy történjen (wise use). Tilalom alá helyezi a befogás, vadászat és pusztítás bizonyos eszközeit, módszereit és bizonyos közlekedési eszközök használatát vadászati célra, valamint tiltja a vadászatot a költőterületekre tartó vonulás, továbbá a költés, illetve a fiókanevelés ideje alatt, még a kárt okozó fajok esetében is.

\section{Melléklet}

$\mathrm{Az}$ I. Mellékletben felsorolt fajok különös intézkedést igényelnek. Gondoskodni kell az itt felsorolt fajok, valamint az ebben a mellékletben nem szereplő, de vonuló fajok védelméről, különös tekintettel a szaporodási, vedlési, telelési területekre, a vándorlási útvonal pihenőhelyeire, a nemzetközi jelentőségű vizes élőhelyek védelmére (KÜLÖNLEGES MADÁRVÉDELMI TERÜLETEK). Mint vonuló madárfajok, a vadászható vízivad fajok közül az alábbiak esetében szükséges KÜLÖNLEGES MADÁRVÉDELMI TERÜLETEKet kijelölni: nagy lilik (Anser albifrons), vetési lúd (Anser fabalis), tőkés réce (Anas platyrhynchos), csörgő réce (Anas crecca), barátréce (Aythya ferina), kerceréce (Bucephala clangula).

\section{Melléklet}

A II. Mellékletben felsorolt fajok vadászhatók a nemzeti törvények szerint. A tagállamok gondoskodnak arról, hogy a felsorolt fajokra sem az utódnevelés időszakában, sem a reprodukciós folyamat különböző fázisaiban, költöző fajok esetében pedig a költőterületekre való visszatérés közben ne vadásszanak. 


\section{II/1. Melléklet}

A II/1. Mellékletben felsorolt fajok vadászhatók az Irányelvek által érintett egész területen. Vadászható vízivad fajok közül e kategóriába sorolhatók voltak: vetési lúd (Anser fabalis), csörgő réce (Anas crecca), tőkés réce (Anas platyrhynchos), böjti réce (Anas querquedula), barátréce (Aythya ferina) és a szárcsa (Fulica atra). Ebbe a kategóriába sorolták egyébként a másutt már korábban, nálunk csak 2012 óta vadászható nyári ludat (Anser anser) is.

\section{II/2. Melléklet}

A II/2. Mellékletben felsorolt fajok csak a feltüntetett tagállamok területén vadászhatók. A vadászható vízivad fajok közül e kategóriába sorolhatók: a nagy lilik (Anser albifrons) és a kerceréce (Bucephala clangula).

\section{Melléklet}

A Tagállamok a III. Melléklet fajait kivéve betiltják az összes madárfaj élö és elpusztult egyedeinek, könnyen felismerhető testrészeinek, származékainak adásvételét, avagy ilyen célból való fogva tartásukat és felkínálásukat.

\section{III/1. Melléklet}

A tilalom nem vonatkozik a III/1. Mellékletben felsorolt fajokra, ha megszerzésük legálisan történt. A vadászható vízivad fajok közül e kategóriába sorolható a tőkés réce (Anas platyrhynchos).

\section{III/2. Melléklet}

A III/2. Mellékletben felsorolt fajokra vonatkozó kereskedelem engedélyezhetö, ha megszerzésük legálisan történt, és a tagállam előzetesen egyeztetett az EU Bizottsággal. A vadászható vízivad fajok közül e kategóriába sorolhatók: nagy lilik (Anser albifrons), csörgő réce (Anas crecca), barátréce (Aythya ferina), szárcsa (Fulica atra).

1. táblázat: A Magyarországon vadászható (vagy korábban vadászható) vízivad fajok védelmi helyzete a nemzetközi egyezmények tükrében

Table 1: Conservation positions of huntable (or former huntable) waterfowl species in Hungary in the light of international agreements

\begin{tabular}{|c|c|c|c|c|c|}
\hline Faj & CITES & EC 338/97 & Bern & Bonn & 79/409/EGK \\
\hline $\begin{array}{l}\text { Nagy lilik } \\
\text { Greater White-fronted Goose }\end{array}$ & - & - & III & II & $\mathrm{II} / 2 \quad \mathrm{III} / 2$ \\
\hline $\begin{array}{l}\text { Vetési lúd } \\
\text { Bean Goose }\end{array}$ & - & - & III & II & II/1 \\
\hline $\begin{array}{l}\text { Nyári lúd } \\
\text { Greylag Goose }\end{array}$ & - & - & III & II & $\mathrm{II} / 1$ \\
\hline $\begin{array}{l}\text { Tőkés réce } \\
\text { Mallard }\end{array}$ & - & - & III & II & II $/ 1 \quad$ III $/ 1$ \\
\hline $\begin{array}{l}\text { Böjti réce } \\
\text { Garganey }\end{array}$ & III (Gh*) & A & III & II & $\mathrm{II} / 1$ \\
\hline $\begin{array}{l}\text { Csörgö réce } \\
\text { Eurasian Teal }\end{array}$ & III. (Gh*) & $\mathrm{C}$ & III & II & $\mathrm{II} / 1 \quad \mathrm{III} / 2$ \\
\hline $\begin{array}{l}\text { Barátréce } \\
\text { Common Pochard }\end{array}$ & - & - & III & II & $\mathrm{II} / 1 \quad \mathrm{III} / 2$ \\
\hline $\begin{array}{l}\text { Kerceréce } \\
\text { Common Goldeneye }\end{array}$ & - & - & III & II & $\mathrm{II} / 2$ \\
\hline $\begin{array}{l}\text { Szárcsa } \\
\text { Eurasian Coot }\end{array}$ & - & - & III & II & $\mathrm{II} / 1 \quad \mathrm{III} / 2$ \\
\hline
\end{tabular}

* Gh: Ghana

1996. ÉVI LV. TöRVÉNY A VAD VÉDELMÉRŐL, A VADGAZDÁLKODÁSRÓL, VALAMINT A VADÁSZATRÓL

A VADÁSZATI TÖRVÉNY a vadat úgy kezeli, mint a Föld megújuló természeti erőforrásainak, valamint a biológiai életközösségnek pótolhatatlan részét, az egész emberiség 
és nemzetünk kincsét, amelyet természetes állapotban meg kell őrizni a jövő nemzedékek számára. A Törvény tehát a természet védelme és a vadállomány ésszerü hasznosítása érdekében született, s csak azon fajokra terjed ki, amelyek nem védettek, s amelyeket a vadászati jog hasznosítása érdekében tartanak bekerített helyen. A Törvény és végrehajtási rendeletei (Vhr.) meghatározza a mindenkori vadászható állatfajokat, tehet, amelyeket vadászati-vadgazdálkodási szempontból vadnak lehet és kell tekinteni. Az LV. Törvény címében is rögzített sorrend alapján - legfontosabb feladata a vad és élöhelyének védelme. Az erre vonatkozó rendelkezéseket a II. Fejezet tartalmazza. Rendelkezik a vad nyugalmának megóvásáról, tiltja a vad búvó-, lakó-, és táplálkozási, valamint szaporodási vagy költési helyének zavarását. Tilos a madarak fészkének és fészkelésének vadászati célra engedélyezett vagy bármely más eszközzel való zavarása, megrongálása, vagy elpusztítása. Tilos a vad kínzása. A vadat elejteni, elfogni - a Berni Egyezménnyel összhangban - nem élvefogó csapdázási módszerrel - különösen csapóvas, hurok, horog alkalmazásával - valamint veremmel, méreggel elfogni, elpusztítani. Tiltott csapdázási módszer a lábfogó csapóvas alkalmazása is. (Humán- vagy állategészségügyi indokok alapján a vadászati hatóság - a természetvédelmi hatóság előzetes szakhatósági hozzájárulásával - engedélyezheti nem élvefogó csapda, illetve - a mérgező hatású anyagok használatára vonatkozó szabályok figyelembevételével - szelektív méreg alkalmazását.) Élő vad befogás esetén a befogót legalább 12 óránként, éjszakai fogás esetén napkeltekor ellenőrizni kell, s a lehető leggyorsabban, de legkésőbb 2 órán belül el kell távolítani a vadat a befogóból.

Mesterséges tenyésztés folytatásához, a vad zárttéri tartásához, a vad vadászterületre történő kiengedéséhez a vadászati hatóság engedélye szükséges, amihez szükséges a területileg illetékes társ szakhatóságok (természetvédelmi - védett területen, erdészeti erdőterületen, állategészségügyi - mindenütt) hozzájárulása is. Mindezek elmulasztása esetén vadgazdálkodási szabálysértés történik. A kitelepített vadnak érvényes állategészségügyi igazolással kell rendelkezni, aminek alapján a természeti környezetben élő állatfajoknak a telepített vad által állatbetegségekkel történő fertőzése kizárható.

Magyarország állatföldrajzi környezetében nem honos állatfaj vadászati célú telepítését korábban a FÖLDMÜVELÉSÜGYI ÉS VIDÉKFEJLESZTÉSI MINISZTÉRIUM - a KÖRNYEZETVÉDELMI MINISZTÉRIUMmal egyetértésben -, jelenleg a FÖLDMÜVELÉSÜGYI MINISZTÉRIUM engedélyezheti. Napjainkban - az európai trendeknek és szemléletváltáshoz is igazodva - nem történtek ilyen kezdeményezések.

A vadászatra jogosult köteles a vadászterületén élő vadállományt, annak biológiai sokféleségét fenntartani, valamint a vad és élőhelye örzéséröl gondoskodni. A föld tulajdonosának, használójának egyetértésével a vad és élőhelye védelmét szolgáló létesítmények, berendezések állíthatók fel. A vadgazda köteles megóvni a vadállomány egészségét, megelőzni, megszüntetni, terjedését megakadályozni a fertőző betegségeknek. Köteles tájékoztatni minderről az állategészségügyi hatóságot, növényvédőszer okozta károsodás - vagy annak gyanúja - esetén a növényvédelmi, valamint a népegészségügyi hatóságokat. Amennyiben a vadászatra jogosult a vad és élőhelyének védelmére elöírt kötelezettségének nem, vagy nem megfelelő módon tesz eleget, akkor a vadászati hatóság határozatban - megfelelő határidő megjelölésével - felhívja e kötelezettség teljesítésére, amelynek elmulasztása esetén a szükséges munkálatokat a vadászatra jogosult költségére és felelősségére elvégeztetheti.

A vad és élőhelyének védelme érdekében tilos vadászni (a) tiltott vadászati eszközökkel, (b) tiltott vadászati módon, (c) vadászati tilalmi időben, (d) vadászati kíméleti területen, (e) vadászati tilalom hatósági elrendelése esetén.

A vadászati év Magyarországon az év március 1.-én kezdődik és a következő év februárjának utolsó napján (28 vagy 29) ér véget. A vadászati idény a vadfajok vadászatának ezen perióduson belül kijelölt naptári időszaka, amelyet az FVM miniszter a 
természetvédelemért felelős miniszterrel egyetértésben, rendeletben állapít meg. A vadászati év vadászati idényen kívüli időszakát kíméleti időnek nevezzük. Azt a vadfajt, amelyre a Miniszter vadászati idényt nem állapít meg, az egész vadászati év során kímélni kell. Ettől a vadászati hatóság hivatalból, vagy kérelemre indított eljárás során - a társ szakhatóságok hozzájárulásával - a vad védelme, az erdészeti és növényi kultúrák, a mesterséges vizek halállományának védelme, járványveszély, vagy a vad által okozott folyamatos károkozás megelözése érdekében (valamint tudományos, oktatási és kutatási célból) eltérhet. Ennek során (a) a vadászidényt meghatározott vadászterület(ek)re meghosszabbíthatja, (b) lerövidítheti, (c) korlátozhatja vagy megtilthatja egy vagy több vadfaj vadászatát, (d) túlszaporodás esetén vadászati tilalmi időben vadászatot engedélyezhet, vagy rendelhet el.

Természetvédelemi oltalom alatt álló állatfaj eseti vadászatát - az oltalom feloldása után, a vadászati hatóság elözetes szakhatósági hozzájárulásával - a természetvédelmi hatóság engedélyezi.

A vadászati idényeket, valamint a vízivad fészkelési és vonulási szempontból nemzetközileg is kiemelt jelentőségü vízi élőhelyeket az FVM Miniszter rendeletben szabályozza, utóbbi esetben a vadászat rendjét is szabályozzák a vadászati és természetvédelmi hatóságok. A vadászati hatóság a vadászterületet, vagy annak egy részét vadászati kíméleti területnek minősítheti, ha (a) a vad- és élőhelyvédelem másként nem biztosítható, (b) vízivad fészkelése és vonulása idejére, (c) halastó vagy természetes víz lehalászása idejére, (d) a települések környezetének meghatározott részét a nyugalom és a közbiztonság érdekében.

\section{A VÍZIVADFAJOK TERÍTÉKDINAMIKÁJA 1884-2015}

A vízivad teríték alakulását elemezve nehéz helyzetben vagyunk, mert a statisztikákban mindenkor külön-külön összevonva szerepeltek a libák és a kacsák, megint csak külön a szárcsa. Tovább nehezíti az értékelést, hogy egyrészt a mintegy 130 évre igen hiányosan állnak rendelkezésre az adatok, másrészt mindenkor a hatályos törvényeknek megfelelö, értelemszerüen változó fajszámra és idényhosszra alapulnak. Csak az utóbbi mintegy 20 év statisztikái (CSÁNYI 1996; 1998; 1999; 2000; 2001; 2002; 2003; 2004; 2005; CSÁNYI et al., 2006; 2007; 2008; 2009; 2010; 2012a; 2012b; 2013; 2014; 2015; 2016) adnak meg faji szintü terítékeket, amelyek a korábban kidolgozott MAGYAR VÍzIVAD GAZDÁLKODÁSI TERV ajánlásai alapján (FARAGÓ, 1997b) került bevezetésre. A fenti bizonytalansági tényezők ellenére mégis úgy gondoljuk, hogy nem érdektelen a tartamos statisztikai adatsorok nyomon kísérése, amely a fajcsoportok állományváltozását is tükrözi.

\subsection{A VADLUDAK VADÁSZATA}

A Pannon régió a három vadászható vadlúdfaj a vetési lúd, a nagy lilik és a nyári lúd szempontjából kiemelkedően fontos telelőterületnek számít Európában. Nem kétséges tehát, hogy nevezett fajok populációinak fenntartható, bölcs hasznosítása azok védelme szempontjából meghatározó jelentőségü. Tudott, hogy a vadludak igen érzékenyek a környezet állapotváltozásaira, mindenekelőtt a klimatikus és hidrológiai viszonyokra, valamint a táplálékkínálatra. Mindezek mellett a nyugalom biztosítása a meghatározó. 


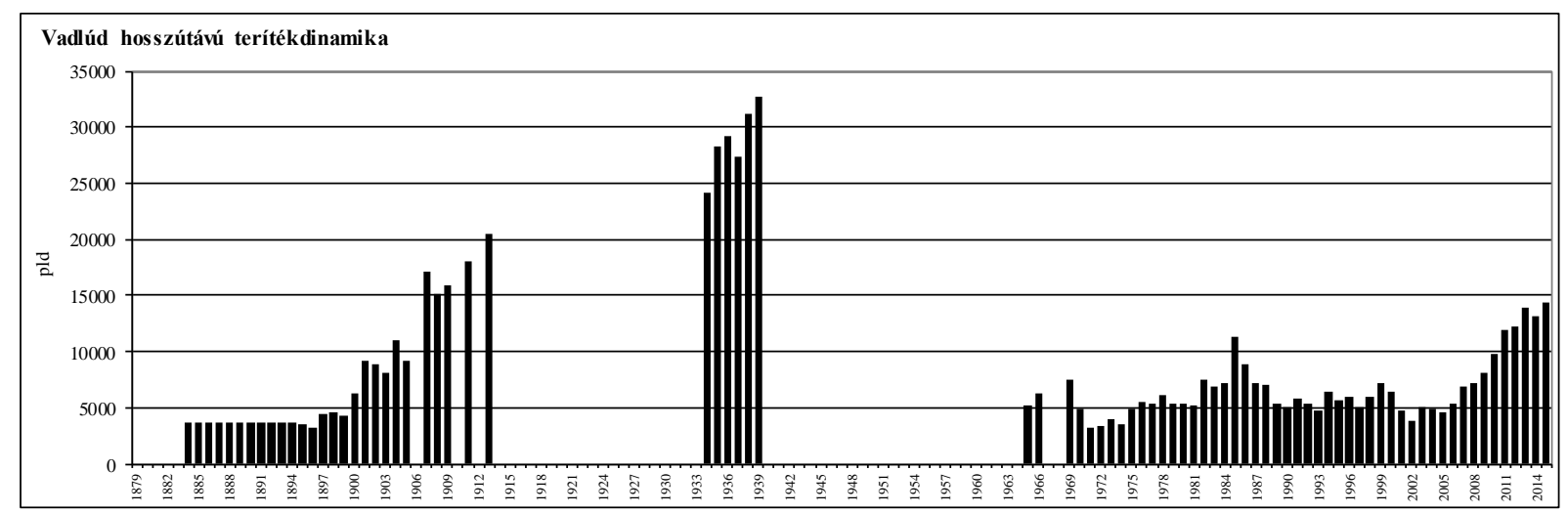

2. ábra: A vadlúd teríték alakulása Magyarországon az 1884-2015 közötti 131 évben Figure 2: Dynamics of goose bag in Hungary over 131 years between 1884 and 2015

A vadászati hasznosításnak a populációdinamikára nemcsak közvetlen, de közvetett hatása is van, ezért mindenképpen szükséges mértékének, szabályozási módjainak és mindezek eredményességének elemzése, értékelése.

A vadliba teríték a 19-20. század fordulójának történelmi Magyarországán 4000-6000 pd körül változott, azután azonban erőteljes volt a növekedés. 1905-ben már több mint 9000 pd-t, 1909-ben 15800 pd-t, 1913-ban 19600 pld-t lőttek (FARAGÓ, 2009). Ekkor kezdett kialakulni a magyar libavadászat nemzetközi nimbusza. Az 1930-as években a teríték meghaladta a 25000 pd-t, a maximumot - 32700 pd-t - az 1939/1940-es szezonban érték el. A II. világháborút követően a terítékeket csak az 1960-as évek közepétől tudjuk nyomon kísérni, amikor 5000-7000 pd-t ejtettek el. Az 1970-es évek elején a teríték 3000-4000 pd között változott, majd ezt követően folyamatos volt a terítéknövekedés. A két kiugró évben, 1985-ben és 1986-ban 11400 és 8900 pd-t ejtettek el, azt követően jelentős visszaesést tapasztalhattunk. Az 1990-es években újfent csak 5000-6000 pd között stabilizálódott a teríték (FARAGÓ, 1982a; CSÁNYI, 1996). 2005 után ismételten terítéknövekedésnek vagyunk tanúi annak ellenére, hogy a vetési lúd állománya jelentősen csökkent, viszont a nagy lilik állománya, s így terítéke növekedett, s 2012 óta vadászható a nyári lúd is (2. ábra).

Az 1970-2015 közötti 45 évben elejtett libák terítékdinamikáját elemezve (3. ábra) négy jól elkülöníthető periódus mutatható ki.

(1) 1970-1985 között a teríték háromszorosára nőtt, 1985-ben meghaladta a 10000 példányt. A két vadászható faj (vetési lúd és a nagy lilik) területileg jól differenciálódott az ország K-i és Ny-i fele között. A Dunántúlon lött vetési ludak a vadlúdteríték 50\%-át, az Alföldön lött nagy lilikek annak ugyancsak 50\%-át tették ki. Ez az arány 1983-ig nem változott, tartósan magas volt a nagy lilik hasznosítása az Alföldön - föként a külföldi vadászvendégek által. A vadászati módokat és a teríték napi nagyságát még nem szabályozta hatékonyan a törvény. A magas teríték mellett az éjszakázó-helyek állandó zavarása a nagy lilik telelő állományának csökkenését vonta maga után. Ekkor nőtt meg ugrásszerüen a Pontuszi-régióban telelő nagy lilikek mennyisége. 1984-1985-ben a nagy lilikek aránya az összes teríték növekedése mellett 20\%-ra csökkent. 


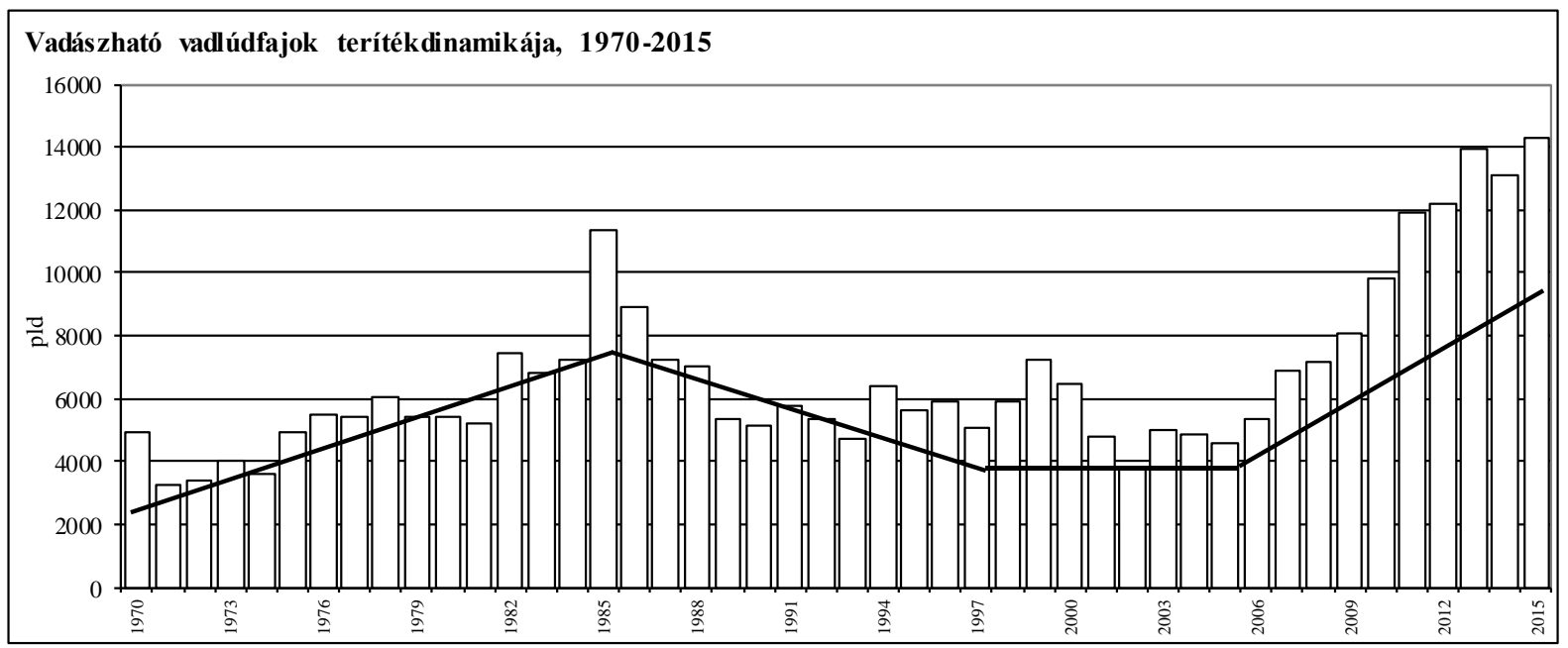

3. ábra: A vadlúd teríték alakulása Magyarországon az 1970-2015 közötti 35 évben Figure 3: Dynamics and trends of goose bag in Hungary over 35 years between 1970 and 2015

(2) 1986-1993 között a teríték jelentősen, mintegy felére, 4700 példányra esett vissza, úgy hogy a periódus végére mindössze 200 nagy liliket lőttek egész Magyarországon. Ekkor tett javaslatot MAGYAR VÍZIVAD KUTATÓ CSOPORTUNK a nagy lilik vadászatának engedélyhez kötésére. 1992-től egyébként ugyancsak javaslatunkra a libafajok vadászati terítékstatisztikáját faji bontásban rögzítik.

(3) 1994-2005 között a teríték a vetési lúd és az összes liba vonatkozásában enyhe csökkenést, a nagy lilik esetében emelkedést mutatott. Mint említettük, erre az időszakra vonatkozóan már rendelkezünk a két faj tényleges terítéknagyságaival. A teríték zömét kezdetben - a nagy lilik erősen korlátozott hasznosítása miatt - a vetési lúd tette ki. 1998-tól kezdődően - összhangban az emelkedő egyedszámmal és a károkozással - megnőtt a kiadott vadászati engedélyek száma. Érdemes tudni ennek megítéléséhez, hogy Magyarországon 1995 után kezdődött a mezőgazdasági területek kárpótlása és privatizációja, ami által emelkedett a területek kárérzékenysége. (A kisbirtokot érintő eseti libakárosítás gazdasági következményei erőteljesebbek voltak, mint azt a nagybirtokok esetében tapasztaltuk.). A periódus utolsó két évében a vetési lúd teríték a felére esett vissza, ami visszatükrözi a vetési lúd telelő populációjának csökkenését (FARAGÓ, 2005c).

(4) 2006-2015 között a teríték a vetési lúd esetében további csökkenést, a nagy lilik esetében pedig háromszoros növekedésdinamikát mutatott. Elöbbi faj terítéke 2015-ben 1152 pd, utóbbié 10485 pd volt. Tovább nőtt a terítékre hozott vadludak összes száma - 2015-re elérte a 14314 példányt - amiatt, hogy 2012-vel vadászható lett a nyári lúd (Anser anser), s terítéke évi 1513 és 2677 pd között változott a feldolgozott 4 idény során.

Az 1994-től számított időszak fajonkénti statisztikai adatszolgáltatása (CSÁNYI, CSÁNYI 1996; 1998; 1999; 2000; 2001; 2002; 2003; 2004; 2005; CsÁNYI et al., 2006; 2007; 2008; 2009; 2010; 2012a; 2012b; 2013; 2014; 2015; 2016) lehetővé teszi a teríték országos és regionális szintü megoszlás- és trend-elemzését.

A VETÉSI LÚD terítéke az elmúlt időszakban a korábbinak mintegy felére esett vissza (1994: $6071 \mathrm{pd} \rightarrow$ 2004: 2756 pd $\rightarrow$ 2015: 1152 pd)(4. ábra; 1. melléklet), összhangban annak állományalakulásával. 

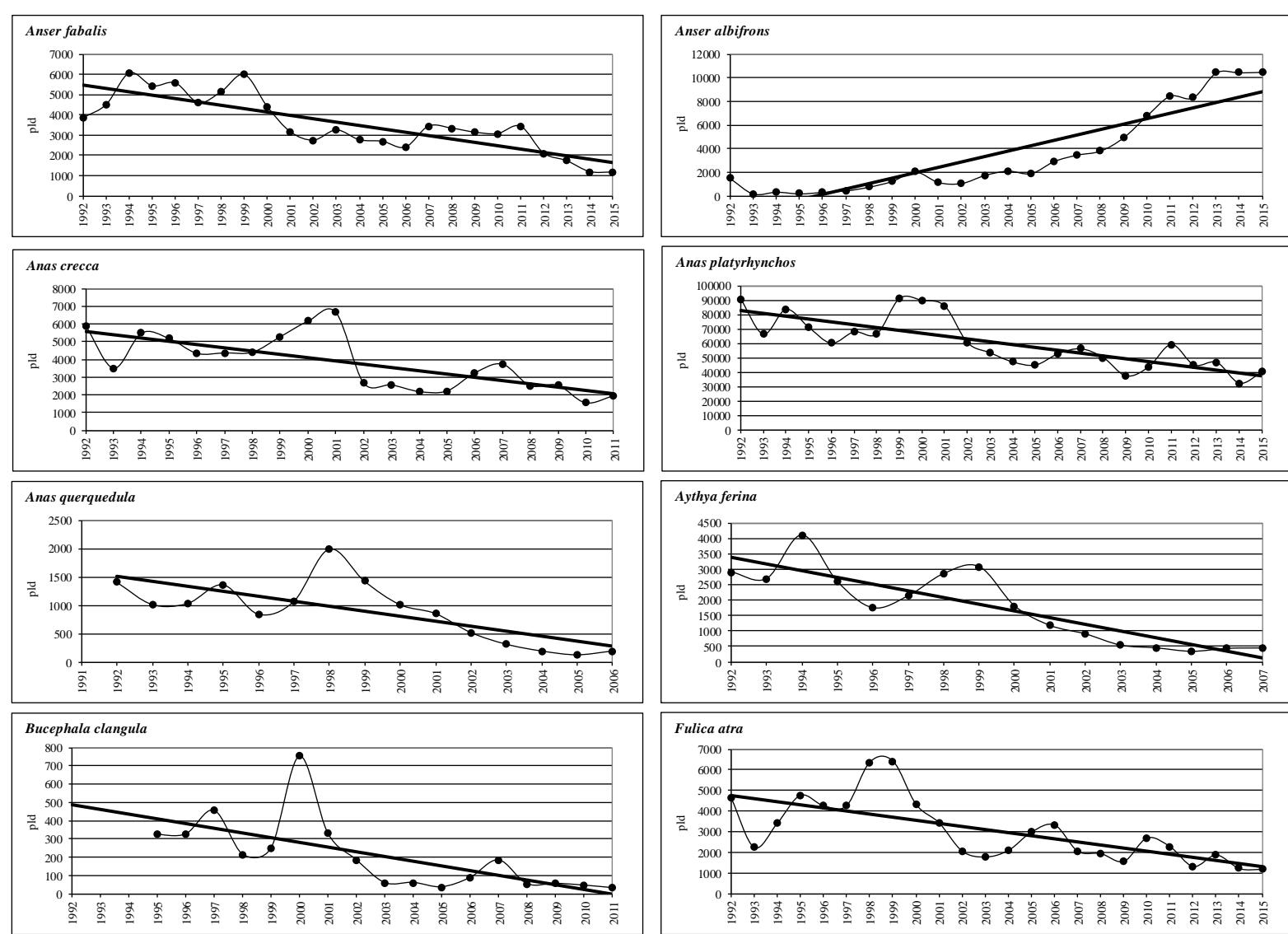

4. ábra: A vízivad teríték alakulása Magyarországon 1992- óta

Figure 4: Dynamics of hunting bag of huntable waterfowl species since 1992-in Hungary

\section{Regionális trend}

Észak-Dunántúl: az országos trendet is meghatározó, azzal egyező lefutású erőteljesen csökkenö

Dél-Dunántúl: határozottan csökkenő

Duna-Tisza köze: határozottan csökkenő

Tiszántúl: határozottan csökkenő

Észak-Magyarország: határozottan csökkenő (5. ábra).

Hasznosítása - ahogy előfordulása is - a Dunántúlra koncentrálódik, amit jól mutat, hogy az Észak-Dunántúl (53\%) és a Dél Dunántúl (19\%) együttesen a teríték több mint 2/3-át (72\%) adja. Jelentősebb még a Duna-Tisza köze vetési lúd terítéke (15\%), míg a Tiszántúlon átlagosan csak az éves mennyiség 10\%-a, Észak-Magyarországon pedig 2\%-a esik. Az elmúlt évtizedekben jelentősen csökkent a Dunántúlon elejtett vetési ludak részesedése a terítékböl, közülük föként az Észak-Dunántúlon ejtettek el arányaiban egyre többet $(38 \% \rightarrow 59 \%)$. A DélDunántúlon szolidabb, a Duna-Tisza közén eröteljesebb teríték és teríték részarány csökkenésnek vagyunk tanúi. Észak Magyarország szerepe elhanyagolható, hiszen részesedése 1-4\% közötti értékek hullámzását mutatja. Külön kell foglalkoznunk a Tiszántúl vetési lúd terítékének kérdésével, mert a statisztikák szerint a annak részesedése az országos mennyiségből 8\%-ról 19\%-ra emelkedett. Történt ez akkor, amikor gyakorlatilag az utolsó évtizedben már nem figyeltünk meg vetési ludat a MAGYAR VízIVAD MONITORING tiszántúli megfigyelési területein. Ennek a jelenségnek egyedüli oka és magyarázata, hogy a nagy lilik terítékkorlátozás miatti elejtett többlet darabszám egy részét a gazdálkodók vetési lúdként jelentik le, meghamísítva ezáltal a statisztikát (6. ábra). 
A NAGY LILIK terítéke az elmúlt három évtizedben a korábbinak mintegy négyszeresére nött (1996: 188 pld $\rightarrow$ 2004: 2117 pld $\rightarrow$ 2015: 10485 pd)(4. ábra; 2. melléklet), összhangban annak állomány-alakulásával, illetőleg a vadászati korlátozás fokozatos feloldásával (FARAGÓ, 2004a).

\section{Regionális trend}

Észak-Dunántúl: határozottan növekvő

Dél-Dunántúl: enyhén növekvő

Duna-Tisza köze: enyhén növekvő

Tiszántúl: az országos trendet is meghatározó, erőteljesen növekvő

Észak-Magyarország: enyhén növekvő (5. ábra).

Hasznosítása - ahogy előfordulása is - az Alföldre koncentrálódik, amit jól mutat, hogy a Tiszántúl (37\%) és a Duna-Tisza köze (29\%) együttesen a teríték 2/3-át (66\%) adja. Jelentősebb és egyre növekvő még az Észak-Dunántúl nagy lilik terítéke (23\%), míg a DélDunántúlon átlagosan csak az éves mennyiség 3\%-a, Észak-Magyarországon pedig 9\%-a esik. Az elmúlt évtizedekben nőtt az Alföldön elejtett vetési ludak részesedése a terítékböl, közülük föként a Tiszántúlon ejtettek el arányaiban egyre többet $(17 \% \rightarrow 92 \%)$. Mind a Duna-Tisza közén $(7 \% \rightarrow 90 \%)$, mind a Dél-Dunántúlon $(4 \% \rightarrow 50 \%)$ erőteljes teríték és teríték részarány növekedésnek vagyunk tanúi. Észak Magyarország szerepe általában elhanyagolható, hiszen részesedése rendszerint $0-7 \%$ közötti hullámzást mutat, egyes években azonban megnőhet részesedés (1996: 15\%; 2003: 16\%)(7. ábra).
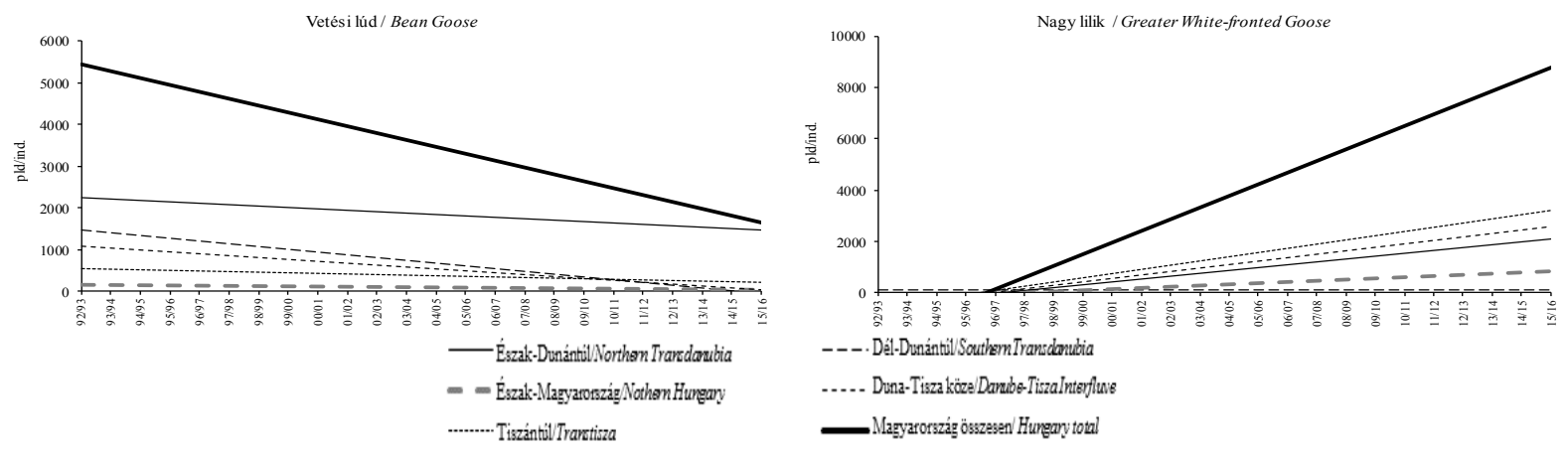

5. ábra: A vetési lúd és a nagy lilik teríték regionális trendjei Magyarországon

Figure 5: Trends of Bean Goose and Greater White-fronted Goose bag in each region in Hungary
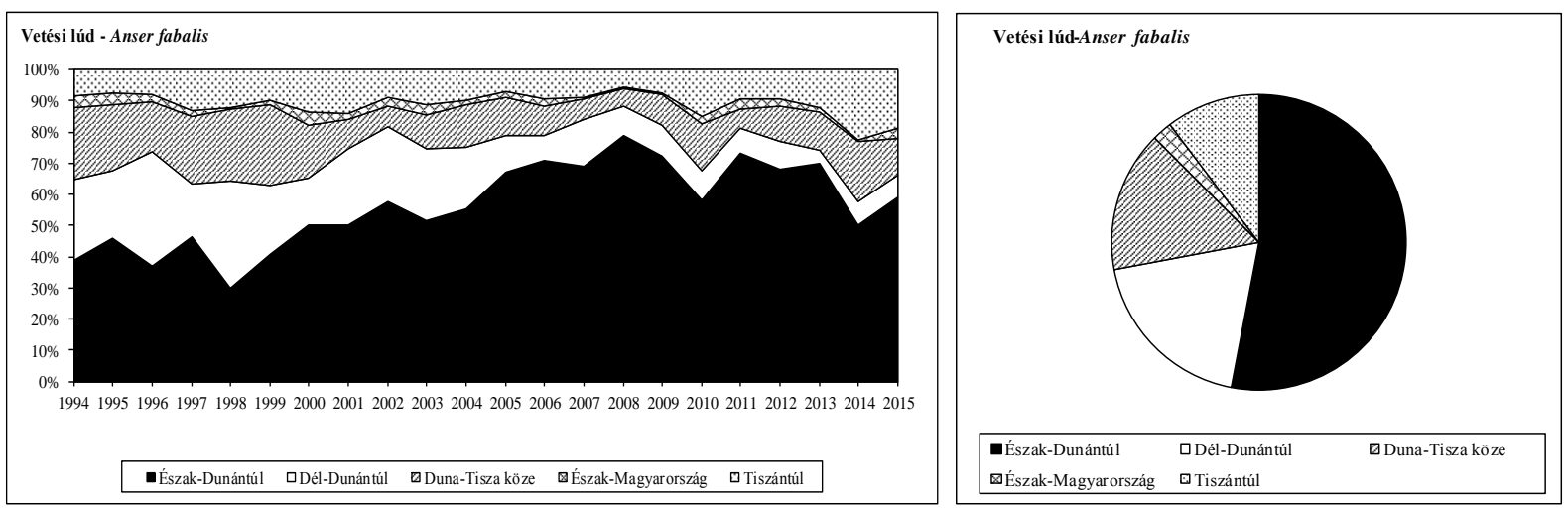

6. ábra: A vetési lúd teríték régiók szerinti megoszlása Magyarországon Figure 6: Regional distribution of Bean Goose bag in Hungary 

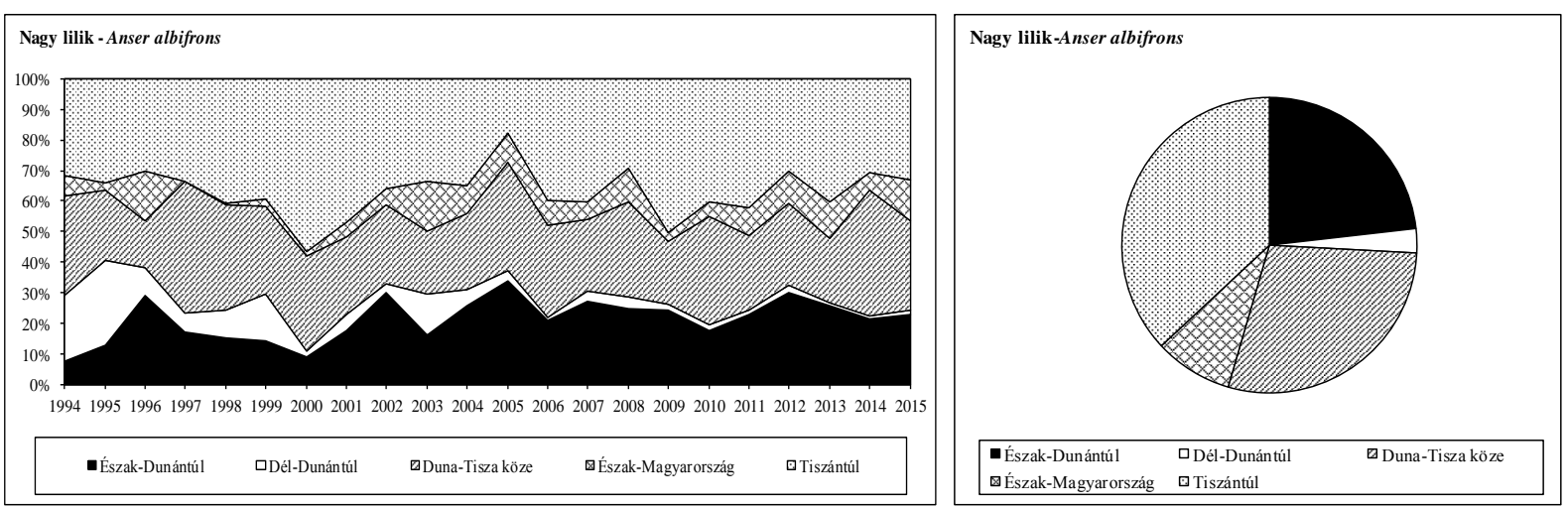

7. ábra: A nagy lilik teríték régiók szerinti megoszlása Magyarországon Figure 7: Regional distribution of Greater White-fronted Goose bag in Hungary

A két (2012 óta három) vadászható vadlúdfaj országos és régiónkénti terítékarány dinamikájában jól kimutatható a korábban gyakorlatilag (vadászok által) védett státusú nagy lilik folyamatos részarány növekedése (8. ábra; 3-4. melléklet) a vadlúd terítékben. A jogalkotás és jogalkalmazás megfelelő módon követte a pozitív állományalakulási tendenciákat, $\mathrm{s}$ a bölcs hasznosítás szellemében fokozatosan növelte a vadászati nyomást. A nagy lilik terítékbeli növekedésének mértéke a Dunától keletre igen kifejezett, attól nyugatra, illetve országos összesítésben valamennyivel szerényebb volt. Az 1994, 2004 és 2015 - a kezdeti, a közbülső és végső - évek nagy lilik teríték arányszámai mindezt jól bizonyítják:

Észak-Dunántúl

Dél-Dunántúl

Duna-Tisza köze

Tiszántúl

Észak-Magyarország

Magyarország

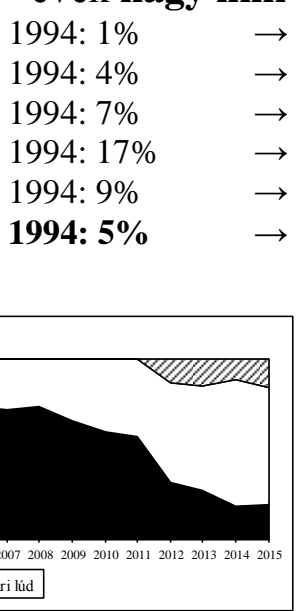

1994: $1 \%$

$4: 4 \%$

$1994:$

$\rightarrow \quad 2004: 26 \%$

$\rightarrow \quad 2004: 17 \%$

$\rightarrow \quad 2004: 58 \%$

$\rightarrow \quad 2004: 73 \%$

$\rightarrow \quad 2004: 83 \%$

$\rightarrow \quad 2004: 43 \%$
$\rightarrow \quad 2015: 65 \%$
$\rightarrow \quad 2015: 38 \%$
$\rightarrow \quad 2015: 77 \%$
$\rightarrow \quad 2015: 79 \%$
$\rightarrow \quad 2015: 73 \%$
$\rightarrow \quad$ 2015: $73 \%$
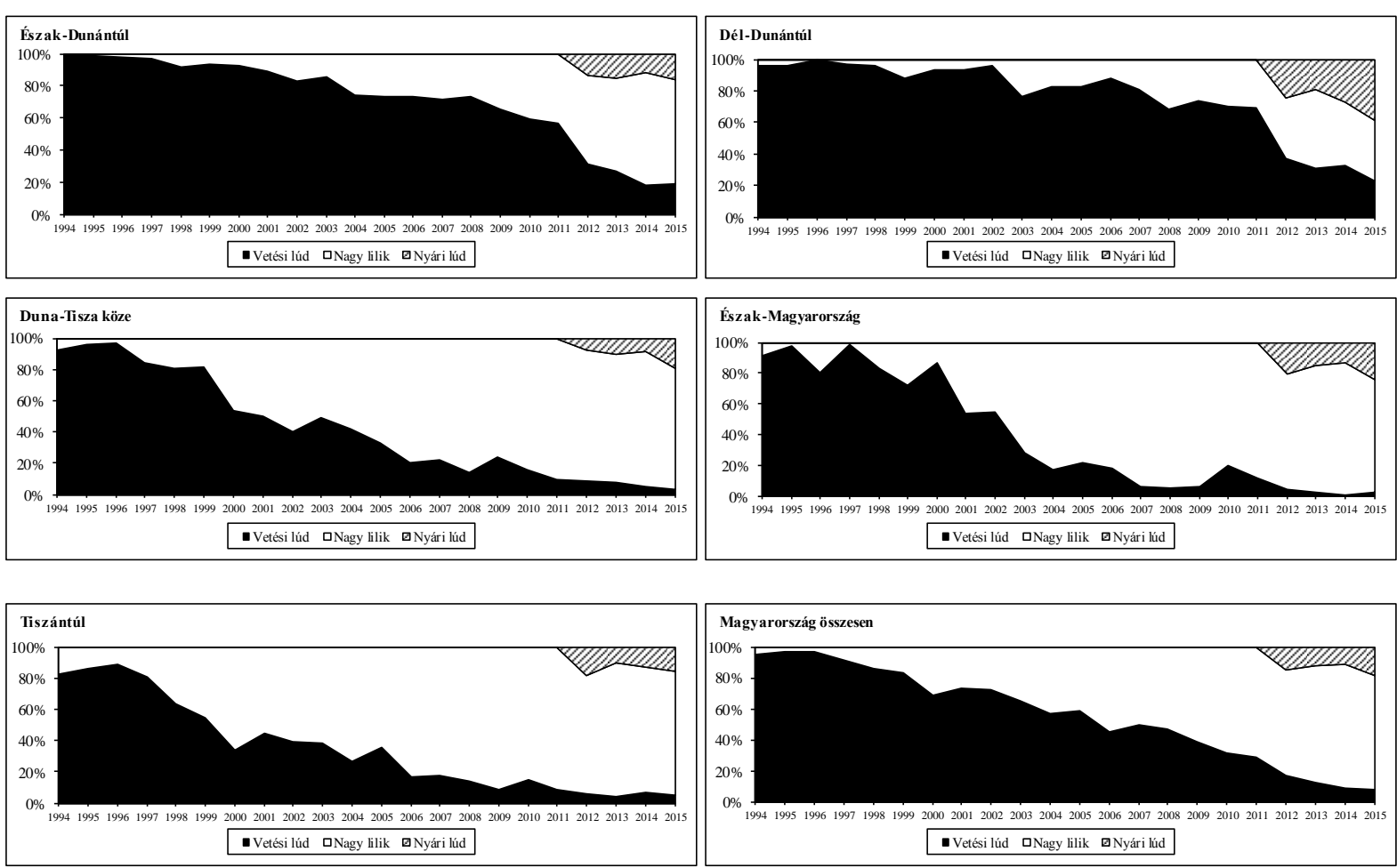

8. ábra: A vadászható vadlúdfajok regionális és országos terítékarányainak dinamikája Figure 8: Ratio of huntable goose species in the bag on regional and national level 
A vadlúdfajok korábban bemutatott területi differenciálódása jól megmutatkozik a terítékben is, úgy, ahogy azt már korábban kimutattuk (FARAGÓ, 1995a). A nagy lilik dunántúli terítékarány növekedése egyrészt a faj vonuló és telelő területeinek nyugatra tolódását, másrészt a vetési lúd állományok csökkenéséből származó terítékveszteségeket is visszatükrözi.

A NYÁRI LÚD 2012 óta vadászható terítékét négy vadászidény alapján érdemben nem tudjuk még értékelni. A négy idény nyári lúd terítékének értéke 2012: 1800 pd; 2013: 1752 pd; 2014: 1513 pd és 2015: 2677 pd volt, ami rendre 14, =\%-a, 12,6\%-a, 11,5\%-a és 18,7\%-a volt az országos vadlúd terítéknek. A számlálások eredményeit ismerve kijelenthető, hogy a teríték biztosan a 15\%-os kritikus érték alatti, tehát fenntartható hasznosítást jelent.

Hasznosítása - ahogy előfordulása is - az Észak-Dunántúlra és a Tiszántúlra koncentrálódik, amit jól mutat, hogy az Észak-Dunántúl (30\%) és a Tiszántúl (30\%) együttesen a teríték közel 2/3-át $(60 \%)$ adja. A Duna-Tisza közének még nagyobb a részesedése (21\%), de Észak-Magyarországon csak a teríték 13\%-a,, míg a Dél-Dunántúlon $5 \%$ esett.

\subsection{A VADRÉCÉK ÉS A SZÁRCSA VADÁSZATA}

A vadréce teríték a 19. század végén csak alkalmanként haladta meg az 50000 pd-t. A 20. század elején e fajcsoportnál is magasabb hasznosítási eredmények voltak kimutathatók, 1913-ban 99156 pd-t hoztak terítékre. Ez az érték sokáig a legmagasabb hasznosítás volt, hiszen az 1930-as években 76980 pd, az 1960-as években 51451 pld volt a csúcs (FARAGÓ, 2009; STERBETZ, 1972). Az 1970-1990 közötti időszak apró megtorpanásokkal jelentős terítéknövekedést mutatott, ami az 1989. évi 277000 pd-nyal érte el maximumát. Ezt követően határozott visszaesés volt tapasztalható, s az 1990-es években 60 000-80 000 pd-os tartományban változott az elejtett kacsák száma. A domináns faj mindenkor a tőkés réce volt (FARAGÓ, 1982a; CSÁNYI, 1996)(9. ábra).
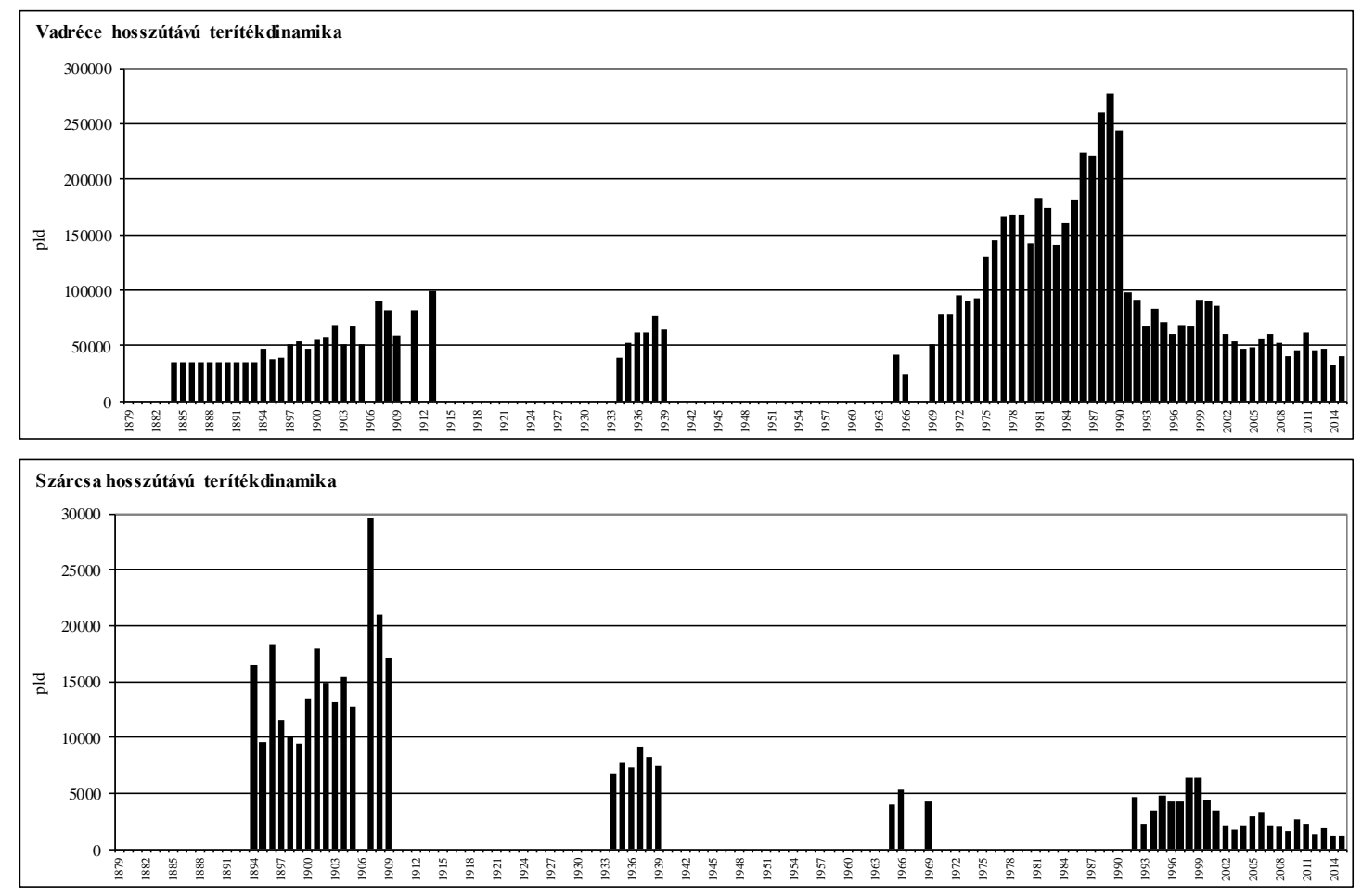

9. ábra: A réce és szárcsa teríték alakulása Magyarországon az 1884-2015 közötti 131 évben Figure 9: Bag dynamics of ducks and Eurasian Coot in Hungary over 131 years between 1884 and 2015 
Ugyanez a helyzet a szárcsával is. E fajból a század első felében 13-20.000 pld-t, az 1930-as években 6-9000 pd-t, az 1960-as évek második felében 4-5000 pd-t lőttek (FARAGÓ, 2009; STERBETZ, 1972)(9. ábra).

A TŐKÉS RÉCE terítékének trendje a vizsgált időszakban erős csökkenést mutatott, a vizsgált időszak végére, a korábbinak mintegy felére esett vissza (1992: 90711 pd $\rightarrow$ 1999: 91122 pd $\rightarrow$ 2004: 47009 pd $\rightarrow 2010:$ pd $\rightarrow$ 2015: pd) (4. ábra; 5. melléklet).

\section{Regionális trend}

Eszak-Dunántúl: enyhén csökkenő

Dél-Dunántúl: enyhén csökkenő

Duna-Tisza köze: enyhén csökkenö

Tiszántúl: magasabb szinten, de szintúgy enyhén csökkenő

Észak-Magyarország: enyhén csökkenő (10. ábra).
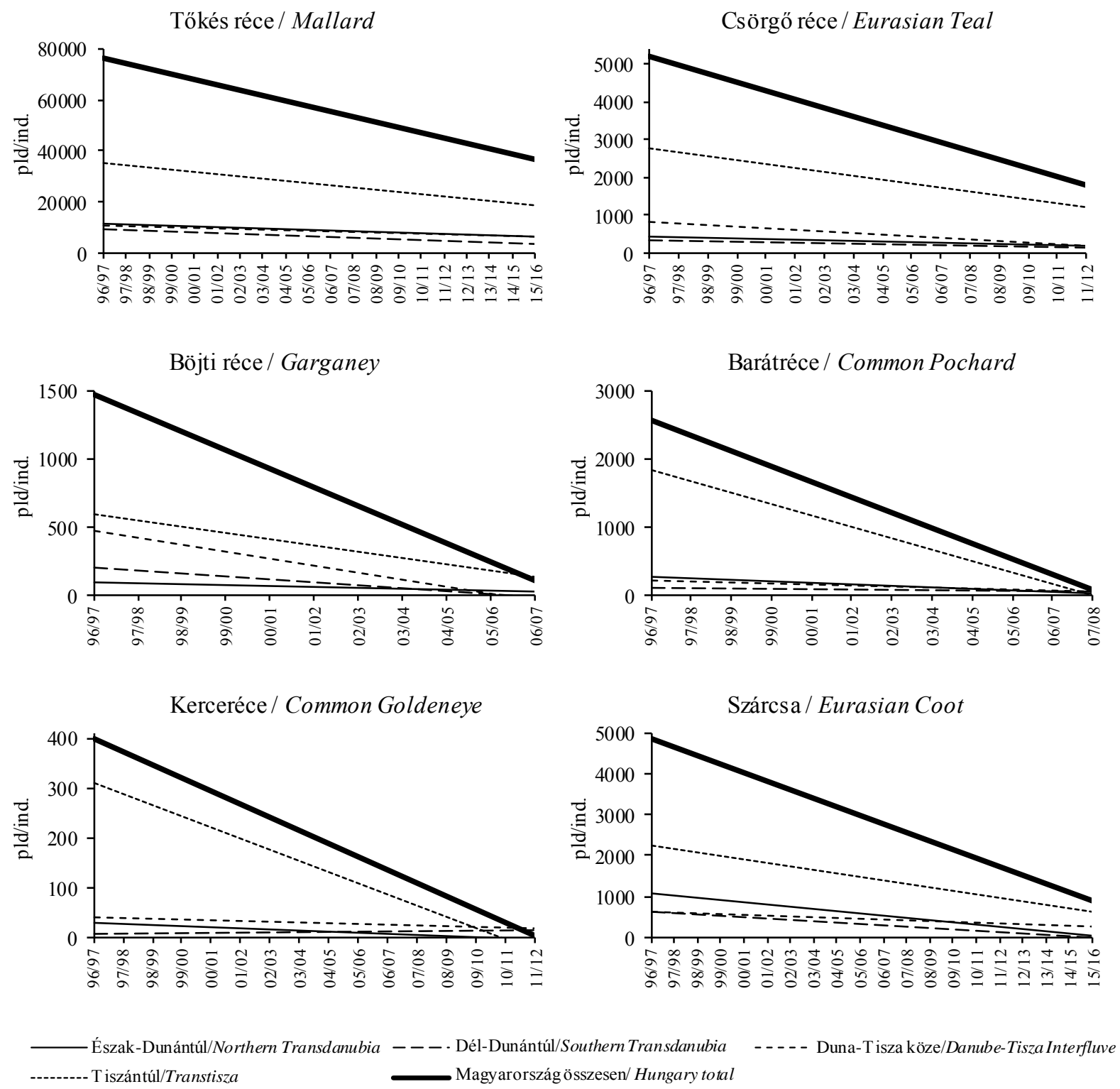

10. ábra: A vadászható récefajok és a szárcsa teríték trendjei Magyarországon Figure 10: Trends of bag of huntable duck species in each region in Hungary 
Hasznosítása - ahogy előfordulása is - az Alföldre koncentrálódik, amit jól mutat, hogy a Tiszántúl (48\%) és a Duna-Tisza köze (15\%) együttesen a teríték csaknem 2/3-át (63\%) adja. Nagyjából a Duna-Tisza közéhez hasonló arányú a maradék 3 régió részesedése a tőkés réce országos terítékéből: Észak-Dunántúl - 15\%, Dél-Dunántúl - 12\%-a, Észak-Magyarország 10\%. Az elmúlt évtizedben hullámzó módon (37-57\%), de csökkent a Tiszántúlon elejtett tőkés récék részesedése a terítékből. Az Észak-Magyarországon elejtettek aránya szerényen csökkent, az Észak Dunántúlon, a Dél-Dunántúlon és a Duna-Tisza közén elejtettek arányai ugyancsak hullámzó módon - de állandóságot mutattak (11. ábra).
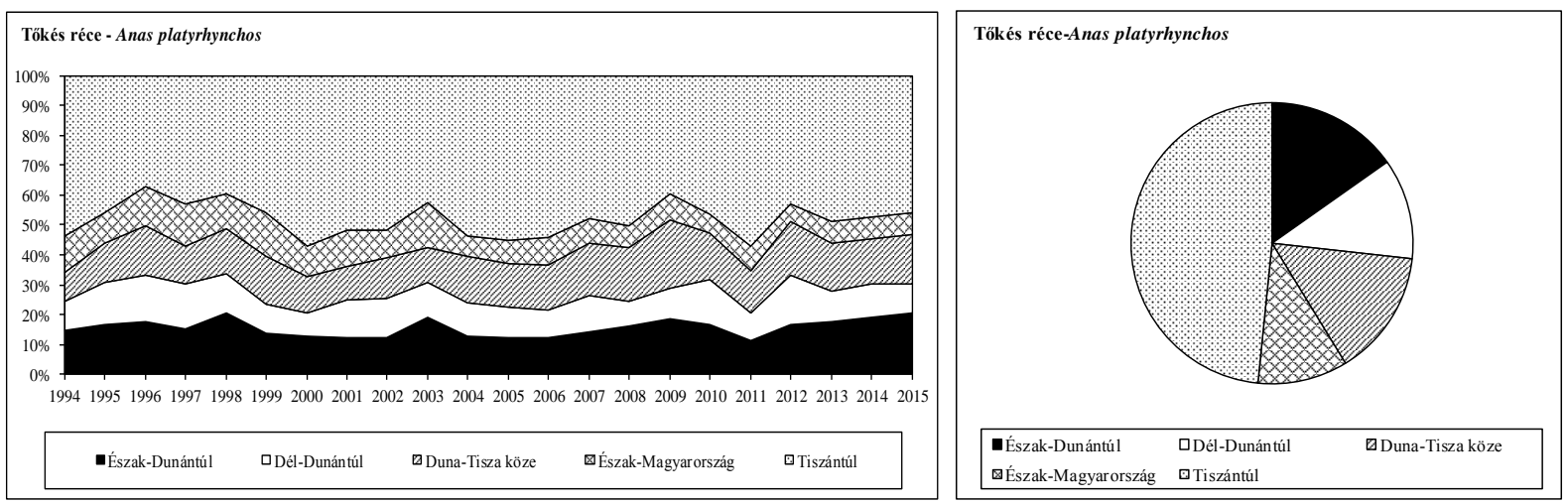

11. ábra: A tőkés réce teríték régiók szerinti megoszlása Magyarországon Figure 11: Regional distribution of Mallard's bag in Hungary

A CSÖRGÖ RÉCE - amely 2011-ig volt vadászható faj - terítékének trendje a vizsgált időszakban határozott csökkenést mutatott, védelmének bevezetéséig a korábbinak mintegy harmadára esett vissza (1992: 5857 pd $\rightarrow$ 2001: 6657 pld $\rightarrow$ 2004: 2177 pld $\rightarrow$ 2011:1927) (4. ábra; 6. melléklet).

\section{Regionális trend}

Észak-Dunántúl: enyhén csökkenő

Dél-Dunántúl: enyhén csökkenő

Duna-Tisza köze: alacsony szinten enyhén csökkenő - olykor kiugró éves értékkel

Tiszántúl: magasabb szinten, de szintúgy enyhén csökkenő

Észak-Magyarország: alacsony szinten erősen csökkenő (10. ábra).

Hasznosítása - ahogy előfordulása is - az Alföldre koncentrálódik, amit jól mutat, hogy a Tiszántúl (54\%) és a Duna-Tisza köze (15\%) együttesen a teríték 2/3-át (69\%) adja. A DunaTisza közéhez hasonló arányú az észak-magyarországi régió (15\%) részesedése a csörgő réce országos terítékéből. A Dunántúl csörgő réce terítéke szerényebb (16\%), egyenletesen oszlik meg Észak-Dunántúl - 9\%, és Dél-Dunántúl - 7\% között. A vizsgált periódus első évtizedében jelentősen nőtt (1994: 39\% $\rightarrow 2004: 71 \%)$ a Tiszántúlon elejtett csörgő récék részesedése a terítékből, majd védetté nyilvánításig újra visszaesett (2011: 58\%). Történt ez annak ellenére, hogy országos terítéke csökkent, ami a többi régió erőteljesebb csökkenésre vezethető vissza. Az Észak-Dunántúlon és a Dél-Dunántúlon elejtettek arányai szerény, a Duna-Tisza közén és Észak Magyarországon terítékre hozottak arányai erősebb csökkenést mutattak (12. ábra). 

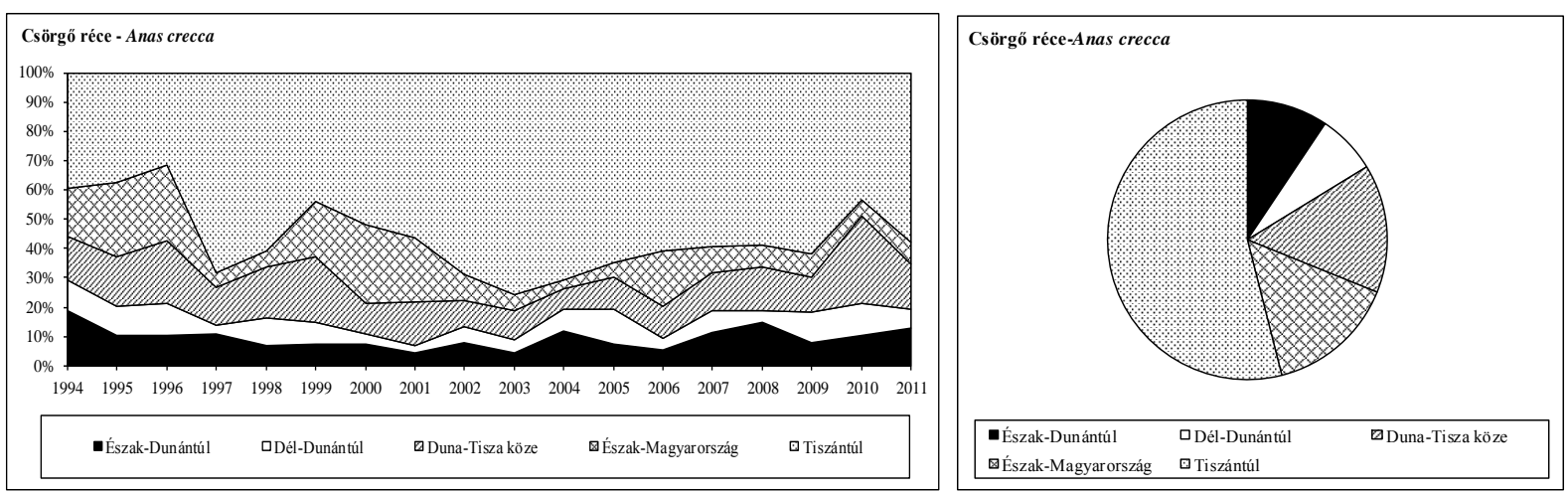

12. ábra: A csörgő réce teríték régiók szerinti megoszlása Magyarországon Figure 12: Regional distribution of Eurasian Teal's bag in Hungary

A BÖJTI RÉCE - amely 2006-ig volt vadászható faj - a vizsgált időszakban igen erős csökkenést mutatott, a korábbinak mintegy ötödére esett vissza (1992: $1407 \mathrm{pd} \rightarrow 2004: 189$ $\mathrm{pd} \rightarrow$ 2006: 187 pd) (4. ábra; 7. melléklet). A csökkenő állománydinamika és a teríték csökkenése tette szükségessé kíméletének egész éves vadászati tilalmi idővel való megerősítését.

\section{Regionális trend}

Észak-Dunántúl: enyhén csökkenő

Dél-Dunántúl: enyhén csökkenő

Duna-Tisza köze: erösen csökkenő

Tiszántúl: erősen csökkenő

Észak-Magyarország: erősen csökkenő (10. ábra).

Hasznosítása - ahogy előfordulása is - az Alföldre koncentrálódott, amit jól mutat, hogy a Tiszántúl (44\%) és a Duna-Tisza köze (23\%) együttesen a teríték 2/3-át (67\%) adta.
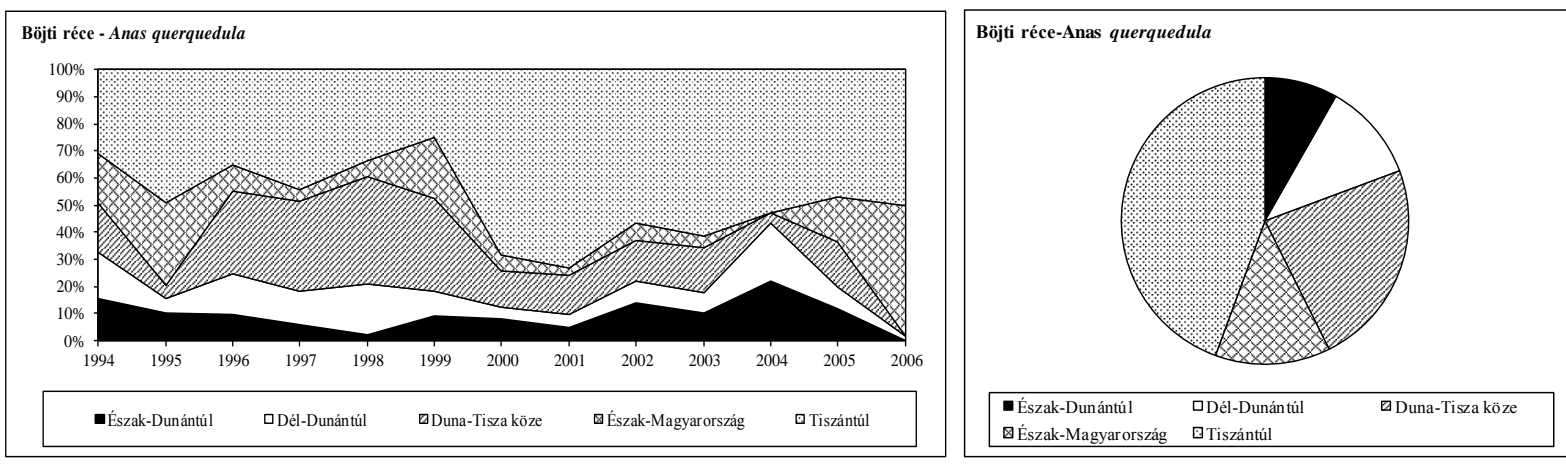

13. ábra: A böjti réce teríték régiók szerinti megoszlása Magyarországon Figure 13: Regional distribution of Garganey's bag in Hungary

A maradék 3 régió részesedése a böjti réce országos terítékéböl hasonló, bár közülük kétségtelenül Észak-Magyarország (13\%) kiemelkedik (Észak-Dunántúl - 8\%, Dél-Dunántúl - 11\%). A vadászhatóság utolsó évtizedében jelentősen nőtt a Tiszántúlon és ÉszakMagyarországon (Alföld északi pereme) elejtett böjti récék részesedése a terítékböl. A DunaTisza közén elejtettek aránya erősen, a Dél-Dunántúlon és Észak Magyarországon elejtettek arányai szerényen csökkentek, míg az Észak-Dunántúlon terítékre hozottaké szerényen nőtt (13. ábra).

A BARÁTRÉCE - amely 207-ig volt vadászható faj - terítékének trendje a vizsgált időszakban igen erős csökkenést mutatott, a korábbinak mintegy tizedére esett vissza (1994: 
4098 pd $\rightarrow$ 1999: 3075 pd $\rightarrow 2004: 450$ pd $\rightarrow 2007: 448$ pd)(4. ábra; 8. melléklet). Mint látható, terítékdinamikája különösen az ezredforduló után mutat drámai képet.

\section{Regionális trend}

Észak-Dunántúl: szerényen csökkenő

Dél-Dunántúl: szerényen csökkenő

Duna-Tisza köze: szerényen csökkenő

Tiszántúl: drámai, igen erős csökkenő

Észak-Magyarország: erős csökkenő (10. ábra).

Hasznosítása az Alföldre koncentrálódik, amit jól mutat, hogy a Tiszántúl (70\%) és a DunaTisza köze (8\%) együttesen a teríték csaknem 4/5-ét (78\%) adja. A maradék 3 régió közül kiemelhető Észak-Dunántúl (12\%), míg nagyjából hasonló arányú a Dél-Dunántúl (5\%) és Észak-Magyarország (6\%) együttes részesedése a barátréce országos terítékéből. A vizsgált időszakban erőteljesen csökkent a Tiszántúlon, gyengébben az Észak-Dunántúlon, határozottan az Észak-Magyarországon elejtett barátrécék részesedése a terítékböl. A DélDunántúlon és a Duna-Tisza közén arányai határozott növekedést mutattak (14. ábra).
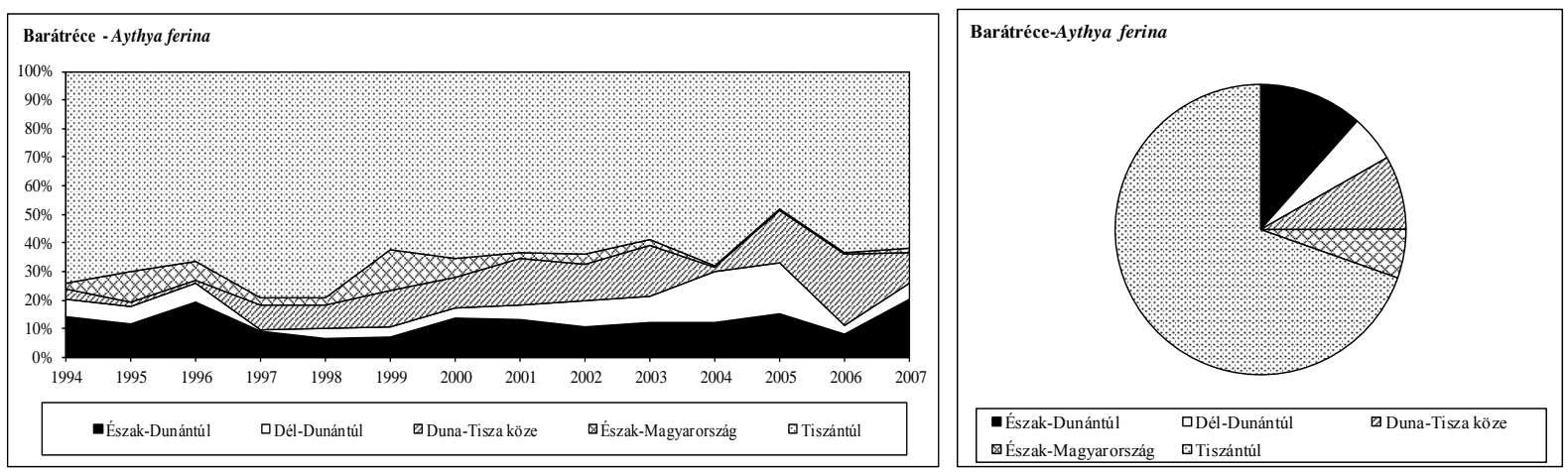

14. ábra: A barátréce teríték régiók szerinti megoszlása Magyarországon Figure 14: Regional distribution of Common Pochard's bag in Hungary

A KERCERÉCE - amely 2011-ig volt vadászható faj - terítékének trendje a vizsgált időszakban erős csökkenést mutatott, vadászhatóságának utolsó évtizedében, a korábbinak mintegy tizedére esett vissza (1994: $324 \mathrm{pd} \rightarrow$ 1999: $248 \mathrm{pd} \rightarrow$ 2004: $59 \mathrm{pd} \rightarrow$ 2011: $30 \mathrm{pd}$ ) (4. ábra; 9. melléklet). Végül gyakorlatilag jelentőségét vesztette vadászata.

\section{Regionális trend}

Észak-Dunántúl: alacsony szinten stabil

Dél-Dunántúl: alacsony szinten stabil

Duna-Tisza köze: alacsony szinten stabil

Tiszántúl: igen erösen csökkenő

Észak-Magyarország: enyhén csökkenő (10. ábra).

Hasznosítása - meglepő módon - az Alföldre koncentrálódott, amit jól mutat, hogy a Tiszántúl (72\%) és a Duna-Tisza köze (13\%) együttesen a teríték csaknem 9/10-ét (85\%) adja. Egymáshoz viszonyítva nagyjából hasonló arányú a maradék 3 régió részesedése a kerceréce országos terítékéből: Észak-Dunántúl - 5\%, Dél-Dunántúl - 5\%-a, ÉszakMagyarország - 4\%. Az elmúlt évtizedben valamelyest nőtt a Duna-Tisza közén és a DélDunántúlon elejtett kercerécék részesedése a terítékből, ami a Tiszántúl igen erős részesedés csökkenésére vezethető vissza. Az Észak-Dunántúlon és Észak Magyarországon elejtettek arányai nem mutatnak határozott trendet, hullámzóak (15. ábra). 

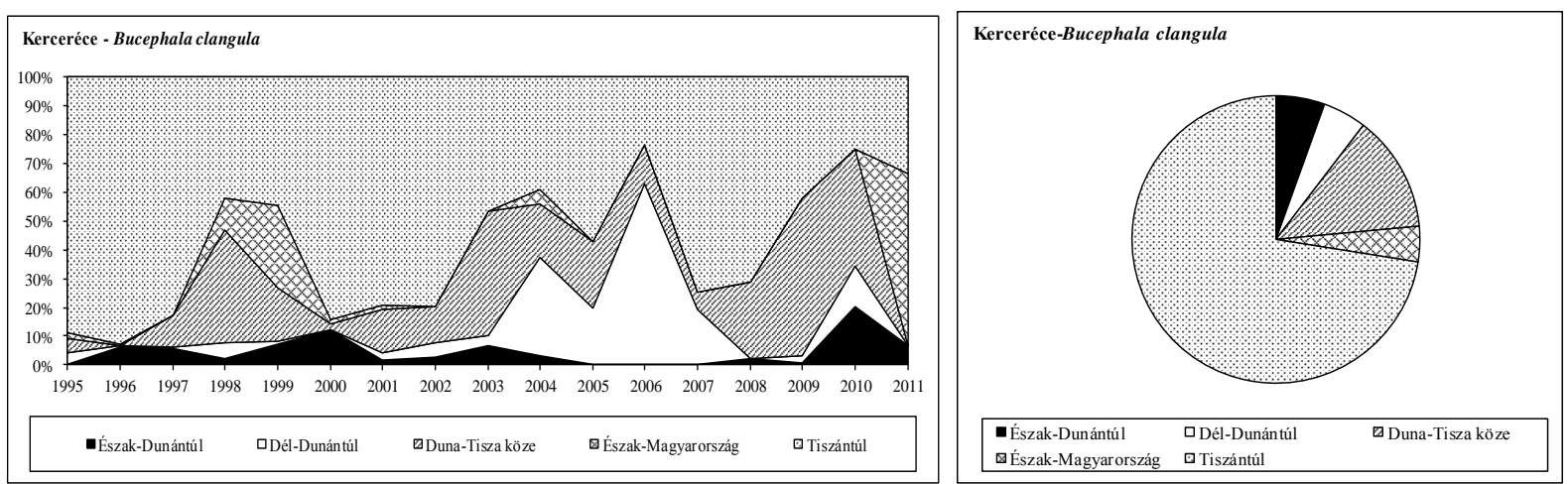

15. ábra: A kerceréce teríték régiók szerinti megoszlása Magyarországon Figure 15: Regional distribution of Common Goldeneye's bag in Hungary

A SZÁRCSA terítékének trendje a vizsgált időszakban erős csökkenést mutatott, két évtized alatt mintegy ötödére esett vissza (1992: 4626 pd $\rightarrow$ 1999: 6407 pd $\rightarrow$ 2004: 2101 $\mathrm{pd} \rightarrow$ 2010: $2702 \mathrm{pd} \rightarrow 2015: 1181 \mathrm{pd})$ (4. ábra; 10. melléklet).

\section{Regionális trend}

Észak-Dunántúl: csökkenő

Dél-Dunántúl: enyhén csökkenő

Duna-Tisza köze: enyhén csökkenő

Tiszántúl: erösen csökkenö

Észak-Magyarország: enyhén csökkenő (10. ábra).

Hasznosítása az Alföldre koncentrálódik, amit jól mutat, hogy a Tiszántúl (47\%) és a DunaTisza köze (15\%) együttesen a teríték csaknem 2/3-át (62\%) adja. A maradék 3 régió részesedései közül kiemelkedik az Észak-Dunántúl (21\%) a szárcsa országos terítékéből. Sorrendben azt a Dél-Dunántúl (11\%) és Észak-Magyarország (5\%) követi. Az elmúlt évtizedben lényegesen nőtt a Tiszántúlon, szolidabban a Duna-Tisza közén elejtett szárcsák részesedése a terítékből. Az Észak-Dunántúlon és Észak-Magyarországon elejtettek aránya jelentősen, a Dél-Dunántúlon elejtettek arányai szerényen csökkentek (16. ábra).
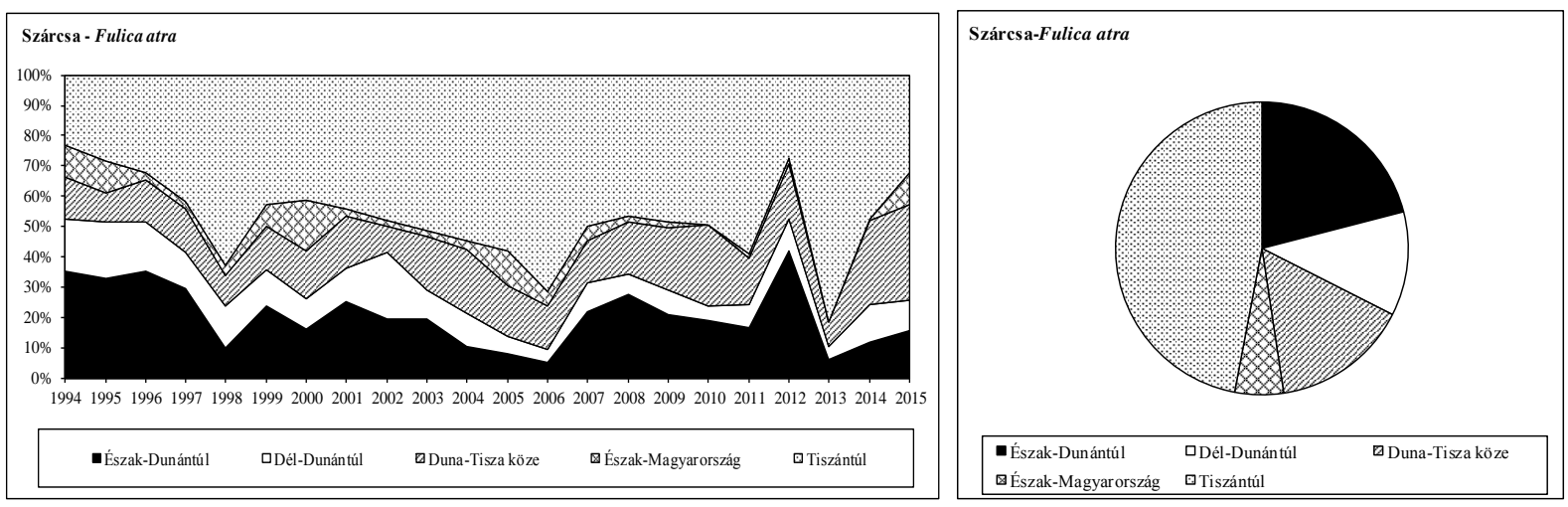

16. ábra: A szárcsa teríték régiók szerinti megoszlása Magyarországon Figure 16: Regional distribution of Eurasian Coot's bag in Hungary

A vadászható récefajok és a szárcsa országos és régiónkénti terítékarány dinamikájában jól kimutatható a tőkés réce korábban többször megállapított (FARAGÓ \& RITTER, 1998; 1999; FARAGÓ et al., 2001; 2002a; 2002b; 2003; LEHOCZKI \& CSÁNYI, 2006; 2007; 2008; 2009; 2010; 2012) dominanciája (17. ábra; 11-12. melléklet) a terítékben. A tőkés réce terítékbeli növekedésének mértéke a minden régióban és országosan is igen 
kifejezett, a Tiszántúlon viszont stabil volt. Az 1994, 2004 és 2015 - a kezdeti, a közbülső és végső - évek tőkés réce teríték arányszámai mindezt bizonyítják:

\begin{tabular}{|c|c|c|c|c|c|c|}
\hline \multirow[t]{6}{*}{ Tőkés réce } & Észak-Dunántúl & 1994: $81 \%$ & $\rightarrow$ & 2004: $91 \%$ & $\rightarrow$ & 2015: 98\% \\
\hline & Dél-Dunántúl & 1994: $84 \%$ & $\rightarrow$ & 2004: $91 \%$ & $\rightarrow$ & 2015: $97 \%$ \\
\hline & Duna-Tisza köze & 1994: $84 \%$ & $\rightarrow$ & 2004: $92 \%$ & $\rightarrow$ & 2015: $95 \%$ \\
\hline & Tiszántúl & 1994: $88 \%$ & $\rightarrow$ & 2004: $89 \%$ & $\rightarrow$ & 2015: $98 \%$ \\
\hline & Észak-Magyarország & 1994: $88 \%$ & $\rightarrow$ & 2004: $96 \%$ & $\rightarrow$ & 2015: $96 \%$ \\
\hline & Magyarország & 1994: $86 \%$ & $\rightarrow$ & 2004: $90 \%$ & $\rightarrow$ & 2015: $97 \%$ \\
\hline \multirow[t]{6}{*}{ Csörgö réce } & Észak-Dunántúl & 1994: $7 \%$ & $\rightarrow$ & 2004: $4 \%$ & $\rightarrow$ & 2011: $3 \%$ \\
\hline & Dél-Dunántúl & 1994: $6 \%$ & $\rightarrow$ & 2004: $3 \%$ & $\rightarrow$ & 2011: $2 \%$ \\
\hline & Duna-Tisza köze & 1994: $8 \%$ & $\rightarrow$ & 2004: $2 \%$ & $\rightarrow$ & 2011: 3\% \\
\hline & Tiszántúl & 1994: 4\% & $\rightarrow$ & 2004: $5 \%$ & $\rightarrow$ & 2011: $3 \%$ \\
\hline & Észak-Magyarország & 1994: $8 \%$ & $\rightarrow$ & 2004: $2 \%$ & $\rightarrow$ & 2011: $3 \%$ \\
\hline & Magyarország & 1994: $6 \%$ & $\rightarrow$ & 2004: $4 \%$ & $\rightarrow$ & 2011: $3 \%$ \\
\hline \multirow[t]{6}{*}{ Böjti réce } & Észak-Dunántúl & 1994: $1 \%$ & $\rightarrow$ & 2004: $1 \%$ & $\rightarrow$ & $2006: \pm 0 \%$ \\
\hline & Dél-Dunántúl & 1994: $2 \%$ & $\rightarrow$ & 2004: $1 \%$ & $\rightarrow$ & $2006: \pm 0 \%$ \\
\hline & Duna-Tisza köze & 1994: $2 \%$ & $\rightarrow$ & $2004: \pm 0 \%$ & $\rightarrow$ & $2006: \pm 0 \%$ \\
\hline & Tiszántúl & 1994: $1 \%$ & $\rightarrow$ & $2004: \pm 0 \%$ & $\rightarrow$ & $2006: \pm 0 \%$ \\
\hline & Észak-Magyarország & 1994: $2 \%$ & $\rightarrow$ & $2004: \pm 0 \%$ & $\rightarrow$ & 2006: $2 \%$ \\
\hline & Magyarország & 1994: $1 \%$ & $\rightarrow$ & 2004: $\pm 0 \%$ & $\rightarrow$ & 2006: $\pm 0 \%$ \\
\hline \multirow[t]{6}{*}{ Barátréce } & Észak-Dunántúl & 1994: $4 \%$ & $\rightarrow$ & 2004: $1 \%$ & $\rightarrow$ & 2007: $1 \%$ \\
\hline & Dél-Dunántúl & 1994: 3\% & $\rightarrow$ & 2004: $1 \%$ & $\rightarrow$ & $2007: \pm 0 \%$ \\
\hline & Duna-Tisza köze & 1994: $2 \%$ & $\rightarrow$ & $2004: \pm 0 \%$ & $\rightarrow$ & $2007: \pm 0 \%$ \\
\hline & Tiszántúl & 1994: $6 \%$ & $\rightarrow$ & 2004: $1 \%$ & $\rightarrow$ & 2007: $1 \%$ \\
\hline & Észak-Magyarország & 1994: $1 \%$ & $\rightarrow$ & $2004: \pm 0 \%$ & $\rightarrow$ & $2007: \pm 0 \%$ \\
\hline & Magyarország & 1994: $4 \%$ & $\rightarrow$ & 2004: $1 \%$ & $\rightarrow$ & 2007: $1 \%$ \\
\hline \multirow[t]{6}{*}{ Kerceréce } & Észak-Dunántúl & $1994: \pm 0 \%$ & $\rightarrow$ & $2004: \pm 0 \%$ & $\rightarrow$ & $2011: \pm 0 \%$ \\
\hline & Dél-Dunántúl & $1994: \pm 0 \%$ & $\rightarrow$ & $2004: \pm 0 \%$ & $\rightarrow$ & $2011: \pm 0 \%$ \\
\hline & Duna-Tisza köze & $1994: \pm 0 \%$ & $\rightarrow$ & $2004: \pm 0 \%$ & $\rightarrow$ & $2011: \pm 0 \%$ \\
\hline & Tiszántúl & $1994: \pm 0 \%$ & $\rightarrow$ & $2004: \pm 0 \%$ & $\rightarrow$ & $2011: \pm 0 \%$ \\
\hline & Észak-Magyarország & $1994: \pm 0 \%$ & $\rightarrow$ & $2004: \pm 0 \%$ & $\rightarrow$ & $2011: \pm 0 \%$ \\
\hline & Magyarország & 1994: $\pm 0 \%$ & $\rightarrow$ & 2004: $\pm 0 \%$ & $\rightarrow$ & 2011: $\pm 0 \%$ \\
\hline \multirow[t]{6}{*}{ Szárcsa } & Észak-Dunántúl & 1994: $7 \%$ & $\rightarrow$ & 2004: $3 \%$ & $\rightarrow$ & $2015: 2 \%$ \\
\hline & Dél-Dunántúl & 1994: 6\% & $\rightarrow$ & 2004: $4 \%$ & $\rightarrow$ & 2015: $3 \%$ \\
\hline & Duna-Tisza köze & 1994: $4 \%$ & $\rightarrow$ & 2004: $6 \%$ & $\rightarrow$ & 2015: $5 \%$ \\
\hline & Tiszántúl & 1994: $1 \%$ & $\rightarrow$ & 2004: $4 \%$ & $\rightarrow$ & 2015: $2 \%$ \\
\hline & Észak-Magyarország & 1994: 3\% & $\rightarrow$ & 2004: $2 \%$ & $\rightarrow$ & 2015: 4\% \\
\hline & Magyarország & 1994: $3 \%$ & $\rightarrow$ & 2004: $4 \%$ & $\rightarrow$ & 2015: 3\% \\
\hline
\end{tabular}

A récefajok és a szárcsa állománydinamikájának területi differenciálódása jól megmutatkozik a terítékben is, azaz a csörgő réce, a böjti réce, a barátréce és a kerceréce és a szárcsa állománycsökkenései leginkább a dunántúli területeket érintették, ami terítékeik csökkenéséhez, ezáltal a tőkés réce teríték arányainak relatív növekedéséhez vezetett (17. ábra). A csörgő réce, a böjti réce, a barátréce és a kerceréce állománycsökkenése - mint a jogszabályi áttekintésnél ismertettük - elvezetett vadászható faj státusok megszüntetéséhez, védetté nyilvánításához. 

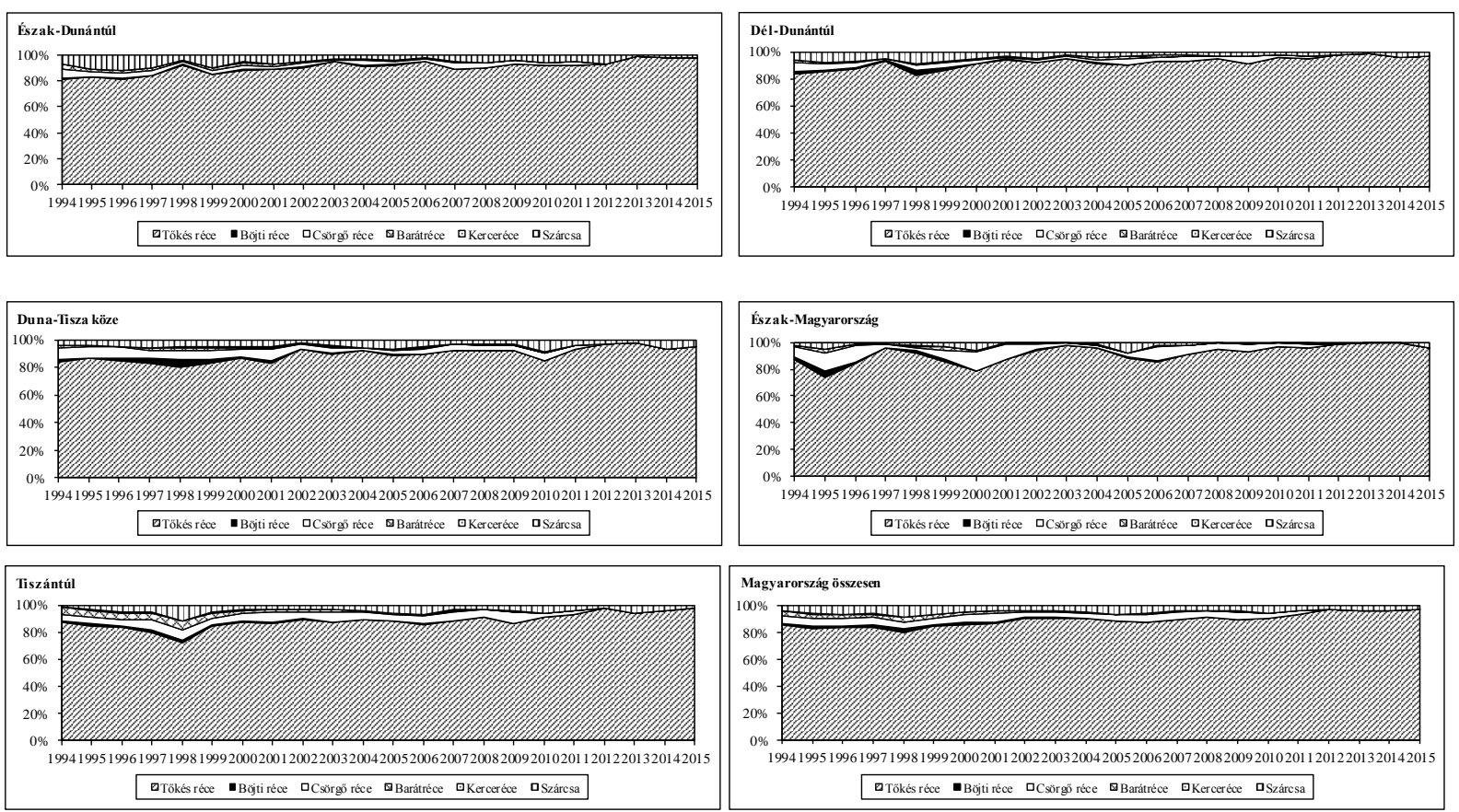

17. ábra: A vadászható récefajok és a szárcsa regionális és országos terítékarányainak dinamikája

Figure 17: Ratio of huntable duck species and Common coot in the bag on regional and national level

Végül a számadatokból az is kiderül, hogy Magyarországon, a tökés récén kívül korábban a csörgö récének (3-6\%) és a barátrécének (1-4\%) volt, a böjti récének és a kercerécének (<1\%) gyakorlatilag nem volt vadászati jelentösége. Utóbbi négy faj védetté nyilvánítása utána tőkés récén kívül, mint vízivad már csak a szárcsa vadászható, terítéknagyságban kimutatható vadászati szerepe azonban eltörpül (3-4\%) a tőkés réce mellett.

\subsection{A POPULÁCIÓ- ÉS HASZNOSÍTÁS DINAMIKA ÖSSZEHASONLÍTÓ VIZSGÁLATA}

Az állomány és terítékvizsgálatok arra is módot adnak, hogy összefüggést keressünk és találjunk az állománydinamika és a terítékdinamika között. Általánosságban elfogadhatjuk azt az alapelvet, hogy azt az állomány-teríték viszonyt tekinthetjük elfogadhatónak, amelynél az állomány növekedésével arányos a teríték változása. Ludak esetében a teríték mértéke legfeljebb az állomány 15\%-a lehet (KALCHREUTER, 1994). Az elkövetkezőkben vizsgáljuk meg fajonként, azon belül régiónként és országosan az állomány-teríték viszony harmóniáját, vagy annak hiányát!

\subsubsection{A vadlúd populációk nagysága és hasznosításuk közötti kapcsolat}

A kérdés megválaszolásához tekintsük át két, hosszú időszak óta vadászható vadlúd faj (Anser fabalis és Anser albifrons) állomány- és hasznosítás-dinamikáját (18-19. ábra). Összevetésünk azért is korrekt lesz, mert a vadludak esetében a MAGYAR VADLÚD MONITORING csaknem teljes állományadatokat szolgáltat. Első megállapításunk az, hogy a két diagram képe a terítékdinamikát illetően csaknem azonos, annak ellenére, hogy a vetési lúd állománya drasztikusan lecsökkent, míg a nagy liliké többszörösére növekedett. Amíg a nagylilik növekvő vonuló-telelő példányszáma maga után vonta a teríték növekedését, addig $a$ vetési lúd egyedszám csökkenése nem tükrözödött vissza a teríték csökkenésében is. Ez utóbbi 
anomália olyan mértékü - s ezt már a faj tárgyalása során is megállapítottuk - amely fizikailag is lehetetlen.

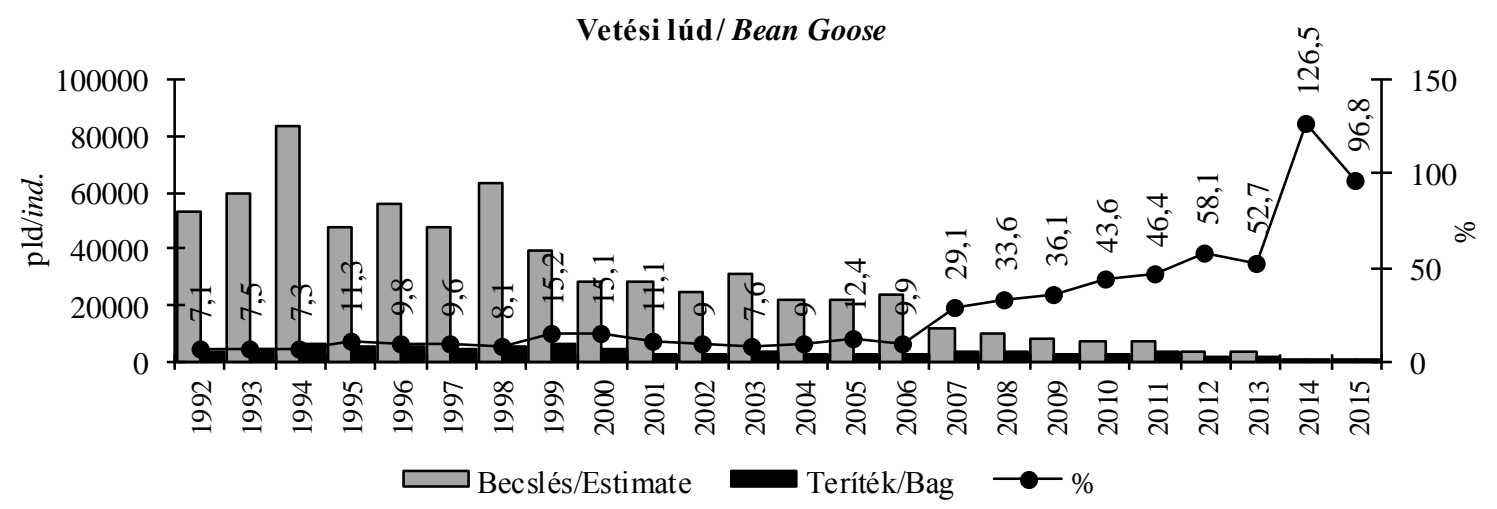

18. ábra: A vetési lúd becsült állománynagysága és terítéke a vadászati idényben Magyarországon, 1992/1993-2015/2016

Figure 18: The estimated population size and the hunting bag of Bean Goose in the hunting season between 1992/1993 and 2015/2016

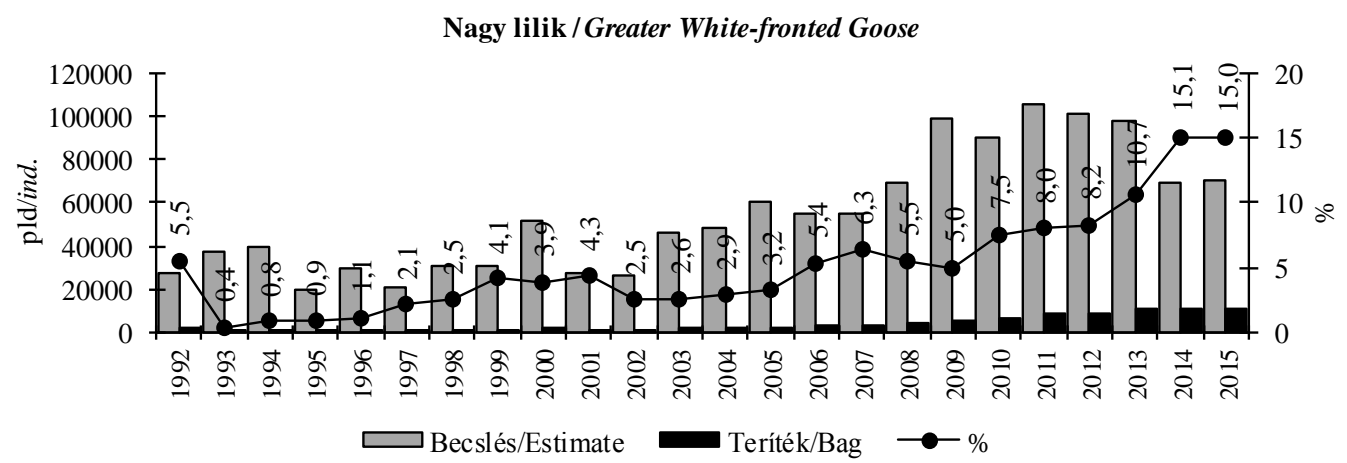

19. ábra: A nagy lilik becsült állománynagysága és terítéke a vadászati idényben Magyarországon, 1992/1993-2015/2016

Figure 19: The estimated population size and the hunting bag of Greater White-fronted Goose in the hunting season between 1992/1993 and 2015/2016

A 100\%-ot meghaladó hasznosítás lehetetlen, mint azt KALCHREUTER, (1994) által lefektetésre került, a hasznosítás fenntartható módon legfeljebb az állomány $15 \%$-át érintheti. Fenti anomália magyarázatát a terítékstatisztika területi megoszlása adja. Az alföldi területekről kerül ki a statisztikák szerint a vetési ludak átlagosan $\mathbf{2 7 \% - a}$, onnan ahol a MAGYAR VADLÚD MONITORING megfigyelései szerint már az utolsó évtizedben gyakorlatilag eltünt a vetési lúd.

Jól látszik az 1993 előtti időszakban, hogy a napi teríték limit nem tompította a mennyiségi követést. Jól érzékelhető az is, hogy a nagy lilik becsült és terítékre hozott mennyisége hogyan változott a vadászati szabályozás pozitív hatásaként. Vizsgáljuk meg ezen összefüggéseket az egyaránt korrekt állomány és terítékadatokkal jellemezhető 1992-2015 közötti, egyúttal jelenős változásokat mutató időszakban!

A vetési lúd esetében egyértelmüen szoros $\left(R^{2}=0,6988\right.$ illetve $\left.R^{2}=0,8782\right)$ összefüggés adódott az állomány és a teríték nagyság-változása között országos szinten és a DélDunántúlon. Egyedül az észak-magyarországi régióban nem vonta maga után a vetési lúd állomány növekedése a teríték növekedését. (20. ábra; 13-14. és 23a. melléklet). 
Mielőtt a hasznosításra vonatkozó végső konklúziót kimondanánk, még egy további mutató vizsgálata elkerülhetetlen, nevezetesen a becsült tetőző mennyiség és a teríték közti arány. A vetési lúd esetében ezt elvileg kizárólag a napi terítékkorlátozás szabályozza. Eredményeként az ezredforduló időszakáig 7,1-15,2\%-os hasznosítási arányt lehetett kimutatni (18. ábra). Ennek a felső értékei ugyan magasak voltak, de az ilyen arányú hasznosítást még a populáció - átlagos költési viszonyok mellett realizálódó szaporodási rátával - képes kompenzálni. Abban az időben egyértelmű tendencia volt, hogy a teríték limit mellett az egyre nagyobb egyedszám, egyre alacsonyabb hasznosítási arányt von maga után.
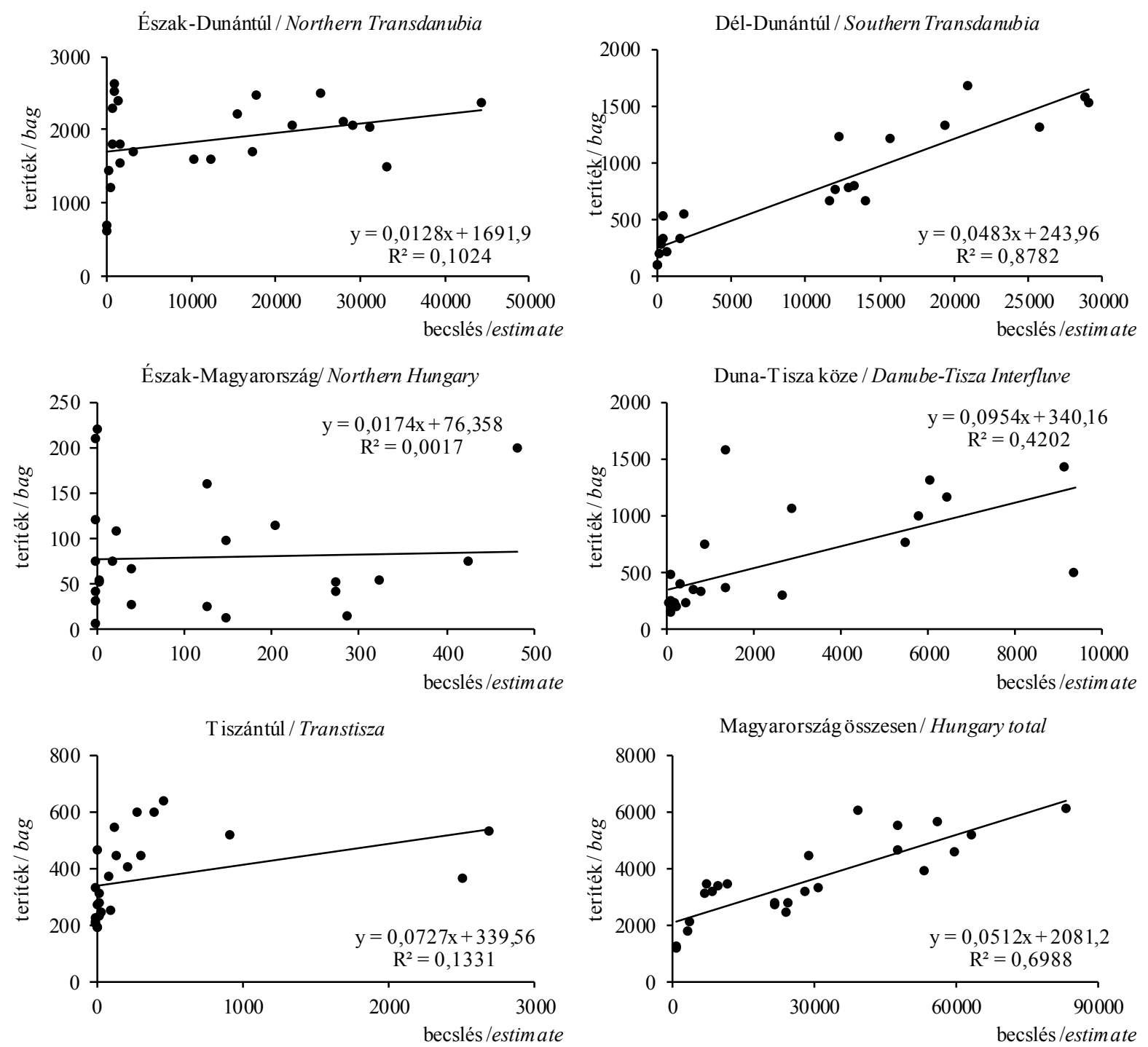

20. ábra: A vetési lúd becsült állománynagysága és terítéke közötti összefüggés a vadászati idényben Magyarországon, 1992/1993-2015/2016

Figure 20: Relation between the estimated population size and the hunting bag of Bean Goose in the hunting season between 1992/1993 and 2015/2016

Az is igaz azonban, hogy az állománycsökkenés mellett állandósult vadászati nyomás, a napi terítékkorlát fenntartása mellett is a túlhasznosításnak potenciális veszélyét hordozta, amit már az 1999-es és a 2000-es vadászidény terítékarányai $(15,2 \%$ ill. $15,1 \%)$ is mutattak (21. ábra). Az ilyen esetekben a napi teríték limit mellett, szükség lehet az általános mennyiségi korlátok, alkalmasint regionális szintü bevezetésére, amihez az állománynagyság aktuális ismerete elengedhetetlen. A MAGYAR VADLÚD MONITORING észlelései alapján már az 
ezredforduló óta jeleztük a faj kárpát-medencei vonuló és telelő állományainak vészes fogyását, erre azonban intézkedés nem történt. A statisztikákban rögzített teríték aránya elérte a számlált mennyiség 50\%-át majd 100\%-át is meghaladta. Természetesen ez csak úgy volt lehetséges, ha a nagy lilik teriték egy része (a napi teriték limitet kijátszva) vetési lúdként lett feljegyezve és lejelentve.

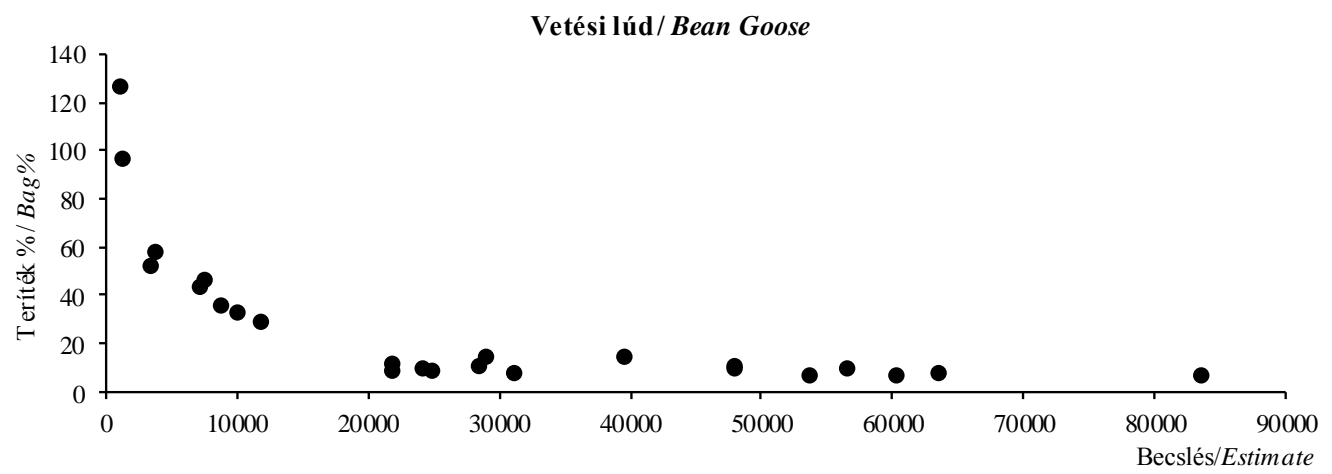

\section{1. ábra: A vetési lúd teríték aránya a becsült állománynagysághoz viszonyítva a vadászati idényben Magyarországon, 1992-2016}

Figure 21: The proportion of the hunting bag according to the estimated population of Bean Goose in the hunting season between 1992-2016

A nagy lilik esetében országos szinten ugyancsak egyértelmü összefüggés adódott $\left(\mathrm{R}^{2}=0,6939\right)$ az állománynövekedés és a teríték nagyság változása között (22. ábra; 15-16. és 23a. melléklet). Az egyes régiókban, ahol kis területen koncentrálódva, illetve a Duna-Tisza közén és a Tiszántúlon, ahol ugyan nagy elterjedésben, de azon belül ugyancsak koncentrálódva jelent meg a nagy lilik, jól érvényesült a napi teríték limit hatása, azaz az állománynövekedés a hasznositási arány stagnálását, vagy csökkenését eredményezte.

A nagy lilik vadászata során a teríték nagyságát az 1990-es években alapvetően a károkozás veszélyével arányos engedélykiadás határozta meg, amelyet tovább szigorított az ebben az esetben is érvényes napi terítéklimit. Ennek megfelelően az 1992-ben érvényes 5,5\%-os hasznosítás az 1993-ban életbelépő szigorítás után 0,4\%-ra esett vissza, ami aztán lassan emelkedett 4,3\%-ig (19. ábra). Ennek a mértéke (23. ábra) akkor messze alacsonyabb volt a faj átlagos szaporodási teljesítményénél.

A nagy lilik vadászatra érvényes, 1994-ben visszatért hagyományos (értsd vadászidény és napi teríték limit) vadászati rend mellett - tekintettel a korábbi tapasztalatokra - fokozott figyelmet kellett fordítani a sérülékeny faj hasznosításának monitorozására.

A Kárpát-medencében vonuló és telelő nagy lilik populáció folyamatos emelkedése mint láttuk - a vadászati terítéknövekedést is maga után vonta. A hasznosítás aránya 2013/2014-es idényben elérte a 10\%-ot, a 2014/15-ös és a 2015/2016-os vadászidényben

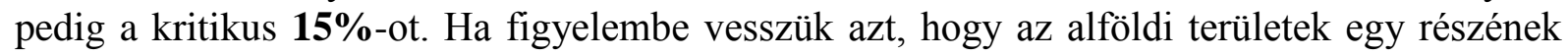
vetési lúdként nyilvántartott terítéke ugyancsak nagy lilik, akkor a hasznosítás aránya nemkívánatosan meghaladja a 15\%-ot. Történik ez akkor, amikor további regionális korlátok is érvényben vannak a Tiszántúlon a kis lilik védelme érdekében.

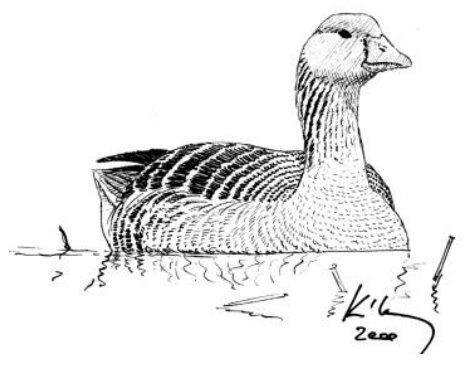



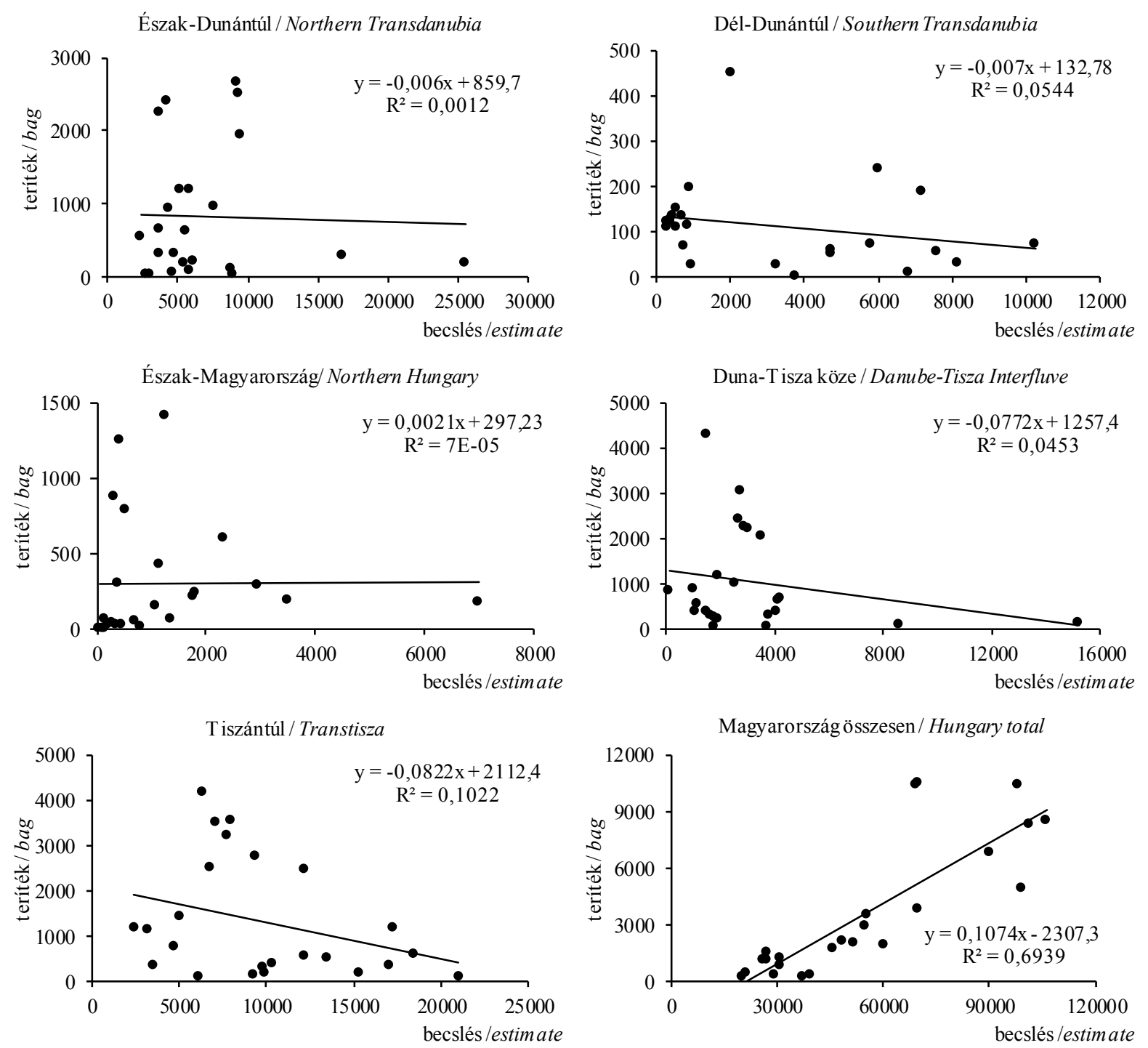

22. ábra: A nagy lilik becsült állománynagysága és terítéke közötti összefüggés a vadászati idényben Magyarországon, 1992/1993-2015/2016

Figure 22: Relation between the estimated population size and the hunting bag of Greater Whitefronted Goose in the hunting season between 1992/1993-2015/2016

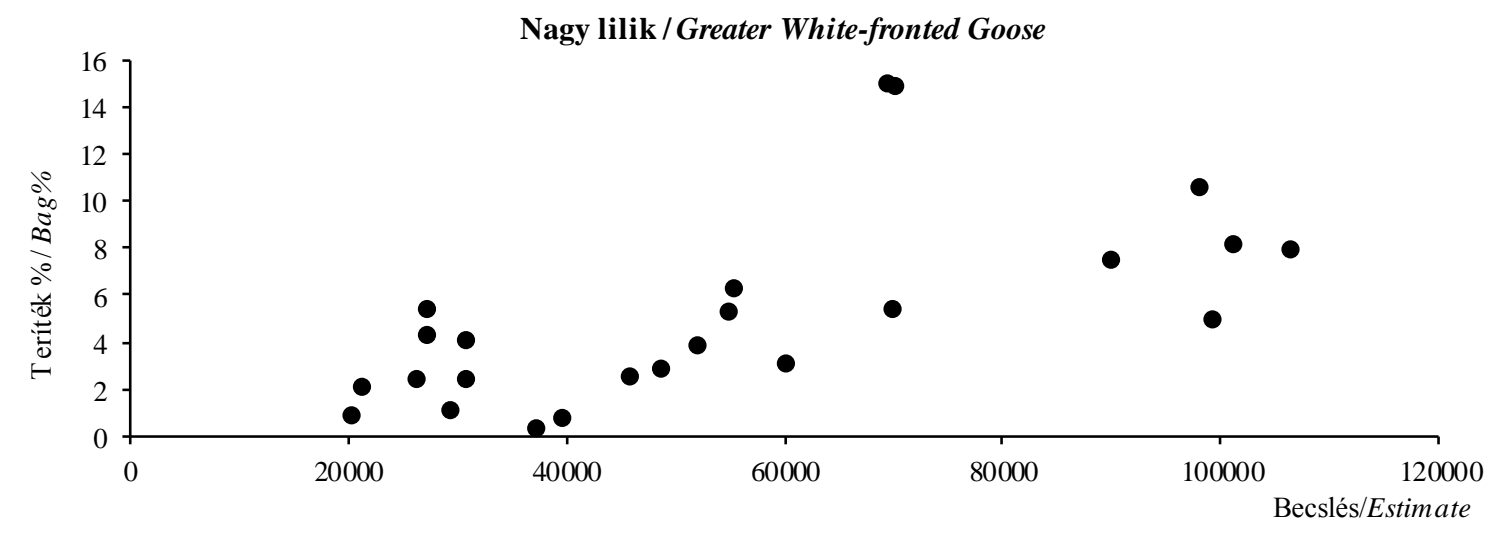

23. ábra: A nagy lilik teríték aránya a becsült állománynagysághoz viszonyítva a vadászati idényben Magyarországon, 1992/1993-2015/2016

Figure 23: The proportion of the hunting bag according to the estimated population size of Greater White-fronted Goose in the hunting season between 1992/1993 and 2015/2016 
A 2012 óta vadászható nyári lúd terítékét négy vadászidény alapján érdemben nem tudjuk még értékelni. A négy terítékértékről - 2012: 1800 pd; 2013: 1752 pd; 2014: 1513 pd és 2015: 2677 pd - ismételve kijelenthető, hogy biztosan a 15\%-is kritikus érték alatti, tehát fenntartható hasznosítást jelent.

Ha a régóta vadászható két vadlúdfaj mennyiségi és hasznosítási adatait összesítve értékeljük, akkor kimutatható a két faj eltérö állomány- és terítékalakulása közötti kompenzáló hatás, amely végső soron a magyar vadlúd teríték növekedését jelenti a növekvő nagy lilik és vadászhatóvá váló nyári lúd állományok következményeként. $A \boldsymbol{z}$ elemzésekböl az is egyértelmüen kijelenthetö, hogy a növekedést elösegítette a szigorú vadászati szabályozás.

Az 1993-ban életbe lépett vadlúdvadászati rendelkezések azonban nemcsak a vadászati módokban és a napi, személyenkénti teríték limitben teremtettek új helyzetet Magyarországon, hanem az ú.n. kíméleti területek hálózatának kialakításával is. Javaslatunkra akkor 10, ma 40 ilyen terület van Magyarországon, olyan, ahol magán a területen és $1 \mathrm{~km}$-es körzetében vadászati tilalom van. Ezzel a módszerrel - a vadlúd védelem szempontjai szerint elengedhetetlen módon - valamennyi fontos éjszakázó-hely kímélete megvalósult. E területeknek a vadludak igényeit kielégítő ökológiai adottságait ráadásul élöhely-gazdálkodási módszerekkel szükség szerint fokozzák (lásd 6. fejezet).

Mindezek alapján megállapítható, hogy Magyarországon a nagy lilik és a nyári lúd védelme és vadászata a bölcs hasznositás szellemében történik, a vetési lúd esetében a hivatalos statisztikákban megjelenített vadászati terítéke eléri a becsült létszámot, ami lehetetlen és tarthatatlan, a becslések alapján országos terítéke maximum 300-350 példány lehetne!!

\subsubsection{A réce valamint szárcsa populációk nagysága és hasznosításuk közötti kapcsolat}

A vizsgálatok első körében megszemléljük, hogy a becslés és a teríték diszperziója milyen képet mutat az egyes fajok esetében, majd ezt követően elemezni fogjuk, hogy az állománynövekedés milyen mértékü hasznosítást generált, illetve azt, hogy a teríték arányban áll-e a növekedéssel. A vizsgálatokat az 1996/1997-től azon szezonokig végeztük el, ameddig az adott fajok vadászhatók voltak. E kérdéssel a túlhasznosítás lehetőségét, illetve a jogi szabályozás eredményességét kontrolláljuk.

A TÖKÉS RÉCE esetében a becslés és a teríték összehasonlító területi diszperziója az alábbi képet mutatja:

$\begin{array}{lcc} & \text { Becslés } & \text { Teríték } \\ \text { Észak-Dunántúl } & 25 \% & 15 \% \\ \text { Dél-Dunántúl } & 11 \% & 12 \% \\ \text { Duna-Tisza köze } & 12 \% & 15 \% \\ \text { Észak-Magyarország } & 0 \% & 10 \% \\ \text { Tiszántúl } & 53 \% & 48 \%\end{array}$

Mivel Észak-Magyarországon nincsenek monitorozott jelentősebb vizek, viszont a kisebb vizes élőhelyeken lőnek tőkésrécét, ezért a faj részesedése a terítékből $10 \%$ jelentősen meghaladja az észlelt 0\% megfigyelési arányt. A Dél-Dunántúlt és a Duna-Tisza közét kivéve mindenütt a becsült értékkel arányos (annál kisebb arányú) a teríték.

A becslés és teríték értékelhető (4 régióra vonatkoztatott) regressziós kapcsolatai szerint közepesen szoros $\left(\mathrm{R}^{2}=0,4931\right.$; illetve $\left.\mathrm{R}^{2}=0,5294\right)$ összefüggés mutatkozott az állomány és a teríték nagyság-változása (24. ábra; 17. és 23b. melléklet) között országos szinten, a Dél-Dunántúlon. Más régiókban is maga után vonja az állomány növekedése a tőkés réce teríték növekedését, de a növekedés mértéke jóval szerényebb, s statisztikailag sem olyan erős a kapcsolat (Észak-Dunántúl: $\mathrm{R}^{2}=0,0963$; Duna-Tisza köze: $\mathrm{R}^{2}=0,2090$; Tiszántúl: 
$\mathrm{R}^{2}=0,1650$. Ott tehát, ahol a legtöbb tőkés réce jelenik meg nagy területen, a magas kínálat ellenére a terítéklimit nem engedi a magasabb lelövési arányokat.
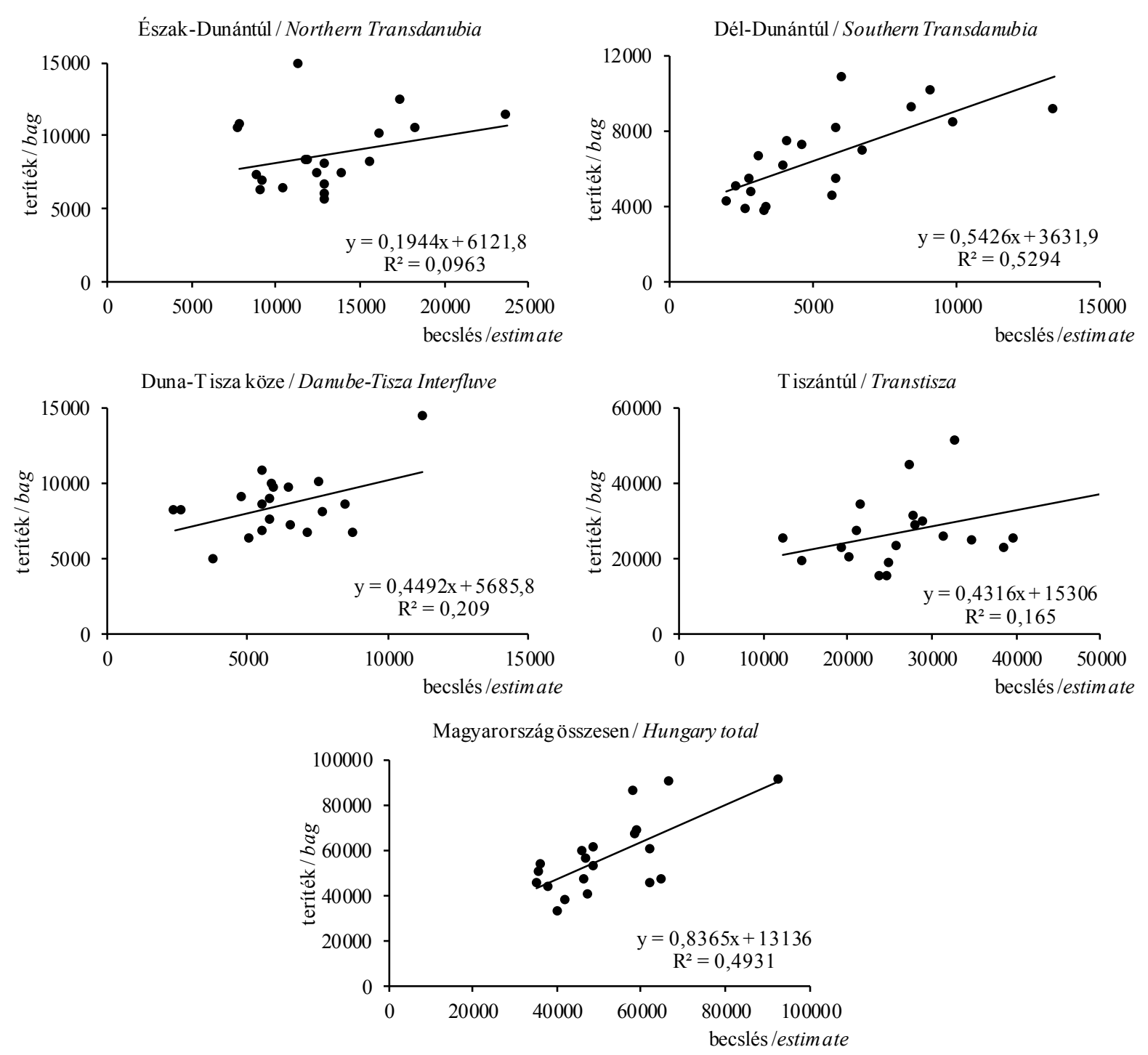

24. ábra: A tőkés réce becsült állománynagysága és terítéke közötti összefüggés a vadászati idényben Magyarországon, 1996-2016

Figure 24: Relation between the estimated population size and the hunting bag of Mallard in the hunting season between 1996/1997 and 2015/2016

A CSÖRGŐ RÉCE esetében a becslés és a teríték 1996-2012 közötti összehasonlító területi diszperziója az alábbi képet mutatja:

$\begin{array}{lcc} & \text { Becslés } & \text { Teríték } \\ \text { Észak-Dunántúl } & 24 \% & 9 \% \\ \text { Dél-Dunántúl } & 9 \% & 7 \% \\ \text { Duna-Tisza köze } & 10 \% & 15 \% \\ \text { Észak-Magyarország } & 0 \% & 15 \% \\ \text { Tiszántúl } & 59 \% & 54 \%\end{array}$

Mivel Észak-Magyarországon nincsenek monitorozott jelentősebb vizek, viszont a koncentráltabb vizes élőhelyeken (pl. Tisza-tó vidéke) lőnek csörgő récét, ezért a faj 
részesedése a terítékből $15 \%$ jelentősen meghaladta az észlelt $0 \%$ megfigyelési arányt. A Dunántúlon és a Tiszántúlon kevesebbet löttek, mint becsültek, ami annak a torzításnak a részbeni következménye, hogy Észak-Magyarországon nincs becslés.

A becslés és teríték értékelhető (4 régióra vonatkoztatott) regressziós kapcsolatai szerint közepesen szoros $\left(\mathrm{R}^{2}=0,5399\right.$ illetve $\left.\mathrm{R}^{2}=0,4903\right)$ összefüggés mutatkozott az állomány és a teríték nagyság-változása (25. ábra; 18. és 23b. melléklet) között az Észak-Dunántúlon és a Duna-Tisza közén. A Dél-Dunántúlon és a Tiszántúlon nem volt szignifikánsan kimutatható kapcsolat $\left(\mathrm{R}^{2}=0,0129\right.$ és $\left.\mathrm{R}^{2}=0,0641\right)$. Ugyanez volt megállapítható országos szinten is $\left(\mathrm{R}^{2}=0,1946\right)$. A Tiszántúlon ráadásul a gyenge kapcsolatot növekvő példányszám : csökkenő teríték relációban mutattuk ki. A csörgő réce állomány emelkedése csak bizonyos határig vonta maga után a teríték növekedését. Ott, ahol a sok csörgö réce jelent meg, illetve országos szinten - a magas kínálat ellenére - a teríték szolid növekedését vagy csökkenést mutattunk ki, azaz a terítéklimit e fajnál sem engedte a magasabb hasznosítási arányokat.

A BÖJTI RÉCE esetében a becslés és a teríték 1996-2007 közötti időszakra vonatkozó összehasonlító területi diszperziója az alábbi képet mutatja:

$\begin{array}{lcc} & \text { Becslés } & \text { Teríték } \\ \text { Észak-Dunántúl } & 39 \% & 8 \% \\ \text { Dél-Dunántúl } & 7 \% & 11 \% \\ \text { Duna-Tisza köze } & 9 \% & 23 \% \\ \text { Észak-Magyarország } & 0 \% & 13 \% \\ \text { Tiszántúl } & 45 \% & 44 \%\end{array}$

Az Észak-Dunántúlon jóval kevesebbet lőnek, mint becsülnek, ami annak a következménye, hogy a Fertő tónál megjelenő nagy mennyiség a védelem miatt nem hasznosított. A DunaTisza közén éppen fordított a helyzet, ami a halastavak környékének magasabb hasznosítására utal.

A becslés és teríték értékelhető (4 régióra vonatkoztatott) regressziós kapcsolatai szerint egyértelmüen nagyon szoros $(\mathrm{r}=0,8032)$, illetve szoros $(\mathrm{r}=0,7582)$ összefüggés mutatkozott az állomány és a teríték nagyság-változása (26. ábra; 19. és 23b. melléklet) között a Duna-Tisza közén és országos szinten. A Duna-Tisza közén a szoros kapcsolat a fenntarthatóhoz képest erősebb hasznosítást mutat, amit a becslés : hasznosítás viszonyának egyenlötlensége is megerősít. A Dél-Dunántúl és a Tiszántúl esetében a kapcsolat szorossága kis fokú volt, míg az Észak-Dunántúlon nem volt szignifikáns összefüggés kimutatható. A többi területen az összefüggések a korlátozások hatásosságát igazolták.

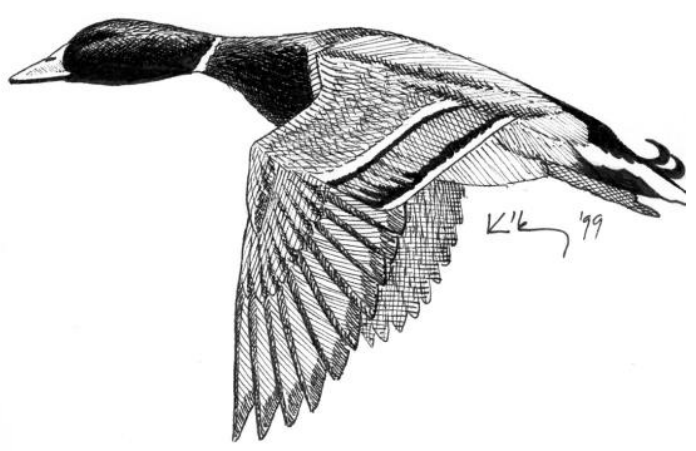



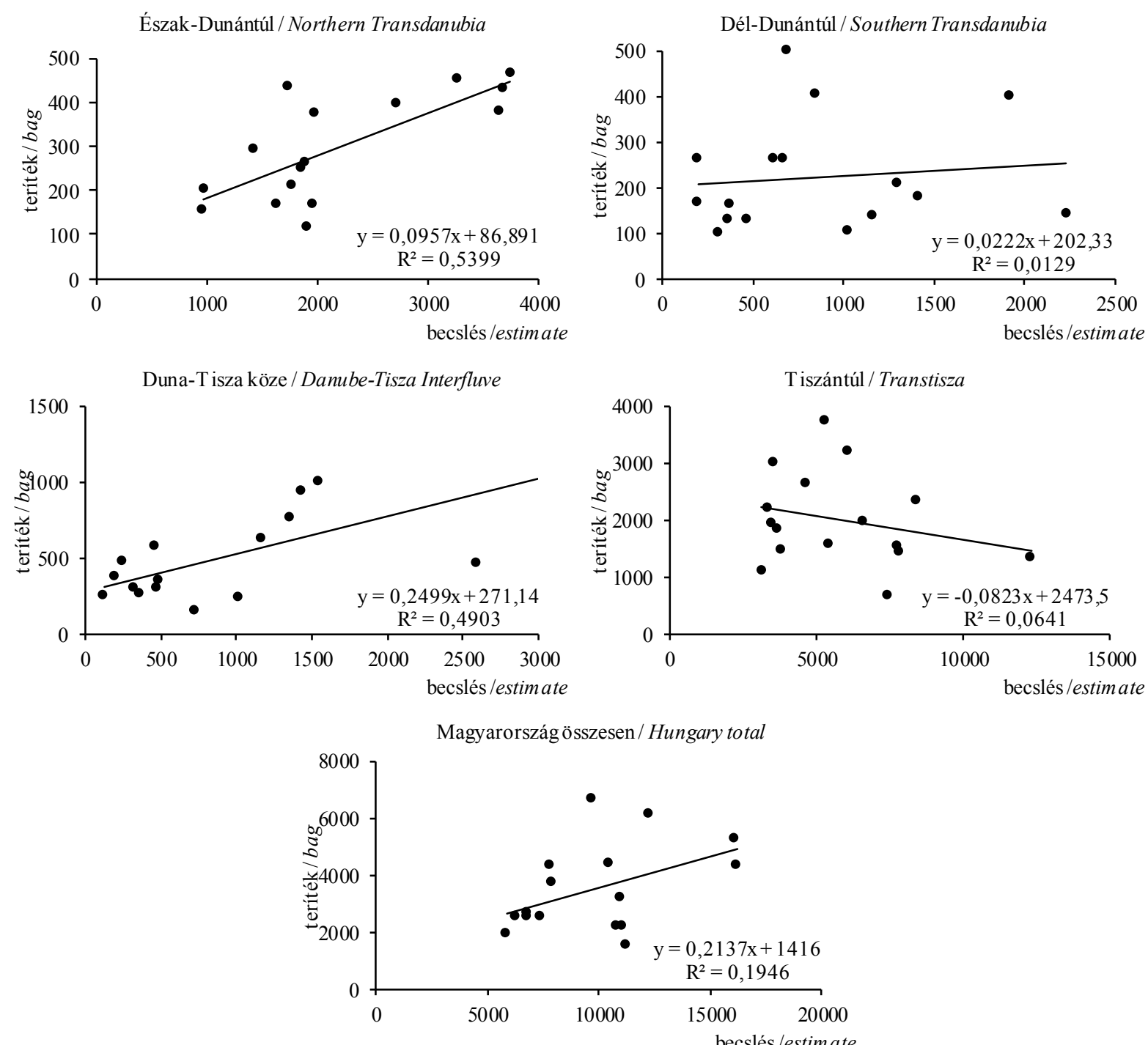

25. ábra: A csörgő réce becsült állománynagysága és terítéke közötti összefüggés a vadászati idényben Magyarországon, 1996-2012

Figure25: Relation between the estimated population and the hunting bag of Eurasian Teal in the hunting season between 1996 and 2012

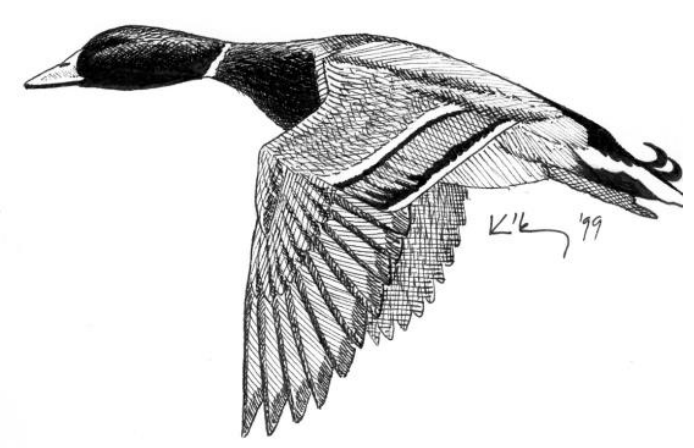



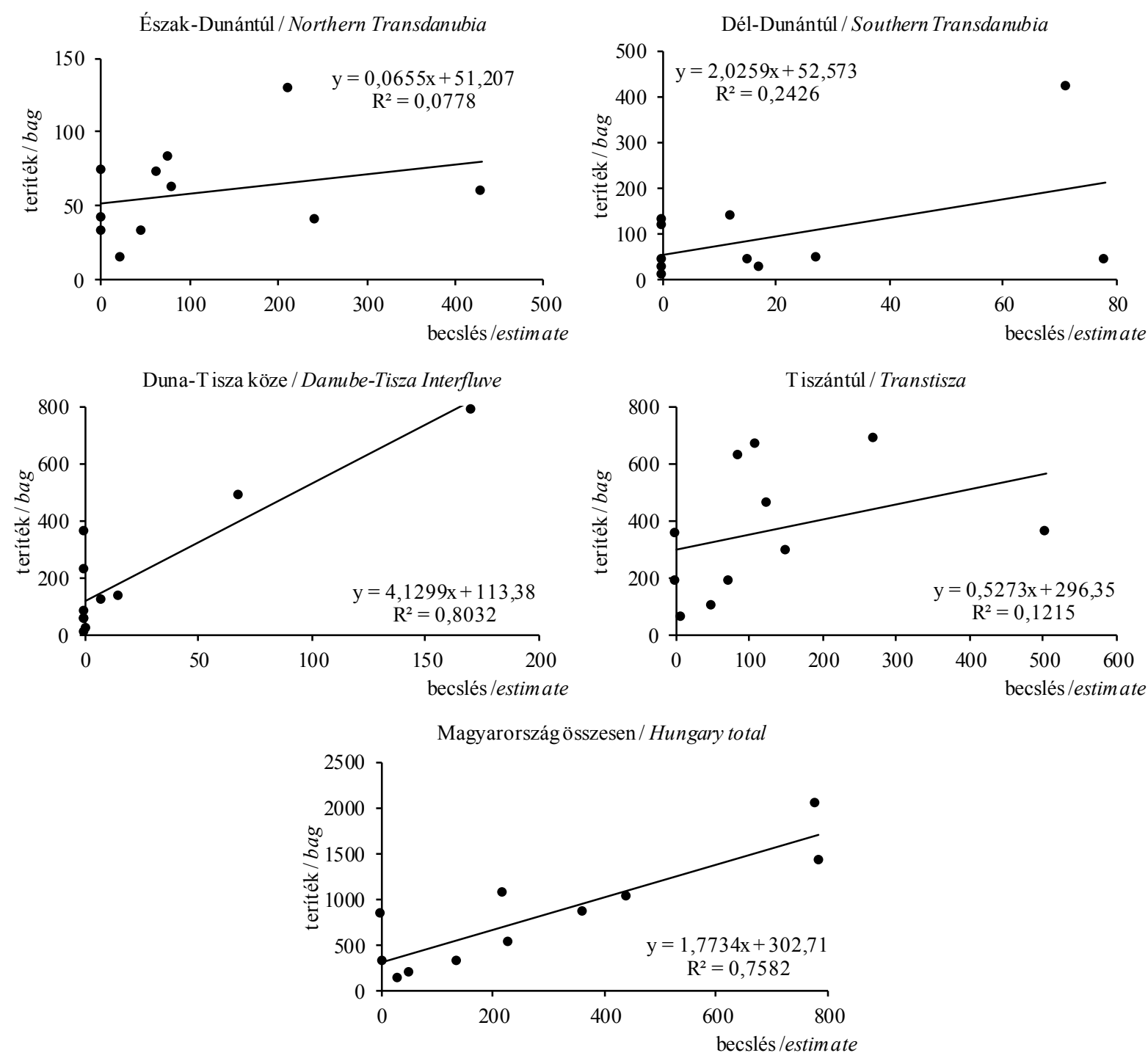

\section{6. ábra: A böjti réce becsült állománynagysága és terítéke közötti összefüggés a vadászati idényben Magyarországon, 1996-2007}

Figure 26: Relation between the estimated population and the hunting bag of Garganey in the hunting season between 1996 and 2007

A BARÁTRÉCE esetében a becslés és a teríték összehasonlító területi diszperziója az alábbi képet mutatja:

$\begin{array}{lcc} & \text { Becslés } & \text { Teríték } \\ \text { Észak-Dunántúl } & 13 \% & 11 \% \\ \text { Dél-Dunántúl } & 33 \% & 5 \% \\ \text { Duna-Tisza köze } & 10 \% & 8 \% \\ \text { Észak-Magyarország } & 0 \% & 6 \% \\ \text { Tiszántúl } & 44 \% & 70 \%\end{array}$

Az adatokból két egyenetlenség mutatható ki, egyrészt a barátréce dél-dunántúli alulhasznosítása, másrészt a tiszántúli megjelenési arányához képest kialakult magas lelövési aránya, ami persze nem jelent feltétlen túlhasznosítást, amit a regressziós kapcsolat is megerősít.

A becslés és teríték értékelhető (4 régióra vonatkoztatott) regressziós kapcsolatai szerint sehol nincs szignifikáns összefüggés az állomány és a teríték nagyság-változása ( 27. ábra; 20. és 23c. melléklet) . A laza kapcsolatok ugyanakkor azt is mutatják, hogy a 
mintaterületek egyedszám növekedésével párhuzamos terítékalakulás inkább csökkenő tendenciát mutat, azaz az állománynövekedés a teríték csökkenéséhez vezet. A DélDunántúlon alacsony szintü összefüggés $\left(\mathrm{R}^{2}=0,1043\right)$ volt kimutatható, ugyanakkor a kapcsolat tendenciája kedvező képet mutat, azaz egy növekedésében korlátozott kapcsolati függvénygörbét.
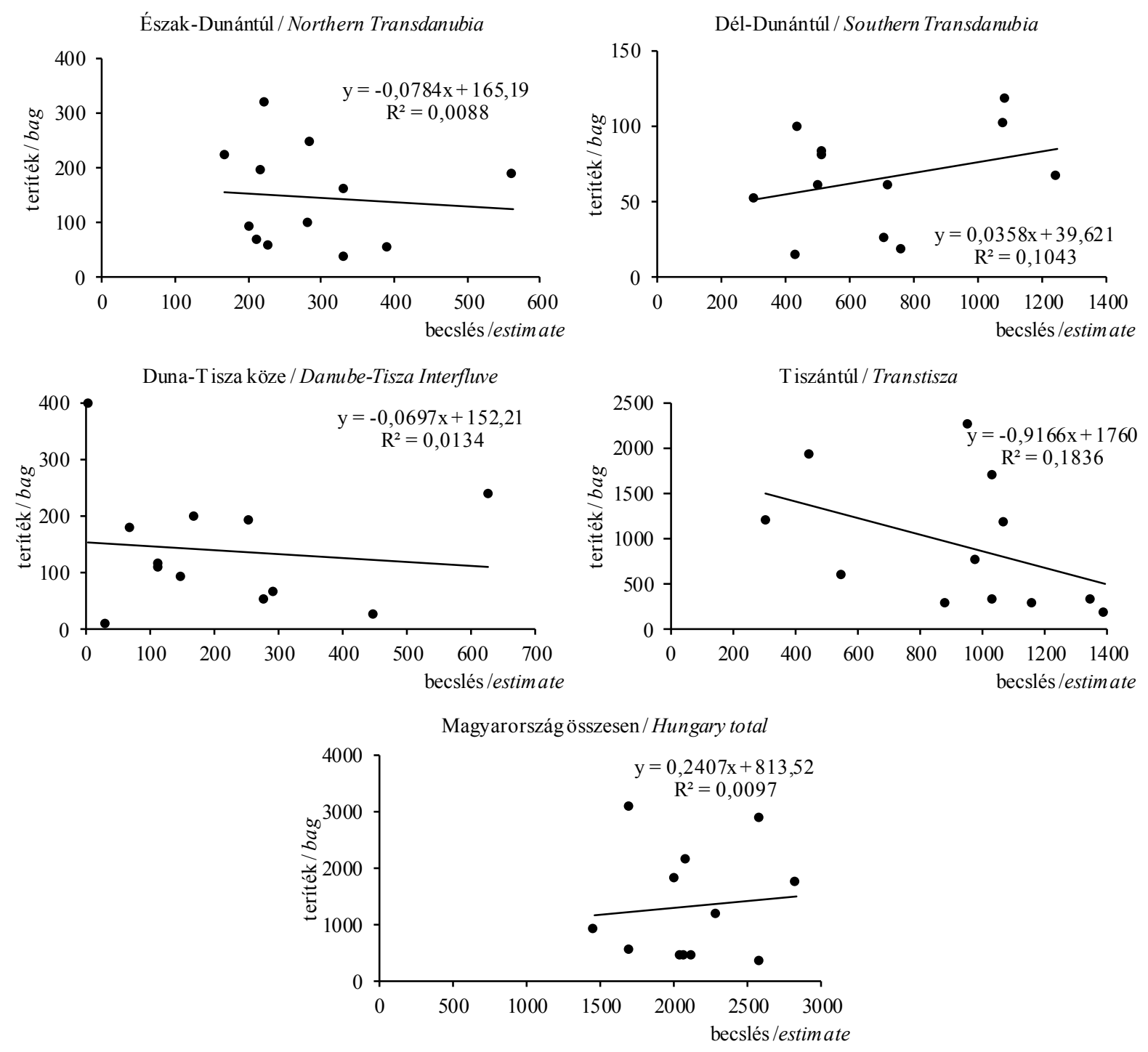

27. ábra: A barátréce becsült állománynagysága és terítéke közötti összefüggés a vadászati idényben Magyarországon, 1996-2008

Figure 27: Relation between the estimated population and the hunting bag of Common Pochard in the hunting season between 1996 and 2008

A KERCERÉCE esetében a becslés és a teríték összehasonlító területi diszperziója az alábbi képet mutatja:

$\begin{array}{lcc} & \text { Becslés } & \text { Teríték } \\ \text { Észak-Dunántúl } & 62 \% & 5 \% \\ \text { Dél-Dunántúl } & 26 \% & 5 \% \\ \text { Duna-Tisza köze } & 9 \% & 13 \% \\ \text { Észak-Magyarország } & 0 \% & 4 \% \\ \text { Tiszántúl } & 3 \% & 73 \%\end{array}$


Az adatokból újfent két egyenetlenség mutatható ki, egyrészt a kerceréce dunántúli alulhasznosítása, másrészt a tiszántúli megjelenési arányához képest kialakult magas lelövési aránya. Tudva, hogy az országos teríték a vizsgált időszakban 10-755 pd között alakult, akkor ennek nagy jelentőséget nem kell tulajdonítani.
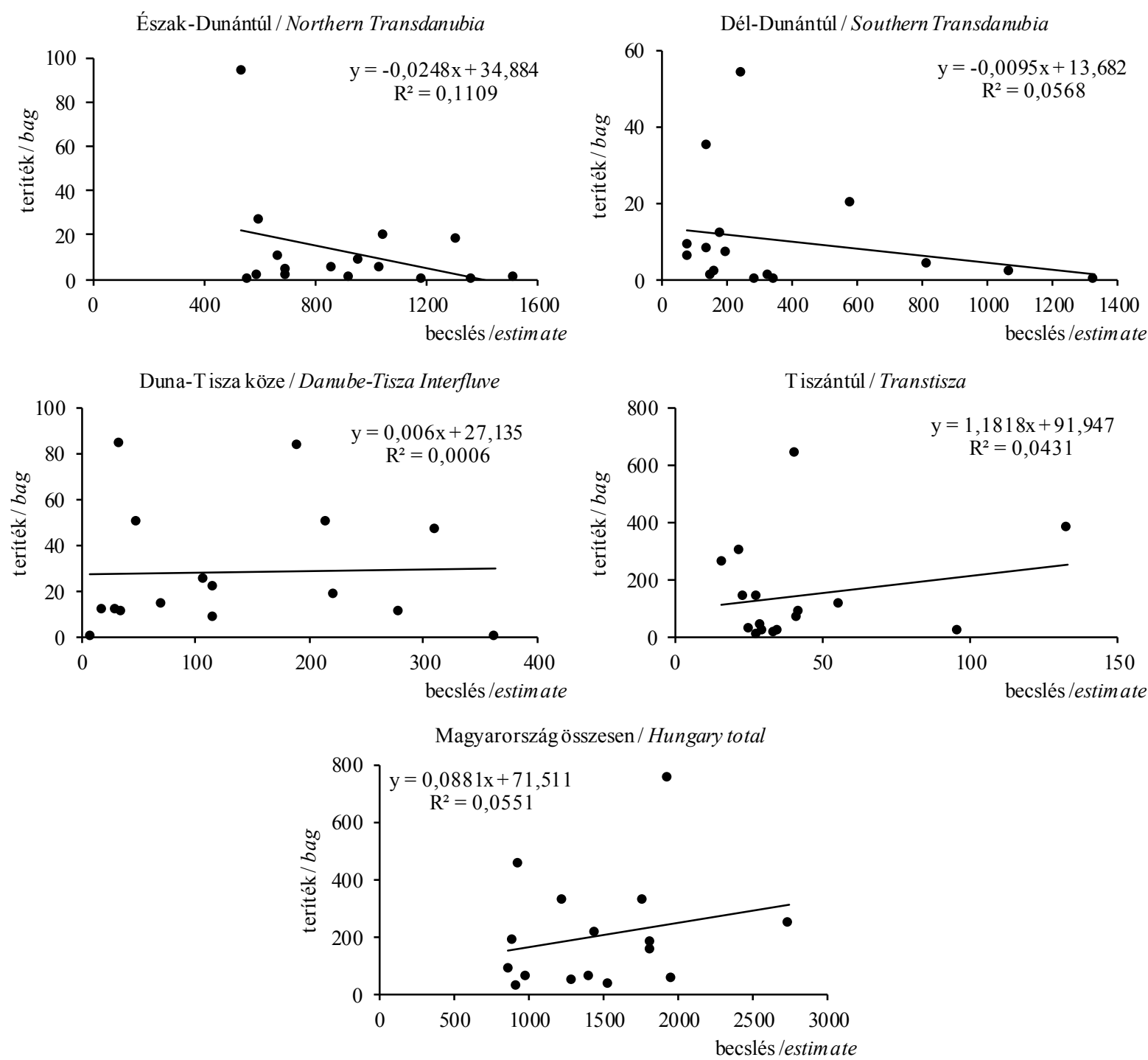

\section{8. ábra: A kerceréce becsült állománynagysága és terítéke közötti összefüggés a} vadászati idényben Magyarországon, 1996-2012

Figure 28: Relation between the estimated population and the hunting bag of Common Goldeneye in the hunting season between 1996 and 2012

A becslés és teríték értékelhető ( 4 régióra vonatkoztatott) regressziós kapcsolatai szerint igen gyenge $(\mathrm{r}=0,1109)$ összefüggés mutatkozott az állomány és a teríték nagyság-változása $(\mathbf{2 8}$. ábra; 21. és 23c. melléklet) között az Észak-Dunántúlon. A gyenge kapcsolat ugyanakkor együtt járt azzal, hogy a mintaterületek egyedszám növekedésével párhuzamos terítékalakulás inkább csökkenő tendenciát mutatott, azaz az állománynövekedés a teríték csökkenéséhez vezetett. Ennek voltunk tanúi a Dél-Dunántúlon is. Nem volt szignifikáns összefüggés a többi régióban és országosan sem. Az alföldi területeken, ahol bizonytalanabb a megjelenése, mégis relatíve magas a hasznosítása, a kapcsolat típusa inkább a stagnálásra, vagy növekedésre (Tiszántúl) utal, amit a faj halastavi koncentrált előfordulásával és elérhetőségével magyarázhatunk 
A SZÁRCSA esetében a becslés és a teríték összehasonlító területi diszperziója az alábbi képet mutatja:

$\begin{array}{lcc} & \text { Becslés } & \text { Teríték } \\ \text { Észak-Dunántúl } & 19 \% & 21 \% \\ \text { Dél-Dunántúl } & 29 \% & 11 \% \\ \text { Duna-Tisza köze } & 1 \% & 15 \% \\ \text { Észak-Magyarország } & 0 \% & 5 \% \\ \text { Tiszántúl } & 51 \% & 48 \%\end{array}$

Az adatokból egyrészt a szárcsa dél-dunántúli alulhasznosítása, másrészt az észak-dunántúli és különösen a Duna-Tisza közi képviseletéhez képest kialakult magas lelövési aránya tünik ki. E területeken azonban csak ott kell veszélytől tartani, ahol a becslés : teríték regressziós függvény kapcsolatai is erőteljes növekedést mutatnak. Ilyen helyzet a Duna-Tisza közén fennáll.
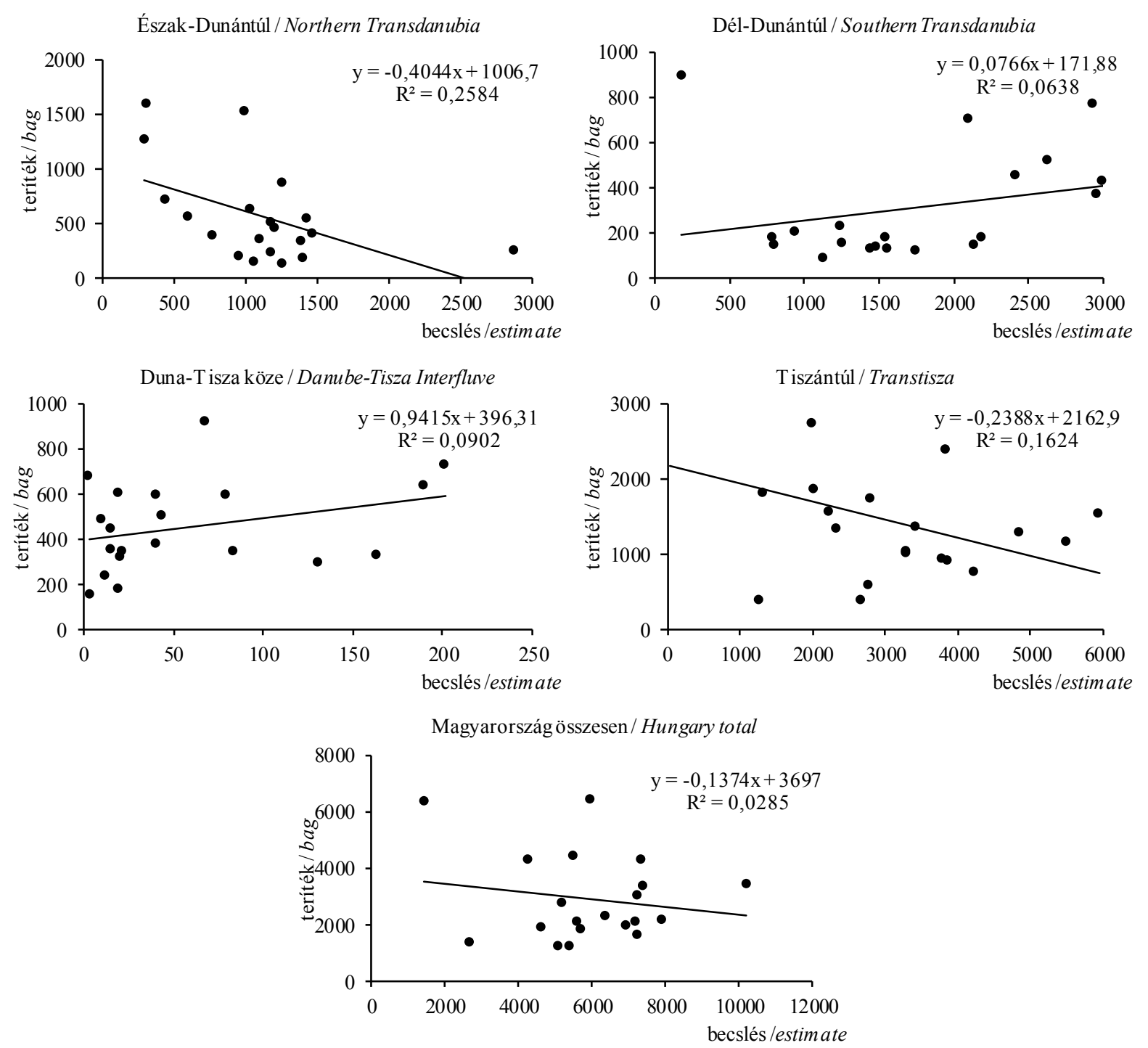

29. ábra: A szárcsa becsült állománynagysága és terítéke közötti összefüggés a vadászati idényben Magyarországon, 1996-2016

Figure 29: Relation between the estimated population and the hunting bag of Eurasian Coot in the hunting season between 1996 and 2016 
A becslés és teríték értékelhető (4 régióra vonatkoztatott) regressziós kapcsolatai szerint nagyon gyenge $\left(\mathrm{R}^{2}=0,2584\right.$ és $\left.\mathrm{R}^{2}=0,1624\right)$ összefüggés mutatkozott az állomány és a teríték nagyság-változása (29. ábra; 22. és 23c. melléklet) között az Észak-Dunántúlon és a Tiszántúlon. A laza kapcsolat dacára e fajnál is az látszik, hogy a mintaterületek észlelt egyedszám növekedéssel párhuzamos terítékalakulás csökkenő tendenciát mutat, azaz az állománynövekedés a teríték csökkenéséhez vezetett. Ugyanez volt észlelhető országos szinten, bár ott a kapcsolat nem volt szignifikáns $\left(\mathrm{R}^{2}=0,0285\right)$. Nem volt szignifikáns a kapcsolat a Dél-Dunántúlon $\left(\mathrm{R}^{2=} 0,0638\right)$ és a Duna-Tisza közén $\left(\mathrm{R}^{2}=0,0902\right)$, ahol a kapcsolat típusa viszont inkább enyhe növekedést mutatott.

Mindezek alapján kijelenthetö, hogy - összhangban a Bonni Konvenció és az AEWA ajánlásaival - Magyarországon a récék és a szárcsa védelme és vadászata a bölcs hasznositás szellemében történt és történik. Ennek a fenntartható, ső́t fenntartó hozzáállásnak a következménye és eredménye volt a veszélyesen csökkenö hazai és európai státusú és állománytrendü fajok vadászatának megszüntetése.

Így vált védetté a böjti réce (Anas querquedula) 2007-töl, a barátréce (Aythya ferina) 2008tól a csörgö réce (Anas crecca) és a kerceréce (Bucephala clangula) 2012-töl.

\subsection{A VÍZIVAD GAZDÁLKODÁS ÉS A TŐKÉS RÉCE TENYÉSZTÉS VISZONYA}

A vízivad vadászat természetes bizonytalansága, ugyanakkor az iránta megmutatkozó fokozódó érdeklődés, nemkülönben a természetvédelmi érdekek egyre határozottabb érvényesülése és érvényesítése következményeként az 1970-es években program fogalmazódott meg a „vadréce” tenyésztés fejlesztésével kapcsolatosan (NAGY \& PUSKÁs, 1978). Ehhez alapot az a kétségtelen tény adott, hogy erre az időszakra kikristályosodott a félvad és az intenzív récenevelés elmélete és gyakorlata (NAGY, 1971). A fejlesztést a tőkés récének a fácánnál is jobb biológiai paramétereire alapozták, amiért is a „vadréce perspektivikus szárnyasvadként jöhet számitásba". Jól érzékelték, hogy az intenzív, zárttéri tenyésztés nagyobb beruházást igényel, ezért vadásztársasági szinten nem valósítható meg, viszont a félvadtenyésztés nem igényel különösebb beruházást. Az intenzív telepeknek a lokális tömegtermelésben és a törzsanyag-ellátásban lehet szerepük. Úgy ítélték meg, hogy a félvadtenyésztés lényegében minden - arra alkalmas - vízfelület tenyésztésbe történő bevonásával országos méretekben is elterjeszthető. Magyarország állóvizeiböl (akkor cca. 90000 ha) mintegy 45000 ha-t (a Dunántúlon 21000 ha-t, a Duna-Tisza közén 15200 ha-t, a Tiszántúlon 8700 ha-t) ítéltek alkalmasnak erre a munkára. Technológiai szempontból nem számoltak a halastavakkal, a víztározók egy részével, a 0,5 hektárnál kisebb és a 20 hektárnál nagyobb vízfelületekkel. A fejlesztés első ütemében (1985-ig) 20000 ha vízfelület tenyésztésbe vonásával számoltak. A kitüzött cél az éves 1 millió példány törzsanyagellátása már akkor biztosított volt. 1984-re már 200000 pd kitelepített törzsállományt terveztek, ami biztosította volna a tervezett éves 1 milliós hasznosítást. Mindehhez szükséges lett volna a szakmai elszántság és összefogás, valamint az oktatás és továbbképzés kiterjesztése (NAGY \& PUSKÁS, 1978).

A tőkés réce zárttéri törzsállománya az 1980-as években 15 000-17 000 pd között állandósult (30. ábra), a röptetett réce terítéknagysága - amely kibocsátások mintegy $2 / 3$ részét jelentette - 40000 pd-ról mintegy 140000 pld-ra növekedett (31. ábra).

Az adatokból kitünik, hogy az 1978-ban megfogalmazott célokat 10 év alatt még csak megközelíteni sem sikerült, ami természetesen a kívánt szakmai-társadalmi összefogás hiányára, továbbá a rendszerváltás előtti romló gazdasági helyzet vadásztársaságokat leginkább sújtó körülményeire volt visszavezethető. Éppen ezért az 1980-as évek végén 
NAGY (1989) már az intenzív tenyésztés nagyobb hatékonyságú és a tőkeerős nagyobb vadgazdálkodók számára elérhető technológiáját ajánlotta elsősorban, azzal, hogy a többi gazdálkodó számára - amennyiben tudja működtetni - a félvadtenyésztés a követhető eljárás.

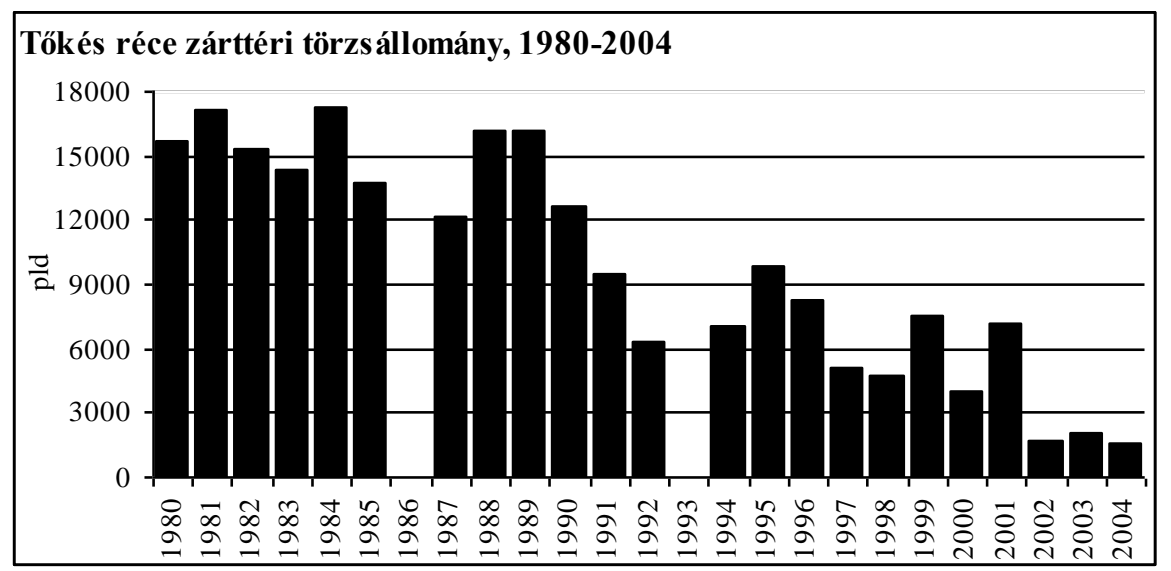

30. ábra: A tőkés réce zárttéri törzsállományának alakulása Magyarországon 1980-2004 között a vadászati statisztikákban (OVA alapján)

Figure 30: Dynamics of breeding stock of Mallard in Hungary in the hunting statistics between 1980 and 2004 (after Hungarian Game Management Data Base)

A rendszerváltoztatás után mind a törzsállomány, mind a kibocsátott mennyiség, mind a röptetett réce teríték jelentősen csökkent, aminek részben gazdálkodási okai (tőkeszegénység), részben a vajúdó vadászati törvény halogatásából fakadó „létbizonytalanság” volt az oka. A törvény életbelépése után (1995) sem volt érzékelhető a vadgazdálkodók által fenntartott telepek törzsállomány növekedése, sőt az új évezred első évtizedének közepére gyakorlatilag megszünt a vadgazdálkodók tőkés réce tenyésztése (30. ábra), a kibocsátott illetve röptetett réce kizárólagosan a vállalkozói szférából származott és származik, amelynek mértéke már nem szerepelhet a vadászati statisztikákban. Ugyanakkor a röptetett réce terítéke (31. ábra) a stabilizáló 1995 után az ezredfordulóig ismét jelentősen nőtt, és elérte az 1980-as évek csúcsértékét. Ismételjük, ez csak úgy volt lehetséges, hogy a tenyésztés súlypontja - a vadászati statisztikákban nem szereplő - a magánszférára helyeződött át, sem jelentős állóeszköz beruházásra, sem költséges törzsállománytartásra, sem tojatásra, sem elő- és közép-nevelésre nem kell a máig tőkehiányban szenvedő vadgazdálkodóknak forrásokat mozgósítaniuk.

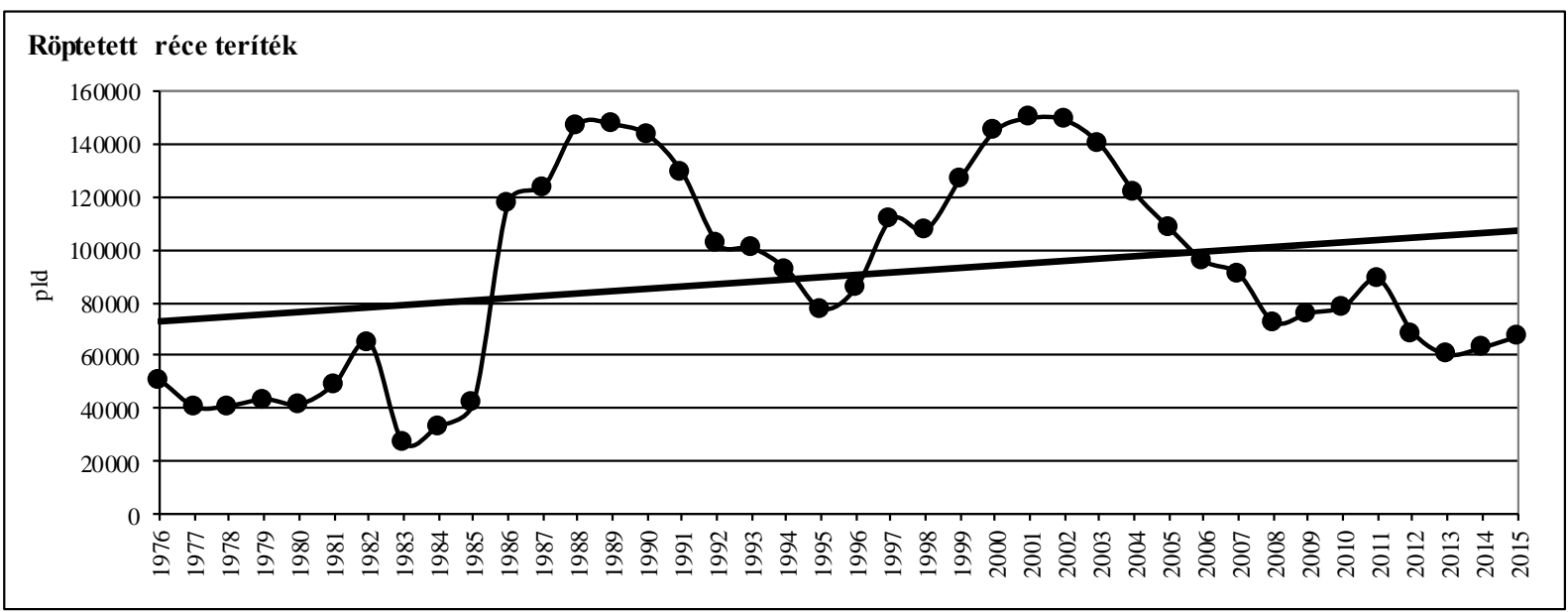

31. ábra: A röptetett réce teríték alakulása Magyarországon 1976-2015

Figure 31: Bag of released hand reared Mallard in Hungary 1976-2015 

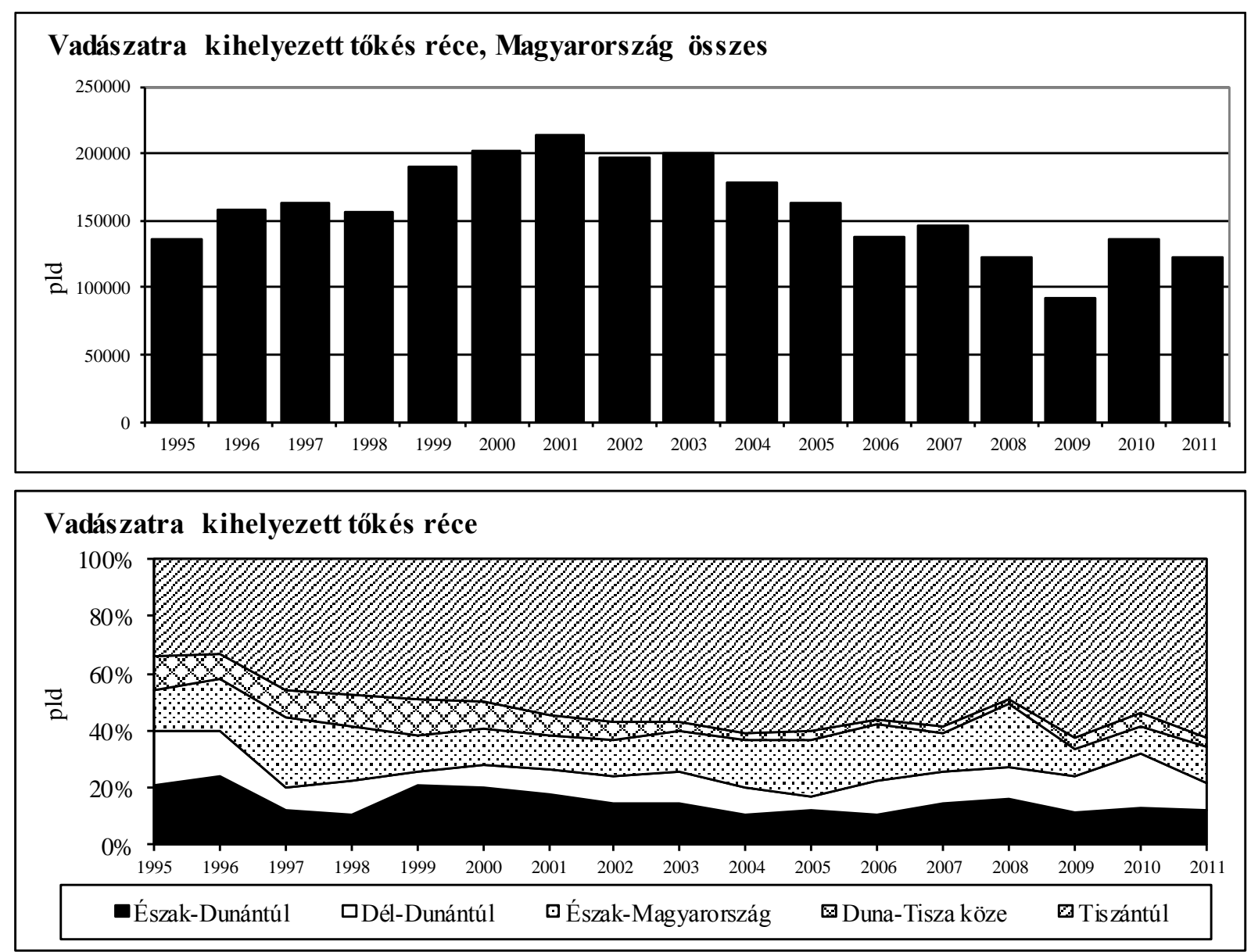

32. ábra: A vadászatra kihelyezett tőkés réce mennyisége és területi megoszlása, 1994-2011 Figure 32: Quantity and regional dispersion of released hand reared Mallard for shooting in Hungary 1994-2011

A korrekt statisztikai adatokkal jellemezhető utolsó 20 évben (1995-2015), a vadászatra kihelyezett tőkés récék mennyisége (32. ábra; 24. melléklet) 136000 pld-ról (1995) 214000 pld-ra (2001) nőtt, amelyből aztán 150000 pld (70\%) terítékre is került. Az utolsó 3 évben valamelyest csökkent a tenyésztési és kibocsátási kedv, 2004-ben már csak 178000 pld-t bocsátottak ki (-36.000 pld) és 121000 pld-t lőttek (68\%). Ez a kibocsátási kedv 2011-ig tovább csökkent, 2011-ben 123062 pd helyeztek ki és abból 88576 pd vadásztak vissza (72\%) (CSÁNYI, 1999; 2000; 2001; 2002; 2003; 2004; 2005; CsÁNYI et al. 2006; 2007; 2008; 2009; 2010; 2012a; 2012b).

A kibocsátott tőkés récék megoszlása a régiók között lényeges változást mutatott (32. ábra) ezen időszakban (1995 $\rightarrow 2015)$, amennyiben az abszolút értékek általános csökkenése mellett, a relatív értékek nőttek a Tiszántúlon $(31 \rightarrow 63 \%)$ és Észak-Magyarországon $(15 \rightarrow 17 \rightarrow 22 \%)$, másutt azonban mindenütt csökkenést lehetett kimutatni (Észak-Dunántúl: $21 \rightarrow 12 \%$; Dél-Dunántúl: $19 \rightarrow 10 \%$; Duna-Tisza köze: $12 \rightarrow 3 \%$ ). Történt mindez annak ellenére, hogy - mint korábban láttuk - a Dunántúlon és a Duna-Tisza közén a tőkés réce tenyésztésére többszörösen nagyobb területek állnak rendelkezésre (a Dunántúlon 21000 ha, a Duna-Tisza közén 15200 ha), mint a Tiszántúlon (8700 ha) (NAGY \& PUSKÁs, 1978). Úgy tünik, hogy a tőkés réce tenyésztése és kibocsátása változatlanul csak a vadgazdálkodók anyagi helyzetének a függvénye, s nem az ökológiai-tenyésztési potenciál által megszabott, korlátozott tevékenység. 
Összegzésként megállapíthatjuk, hogy a természetes élőhelyek kímélete és a szabadterületi vízivad állomány-gazdálkodás mellett és azzal összhangban - figyelembe véve a piaci igényeket és a gazdálkodói lehetőségeket -, támogatható a félvad és elfogadható az intenzív tökés réce nevelés fenntartása. A genetikailag tiszta, betegségektöl mentes kibocsátott (pl. röptetett) tökés réce vadászata - gazdaságossága mellett - csökkenti a vadászati nyomást a vad populációkban, s csökkenti a természetes élöhelyeken a zavarásból eredö veszteségeket. A vadászat módját és mértékét azonban összhangba kell hozni a társadalom állatvédelem szempontjából egyre érzékenyebb értékrendjével.

\subsection{A VÍZIVAD VADÁSZAT SZABÁLYOZÁSÁNAK ÉRTÉKELÉSE}

Az ezredforduló tájékán kidolgozott MAGYAR VÍZIVAD INFORMÁciós RENDSZER (FARAGÓ, 1998c) müködtetésének célja a vad- és természetvédelmi, valamint vadászativadgazdálkodási politika megfogalmazása, folyamatos aktualizálása. Ebben a fejezetben kísérletet teszünk arra, hogy értékeljük az ott bemutatott - az AEWA ajánlásai szellemében megvalósuló - vadvédelmi szempontokat és védelmi gyakorlatot. Ismételve, ezek a kérdések a következők:

(1) A vadászható fajok köre

(2) A vadászati idények

(3) A vadászati módszerek

(4) Vadászati statisztika, terítékadatok

\subsubsection{A vadászható fajok köre}

A vadászható fajok köre mindenkor összefüggött azok gyakoriságával - természetesen az élelmezés célú felhasználhatóságuk mellett. A vízivad fajok közül is a vadászható fajoknak kellene a leggyakoribbaknak lenniük. Az 1996/1997 - 2015/2016 szezonokban (20 szezon) idényenként 39-48 fajt figyeltünk meg. A fajok havonkénti, mennyiségi sorrendbe állításával (2. táblázat), majd a vadászható fajok évenkénti és havonkénti rangsorrend átlagait képezve megállapíthatjuk, hogy a mindenkor hatályos jogszabályok valóban a leggyakoribb vízivad fajok elejtését teszik-e lehetővé. Ideális esetben a 20 év során vadászható 5-9 vízivad fajnak kellene az első 5-9 helyen szerepelnie. Természetesen azzal is tisztában vagyunk, hogy a vizsgálati időszakban vadászható fajoknak egy része - ANSFAB, ANSALB, BUCCLA - csak késő ősszel, vagy télen van nagyobb számban nálunk, az ANAQUE viszont éppen erre az időszakra keres magának afrikai telelőterületeket. A harmadik csoportba soroljuk a (saját állományból származó, vagy északról érkező) áttelelőket: ANAPLA, ANACRE, FULATR. A létszámot ezen felül, az egyes hónapokban a vonulás dinamika is motiválja.

$\mathrm{Az}$ átlagos rangsorrend alapján a leggyakoribb vízivad fajok a vadászidényben az alábbiak:

$\begin{array}{ll}\text { ANAPLA (szept. - jan.) } & 1,1-2,0 \text { átlagos rangsor hely } \\ \text { ANSALB (okt. }- \text { jan.) } & 1,4-6,4 \\ \text { ANSANS (okt. }- \text { dec.) } & 2,8-3,8 \\ \text { FULATR (szept. }- \text { jan.) } & 2,8-8,6 \\ \text { ANACRE (szept. }- \text { jan.) } & 3,7-8,2 \\ \text { ANSFAB (okt. }- \text { jan.) } & 4,2-10,0 \\ \text { BUCCLA (okt. - jan.) } & 6,2-31,7 \\ \text { AYTFER (okt. }- \text { jan.) } & 9,5-11,3 \\ \text { ANAQUE (szept. }- \text { jan.) } & 18,2-37,8\end{array}$


2. táblázat: A vadászható vízivad fajok szezononkénti és havi rangsorai, és azok átlagai Table 2: Seasonal ranks and mean of ranks of huntable waterfowl species in each months

\begin{tabular}{|c|c|c|c|c|c|}
\hline ANS FAB & Szept. & Okt. & Nov. & Dec. & Jan. \\
\hline $1996 / 1997$ & - & 2 & 3 & 2 & 1 \\
\hline $1997 / 1998$ & 14 & 2 & 2 & 1 & 1 \\
\hline $1998 / 1999$ & 7 & 2 & 3 & 1 & 2 \\
\hline $1999 / 2000$ & 16 & 4 & 3 & 2 & 2 \\
\hline $2000 / 2001$ & 8 & 5 & 3 & 3 & 3 \\
\hline $2001 / 2002$ & 12 & 3 & 3 & 2 & 2 \\
\hline $2002 / 2003$ & 28 & 4 & 4 & 3 & 1 \\
\hline $2003 / 2004$ & 12 & 7 & 4 & 3 & 2 \\
\hline $2004 / 2005$ & 15 & 6 & 4 & 3 & 3 \\
\hline $2005 / 2006$ & 32 & 6 & 6 & 3 & 2 \\
\hline $2006 / 2007$ & 32 & 6 & 6 & 3 & 2 \\
\hline $2007 / 2008$ & 31 & 13 & 5 & 3 & 4 \\
\hline $2008 / 2009$ & 33 & 14 & 6 & 4 & 4 \\
\hline $2009 / 2010$ & 31 & 16 & 7 & 4 & 4 \\
\hline $2010 / 2011$ & 30 & 14 & 8 & 5 & 4 \\
\hline $2011 / 2012$ & 40 & 14 & 9 & 5 & 4 \\
\hline $2012 / 2013$ & 37 & 20 & 9 & 5 & 4 \\
\hline $2013 / 2014$ & 23 & 19 & 8 & 5 & 6 \\
\hline $2014 / 2015$ & 27 & 19 & 12 & 13 & 8 \\
\hline $2015 / 2016$ & 39 & 24 & 9 & 14 & 8 \\
\hline Átlag & $\mathbf{2 4 , 6}$ & $\mathbf{1 0 , 0}$ & $\mathbf{5 , 7}$ & $\mathbf{4 , 2}$ & $\mathbf{3 , 4}$ \\
\hline
\end{tabular}

\begin{tabular}{|c|c|c|c|c|c|}
\hline ANS ANS & Szept. & Okt. & Nov. & Dec. & Jan. \\
\hline $1996 / 1997$ & - & 4 & 5 & 4 & 3 \\
\hline $1997 / 1998$ & 3 & 3 & 3 & 4 & 4 \\
\hline $1998 / 1999$ & 4 & 4 & 4 & 4 & 4 \\
\hline $1999 / 2000$ & 2 & 2 & 4 & 4 & 3 \\
\hline $2000 / 2001$ & 2 & 2 & 4 & 4 & 4 \\
\hline $2001 / 2002$ & 4 & 2 & 4 & 4 & 4 \\
\hline $2002 / 2003$ & 3 & 3 & 3 & 4 & 4 \\
\hline $2003 / 2004$ & 2 & 2 & 3 & 4 & 4 \\
\hline $2004 / 2005$ & 2 & 4 & 3 & 4 & 4 \\
\hline $2005 / 2006$ & 4 & 3 & 3 & 4 & 4 \\
\hline $2006 / 2007$ & 4 & 3 & 3 & 4 & 4 \\
\hline $2007 / 2008$ & 2 & 3 & 4 & 4 & 3 \\
\hline $2008 / 2009$ & 2 & 3 & 4 & 3 & 3 \\
\hline $2009 / 2010$ & 2 & 3 & 3 & 3 & 3 \\
\hline $2010 / 2011$ & 2 & 3 & 2 & 3 & 3 \\
\hline $2011 / 2012$ & 2 & 2 & 4 & 4 & 3 \\
\hline $2012 / 2013$ & 1 & 1 & 4 & 3 & 3 \\
\hline $2013 / 2014$ & 2 & 3 & 4 & 3 & 3 \\
\hline $2014 / 2015$ & 2 & 3 & 4 & 4 & 3 \\
\hline $2015 / 2016$ & 2 & 3 & 4 & 4 & 3 \\
\hline Átlag & $\mathbf{2 , 5}$ & $\mathbf{2 , 8}$ & $\mathbf{3 , 6}$ & $\mathbf{3 , 8}$ & $\mathbf{3 , 5}$ \\
\hline
\end{tabular}

\begin{tabular}{|c|c|c|c|c|c|}
\hline ANS ALB & Szept. & Okt. & Nov. & Dec. & Jan. \\
\hline $1996 / 1997$ & - & 7 & 2 & 3 & 4 \\
\hline $1997 / 1998$ & 26 & 10 & 4 & 3 & 3 \\
\hline $1998 / 1999$ & 17 & 7 & 2 & 3 & 3 \\
\hline $1999 / 2000$ & 19 & 7 & 1 & 3 & 4 \\
\hline $2000 / 2001$ & 19 & 3 & 1 & 2 & 2 \\
\hline $2001 / 2002$ & 27 & 7 & 2 & 3 & 3 \\
\hline $2002 / 2003$ & 22 & 5 & 2 & 2 & 3 \\
\hline $2003 / 2004$ & 19 & 6 & 1 & 1 & 1 \\
\hline $2004 / 2005$ & 26 & 10 & 2 & 1 & 2 \\
\hline $2005 / 2006$ & 33 & 9 & 1 & 1 & 1 \\
\hline $2006 / 2007$ & 33 & 9 & 1 & 1 & 1 \\
\hline $2007 / 2008$ & 32 & 5 & 1 & 1 & 1 \\
\hline $2008 / 2009$ & 27 & 8 & 1 & 1 & 1 \\
\hline $2009 / 2010$ & 32 & 5 & 1 & 1 & 1 \\
\hline $2010 / 2011$ & 27 & 5 & 1 & 1 & 1 \\
\hline $2011 / 2012$ & 27 & 6 & 1 & 1 & 1 \\
\hline $2012 / 2013$ & 14 & 4 & 1 & 1 & 1 \\
\hline $2013 / 2014$ & 11 & 4 & 1 & 1 & 1 \\
\hline $2014 / 2015$ & 18 & 5 & 1 & 1 & 1 \\
\hline $2015 / 2016$ & 6 & 6 & 1 & 1 & 1 \\
\hline Átlag & $\mathbf{2 2 , 9}$ & $\mathbf{6 , 4}$ & $\mathbf{1 , 4}$ & $\mathbf{1 , 6}$ & $\mathbf{1 , 8}$ \\
\hline
\end{tabular}

\begin{tabular}{|c|c|c|c|c|c|}
\hline ANA PLA & Szept. & Okt. & Nov. & Dec. & Jan. \\
\hline $1996 / 1997$ & - & 1 & 1 & 1 & 2 \\
\hline $1997 / 1998$ & 1 & 1 & 1 & 2 & 2 \\
\hline $1998 / 1999$ & 1 & 1 & 1 & 2 & 1 \\
\hline $1999 / 2000$ & 1 & 1 & 2 & 1 & 1 \\
\hline $2000 / 2001$ & 1 & 1 & 2 & 1 & 1 \\
\hline $2001 / 2002$ & 1 & 1 & 1 & 1 & 1 \\
\hline $2002 / 2003$ & 1 & 1 & 1 & 1 & 2 \\
\hline $2003 / 2004$ & 1 & 1 & 2 & 2 & 3 \\
\hline $2004 / 2005$ & 1 & 1 & 1 & 2 & 1 \\
\hline $2005 / 2006$ & 1 & 1 & 2 & 2 & 3 \\
\hline $2006 / 2007$ & 1 & 1 & 2 & 2 & 3 \\
\hline $2007 / 2008$ & 1 & 2 & 2 & 2 & 2 \\
\hline $2008 / 2009$ & 1 & 2 & 3 & 2 & 2 \\
\hline $2009 / 2010$ & 1 & 1 & 2 & 2 & 2 \\
\hline $2010 / 2011$ & 1 & 2 & 3 & 2 & 2 \\
\hline $2011 / 2012$ & 1 & 3 & 2 & 2 & 2 \\
\hline $2012 / 2013$ & 2 & 2 & 3 & 2 & 2 \\
\hline $2013 / 2014$ & 1 & 2 & 2 & 2 & 2 \\
\hline $2014 / 2015$ & 1 & 2 & 3 & 2 & 2 \\
\hline $2015 / 2016$ & 1 & 2 & 3 & 2 & 2 \\
\hline Átlag & $\mathbf{1 , 1}$ & $\mathbf{1 , 5}$ & $\mathbf{2 , 0}$ & $\mathbf{1 , 8}$ & $\mathbf{1 , 9}$ \\
\hline
\end{tabular}


2. táblázat (folyt.): A vadászható vízivad fajok szezononkénti és havi rangsorai, és azok átlagai

Table 2 (cont.): Seasonal ranks and mean of ranks of huntable waterfowl species in each month

\begin{tabular}{|c|c|c|c|c|c|}
\hline ANA CRE & Szept. & Okt. & Nov. & Dec. & Jan. \\
\hline $1996 / 1997$ & - & 3 & 4 & 5 & 14 \\
\hline $1997 / 1998$ & 4 & 5 & 5 & 5 & 5 \\
\hline $1998 / 1999$ & 2 & 5 & 5 & 9 & 5 \\
\hline $1999 / 2000$ & 3 & 3 & 5 & 5 & 6 \\
\hline $2000 / 2001$ & 4 & 4 & 5 & 5 & 6 \\
\hline $2001 / 2002$ & 3 & 4 & 5 & 7 & 9 \\
\hline $2002 / 2003$ & 4 & 3 & 5 & 8 & 17 \\
\hline $2003 / 2004$ & 4 & 3 & 5 & 6 & 7 \\
\hline $2004 / 2005$ & 4 & 5 & 5 & 5 & 5 \\
\hline $2005 / 2006$ & 3 & 4 & 5 & 5 & 6 \\
\hline $2006 / 2007$ & 3 & 4 & 5 & 5 & 6 \\
\hline $2007 / 2008$ & 4 & 4 & 6 & 9 & 10 \\
\hline $2008 / 2009$ & 4 & 4 & 5 & 6 & 12 \\
\hline $2009 / 2010$ & 4 & 4 & 6 & 6 & 7 \\
\hline $2010 / 2011$ & 4 & 4 & 4 & 6 & 9 \\
\hline $2011 / 2012$ & 4 & 4 & 5 & 6 & 7 \\
\hline $2012 / 2013$ & 3 & 5 & 5 & 8 & 14 \\
\hline $2013 / 2014$ & 4 & 6 & 5 & 7 & 5 \\
\hline $2014 / 2015$ & 4 & 4 & 5 & 5 & 7 \\
\hline $2015 / 2016$ & 5 & 4 & 5 & 5 & 7 \\
\hline Átlag & $\mathbf{3 , 7}$ & $\mathbf{4 , 1}$ & $\mathbf{5 , 0}$ & $\mathbf{6 , 2}$ & $\mathbf{8 , 2}$ \\
\hline & & & & & \\
\hline
\end{tabular}

\begin{tabular}{|c|c|c|c|c|c|}
\hline ANA QUE & Szept. & Okt. & Nov. & Dec. & Jan. \\
\hline $1996 / 1997$ & - & 20 & 21 & 21 & 32 \\
\hline $1997 / 1998$ & 14 & 22 & 37 & 34 & 34 \\
\hline $1998 / 1999$ & 12 & 22 & 36 & 36 & 35 \\
\hline $1999 / 2000$ & 14 & 25 & 35 & 38 & 36 \\
\hline $2000 / 2001$ & 17 & 20 & 22 & 37 & 36 \\
\hline $2001 / 2002$ & 14 & 19 & 39 & 35 & 34 \\
\hline $2002 / 2003$ & 14 & 20 & 19 & 35 & 35 \\
\hline $2003 / 2004$ & 16 & 18 & 38 & 31 & 36 \\
\hline $2004 / 2005$ & 20 & 26 & 39 & 39 & 37 \\
\hline $2005 / 2006$ & 15 & 22 & 44 & 41 & 27 \\
\hline $2006 / 2007$ & 15 & 22 & 44 & 41 & 27 \\
\hline $2007 / 2008$ & 18 & 24 & 43 & 44 & 25 \\
\hline $2008 / 2009$ & 17 & 25 & 41 & 39 & 42 \\
\hline $2009 / 2010$ & 18 & 24 & 40 & 39 & 40 \\
\hline $2010 / 2011$ & 24 & 31 & 15 & 43 & 37 \\
\hline $2011 / 2012$ & 22 & 32 & 42 & 45 & 39 \\
\hline $2012 / 2013$ & 20 & 24 & 40 & 37 & 39 \\
\hline $2013 / 2014$ & 32 & 47 & 41 & 43 & 43 \\
\hline $2014 / 2015$ & 21 & 44 & 29 & 37 & 41 \\
\hline $2015 / 2016$ & 23 & 30 & 43 & 41 & 39 \\
\hline Átlag & $\mathbf{1 8 , 2}$ & $\mathbf{2 5 , 9}$ & $\mathbf{3 5 , 4}$ & $\mathbf{3 7 , 8}$ & $\mathbf{3 5 , 7}$ \\
\hline
\end{tabular}

\begin{tabular}{|c|c|c|c|c|c|}
\hline AYT FER & Szept. & Okt. & Nov. & Dec. & Jan. \\
\hline $1996 / 1997$ & - & 10 & 9 & 9 & 7 \\
\hline $1997 / 1998$ & 5 & 7 & 10 & 8 & 9 \\
\hline $1998 / 1999$ & 5 & 9 & 9 & 8 & 8 \\
\hline $1999 / 2000$ & 6 & 9 & 11 & 12 & 10 \\
\hline $2000 / 2001$ & 11 & 9 & 10 & 11 & 8 \\
\hline $2001 / 2002$ & 7 & 9 & 9 & 8 & 8 \\
\hline $2002 / 2003$ & 9 & 9 & 9 & 9 & 7 \\
\hline $2003 / 2004$ & 7 & 9 & 10 & 10 & 8 \\
\hline $2004 / 2005$ & 7 & 10 & 10 & 10 & 12 \\
\hline $2005 / 2006$ & 5 & 10 & 10 & 9 & 10 \\
\hline $2006 / 2007$ & 5 & 10 & 10 & 9 & 10 \\
\hline $2007 / 2008$ & 5 & 9 & 9 & 10 & 9 \\
\hline $2008 / 2009$ & 5 & 7 & 10 & 9 & 6 \\
\hline $2009 / 2010$ & 5 & 9 & 16 & 9 & 10 \\
\hline $2010 / 2011$ & 5 & 11 & 12 & 11 & 11 \\
\hline $2011 / 2012$ & 6 & 11 & 14 & 12 & 15 \\
\hline $2012 / 2013$ & 9 & 12 & 12 & 14 & 11 \\
\hline $2013 / 2014$ & 7 & 9 & 17 & 16 & 10 \\
\hline $2014 / 2015$ & 6 & 10 & 13 & 12 & 9 \\
\hline $2015 / 2016$ & 9 & 11 & 15 & 12 & 14 \\
\hline Átlag & $\mathbf{6 , 5}$ & $\mathbf{9 , 5}$ & $\mathbf{1 1 , 3}$ & $\mathbf{1 0 , 4}$ & $\mathbf{9 , 6}$ \\
\hline
\end{tabular}

\begin{tabular}{|c|c|c|c|c|c|}
\hline BUC CLA & Szept. & Okt. & Nov. & Dec. & Jan. \\
\hline $1996 / 1997$ & - & 35 & 17 & 11 & 5 \\
\hline $1997 / 1998$ & 36 & 37 & 14 & 7 & 7 \\
\hline $1998 / 1999$ & 25 & 38 & 15 & 7 & 6 \\
\hline $1999 / 2000$ & 38 & 28 & 17 & 6 & 5 \\
\hline $2000 / 2001$ & 26 & 14 & 13 & 9 & 5 \\
\hline $2001 / 2002$ & 37 & 37 & 13 & 5 & 5 \\
\hline $2002 / 2003$ & 38 & 37 & 14 & 7 & 5 \\
\hline $2003 / 2004$ & 23 & 22 & 18 & 7 & 5 \\
\hline $2004 / 2005$ & 39 & 30 & 20 & 6 & 8 \\
\hline $2005 / 2006$ & 42 & 25 & 18 & 13 & 8 \\
\hline $2006 / 2007$ & 42 & 25 & 18 & 13 & 8 \\
\hline $2007 / 2008$ & 41 & 28 & 17 & 6 & 5 \\
\hline $2008 / 2009$ & 42 & 30 & 17 & 10 & 5 \\
\hline $2009 / 2010$ & 41 & 25 & 17 & 8 & 5 \\
\hline $2010 / 2011$ & 49 & 33 & 20 & 8 & 6 \\
\hline $2011 / 2012$ & 50 & 28 & 19 & 10 & 8 \\
\hline $2012 / 2013$ & 46 & 45 & 17 & 7 & 9 \\
\hline $2013 / 2014$ & 52 & 51 & 15 & 6 & 8 \\
\hline $2014 / 2015$ & 48 & 29 & 20 & 8 & 6 \\
\hline $2015 / 2016$ & 48 & 36 & 19 & 10 & 5 \\
\hline Átlag & $\mathbf{4 0 , 2}$ & $\mathbf{3 1 , 7}$ & $\mathbf{1 6 , 9}$ & $\mathbf{8 , 2}$ & $\mathbf{6 , 2}$ \\
\hline
\end{tabular}


2. táblázat (folyt.): A vadászható vízivad fajok szezononkénti és havi rangsorai, és azok átlagai

Table 2 (cont.): Seasonal ranks and mean of ranks of huntable waterfowl species in each months

\begin{tabular}{|c|c|c|c|c|c|}
\hline FUL ATR & Szept. & Okt. & Nov. & Dec. & Jan. \\
\hline $1996 / 1997$ & - & 5 & 6 & 6 & 9 \\
\hline $1997 / 1998$ & 2 & 4 & 6 & 10 & 8 \\
\hline $1998 / 1999$ & 3 & 3 & 6 & 5 & 7 \\
\hline $1999 / 2000$ & 4 & 5 & 9 & 8 & 7 \\
\hline $2000 / 2001$ & 3 & 6 & 8 & 7 & 7 \\
\hline $2001 / 2002$ & 2 & 5 & 8 & 10 & 10 \\
\hline $2002 / 2003$ & 2 & 7 & 8 & 5 & 9 \\
\hline $2003 / 2004$ & 3 & 8 & 8 & 8 & 10 \\
\hline $2004 / 2005$ & 3 & 3 & 7 & 9 & 10 \\
\hline $2005 / 2006$ & 2 & 5 & 7 & 7 & 9 \\
\hline $2006 / 2007$ & 2 & 5 & 7 & 7 & 9 \\
\hline $2007 / 2008$ & 3 & 6 & 7 & 8 & 8 \\
\hline $2008 / 2009$ & 3 & 5 & 7 & 7 & 7 \\
\hline $2009 / 2010$ & 3 & 6 & 4 & 7 & 8 \\
\hline $2010 / 2011$ & 3 & 7 & 7 & 7 & 10 \\
\hline $2011 / 2012$ & 3 & 5 & 8 & 9 & 9 \\
\hline $2012 / 2013$ & 4 & 7 & 7 & 9 & 8 \\
\hline $2013 / 2014$ & 3 & 5 & 7 & 10 & 13 \\
\hline $2014 / 2015$ & 3 & 6 & 6 & 7 & 5 \\
\hline $2015 / 2016$ & 3 & 5 & 6 & 7 & 9 \\
\hline Átlag & $\mathbf{2 , 8}$ & $\mathbf{5 , 4}$ & $\mathbf{7 , 0}$ & $\mathbf{7 , 7}$ & $\mathbf{8 , 6}$ \\
\hline & & & & & \\
\hline
\end{tabular}

A lista alapján elmondható, hogy tulajdonképpen két libafaj (ANSALB, ANSANS), a szárcsa (FULATR), a tökés réce (ANAPLA) és a csörgöréce (ANACRE) rangsorrend-átlagai maradéktalanul kielégítik az ideális elképzelést. A vetési lúd, amely fenti feltételeket teljesítette a vizsgálatba vont időszak első felében, állománycsökkenésével csak a novemberjanuár időszakban került az élmezőnybe $(3,4-5,7)$, de rangsorának előkelő helyét a korábbi időszak pozíciói miatt tarthatta meg. A kerceréce - BUCCLA - egyedei a kívánt rangsorrend tartományt csak decemberben és januárban érik el. Így elvileg elégséges lett volna rájuk a december 1.-január 31. közötti vadászidény. A barátréce (AYTFER), amelynek korábbi magas állománynagyságai igazolták a vadászhatóságot, mennyiségi sorrendben összesítésben a nyolcadik helyre szorult, egyetlen hónapban sem volt a leggyakoribb fajok között.

Ugyanez volt a helyzet a böjti récével (ANAQUE), amelynek érdemleges helyezése csak szeptemberben lehetett (12-32. hely, átlagosan 18,2), azt követően nagyon kisszámú, vagy 0 a megfigyelés - hiszen Afrikában telel - ami értelmetlenné tette a korábbi (január 31.ig tartó) vadászidényét. Mára a faj védett, amit a vonuló állomány erősen csökkenő trendje, európai veszélyeztetettsége, és nem utolsó sorban kis hazai állománynagysága indokol. Védelme tehát több oldalról is igazolt és fenntartandó.

Az 5 napjainkban vadászható vízivad faj állományainak ismeretében elmondható, hogy általában a leggyakoribb magyarországi vízivad fajokat érinti a hasznosítás, így ebben a vonatkozásban maradéktalanul megfelel jogi szabályozásunk a nemzetközi elvárásoknak és a bölcs hasznosítás elvének. Ki kell emelnünk azonban a vetési ludat, amelynek utóbbi időben észlelt drámai mértékü állománycsökkenése vadászatának felfüggesztését igényli.

Az értékelés során azonban az is szembetünő, hogy a ranglista elején helyezkednek el nagy gyakoriságú védett fajok is, amely legalábbis kérdésessé teszi az előbb ismertetett és elismert logika teljes körü érvényességét és érvényesülését. Ezek, gyakoriságuk és 
vadászidényen belüli tartamosságuk (hónapok száma) alapján rendre az alábbiak: kárókatona, kanalas réce, fütyülő réce, kontyos réce, szürke gém, búbos vöcsök, kendermagos réce és cigányréce. A nyári lúd az az egyedüli korábban védett faj, amelynek magas rangsorbeli helyezése 2012-ben elvezetett védelmének feloldásához.

A felsorolt fajok közül biztosan nincs vadászati érdeklödés a kárókatonára, a szürke gémre és a búbos vöcsökre. Globálisan veszélyeztetett faj a cigányréce, tehát vadászata szóba sem kerülhet. Tekintsük át a fennmaradó 5 faj helyzetét.

A kanalas réce védelem alatt álló, fészkelő (500-600 pár) fajunk, országos állománydinamikája a vizsgálati időszakban enyhe növekedést mutatott. Európában nem SPEC faj, európai védelmi helyzete stabil (S), szerepel a Berni Egyezmény III. Mellékletében, a Bonni Egyezmény II. Függelékében. Vadászatának kérdése nincs napirenden.

A fütyülö réce 1993-ban került le a vadászható fajok listájáról, akkor is észlelt csökkenő állománydinamikája alapján. A helyzet nem változott, hiszen az elmúlt időszakban is folyamatosan csökkent nálunk megjelent mennyisége. Európában nem SPEC faj, európai védelmi helyzete stabil (S), szerepel a Berni Egyezmény III. Mellékletében, a Bonni Egyezmény II. Függelékében. Ismételt vadászatának kérdése nincs napirenden.

A kendermagos réce ritka (100-200 pár) fészkelő fajunk, állománynagysága szeptemberi-októberi magasabb létszámok mellett - stabil. Európában SPEC 3-as faj, veszélyeztetett (V), szerepel az EU Madárvédelmi Irányelv II. Mellékletében (azaz vadászható a nemzeti törvények szerint), a Berni Egyezmény III. Mellékletében, a Bonni Egyezmény II. Függelékében. Vadászatának kérdése nincs napirenden.

A kontyos réce csak az utóbbi évtizedekben vált biztosan költő fajunkká (80-100 pár), országos állománydinamikája enyhe csökkenést mutat. Európában nem SPEC faj, európai védelmi helyzete stabil (S), szerepel a Berni Egyezmény III. Mellékletében, a Bonni Egyezmény II. Függelékében. Vadászatának kérdése nincs napirenden.

Mindezen természetvédelmi keretszabályok, mennyiségi kritériumok, és hasznosítási szándék ismeretében egyedül a nyári lúd vadászatának bevezetését lehetett minden szempontból megindokolni (FARAGÓ, 2001d; 2005c), ami 2012-ben meg is történt.

A vízivad fajok hatályos jogszabályokon alapuló köre vizsgált időszakban egyedül a nyári lúddal bövült, a böjti réce, a csörgö réce, a barátréce és a kerceréce pedig védett lett, lekerült a vadászható fajok listájáról. Kijelenthetō, hogy a vízivad fajokat érintő magyar vadászati szabályozás megfelel a nemzetközi elvárásoknak és megfelelö módon igazodik nemzetközi egyezményekhez és jogi kötelezettségekhez. Ugyanakkor a vetési lúd elmúlt két évtizedben tapasztalt drámai közép-európai állománycsökkenése indokolja vadászatának átmeneti felfüggesztését.

\subsubsection{A vadászati idények}

A vadászati idényekről az LV. Törvény az alábbiakban rendelkezik:

Vtv. 38. § (1) A vadászati év az év március hónap első napján kezdődik és a következő év február hónap utolsó napjáig tart. A vadászati idény az a naptári időszak, mely a vadászati éven belül kijelöli az egyes vadfajok vadászatának idejét (a továbbiakban: vadászati idény). A vadászati idényt a miniszter - a természetvédelemért felelős miniszterrel egyetértésben - rendeletben állapítja meg.

(2) Azt a vadfajt, amelyre a miniszter vadászati idényt nem állapít meg, a vadászati éven belül kímélni kell (a továbbiakban együtt: vadászati tilalmi idő).

(3) A vadászati hatóság hivatalból vagy kérelemre indított eljárás során - erdőt érintő rész vonatkozásában az erdészeti hatóság, természetvédelem alatt álló területrész vonatkozásában a természetvédelmi hatóság előzetes szakhatósági hozzájárulásával - a vad védelme, az erdészeti és a növényi kultúrák, valamint a mesterséges vizek halállományának védelme, járványveszély és a vad által okozott folyamatos károsítás megelőzése érdekében, továbbá tudományos, oktatási és kutatási célból:

a) a rendeletben meghatározott vadászati idényt meghatározott vadászterületekre meghosszabbíthatja;

b) a rendeletben meghatározott vadászati idényt meghatározott vadászterületekre rövidebb időszakban állapíthatja meg, továbbá

c) a vadászati idényen belül korlátozhatja, vagy megtilthatja egy vagy több vadfaj vadászatát;

d) meghatározott vadfaj túlszaporodása esetén vadászati tilalmi időben vadászatot engedélyezhet, vagy rendelhet el.

(4) Természetvédelmi oltalom alatt álló állatfaj eseti vadászatát - az oltalom feloldása után, a vadászati hatóság előzetes szakhatósági hozzájárulásával - a természetvédelmi hatóság engedélyezi. 
Vhr. 26. § A vadászati hatóság a Vtv. 38. § (3) bekezdésének c) pontja alapján a kötelezettség megszegésével összefüggő eljárása mellett, felszólítást követően vadászati tilalmat is elrendelhet, különösen, ha a jogosult a Vtv. 16-18. §, a 22-25. §, a 28-35. §, 38-39. §, 6971. § és a 82-83. §-okban foglalt kötelezettségeinek nem tesz eleget.

Vhr. 27. § (1) A vadászati idényeket az 5. számú melléklet tartalmazza. A vadászati idény, ha annak kezdete vasárnapra vagy hétföre esik, akkor kiterjed az azt megelőző egy, illetve kettő napra. Ha a vadászati idény vége péntekre vagy szombatra esik, akkor kiterjed az azt követő kettő, illetve egy napra is.

(2) Az 5. számú melléklet II. részében felsorolt vízivad fészkelése és vonulása szempontjából nemzetközi jelentőségű és hazai kiemelt jelentőségű vízi élőhelyeken a vadászati hatóság - védett természeti területet, illetve NATURA 2000 területet illetően a természetvédelmi hatóság szakhatósági hozzájárulásával - szabályozza a vízivad vadászat rendjét. Ebben meghatározza a vízivad vadászatának helyét, módját, idejét, gyakoriságát.

(3) A vadállomány védelme és a vad kímélete miatt vadászati idényre való tekintet nélkül haladéktalanul el kell ejteni a súlyosan beteg és mozgásképtelen, illetve a súlyosan sérült és életképtelen vadat. Az elejtést a vadász, illetve a kísérő köteles a vadászati naplóban „beteg” megjelöléssel rögzíteni, és haladéktalanul bejelenteni a jogosultnak. A jogosult köteles az állat-egészségügyi okból elejtett vadat vizsgálatra alkalmas módon az elejtés helye szerint illetékes hatósági állatorvosnak bemutatni. A hatósági állatorvos az elejtés indokoltságáról külön jogszabály szerinti igazolást állít ki.

(4) A (3) bekezdésben foglaltak kivételével a vad vadászati idényen kívüli - vadászati hatóság engedélye nélkül történt - elejtése a vadászat rendje megsértésének minősül.

A vetési lúd vadászidénye október 1.-január 31. közötti (123 nap), de Hajdú-Bihar, Békés és Csongrád megye teljes közigazgatási területén, valamint Jász-Nagykun-Szolnok megye tiszántúli részén csak december 1.- január 31. között (62 nap) lehet rájuk vadászni. Mindennek elfogadható indoka a globálisan veszélyeztetett, a Tiszántúlon megjelenő kis lilik (Anser erythropus) kötelező kímélete, a téves lelövések pótolhatatlan károkozásának és az abból fakadó konfliktusoknak a megelőzése. Libákból naponta, személyenként összesen legfeljebb hat darab ejthető el, amelyből a nyári ludak száma nem lehetett több kettőnél, azaz akár 6 vetési lúd is elejthető személyenként.

A nagy lilik korábban külön engedélyhez kötött vadászata megszünt, vadászidénye október 1.-január 31. közötti (123 nap). A kis lilik védelme szempontjából - hasonlóan a vetési lúdnál elmondottakhoz - helyi vadászati tilalomhosszabbítás történt, amelynek értelmében Hajdú-Bihar, Békés és Csongrád megye teljes közigazgatási területén, JászNagykun-Szolnok megye tiszántúli területén csak december 1.- január 31. között (62 nap) tart a vadászata. Libákból naponta, személyenként összesen legfeljebb hat darab ejthető el, amelyböl a nyári ludak száma nem lehetett több kettőnél, azaz akár 6 nagy lilik is elejthető személyenként.

A nyári lúd vadászata 2012 óta engedélyezett október 1-december 31 . között (92 nap). A nyári lúdból, vetési lúdból és nagy lilikből naponta, személyenként összesen legfeljebb hat darab ejthető el, amelyből a nyári ludak száma nem lehetett több kettőnél. A nyári lúd vadászati idénye Hajdú-Bihar megye teljes közigazgatási területén, valamint JászNagykun-Szolnok megye tiszántúli területén, december 1-én kezdődik és december 31-éig (31 nap) tart.

A tőkés réce 2012 óta a kizárólagosan vadászható récefaj, vadászati idénye augusztus 15. -január 31. közötti (170 nap), de augusztus 15-től augusztus 31 -ig kizárólag húzáson és a vízparttól - azaz a vízzel borított terület és a szárazföld találkozásától - számított 50 méteren kívül szabad vadászni. A későbbi kezdés és a védőzóna biztosítja a kifejletlen fiatalok, azaz költő állományunk, továbbá a vedlésben lévő „lohos” példányok védelmét, a vadászat pedig valóban a repülőképes példányokat érinti. Lehetőségként a tenyésztett tőkés réce napi terítékkorlátozás nélkül, tilalmi időben is lőhető, ami a természetes populációk védelmét is szolgálja.

A böjti réce Európában sebezhető faj, fészkelő és vonuló állományunk is csökken. Annak ellenére, hogy hazai terítéke nem volt számottevő, előbb vadászható faj státusa fenntartása mellett, vadvédelmi okokból - csatlakozva a védelmét biztosító európai törekvésekhez - egész éves vadászati tilalom alá vonták (2007), majd védetté nyilvánították.

A csörgő réce vadászati idénye 2011-ig ugyancsak szeptember 1.- január 31. közötti (153 nap), hasonlóan a tőkés récéhez, 2012-ben védetté nyilvánították. 

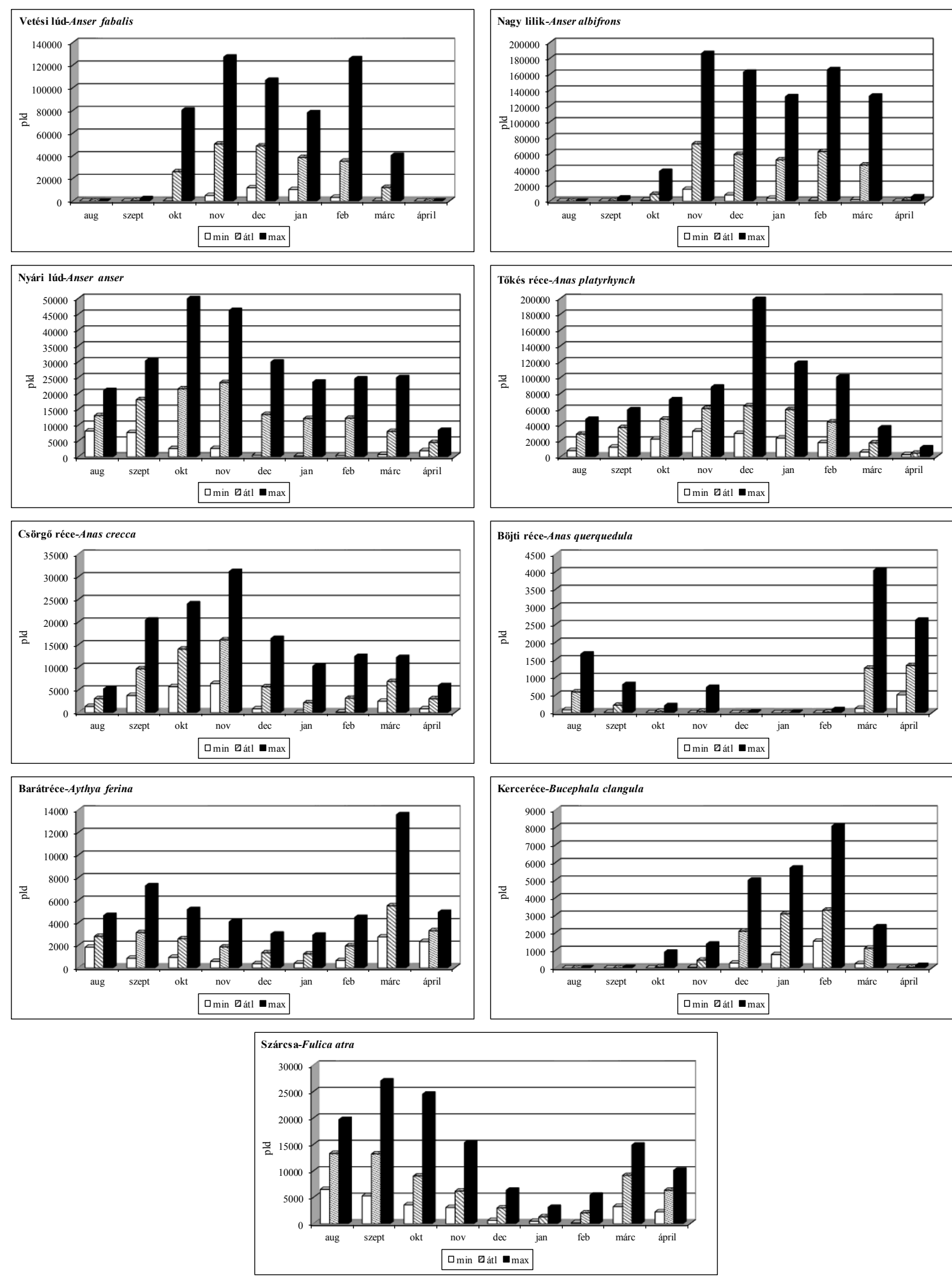

\section{3. ábra: A vadászható vízivadfajok fenológiája Magyarországon}

Figure 33: Phenology of huntable waterfowl species in Hungary

A barátréce cigányrécével való összetéveszthetősége (és részben átfedő élöhely igényük) miatt - ami utóbbi fajt veszélyezteti, nemkülönben jogi konfliktusok forrása - 
vadászidénye később, október 1.-én kezdődött, de változatlanul január 31.-ig (123 napig) tartott. 2008-ban védetté nyilvánították.

Mivel a kerceréce vonuló állományai október végén jelennek meg hazánkban, azért a korábbi augusztus 1.-i idénykezdés értelmetlen volt. Valós lehetőségeinket visszatükrözte az október 1.-január 31. közötti (123 napos) vadászidény. Valamennyi fajra, így rá is érvényes volt a naponta, személyenként összesen legfeljebb 8 példány elejtését lehetővé tevő terítékkorlátozás. 2012-ben ezt a fajt is védetté nyilvánították.

A szárcsa vadászatának szabályozása mindig egybeesett a tőkés récére vonatkozó elöírásokkal, már csak azért is, mert Magyarországon a tőkés réce mellett a leggyakoribb faj. Mivel fészkelő és vonuló állománya stabil, azért vadászati idénye - a tőkés récénél megfogalmazott indokokkal - szeptember 1.-január 31.- közötti (153 nap). Naponta, személyenként összesen legfeljebb 8 szárcsát lehetett elejteni.

A vízivad fészkelése és vonulása szempontjából nemzetközi jelentőségű és hazai kiemelt jelentőségü vízi élőhelyeken a vadászati hatóság - védett természeti területet, illetve NATURA 2000 területet illetően a természetvédelmi hatóság szakhatósági hozzájárulásával szabályozza a vízivad vadászat rendjét. Ebben meghatározza a vízivad vadászatának helyét, módját, idejét, gyakoriságát. Ezek az ún. vízivad kíméleti területek (lásd korábban).

A vadászati idények hossza - kezdete és vége - megfelelnek a mennyiségi dinamikáknak (33. ábra) és gyakorisági sorrendekben (2. táblázat) elfoglalt pozícióknak. Egyetlen többlet kritérium megfogalmazása szorgalmazandó a jogszabályban, nevezetesen annak lehetösége, hogy tartósan (5 nap) $-10^{\circ} \mathrm{C}$ alatti hömérséklet esetén a vadászatot további rendelkezésig fel kell függeszteni, s azt a média útján is közzé kell tenni. A vadászati kíméleti terïletek pedig egyedülálló módon biztosítják a vízivad védelmét.

\subsubsection{A vadászati módszerek}

A vízivad vadászati módszerek és eszközök vonatkozásában, mindenkor a Berni Egyezmény IV Mellékletében felsorolt előírásokat tartja be a magyar vadászati jogi szabályozás. Ennek értelmében

Vtv. 71. § (1) A vadászat rendje megsértésének minősül az alábbi vadászat:

a) a légi jármüből, mozgásban lévő motoros jármüből vagy jármüről, továbbá az óránként öt kilométert meghaladó sebességgel közlekedő vízi jármüböl,

b) a vízivad vadászatának kivételével a lesgödörböl,

c) a vízivad vadászatának kivételével a vízi jármüröl,

d) a fényszóró engedély nélküli használatával, valamint

g) az érintett vadászatra jogosultak közötti megállapodás hiányában a szomszédos vadászterület határától számított háromszáz méteren belüli lesvadászat,

h) vadászati idénytől függetlenül az olyan időpontban történő vadászat, amikor a vad menekülési lehetősége bármilyen természeti ok miatt jelentősen korlátozott,

(2) A vadászat rendje megsértésének minősül továbbá az alábbi eszközökkel történő vadászat:

a) az önmüködő (automata) és öntöltő (félautomata) golyós löfegyver;

b) az öntöltő (félautomata) sörétes vadászlőfegyver, amelyben egyidejüleg háromnál több löszer van;

e) az elektronikus optikai eszköz;

f) a vad megtévesztésére alkalmas elektronikus akusztikai eszköz;

g) a vad megtévesztésére alkalmas mesterséges szaganyag, valamint megcsonkított élő csali állat.

Vhr. 75/A. § (1) A Vtv. 71. § (2) bekezdésének b) pontja szerint vadászat rendje megsértésének minősül a két tölténynél nagyobb tárkapacitású (amelyben egyidejüleg háromnál több lőszer tartható) félautomata (öntöltö) sörétes vadászlőfegyver tár reduktor nélküli használata.

(2) A Vtv. 71. § (2) bekezdésének e) pontja szerint nem minösül elektronikus optikai eszköznek a céltávcsőben célzás megkönnyítése céljából elektronikusan megvilágított irányzék. 
Az 56/2005 (VI.25.) FVM Rendelet rendelkezik arról, hogy mely vizes területeken tilos az ólomsörét használata (részletes felsorolást lásd a 4.1.4. fejezetben)

A magyar jogszabályok a vadászati módokat illetően mindenben megfelelnek a hatályos egyezményekben vállaltaknak és az EU elöirásainak.

\subsubsection{Vadászati statisztika, terítékadatok}

A magyar vadászat abban a különleges helyzetben van, hogy vadlelövési statisztikák már az 1880-as évekből rendelkezésre állnak a MAGYAR STATISZTIKAI HivATALt megszervező és elsőként igazgató KELETI KÁROLY akadémikus jóvoltából, aki egyúttal alelnöke volt az ORSZÁGOs MAGYAR VADÁSZATI VÉDEGYLETNEK. Neki köszönhetjük, hogy a statisztikai adatszolgáltatás a vadászat területén is megvalósult és kiteljesedett a XIX. század végén, Magyarországon, s Európában egyedülálló módon vadfajonként és megyei bontásban rendelkezésre állnak a terítékadatok. Az 1960-as évektől előbb a MÉM majd az FM Vadászati és Halászati Főosztálya szervezte a statisztikai adatgyüjtést és az adatok feldolgozását, amit a szaksajtó útján tettek közzé. Ennek vízivadra vonatkozó feldolgozása is megtörtént, azzal a korláttal, hogy az adatszolgáltatás során nem történt meg a faji bontás, így csak „libákat” és csak „récéket” lehetett elemezni (FARAGÓ, 1982a).

A vad védelméröl, a vadgazdálkodásról és a vadászatról szóló törvény ORSZÁGOS VADGAZDÁlKODÁSI ADATTÁR (OVA) létrehozását és müködtetését rendelte el. A vadállomány nagyságának és a vadgazdálkodás eredményességének megítélését hagyományosan az éves vadállomány becslési jelentések, a vadgazdálkodási jelentések és a trófeabírálati eredményekről közzétett összesítések szolgálták, az OVA adatközlései is ezt a gyakorlatot követik.

A változás a korábbiakhoz képest, hogy éppen az AEWA alapján kidolgozott MAGYAR VÍZIVAD GAZDÁLKODÁSI TERV kidolgozása során javasoltuk a főhatóságnak a teljes körü és faji szintü statisztikai (teríték) adatszolgáltatás kötelezettségét (FARAGÓ, 1997a). Korábban külön mintavételen alapuló vizsgálattal határoztuk meg a teríték fajspektrumát (FARAGÓ, 1988). 1994 óta az Országos Vadgazdálkodási Adattár évente teszi közzé a fajonkénti és területenkénti (megyék) vízivad terítéket (CSÁNYI, 1999; 2000; 2001; 2002; 2003; 2004; 2005; CSÁNYI et al 2006; 2007; 2008; 2009; 2010; 2012a; 2012b; 2013; 2014; 2015; 2016), illetve rendszeresen megtörtént az éves terítékek értékelő elemzése is (FARAGÓ \& RITTER, 1998; 1999; FARAGÓ et al., 2001; 2002a; 2002b; 2003; LEHOCZKI \& CSÁNYI 2006; 2007; 2008; 2009; 2010; 2012a; 2012b) ). A védelmi szempontból hazai érzékenyebb vadlúd vadászat elemzését az utóbbi időszakban rendszeresen közzé tettük (FARAGÓ, 2001c; 2005c).

Az ilyen mélységü feldolgozások nagyon ritkák Európában, de a világon is. Elsősorban a volt szocialista országokban (talán a tervgazdálkodáshoz szükséges permanens adatszolgáltatási kényszer következményeként), illetve Dániában, Németországban, Svájcban és Ausztriában körültekintő az adatgyüjtés, illetve annak közzététele. Kanadában és az Egyesült Államokban is rendszeresen közzé teszik a NATIONAL HARVEST SURWEY eredményeit, legutóbb 1985-1998 időszakára vonatkoztatva (BOYD et al., 2002). Angliában mintavételen alapuló terítékbecslést - NATIONAL GAME BAG CENSUS - vezettek be, így az abszolút egyedszámok helyett a terítéksürüséget és a dinamikát állapítják meg (TAPPER, 1992), az eredmények közzététele is alkalmi. Franciaországban ritkán végeznek a teríték nagyságára/sürüségére vonatkozó elemzést. Az 1974/1975, majd az azt követő 1983/1984-es vadászati idény után 15 évvel, az 1998/199-es szezonban történt kérdőíves felmérés, ami nem volt teljes körü, így ugyancsak tájékoztató adatokat adott (LANDRY \& MiGOT, 2000). Sajnálatosan kedvezőtlen a helyzet a szovjet utódállamokban és a Balkánon, ahol korábban és napjainkban is vagy hiányos az adatközlés, vagy az adatok teljesen megbízhatatlanok. 
Bármiféle összefoglaló munka, amely a Nyugat-Palearktisz vadászati terítékeit kívánta feldolgozni (pl. LANDRY, 1990a; MoOIJ, 2005) legalább háromféle akadályba ütközött. (1) a vadászható fajok eltérő száma, (2) az eltérő statisztikai adatgyüjtési módok (LANDRY, 1990b), (3) a rendszeres adatgyüjtés hiánya.

Így - bármilyen furcsa kijelenteni - amíg a becslésekből egyre jobban ismerjük az állománynagyságokat, addig a hasznosítás mértéke hihetetlenül bizonytalan, ami a vadászható fajok hatékony védelmét rendkívül megnehezíti.

Mindezek után és a hazai ismeretek alapján megállapítható, hogy Magyarországon a vízivad vadászat statisztikai adatszolgáltatása, nyilvántartása és elemzése talán egyedülálló rendszerességü és területi lefedettségü Európában, eredményei pedig folyamatosan beépülnek a szabályozás rendszerébe.

\section{AJÁNLÁSOK A HATÉKONYABB VÍZIVAD VÉDELEMHEZ ÉS GAZDÁLKODÁSHOZ}

Vizes élőhelyeink (státusuktól függetlenül) - területi visszaszorulásuk következtében kisebb-nagyobb szigetek a szárazulat mátrixában. A vizes élőhelyekhez kötődő madárfajok, köztük a vízivad fajok - többségük viszonylag tág ökológiai valenciája mellett - elfoglalják és belakják e területeket, amelyeket magterületeknek nevezhetünk. A Kárpát-medence ökológiai viszonyai között azonban a vízimadaraknak részben a nyár folyamán (diszmigráció), részben a nyár végén és ősszel (migráció) el kell hagyniuk bizonyos asztatikus vízháztartású területeket, mert azok - kiszáradás, jegesedés, táplálékhiány stb. miatt. - alkalmatlanokká válnak a populációk, fajok, közösségek maradéktalan eltartására.

A diszmigráció során a legökonomikusabb, ha a legközelebbi alkalmas élőhelyet választja az adott egyed, vagy csoportosulás. Ennek az elmozdulásnak a feltétele a kapcsolatok megléte, az alternatív helyek/magterületek ismerete, amit tapasztalás útján szereznek meg a populációk. A vizes magterületeket ily módon légifolyosók kötik össze. Mivel a légifolyosók nem kapcsolódnak feltétlenül vegetációhoz, ezért elgondolkodtató, hogy ezt az útvonalat nevezhetjük-e ökológiai folyosónak, mint ahogy a populációknak, fajoknak (mint szünbiológiai objektumoknak) a magterületeket összekötő élöhelyfolyosóit általában nevezzük. Különösen igaz ez a megállapítás a nagyobb testü vízivad fajokra. Az élőhelyváltozás kiváltotta diszmigrációhoz hasonló jelenség játszódik le zavarás hatására is. Vadászat, gazdálkodási, vagy rekreációs tevékenység következtében egy közeli helyen kell létfeltételeket találnia a vízivad csapatoknak.

A migráció, azaz az őszi és tavaszi madárvonulás során a környezeti nyomás és a kiváltó hormonális mechanizmusok eredőjeként, genetikailag is determinált elmozduláskényszer manifesztálódik, ahol a nagy távolságok megtétele során - bár kétségtelen, hogy a terepalakulatoknak van vonulást vezető szerepük - az egyedeknek, csapatoknak elsősorban jó, táplálékban gazdag és nyugodt pihenőhelyekre van szükségük, míg két pihenőhely közti légi út nehezen interpretálható ökológiai folyosóként.

Úgy tünik tehát, hogy a vízivad esetében inkább a „tipegö kö” (stepping stone) jellegü élöhely hálóval tudjuk leképezni a valós térhelyzetet. Természetesen előny, ha ennek a hálónak minél kisebbek a hálószemei, azaz minél közelebb vannak a magterületek (a kövek) egymáshoz, s nem baj az sem, ha a kapcsolatot vízfolyások teszik folyamatossá, hiszen az bizonyos időszakokban (pl. lohosodás) a mozgást is megkönnyíti. Nem véletlen, hogy az Alföldön a nyárvégi időszakban a hosszan elnyúló, könnyen elérhető és mindenhez jól kapcsolódó Tiszán gyülekeznek a récék, a lohosodás időszakában. Az ilyen élőhely-szerkezet a fészkelö fajok esetében a ,foltos" (patchy) szerkezetü metapopulációk kialakulását teszik 
lehetővé, ahol a közeli foltok közötti migráció gyakori jelenség, ezért hosszútávon összefüggő demográfiai egységként is müködnek (FARAGÓ \& NÁHLIK, 1997).

A vizes élőhelyek hálózata tehát egy különleges státusú rendszer, hiszen egyik oldalról az immobilis (pontosabban csak a propagulumaival mobilis) növények, a lassan mozgó, terresztris állatok (ízeltlábúak, kétéltüek, hüllők, emlősök zöme) számára klasszikus magterületként szolgál (NÉMETH, 1995) - a környező területek puffer funkciói mellett. Másik oldalon a mobilis populációk, elsősorban madárfajok esetében a magterület jelleg fennmarad, de a „tipegő kö" funkció egyfajta gyors menekülést biztosít. Előbbi fajok számára tárgyiasult formájú valós korridorokra, ökológiai folyosókra van szükség a kapcsolattartás és az elmozdulás lehetőségének fenntartása miatt. E folyosók között fontos szerepet játszanak a folyók és ártéri vegetációjuk, amire vonatkozóan hazai bizonyítékokkal GALLÉ (2003) szolgált a Tiszára vonatkozóan.

A vízimadarak esetében a szakirodalom (lásd KALCHREUTER, 1987) a récék napi akciórádiuszát 30-50 $\mathbf{k m}$-nek adja meg. Abban az esetben tehát, ha valamilyen kényszer (élöhely romlás vagy vesztés, zavarás) hatására időlegesen, vagy tartósan el kell hagyniuk területüket, akkor kedvezö, ha alternatív területet ilyen távolságban találnak. Az új terület azonban nem feltétlenül jobb terület is, lehet, hogy átmeneti jóságát csupán a nyugalom biztosítja. Ha a korábban használt zavart területen a diszmigrációt kiváltó ok megszünik, akkor a madarak visszatérnek a kedvezőbb - mindenekelött - táplálkozási körülmények közé.

A vízivad fenntartására tehát mindenekelött vizes élöhely hálózatra van szükség. A Nemzeti Ökológiai Hálózat (NÉMETH, 1995) élőhely hálózat a természetes élöhelyek hálózatának és kapcsolatrendszereinek megőrzésében látja a biodiverzitás fenntartásának megoldását. Alapelvként ezt elfogadva a vízivad populációk fenntartása érdekében mégis egy alternatív - az előbbinek nem ellentmondó - „tipegö kö” funkciójú vizes élőhely hálózat kialakítására és fenntartására teszek javaslatot.

A hálózat tagjainak alapismérvei a nyugalom, a diverz élőhely szerkezetet feltételező kedvezö táplálékellátottság. Hazai vizes élőhelyeink trofitása, azon keresztül a vízivad számára biztosított táplálék forrás kínálata magas, különösen a sekélyvizü víztípusokban (leginkább a halastavakban és tározókban). A nyugalmat pedig a vízivad kíméleti területek (3. térkép) biztosítják, amelyek maguk is megfelelnek az előző kritériumoknak.

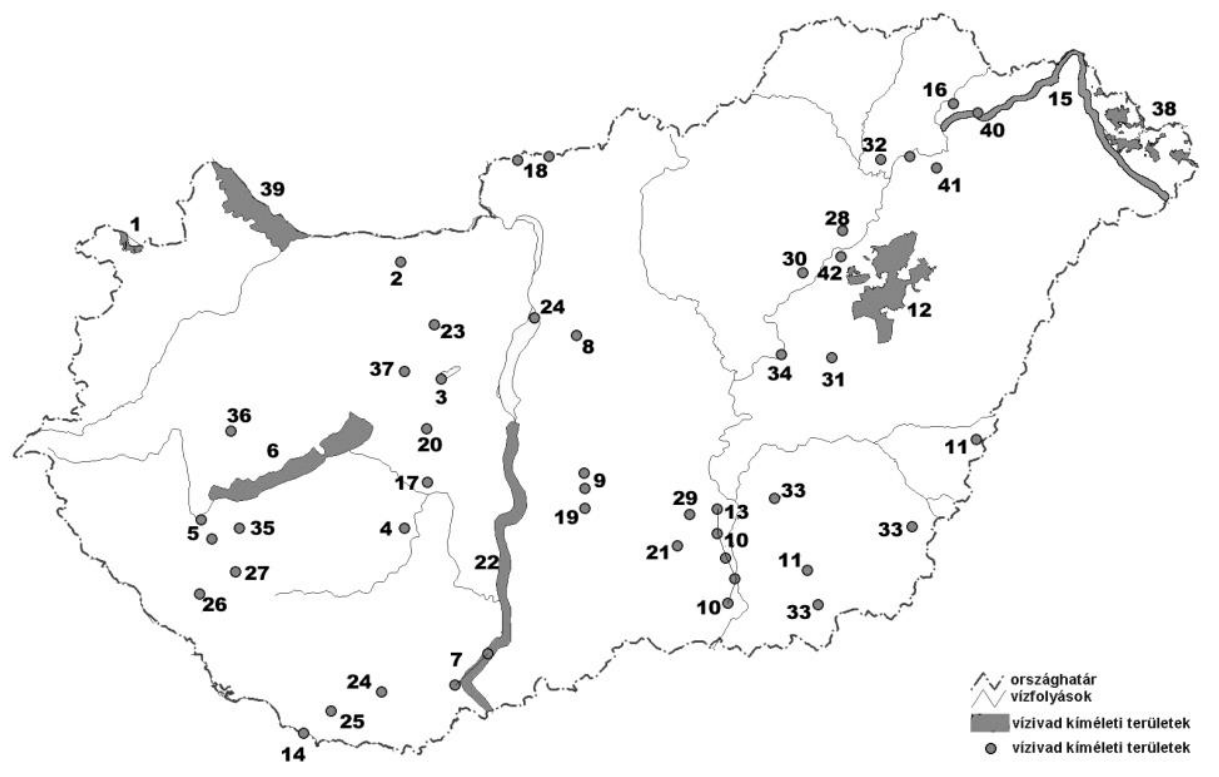

3. térkép: A vízivad kíméleti területek elhelyezkedése Magyarországon Map 3: Locations of all-year round close season areas in Hungary 
A vízivad kíméleti területekre alapozott hálózat kialakításának fázisait az alábbi térképsoron illusztráljuk. A 4. térképek mutatják a kíméleti területek 30 és $\mathbf{5 0} \mathbf{~ k m}$ átmérőjü körökkel jelzett hatóköreit. Könnyü belátni, hogy ha a szomszédos körök érintkeznek egymással, akkor a vízivad 30, illetve $\mathbf{5 0} \mathbf{~ k m - r e ~ t a l a ́ l ~ m a g a ́ n a k ~ a l t e r n a t i ́ v ~ e ́ l o ̋ h e l y e t ~ ( a z ~} \mathbf{5}$. térkép a két távolságot egy térképen mutatja).

Természetes, hogy a két alternatíva között ideális eloszlás mintázat esetében mintegy 40\%-nyi területdifferencia lehet (amennyiben az élőhelyek távolsága homogén lenne). A két változat közül a nagyobb biztonságot (a túlélés és a visszatérés biztonsága értelmében) a 30 km-es alternatíva jelenti, hiszen minél hosszabb időt töltenek a vízivad csapatok a vadászattól mentes területen, annál biztosabb lesz a túlélés.
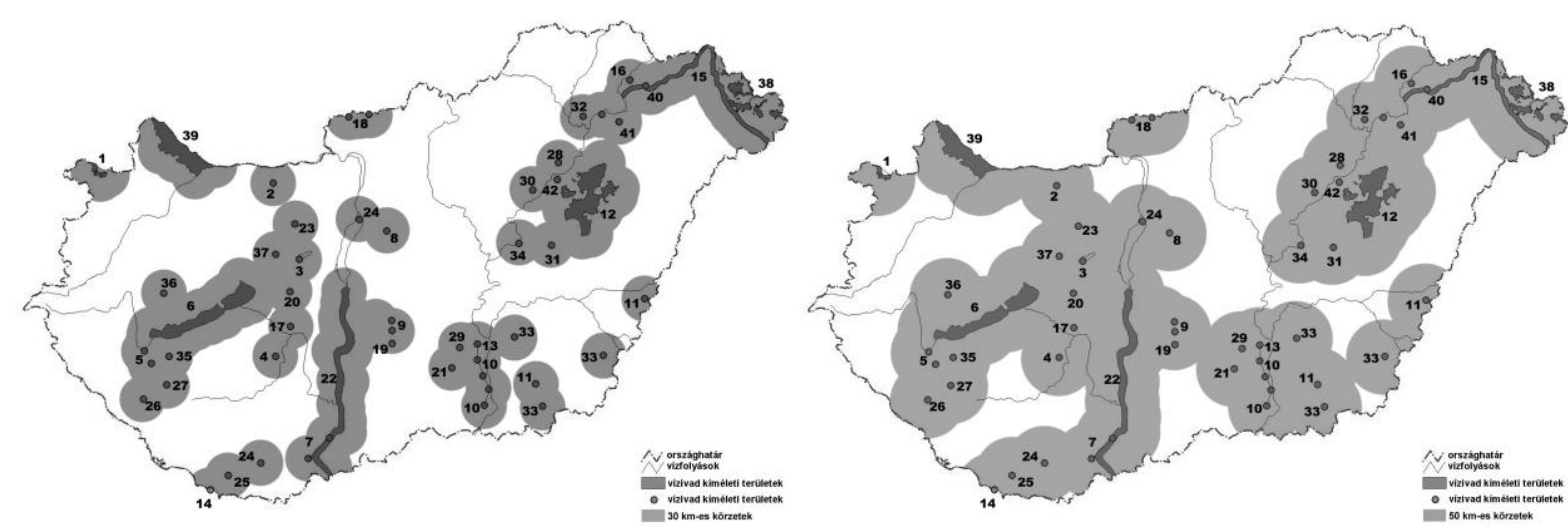

4. térkép: Vízivad kíméleti területek a $30 \mathrm{~km}$-es (bal) és $50 \mathrm{~km}$-es (jobb) körzetekkel Map 4: All-year round close season areas with $30 \mathrm{~km}$ (left) and $50 \mathrm{~km}$ (right) zones

A térképek azt is megmutatták, hogy a kíméleti területek országon belüli elhelyezkedési mintázata távolról sem ideális. A kapcsolódó „tipegő kövek” a magasan erdősült hegyvidéki területekről hiányoznak leginkább, de érdekes módon jelentős hiátusok vannak a NyugatDunántúlon és a Duna-Tisza közén is (5. térkép). Az így létrejött „üres terekbe” vizes „tipegő köveket" kell telepítenünk, azaz újabb kíméleti terïleteket kell létesíteni. A vízivad a nyugalmat jelentő új területeket hamar felismeri (rezervátum effektus), s elfoglalja, belakja azokat.

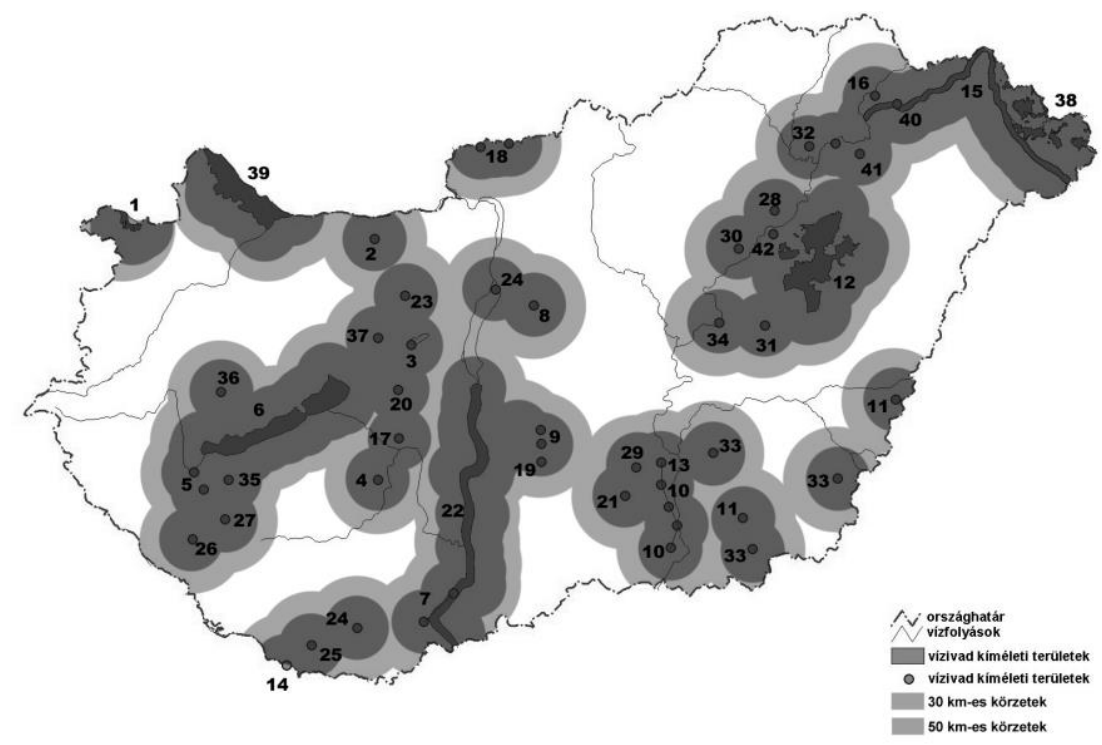

5. térkép: A vízivad kíméleti területek a 30 és $50 \mathrm{~km}$-es hatósugarakkal

Map 5: All-year round close season areas with $30 \mathrm{~km}$ and $50 \mathrm{~km}$ zones (depicted together) 


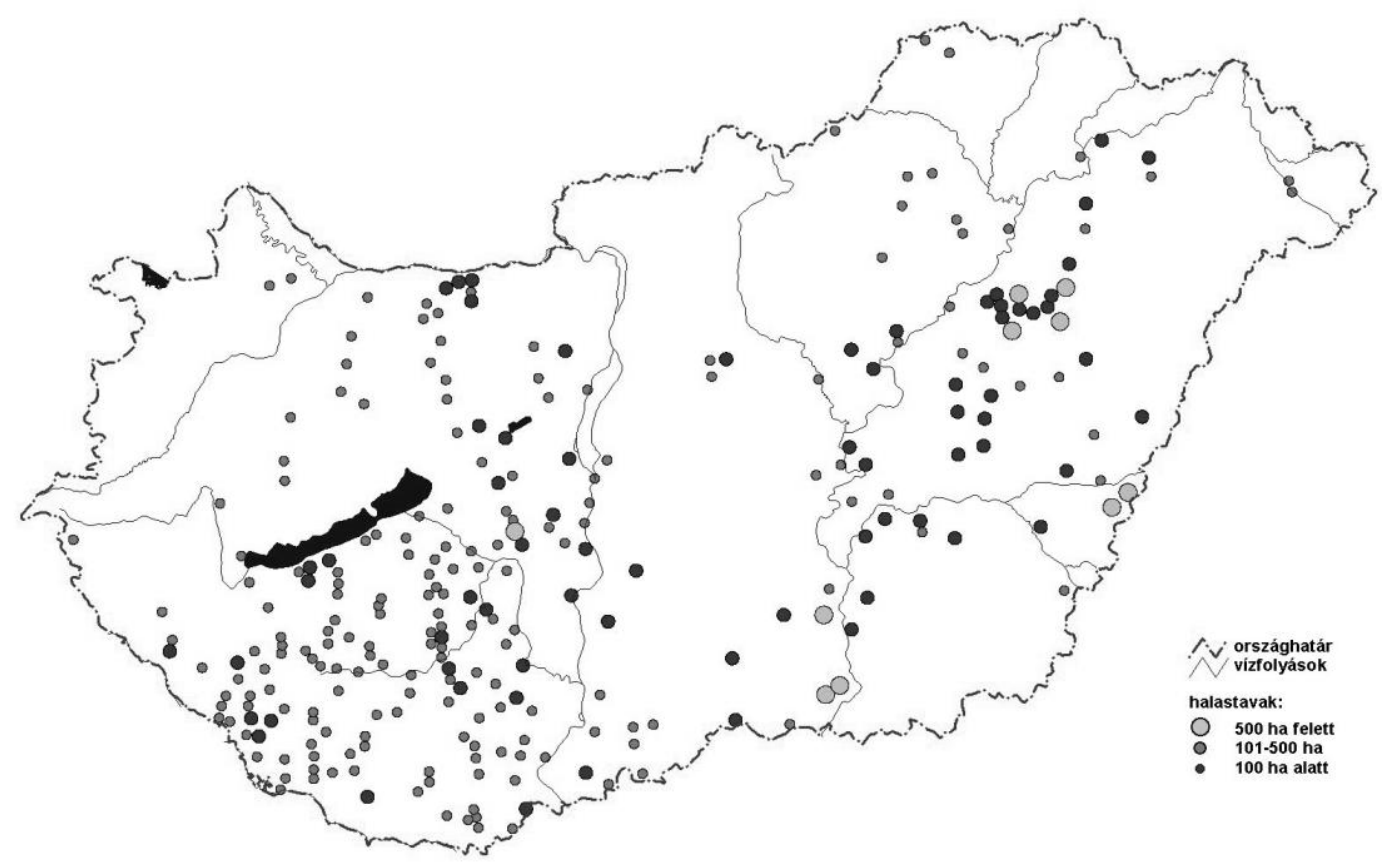

6. térkép: A halastórendszerek elhelyezkedése Magyarországon Map 6: Locations of fishpond systems in Hungary

De honnan tudunk új vizes élőhelyeket elöteremteni, különösen olyanokat, amelyek kedvezőek is a vízivad számára. Ismerve a vízivad élőhely preferenciáit (FARAGÓ, 2011e) egyértelmü, hogy első megközelítésben a 80-100 hektáros minimális vízfelszínt biztosító halastavak körében kell a megoldást keresnünk. A magyarországi halastavak hálózata (6. térkép) első látásra is mutatja, hogy - bár a mintegy 30000 hektár összterületü halastó kiterjedt területeket tárhat fel - kizárólag ezzel a módszerrel sem juthatunk el a teljes lefedettséghez. A Dél-Dunántúl és a Dél-Alföld halastavakra alapozott kíméleti terület sürítésével lehet eredményt elérni, a két nagy „fehér folt”, a Kisalföld D-i része és a Hernád völgye térsége csak egy-egy, a Rába és a Hernád árterületeihez köthető élőhely rekonstrukcióval adna végleges megoldást (7. térkép). 


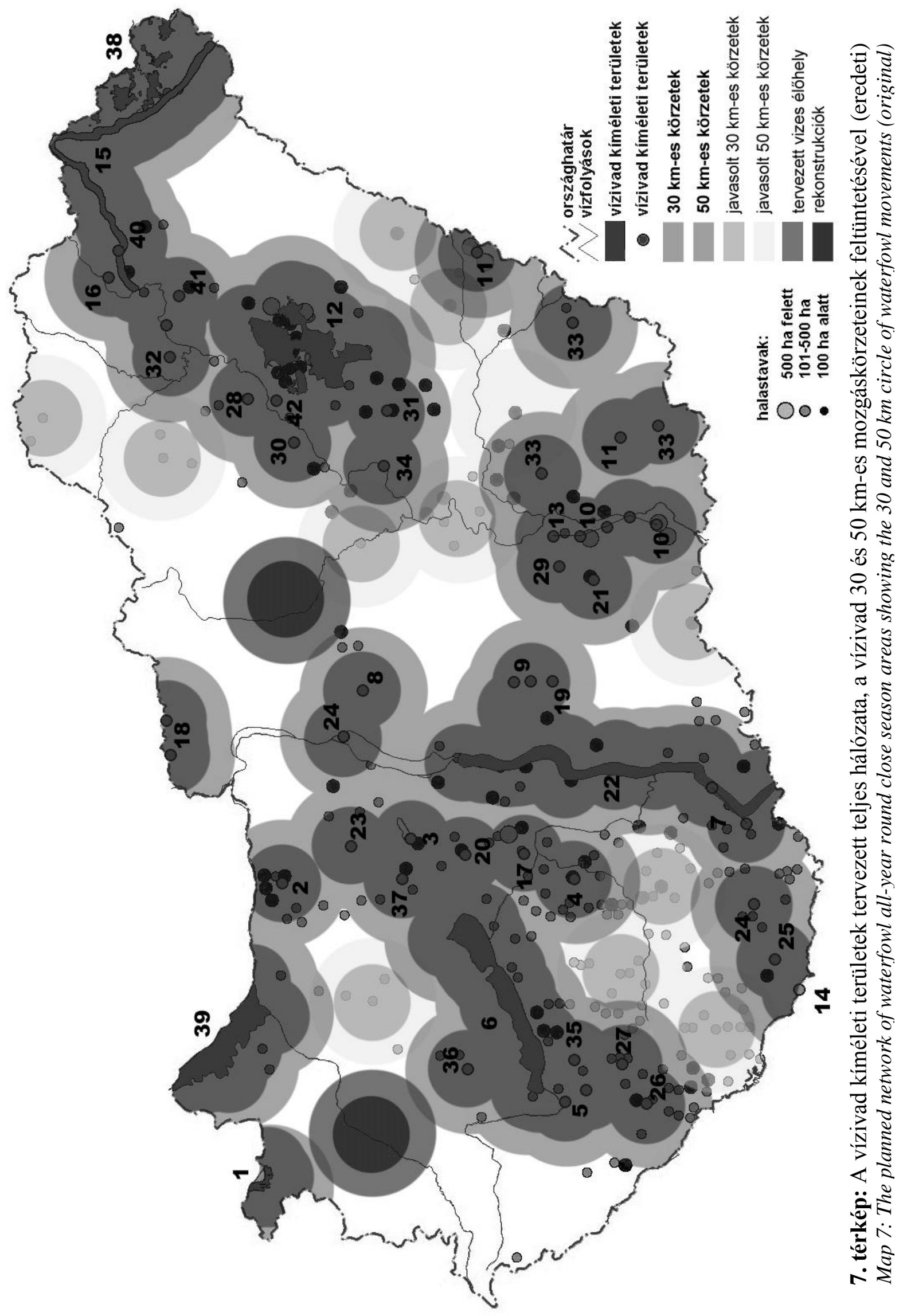




\section{EREDMÉNYEK ÖSSZEFOGLALÁSA ÉS KÖVETKEZTETÉSEK}

A hazai vízivad vadászati hasznosítását összefoglalva az alábbi megállapításokat tehetjük:

(1) Kimutattuk a három vadászható vadlúdfaj eltérő állomány- és terítékalakulása közötti kompenzáló hatást, amely végső soron a magyar vadlúd terítéknek jelentős növekedését eredményezte a növekvő nagy lilik és nyári lúd állományok következményeként. Megállapitottuk, hogy a növekedést támogatja, de egyúttal korlátozza is a szigorú és többoldalú vadászati szabályozás.

A 2012 óta vadászható nyári lúd terítékét négy vadászidény alapján érdemben nem tudjuk még értékelni. A négy terítékértékről - 2012: 1800 pd; 2013: 1752 pd; 2014: 1513 pd és 2015: 2677 pd - ismételve kijelenthető, hogy biztosan a 15\%-is kritikus érték alatti, tehát fenntartható hasznosítást jelent.

Megállapitható, hogy Magyarországon a nagy lilik és a nyári lúd védelme és vadászata a bölcs hasznositás szellemében történik, a vetési lúd esetében a hivatalos statisztikákban megjelenitett vadászati teritéke eléri a becsült létszámot, ami lehetetlen és tarthatatlan, a becslések alapján országos teritéke maximum 300-350 példány lehetne!

(2) Magyarországon, a tőkés récén kívül korábban vadászható csörgő récének (3-6\%) és barátrécének $(1-4 \%)$ volt, a böjti récének és a kercerécének $(<1 \%)$ gyakorlatilag nem volt vadászati jelentősége. A récefajok és a szárcsa állománydinamikájának területi differenciálódása jól megmutatkozott a terítékben is, azaz a csörgő réce, a böjti réce, a barátréce és a kerceréce és a szárcsa állománycsökkenései a terítékeik csökkenéséhez, ezáltal a tökés réce teríték arányainak relatív növekedéséhez vezetett. A csörgő réce, a böjti réce, a barátréce és a kerceréce állományainak visszaesése elvezetett vadászható faj státusok megszüntetéséhez, védetté nyilvánításához. Utóbbi négy faj védetté nyilvánítása után a tőkés récén kívül, - a három libafaj mellett - már csak a szárcsa vadászható, terítéknagyságban kimutatható vadászati szerepe azonban eltörpül (3-4\%) a tőkés réce mellett.

Az 1993-ban életbe lépett vízivad vadászati rendelkezések nemcsak a vadászati módokban és a napi, személyenkénti teríték limitben teremtettek új helyzetet Magyarországon, hanem az ún. kíméleti területek hálózatának kialakításával is. Javaslatunkra akkor 10, ma 40 ilyen terület van Magyarországon. Mindezek alapján megállapitható, hogy összhangban a Bonni Konvenció és az AEWA ajánlásaival - Magyarországon a vízivad vadászata a bölcs hasznositás szellemében történt és történik.

(3) A vízivad fajok országosan megfigyelt havi mennyiségeinek átlagos rangsorrendje alapján a leggyakoribb vadászható vízivad fajok a vadászidényben az alábbiak:

$\begin{array}{ll}\text { ANAPLA (szept. - jan.) } & 1,1-2,0 \text { átlagos rangsor hely } \\ \text { ANSALB (okt. }- \text { jan.) } & 1,4-6,4 \\ \text { ANSANS (okt. }- \text { dec.) } & 2,8-3,8 \\ \text { FULATR (szept. }- \text { jan.) } & 2,8-8,6 \\ \text { ANACRE (szept. }- \text { jan.) } & 3,7-8,2 \\ \text { ANSFAB (okt. }- \text { jan.) } & 4,2-10,0 \\ \text { BUCCLA (okt. - jan.) } & 6,2-31,7 \\ \text { AYTFER (okt. }- \text { jan.) } & 9,5-11,3 \\ \text { ANAQUE (szept. }- \text { jan.) } & 18,2-37,8\end{array}$

Az 5 napjainkban vadászható vízivad faj állományainak ismeretében elmondható, hogy általában a leggyakoribb magyarországi vízivad fajokat érinti a hasznositás, igy ebben a 
vonatkozásban maradéktalanul megfelel jogi szabályozásunk a nemzetközi elvárásoknak és a bölcs hasznositás elvének. Ki kell emelnünk azonban a vetési ludat, amelynek utóbbi idöben észlelt drámai mértékü állománycsökkenése vadászatának felfüggesztését igényli.

Az értékelés során azonban az is szembetünő, hogy a ranglista elején helyezkednek el nagy gyakoriságú védett fajok is, amely legalábbis kérdésessé teszi az előbb ismertetett és elismert logika teljes körü érvényességét és érvényesülését. Ezek, gyakoriságuk és vadászidényen belüli tartamosságuk (hónapok száma) alapján rendre az alábbiak: kárókatona, kanalas réce, fütyülö réce, kontyos réce, szürke gém, búbos vöcsök, kendermagos réce és cigányréce. A nyári lúd az az egyedüli korábban védett faj, amelynek magas rangsorbeli helyezése 2012-ben elvezetett védelmének feloldásához. A felsorolt fajok közül biztosan nincs vadászati érdeklődés a kárókatonára, a szürke gémre és a búbos vöcsökre. Globálisan veszélyeztetett faj a cigányréce, tehát vadászata szóba sem kerülhet. A fütyülő réce, a kontyos réce és kendermagos réce esetében - csökkenő állománydinamikájuk okán - nincs napirenden vadászhatóvá tétele.

(4) A kibocsátott tőkés récék megoszlása a régiók között lényeges változást mutatott ezen időszakban $(1995 \rightarrow 2015)$, amennyiben az abszolút értékek általános csökkenése mellett, a relatív értékek nőttek a Tiszántúlon $(31 \rightarrow 63 \%)$ és Észak-Magyarországon $(15 \rightarrow 17 \rightarrow 22 \%)$, másutt azonban mindenütt csökkenést lehetett kimutatni (Észak-Dunántúl: $21 \rightarrow 12 \%$; DélDunántúl: $19 \rightarrow 10 \%$; Duna-Tisza köze: $12 \rightarrow 3 \%$ ). Történt mindez annak ellenére, hogy a Dunántúlon és a Duna-Tisza közén a tőkés réce tenyésztésére többszörösen nagyobb területek állnak rendelkezésre (a Dunántúlon 21000 ha, a Duna-Tisza közén 15200 ha), mint a Tiszántúlon (8700 ha). A tőkés réce tenyésztése és kibocsátása a vadgazdálkodók gazdasági helyzetének a függvénye, s nem feltétlen az ökológiai-tenyésztési potenciál által megszabott tevékenység. A természetes élőhelyek kímélete és a szabadterületi vízivad állomány-gazdálkodás mellett és azzal összhangban - figyelembe véve a piaci igényeket és a gazdálkodói lehetőségeket -, támogatható a félvad és elfogadható az intenzív tőkés réce nevelés fenntartása. A genetikailag tiszta, betegségektől mentes kibocsátott (pl. röptetett) tőkés réce vadászata - gazdaságossága mellett - csökkenti a vadászati nyomást a vad populációkban, s csökkenti a természetes élőhelyeken a zavarásból eredő veszteségeket. A vadászat módját és mértékét azonban összhangba kell hozni a társadalom egyre érzékenyebb állatvédelmi értékrendjével.

(5) A vadászati idények hossza - kezdete és vége - megfelelnek a mennyiségi dinamikáknak és gyakorisági sorrendekben elfoglalt pozícióknak. Egyetlen többlet kritérium megfogalmazása szorgalmazandó a jogszabályban, nevezetesen annak lehetösége, hogy tartósan (5 nap) $-10^{\circ} \mathrm{C}$ alatti hömérséklet esetén a vadászatot további rendelkezésig fel kell függeszteni, $s$ azt a média útján is közzé kell tenni. A vízivad vadászati kíméleti területek pedig Európában is egyedülálló módon biztosítják a vízivad védelmét. A magyar jogszabályok a vadászati módokat illetően mindenben megfelelnek a hatályos egyezményekben vállaltaknak és az EU elöírásainak. Magyarországon a vízivad vadászat statisztikai adatszolgáltatása, nyilvántartása és elemzése talán egyedülálló rendszerességü és területi lefedettségü Európában, eredményei pedig folyamatosan beépülnek a szabályozás rendszerébe.

(6) A vízivad fenntartására mindenekelött vizes élőhely hálózatra van szükség. A Nemzeti Ökológiai Hálózat a természetes élőhelyek hálózatának és kapcsolatrendszereinek megőrzésében látja a biodiverzitás fenntartásának megoldását. Alapelvként ezt elfogadva a vízivad populációk fenntartása érdekében mégis egy alternatív - az előbbinek nem ellentmondó - „tipegő kő” funkciójú vizes élőhely hálózat kialakítására és fenntartására teszünk javaslatot. A hálózat egységeinek (sites) alapismérvei a nyugalom, a diverz élőhely szerkezetet feltételező kedvezö 
táplálékellátottság. Hazai vizes élőhelyeink trofitása, azon keresztül a vízivad számára biztosított táplálék forrás kínálata magas, különösen a sekélyvizü víztípusokban (leginkább a halastavakban és tározókban). A nyugalmat pedig a vízivad kíméleti területek biztosítják, amelyek maguk is megfelelnek az előző kritériumoknak. A vízivad eddigi refúgiumainak 30-50 km-es átméröjü védterületei közötti „üres terekbe”, újabb kíméleti területek létesitésére teszünk - térképi megjelenítésük mellett - javaslatot. A vízivad a nyugalmat jelentő új területeket hamar felismeri (rezervátum effektus), s elfoglalja, belakja azokat. A Dél-Dunántúlon és a Dél-Alföldön a vízivad fajok élöhely preferenciái alapján első megközelítésben a 80-100 hektáros minimális vizfelszínt biztositó halastavak körében kell a megoldást keresnünk. A fennmaradó két nagy „fehér folt”, a Kisalföld déli része és a Hernád völgye térségében csak egy-egy, a Rába és a Hernád árterületeihez köthető - a jövőben megtervezendő és megvalósítandó - élöhely rekonstrukció adna végleges megoldást.

Mindezen feladatok pedig csak akkor valósíthatók meg, ha

(a)a védelem gyakorlatában maradéktalanul érvényesülnek az AEWA ajánlásai

(b)a vadgazdálkodás és a természetvédelem kapcsolatát minden szinten az együttmüködés, a közös feladatok közös megvalósítása jellemzi, a közös veszélyek együttes elhárítása érdekében.

(c)bekövetkezik a teljes paradigmaváltás a vízivad gazdálkodásban, illetőleg.

(7) A vadgazdálkodás jövőképe kizárólagosan a természetszerü, bölcs gazdálkodáson alapulhat, amit a már a MAGYAR APRÓVAD GAZDÁlKODÁs STRATÉGIAI TERVE (FARAGÓ, 1999c) megfogalmazott, s amely kiemelt helyen tárgyalja a vízivad védelmét is. EU-s tagságunkból fakadó lehetöségek és kötelezettségek ismeretében és birtokában - a tudományos eredmények által megerösitve - szükséges lesz a MAGYAR VÍZIVAD GAZDÁLKODÁSI TERV újrafogalmazására, az új terv legszélesebb körü bevezetése feltételrendszereinek megteremtésére és következetes betartására, betartatására. Ez a paradigmaváltás az egyedüli esélye a vonuló (és fészkelö) vízivad fajok fenntartásának Magyarországon. 


\section{IRODALOMJEGYZÉK}

AEBISCHER, N. J. (1991): Sustainable yields: Gamebirds as a harvestable resource. Gibier Faune Sauvage 8: 335-351.

Anderson, D. R. \& Burnham, K. P. (1976): Population ecology of the Mallard VI. The effect of exploitation on survival. U.S. Fish and Wildlife Service, Sesource Publications 128. 66 p.

Bell, D. V. \& Owen, M. (1990): Shooting disturbence - a review. In Matthews, G. V. T. (1990): Managing Waterfowl Populations. Proc. IWRB Symp. Astrakhan 1989. IWRB Special Publication 12: 159-171.

BÉlANGER, L. \& BÉDARD, J. (1990): Energetic cost of man-induced disturbance to staging Greater Snow Geese. Journal of Wildlife Management 54: 36-41. http://dx.doi.org/10.2307/3808897

BoYD, H. (1957): The use of hand-reared ducks for supplementing wild populations. Wildfowl Trust Annual Report 8: 91-95.

BOYD, H. (1984): Intensive regulation of duck hunting in North America: its purpose and achievements. Occasional Paper 50. Canadian Wildlife Service, Ottawa, 23 p.

Boyd, H., Newell, K. L. \& Smith, G. E. J. (1978): Sport hunting of Gadwall and American Wigeon in Canada and the United States, 1968-76, and its relationship to population changes. Can. Wildl. Service Report Ser. No. 43: 101-109.

Boyd, H., LÉvesque, H. \& DicKson, K. M. (2002): Changes in reported waterfowl hunting activity and kill in Canada and the United States, 1985-1998. Occasional Paper Number 107, Canadian Wildlife Service, $24 \mathrm{p}$.

BRACKHAGE, G. K. (1953): Migration and mortality of ducks hand-reared and wild-trapped at Manitoba. Journal of Wildlife Management 17: 465-477. http://dx.doi.org/10.2307/3797053

Cooch, E. G., Lank, D. B., Rockwell, R. F. \& Cooke, F. (1989): Long-term decline in fecundity in a snow goose population: evidence of for density dependence? Journal of Animal Ecology 58: 711-726. http://dx.doi.org/10.2307/4858

CoOke, F., Bousfield, M. A. \& SAdurA, A. (1981): Mate change and reproductive success in the lesser snow geese. Condor 83: 322-327. http://dx.doi.org/10.2307/1367500

CsÁNYI S. (szerk.) (1996): Vadgazdálkodási Adattár - 1960-1995. Országos Vadgazdálkodási Adattár, Gödöllö. o. sz. n.

CsÁNYi S. (szerk.) (1998): Vadgazdálkodás 1997. Országos és megyei összesitések. Országos Vadgazdálkodási Adattár, Gödöllő. o. sz. n.

CsÁNYi S. (szerk.) (1999): Vadgazdálkodás 1998. Országos és megyei összesitések. Országos Vadgazdálkodási Adattár, Gödöllő. 60 p.

CsÁNYi S. (szerk.) (2000): Vadgazdálkodási Adattár - 1999/2000 vadászati év. Országos Vadgazdálkodási Adattár, Gödöllő. o. sz.n.

CsÁNYI S. (szerk.) (2001): Vadgazdálkodási Adattár - 2000/2001 vadászati év. Országos Vadgazdálkodási Adattár, Gödöllő. o. sz. n.

CsÁNYi S. (szerk.) (2002): Vadgazdálkodási Adattár - 2001/2002 vadászati év. Országos Vadgazdálkodási Adattár, Gödöllő. o. sz. n.

CsáNYi S. (szerk.) (2003): Vadgazdálkodási Adattár - 2002/2003. vadászati év. Országos Vadgazdálkodási Adattár, Gödöllő. 48 p.

CsÁNYi S. (szerk.) (2004): Vadgazdálkodási Adattár - 2003/2004. vadászati év. Országos Vadgazdálkodási Adattár, Gödöllö. 62 p.

CsÁNYI S. (szerk.)(2005): Vadgazdálkodási Adattár - 2004/2005. vadászati év. Országos Vadgazdálkodási Adattár, Gödöllő. 
CSÁNYi S., LEHOCZKY R. \& SonKoly K. (szerk.) (2006): Vadgazdálkodási Adattár - 2005/2006. vadászati év. Országos Vadgazdálkodási Adattár, Gödöllő. 64 p.

CSÁNYI S., LEHOCZKY R. \& SONKOLY K. (szerk.) (2007): Vadgazdálkodási Adattár - 2006/2007. vadászati év. Országos Vadgazdálkodási Adattár, Gödöllő. 50 p.

CSÁNYi S., LEHOCZKY R. \& SONKOLY K. (szerk.) (2008): Vadgazdálkodási Adattár - 2007/2008. vadászati év. Országos Vadgazdálkodási Adattár, Gödöllö. 64 p.

CsÁnyi, S., LeHOCZKi, R. \& SonKOLY, K. (szerk.) (2009): Vadgazdálkodási Adattár - 2008/2009. vadászati év. Országos Vadgazdálkodási Adattár, Gödöllő, 56 p.

CSÁNYi S., LEHOCZKY R. \& SONKOLY K. (szerk.) (2010): Vadgazdálkodási Adattár - 2009/2010. vadászati év. Országos Vadgazdálkodási Adattár, Gödöllő. 56 p.

CsÁNyi S., LEHOCZKY R. \& SONKOly K. (szerk.) (2012a): Vadgazdálkodási Adattár 2010/2011. vadászati év. Országos Vadgazdálkodási Adattár, Gödöllő. 52 p.

CSÁNYI S., SONKOLY K. \& LEHOCZKY R. (szerk.) (2012b): Vadgazdálkodási Adattár 2011/2012. vadászati év. Országos Vadgazdálkodási Adattár, Gödöllő. 52 p.

Csányi S., Tóth K. \& Schally G. (szerk.) (2013): Vadgazdálkodási Adattár - 2012/2013. vadászati év. Országos Vadgazdálkodási Adattár, Gödöllö. 52 p.

Csányi S., TóTh K., KovÁcs I. \& Schally G. (szerk.) (2014): Vadgazdálkodási Adattár 2013/2014. vadászati év. Országos Vadgazdálkodási Adattár, Gödöllő. 48 p.

Csányi S., Kovács I., CsókÁs A., Putz K. \& Schally G. (szerk.) (2015): Vadgazdálkodási Adattár - 2014/2015. vadászati év. Országos Vadgazdálkodási Adattár, Gödöllő. 36 p.

CsánYi S., KovÁcs I., CsóKÁs A., Putz K. \& Schally G. (szerk.) (2016): Vadgazdálkodási Adattár - 2015/2016. vadászati év. Országos Vadgazdálkodási Adattár, Gödöllő, 48 p.

EBbinge, B. S. (1991): The impact of hunting on mortality rates and spatial distribution of geese wintering in the Western Palearctic. Ardea 79: 197-210.

Ebbinge, B. S. (1992): Population Limitation in Arctic-breeding Geese. Rijksuniversiteit Groningen, Proefschrift, $200 \mathrm{p}$.

FARAGó, S. (1982a): Vízivad vadászat Magyarországon 1970-1980. Nimród Fórum 1982. nov.: 14-22.

FARAGÓ, S. (1988): Adatok a vadászható récefajok terítékarányaihoz Magyarországon. Puszta 3 (12): 73-90.

FARAGÓ, S. (1991a): A vízivad és vadászata. Venatus, Budapest, 87 pp.

FARAGÓ, S. (1991b): Bestandsverhältnisse bei der Saatgans (Anser fabalis) und Dynamik ihres Zuges auf der ungarischen Seite des Neusiedler Sees. BFB-Bericht 77: 59-76.

FARAGÓ, S. (1993a): Bestandsverhältnisse bei der Blässgans (Anser albifrons) und Dynamik ihres Durchzuges auf der ungarischen Seite des Neusiedler Sees. BFB-Bericht 79: 105116.

FARAGÓ, S. (1995): Geese in Hungary 1986-1991. Numbers, Migration and Hunting Bags. Slimbridge, UK. IWRB Publication 36. 97 + IX pp.

FARAGÓ, S. (1996): A Magyar Vadlúd Adatbázis 1984-1995: Egy tartamos monitoring - Data base of geese in Hungary 1984-1995: A long-term monitoring. Magyar Vizivad Közlemények 2: 3-168.

FARAgó, S. (1997a): The Hungarian Waterfowl Management Plan. Gibier Faune Sauvage, Game and Wildlife 13: 1023-1038.

FARAGó, S. (1997b): Élőhelyfejlesztés az apróvad-gazdálkodásban. A fenntartható apróvadgazdálkodás környezeti alapjai. Mezőgazda Kiadó, Budapest, 356 p.

FARAGó, S. (1998a): A vadlúd monitoring eredményei az 1996/1997-es idényben. Magyarországon. Magyar Vízivad Közlemények 4: 17-59

FARAGó, S. (1998b): A Magyar Vízivad Monitoring eredményei az 1996/1997-es idényben. Magyar Vizivad Közlemények 4: 61-263. 
FARAGÓ, S. (1998c): A Magyar Vízivad Információs Rendszer. Magyar Vízivad Közlemények 4: 3-16.

FARAGÓ, S. (1999a): A vadlúd monitoring eredményei az 1997/1998-as idényben Magyarországon. Magyar Vizivad Közlemények 5: 3-62.

FARAGÓ, S. (1999b): A Magyar Vízivad Monitoring eredményei az 1997/1998-as idényben. Magyar Vizivad Közlemények 5: 63-328.

FARAGÓ, S. (szerk.)(1999c): Az apróvad-gazdálkodás stratégiai terve Magyarországon. Vadászévkönyv 2000: 112-146.

FARAGÓ, S. (2000a): A vadászható vízivad fajok magyarországi vonulása, jelölt madarak megkerülése alapján. Magyar Vízivad Közlemények 6: 337-375.

FARAGÓ, S. (2001a): A Vadlúd Monitoring eredményei az 1998/1999-es idényben Magyarországon. Magyar Vizivad Közlemények 7: 3-40.

FARAGÓ, S. (2001b): A Magyar Vízivad Monitoring eredményei az 1998/1999-es idényben. Magyar Vizivad Közlemények 7: 41-212.

FARAGÓ, S. (2001c): Spatial-temporal pattern of goose bags in Hungary - effect of shooting on dynamics of huntable goose species. In: PATTERSON, I. (szerk): Proceedings of the $6^{\text {th }}$ Annual Meeting of the Goose Specialist Group of Wetlands International. Roosta, Estonia. Wetlands International Goose Specialist Group Bulletin 9: 20-21.

FARAGÓ, S. (2001d): Trends in the breeding and staging population of the Grey-lag Goose (Anser anser) in Hungary. In: PATTERSON, I. (szekr.): Proceedings of the $6^{\text {th }}$ Annual Meeting of the Goose Specialist Group of Wetlands International. Roosta, Estonia. Wetlands International Goose Specialist Group Bulletin 9: 21-22.

FARAGÓ, S. (2002a): A Vadlúd Monitoring eredményei az 1999/2000-es idényben Magyarországon. Magyar Vizivad Közlemények 8: 3-43.

FARAGÓ, S. (2002b): A Vadlúd Monitoring eredményei a 2000/2001-es idényben Magyarországon. Magyar Vízivad Közlemények 9: 3-45.

FARAGÓ, S. (2002c): A Magyar Vízivad Monitoring eredményei a 2000/2001-es idényben. Magyar Vizivad Közlemények 9: 47-249.

FARAGÓ, S. (2002d): Vadászati állattan. Mezőgazda Kiadó, Budapest, 496 p.

FARAGÓ, S. (2004a): The White-fronted Goose - Anser albifrons (SCOPOLI, 1769) - in Hungary. Abstracts of $8^{\text {th }}$ Annual Meeting of the Goose Specialist Group of Wetlands International, Odessa, 5-10. March 2004, Ukraine: 33-35.

FARAGó, S. (2005a): A Vadlúd Monitoring eredményei a 2002/2003-as idényben Magyarországon. Magyar Vizivad Közlemények 12: 3-42.

FARAGÓ, S. (2005b): A Magyar Vízivad Monitoring eredményei a 2002/2003-as idényben. Magyar Vízivad Közlemények 12: 43-224.

FARAGÓ, S. (2005c): Hunting utilisation of geese in Hungary. Abstracts of GOOSE 2005. $9^{\text {th }}$ Annual Meeting of Goose Specalist Group of Wetlands International, 5-9. November 2005. Sopron, Hungary.

FARAGÓ, S. (2006a): A Vadlúd Monitoring eredményei a 2003/2004-es idényben Magyarországon. Magyar Vízivad Közlemények 13: 3-39.

FARAGó, S. (2006b): A Magyar Vízivad Monitoring eredményei a 2003/2004-es idényben. Magyar Vizivad Közlemények 13: 41-214.

FARAGó, S. (2007a): A Vadlúd Monitoring eredményei a 2004/2005-ös idényben Magyarországon. Magyar Vízivad Közlemények 14: 3-40.

FARAGÓ, S. (2007b): A Magyar Vízivad Monitoring eredményei a 2004/2005-ös idényben. Magyar Vízivad Közlemények 14: 41-209.

FARAGÓ, S. (2007c): A Vadlúd Monitoring eredményei a 2005/2006-os idényben Magyarországon. Magyar Vízivad Közlemények 15: 3-45. 
FARAGÓ, S. (2007d): A Magyar Vízivad Monitoring eredményei a 2005/2006-os idényben. Magyar Vizivad Közlemények 15: 47-220.

FARAGó, S. (2008a): A Vadlúd Monitoring eredményei a 2006/2007-es idényben Magyarországon. Magyar Vizivad Közlemények 17: 3-42.

FARAGÓ, S. (2008b): A Magyar Vízivad Monitoring eredményei a 2006/2007-es idényben. Magyar Vízivad Közlemények 17: 43-214.

FARAGÓ, S. (2009): A történelmi Magyarország vadászati statisztikái 1879-1913. Nyugatmagyarországi Egyetem Kiadó, Sopron. 455 p.

FARAGó, S. (2010a): A Vadlúd Monitoring eredményei a 2007/2008-as idényben Magyarországon. Magyar Vízivad Közlemények 18-19: 3-42.

FARAGÓ, S. (2010b): A Magyar Vízivad Monitoring eredményei a 2007/2008-as idényben. Magyar Vizivad Közlemények 18-19: 43-204.

FARAGÓ, S. (2010c): A Vadlúd Monitoring eredményei a 2008/2009-es idényben Magyarországon. Magyar Vízivad Közlemények 18-19: 221-258.

FARAGó, S. (2010d): A Magyar Vízivad Monitoring eredményei a 2008/2009-es idényben. Magyar Vizivad Közlemények 18-19: 259-420.

FARAGÓ, S. (2011a): A Vadlúd Monitoring eredményei a 2009/2010-es idényben Magyarországon. Magyar Vízivad Közlemények 20-21: 3-41.

FARAGÓ, S. (2011b): A Magyar Vízivad Monitoring eredményei a 2009/2010-es idényben. Magyar Vizivad Közlemények 20-21: 43-200.

FARAGÓ, S. (2011c): A Vadlúd Monitoring eredményei a 2010/2011-es idényben Magyarországon. Magyar Vízivad Közlemények 20-21: 201-249.

FARAGÓ, S. (2011d): A Magyar Vízivad Monitoring eredményei a 2010/2011-es idényben. Magyar Vízivad Közlemények 20-21: 251-486.

FARAGÓ, S. (2011e): Habitat selection of migratory waterfowl species in Hungary. Aquila 118: 7-26.

FARAGó, S.. (2012a): A Vadlúd Monitoring eredményei az 2011/2012-es idényben Magyarországon. Magyar Vízivad Közlemények 22: 1-50.

FARAGó, S. (2012b): A Magyar Vízivad Monitoring eredményei a 2011/2012-es idényben. Magyar Vizivad Közlemények 22: 51-284.

FARAGÓ, S.. (2014a): A Vadlúd Monitoring eredményei az 2012/2013-as idényben Magyarországon. Magyar Vizivad Közlemények 24: 3-49.

FARAGÓ, S. (2014b): A Magyar Vízivad Monitoring eredményei a 2012/2013-as idényben. Magyar Vízivad Közlemények 24: 51-281.

FARAGÓ, S.. (2015a): A Vadlúd Monitoring eredményei az 2013/2014-es idényben Magyarországon. Magyar Vizivad Közlemények 25: 1-54. http://dx.doi.org/10.17242/MVvK_Monitoring/25-1

FARAGÓ, S. (2015b): A Magyar Vízivad Monitoring eredményei a 2013/2014-es idényben. Magyar Vizivad Közlemények 25: 55-288. http://dx.doi.org/10.17242/MVvK_Monitoring/25-2

FARAGÓ, S.. (2016a): A Vadlúd Monitoring eredményei az 2014/2015-ös idényben Magyarországon. Magyar Vizivad Közlemények 27: 3-53. http://dx.doi.org/10.17242/MVvK_27.01

FARAGó, S. (2016b): A Magyar Vízivad Monitoring eredményei a 2014/2015-ös idényben. Magyar Vizivad Közlemények 27: 55-281. http://dx.doi.org/10.17242/MVvK_27.02

FARAGÓ, S.. (2017a): A Vadlúd Monitoring eredményei az 2015/2016-os idényben Magyarországon. Magyar Vizivad Közlemények 29: 3-51. http://dx.doi.org/10.17242/MVvK_29.01 
FARAGÓ, S. (2017b): A Magyar Vízivad Monitoring eredményei a 2015/2016-os idényben. Magyar Vizivad Közlemények 29: 53-296. http://dx.doi.org/10.17242/MVvK_29.02

FARAGÓ, S., CSÁNYI, S \& LEHOCZKI, R. (2001): A vízivad teríték Magyarországon az 1998/1999es vadászidényben. Magyar Vízivad Közlemények 7: 213-293.

FARAgó, S., CSÁNYI, S \& LEHOCZKI, R. (2002a): A vízivad teríték Magyarországon az 1999/2000-es vadászidényben. Magyar Vizivad Közlemények 8: 256-325.

FARAGÓ, S., CsÁNYI, S \& LEHOCZKI, R. (2002b): A vízivad teríték Magyarországon az 2000/2001-es vadászidényben. Magyar Vizivad Közlemények 9: 251-322.

FARAGÓ, S., CSÁNYI, S \& LEHOCZKI, R. (2003): A vízivad teríték Magyarországon az 2001/2002es vadászidényben. Magyar Vizivad Közlemények 11: 253-342.

FARAGÓ, S. \& GoszTONYI, L. (2002): A Magyar Vízivad Monitoring eredményei az 1999/2000es idényben. Magyar Vizivad Közlemények 8: 45-256.

FARAGÓ, S. \& GoszTONYI, L. (2003a): A Vadlúd Monitoring eredményei a 2001/2002-es idényben Magyarországon. Magyar Vízivad Közlemények 11: 3-50.

FARAGó, S. \& GoszTONYI, L. (2003b): A Magyar Vízivad Monitoring eredményei a 2001/2002es idényben. Magyar Vízivad Közlemények 11: 51-252.

FARAGÓ, S. \& GoszTONYI, L. (2009): Population trend, phenology and dispersion of common waterfowl species in Hungary based on a ten year long time series of the Hungarian Waterfowl Monitoring. Acta Silvatica et Lignaria Hungarica 5: 83-107.

FARAGÓ, S. \& JÁNOSKA, F. (1996a): A Szeptemberi Nemzetközi Nyári Lúd (Anser anser) Számlálás magyarországi eredményei 1989-1996. Magyar Vizivad Közlemények 2: 213222.

FARAGó, S. \& JÁnOSKA, F. (1996b): A Vadlúd Monitoring Eredményei az 1995/1996-os idényben Magyarországon. Magyar Vizivad Közlemények 2: 169-211

FARAGÓ, S. \& NÁHLIK, A. (1997): A vadállomány szabályozása. A fenntartható vadgazdálkodás populációökológiai alapjai. Mezőgazda Kiadó, Budapest, 315 p.

FARAGÓ, S. \& RITTER, D. (1998): A vízivad teríték Magyarországon 1996-ban. Magyar Vízivad Közlemények 4: 265-365

FARAGÓ, S. \& RITTER, D. (1999): A vízivad teríték Magyarországon 1997-ben. Magyar Vizivad Közlemények 5: 329-418.

FIgLeY, W. K. \& VAN DRUfF, L. W. (1982): The ecology of urban Mallard. Wildlife Monographs 81. $40 \mathrm{p}$.

FoG, J. (1965): The Mallards from the estate of Kongsdal. Danish Review of Game Biology 4 (3): 65-94.

FOG, J. (1968): Krikandens (Anas crecca) spredning under fourageringstogter fra en resteplads (Albriebugten vildtreservat, Fanø). Dansk Orn. For. Tidsskr. 62: 32-36.

FOG, J. (1971): Survival and exploitation of Mallard (Anas platyrhynchos) released for shooting. Danish Review of Game Biology 6 (4): 1-12.

FÜLEKY, Cs. (2000): Egyezmény a vadon élő vándorló állatfajok védelméről. A Bonni Egyezmény, valamint csatlakozó egyezményei. In: FARAGÓ, S. (szerk.): Gerinces állatfajok védelme. Sopron, Nyugat-Magyarországi Egyetem, Erdőmérnöki Kar pp. 4148.

GALlÉ, L. (2003): A Tisza hullámtere, mint ökológiai folyosó. In TEPLÁN, I. (szerk.): A Tisza vízrendszere. II. kötet. Magyarország az ezredfordulón. Stratégiai tanulmányok a Magyar Tudományos Akadémián. IV. program: A területfejlesztési program tudományos alapozása. 4. alprogram: A Tisza, MTA Társadalomkutató Központ, Budapest, pp. 65-90.

GEIS, A., D. (1963): Role of hunting regulations in migratory bird management. Transaction of North American Wildlife Conference 28: 164-172. 
HEPBURN, J. (1984): Wildgänse. DJV-Nachrichten 1: 11-17.

HILl, D. (1983): Compensatory Mortality in the Mallard. The Game Conservancy Annual Review 14: 87-92.

HILL, D. A. (1984): Population regulation in the Mallard (Anas platyrhynchos). Journal of Animal Ecology 53: 191-202. http://dx.doi.org/10.2307/4351

Hopper, R. M., GeIS, A. D., GRIEB, J. R. \& Nelson, L. (1975): Experimental Duck Hunting Seasons, San Louis Valley, Colorado 1963-70. Wildlife Monographs 46.

KalChreuter, H. (1984): Die Sache mit der Jagd. (Neuausgabe). München, 303 p.

KALChreUter, H. (1987): Wasserwild im Visier. Jagd und Schutz von Wasservögeln. BLV Verlagsgesellschaft, München, Wien, Zürich, 286 p.

KAlChreUter, H. (1994): Jäger und Wildtier. Auswirkungen der Jagd auf Tierpopulationen. Verlag Dieter Hoffmann, Mainz, 299 p.

LANDRY, PH. (1990a): Bag statistics: a review of methods and problems. In: MATTHEWs, G. V. T. (szerk.): Managing Waterfowl Populations. Proceedings of IWRB Symposium, Astrakhan 1989. IWRB Special Publications 12. pp. 105-112.

LANDRY, PH. (1990b): Hunting harvest of waterfowl in the Western Palearctic and Africa. In: Matthews, G. V. T. (szerk.): Managing Waterfowl Populations. Proceedings of IWRB Symp., Astrakhan 1989. IWRB Special Publications 12: 120-121.

LANDRY, PH. \& Migot, P. (2000): Enquête nationale sur les tableaux dr chasse à tir. Saison 1998/1999. Faune Sauvage, Cahiers Techniques, 251. Août/septembre 2000, 215 p.

LEHOCZKI, R. \& CSÁNYI, S. (2006): A vízivadfajok terítéke a 2005/2006. vadászati évben. pp. 56-61. In: CsÁNYi, S., LeHOCZKI, R. \& SONKOly, K. (szerk.): Vadgazdálkodási Adattár 2005/2006. vadászati év. Országos Vadgazdálkodási Adattár, Gödöllő, 64p.

LEHOCZKI, R. \& CSÁNYI, S. (2007): A vízivadfajok terítéke a 2006/2007. vadászati évben. pp. 45-50. In: CsÁnYi, S., LeHOCZKi, R. \& SonKOly, K. (szerk.): Vadgazdálkodási Adattár 2006/2007. vadászati év. Országos Vadgazdálkodási Adattár, Gödöllő, 50p.

LEHOCZKI, R. \& CSÁNYI, S. (2008): A vízivadfajok terítéke a 2007/2008. vadászati évben. pp. 56-61. In: CsÁNYI, S., LEHOCZKI, R. \& SONKOLY, K. (szerk.): Vadgazdálkodási Adattár 2007/2008. vadászati év. Országos Vadgazdálkodási Adattár, Gödöllő, 64p.

LEHOCZKI, R. \& CSÁNYI, S. (2009): A vízivadfajok terítéke a 2008/2009. vadászati évben. pp. 49-54. In: CsÁNYI, S., LEHOCZKI, R. \& SONKOlY, K. (szerk.): Vadgazdálkodási Adattár 2008/2009. vadászati év. Országos Vadgazdálkodási Adattár, Gödöllö, 56p.

LEHOCZKI, R. \& CSÁNYI, S. (2010): A vízivadfajok terítéke a 2009/2010. vadászati évben. pp. 52-56. In: CsÁnYI, S., LeHOCZKI, R. \& SONKOly, K. (szerk.): Vadgazdálkodási Adattár 2009/2010. vadászati év. Országos Vadgazdálkodási Adattár, Gödöllő, 56p.

LEHOCZKI, R. \& CSÁNYI, S. (2012a): A vízivad terítéke a 2010/2011. vadászati évben. pp. 49-52. In: CsÁnyi, S., LehoczKi, R. \& Sonkoly, K. (szerk.): Vadgazdálkodási Adattár 2010/2011. vadászati év. Országos Vadgazdálkodási Adattár, Gödöllő, 52p.

LEHOCZKI, R. \& CSÁNYI, S. (2012b): A vízivad terítéke a 2011/2012. vadászati évben. pp. 47-51. In: CsÁnyi, S., Lehoczki, R. \& Sonkoly, K. (szerk.): Vadgazdálkodási Adattár 2011/2012. vadászati év. Országos Vadgazdálkodási Adattár, Gödöllő, 52p.

Macinnes, C. D., Davis, R. A., Jones, R. N., LiefF, B. C. \& PakulaK, A. J. (1974): Reproductive efficiency of McConnell river Small Canada Geese. Journal of Wildlife Management 38 (4): 686-707. http://dx.doi.org/10.2307/3800036

MADSEN, J. \& FOX, A. (1995): Impacts of hunting disturbance on waterbirds - a review. Wildlife Biology 1 (4): 193-207.

Madsen, J., Frikke, J., Kristensen, J. B., Bøgebjerg, E. \& Hounisen, J. P. (1992): Forsøgsreservat Nibe Bredning: Baggrundsundersøgelser efteråret 1985 til foråret 1989. Danmarks Miljøundersøgelser, Faglig Rapport fra DMU No. 46.50 pp. 
Madsen, J., Hounisen, J. P., Bøgebjerg, E. \& Jørgensen, H. E. (1995): Udviklingen i de rastende bestande af vandfugle i forsøgsreservaterne 1985-1993. Danmarks Miljøundersøgelser, Faglig Rapport fra DMU No. 132. 40 pp.

Meltofte, H. (1982): Jagtlige forstyllerser af svømme-og vade-fugle. Dansk Orn. Foren. Tidsskr. 76: 21-35.

MooiJ, J. H. (2005): Protection and use of waterbirds in the European Union. Beiträge zur Jagdund Wildforschung 30: 49-76.

Nagy, E. (1971): A fácán és a fogoly intenziv tenyésztése. Függelék: A vadréce tenyésztése. Mezőgazdasági Kiadó, Budapest, p. 231.

NAGY, E. (1989): A vadréce intenzív tenyésztésének eredményei és tapasztalatai. Vadbiológia 3: 23-37.

NAGY, E. \& PuskÁs, I. (1978): A vadrécetenyésztés fejlesztésének lehetőségei. Nimród Fórum. 1978. szeptember: $3-4$.

Nechay, G. (2000): Egyezmény az európai vadon élö növények, állatok és természetes élőhelyeik védelmére - Berni Egyezmény. In: FARAGÓ, S. (szerk.): Gerinces állatfajok védelme. Sopron, Nyugat-Magyarországi Egyetem, Erdőmérnöki Kar pp. 49-54.

NÉMETH, F. (szerk.) (1995): Nemzeti ökológiai hálózat. Javaslat a környezet-és természetbarát területhasznositásra. IUCN Természetvédelmi Világszövetség. 88 p.

Nichols, J. D. \& Hines, J. E. (1983): The relationship between harvest and survival rates of Mallards: a straight-forward approach with partitioned data sets. Journal of Wildlife Management 47 (2): 334-348. http://dx.doi.org/10.2307/3808506

NowAK, E. (1976): On the 'Hunting Pressure' on Waterfowl in Europe. In: SMART, M. (szerk.): Proceedings of International Conference on the Conservation of Wetlands and Waterfowl. Heiligenhafen, Federal Republic of Germany, 2-6. December 1974. IWRB, Slimbridge (Glos.), England. pp. 406-422.

OgILVIE, M. A. (1978): Wild Geese. Berkhamsetd, Poyser, 350 p.

OGiLvie, M. A. (1982): The status of the Pink-footed Goose Anser brachyrhyncus. Aquila 89: 127-131.

OgILvie, M. A. \& CoOK, W. A. (1972): British recoveries of Mallard ringed at Borough Fen Decoy, Northhamptonshire. Wildfowl 23: 103-110.

Owen, M. (1982): Population dynamics of Svalbard Barnacle Geese. Aquila 89: 229-247.

OWEN, M. (1984): Dynamics and age structure of an increasing goose population - the Svalbard Barnacle Goose. Norsk Polarinst. Skr. 181: 37-47.

OWEn, M., Black, J. M. \& LiBER, H. (1988): Pair bond duration and timing of its formation in Barnacle Geese (Branta leucopsis). In: Weller, M. W. (szerk.): Waterfowl in Winter. University of Minnesota Press, Minneapolis. pp. 257-269.

OWEN, M. \& BLACK, J. M. (1990): The importance of migration mortality in non-passerine birds. In: Perrins, C. M., Lebreton, J. D. \& Hirons, G. J. M. (szerk.): Bird population studies: Relevance to conservation and management. Oxford University Press, Oxford. pp.360372.

Owen, M., Wells, R. L. \& Black, J. M. (1992): Energy budgets of wintering Barnacle Geese: the effect of declining food resources. Ornis Scandinavica 23: 451-458. http://dx.doi.org/10.2307/3676676

OwEN, M. \& WiLliaMS, G. (1976): Winter distribution and habitat requirements of Wigeon in Britain. Wildfowl 27: 83-90.

PARrish, J. M. \& HunTER, B. F. (1969: Waterfowl Botulism in the Southern San Joaquin Valley, 1967-68. Californian Fish and Game 55: 265-272. 
PATTERSON, J. H. (1979): Can ducks be managed by regulation? Experiences in Canada. Transaction of 44th North American Wildlife and Nature Resource Conference. pp. 114126.

Pirkola, M. K. \& Kalanainen, P. (1984): The status, habitats and productivity of breeding populations of Bean Goose, Anser f. fabalis, in Finland. Wiltrevy 13 (1): 9-48.

Prevett, J. P. \& MacInNes, C. D. (1980): Family and other social groups in snow geese. Wildlife Monographs No. 71. 46 p.

Robertson, P. (1991): Wise use and conservation. Gibier Faune Sauvage 8: 379-388.

Rodics, K. (2000): A Washingtoni Egyezmény. In: FARAGÓ, S. (szerk.): Gerinces állatfajok védelme. Sopron, Nyugat-Magyarországi Egyetem, Erdőmérnöki Kar pp. 55-70.

Rogers, J. P., Nichols, J. D., Martin, F. W., Kimball, C. F. \& Pospahala, R. S. (1979): An examination on harvest and survival rates of ducks in relation to hunting. Transaction of $44^{\text {th }}$ North American Wildlife and Nature Resource Conference. pp. 114-126.

Rose, P. M. \& ScotT, D. A. (1994): Waterfowl population estimates. IWRB Special Publications 29. $102 \mathrm{p}$.

SCHIFFERLI, L. (1982): Waterfowl counts and duck wing analysis in Switzerland. In: SCOTT, D. A. \& SMART, M. (szerk.): Proceedings of Second Technical Meeting on Western Palearctic Migratory Bird Management, 1979: 121-136.

TAMISIER, A. (1985): Hunting as a key environmental parameter for the Western Palearctic duck populations. Wildfowl 36: 95-103.

TAPPER, S. (1992): Game Heritage. An Ecological Review from Shooting and Gamekeeping Records. The Game Conservancy Ltd., Fordingbridge, UK, 140 p.

Trost, R. E. \& Malecki, R. A. (1985): Population trends in Atlantic Flyway Canada geese: implications for management. Wildlife Society Bulletin 13: 502-508.

TVEIT, G. (1984): Autumn migration, wintering areas and survival of Bean Geese, Anser fabalis, marked on the moulting grounds in Finnmark, north Norway. Viltrevy 13 (1): 73-81. 


\title{
EFFECT OF SHOOTING ON WATERFOWL POPULATIONS IN HUNGARY
}

\author{
Faragó Sándor \\ SUMMARY
}

The Author is presenting the formation of legal regulations concerning waterfowl shooting in Hungary, with especial regard to the changes of the past two decades. He is analysing the current legal conditions, which influences the utilization of waterfowl. These are in compliance with the law and order of the EU and the international agreements ratified by Hungary. To this analysis, the Author is employing the population size data of Wild Goose and Wild Duck, collected both within the framework of the HUNGARIAN WATERFOWL MONITORING (Map 1) and the Hungarian ecoregions (Map 2), and the hunting statistics data recorded in the HuNGARIAN GAME MANAGEMENT DATABASE. In relation with Geese there have been statements since 1992 and with Ducks since 1996.

The bag record of Goose species did not take place on species level at the beginning (Fig. 2-3), statistics of species level (Fig. 4) have been disposable only since 1992. The examination is introducing the bag-trends of Bean Goose and Greater White-fronted Goose in relation with the past quarter of a century on a regional level, and the ratio of bags of these two species among regions (Fig. 6-7). We also present the species-dominance change of the bag within ecoregions in the bag (Fig. 8). Since 2012, besides Bean Goose and Greater White-fronted Goose, Greylag Goose has been huntable species as well.

We can declare that the protection and hunting of Great White-fronted Goose and Graylag Goose has been going on in the spirit of wise use. In the case of Bean Goose the hunting bag of official statistics reaches the estimated amount, which is impossible and groundless. According to estimations the national bag should only be maximum of 300-350 specimens!

The bag dynamics between 1884 and 2015 are available in the case of Ducks and Eurasian Coot species (Fig. 9). The trends of the past 20 years according to species level bags are also disposable (Fig. 10). On the basis of all these, the ratio-dynamics of bag - among regions - for five huntable duck species and the Eurasian Coot can be shown: Mallard (Fig. 11), Eurasian Teal (Fig. 12), Garganey (Fig. 13), Common Pochard (Fig. 14), Common Goldeneye (Fig. 15) and Eurasian Coot (Fig. 16). The ratio change-dynamics of hunted ducks and Eurasian Coot between one another is also given for the two decades.

The Author has examined regression connections between population number and bag size both in the case of geese (Fig. 18-22) and ducks and Eurasian Coot (Fig. 24-29).

The decrease of the population of Eurasian Teal, Garganey, Common Pochard and Common Goldeneye has led to their protected status. After the protection declaration of the latter four species, with the exception of the Mallard and besides the three goose species, it is only the Eurasian Coot that is huntable in Hungary. Though, concerning bag size, its hunting role (3-4 \%) is eclipsed by the Mallard.

With knowing the five currently huntable waterfowl species, we can say that utilization refers to the most common waterfowl species (Table 2) in Hungary. Hunting season is focusing on optimal periods (Fig. 33) in terms of phenology, and this means that our regulations are perfectly in compliance with international expectations and wise use. We have to highlight Bean Goose since its hunting should be suspended owing to a dramatic decrease in its population recently.

The Author is also showing the waterfowl all-year round close season areas, and its principle of 30-50 km wide protected zones, introduced in 1993 and also the suggestion of its widening (Map 3-7). 


\section{1. melléklett: A vetési lúd terítéke Magyarországon, 1994-2016}

Appendix 1: Bag of Bean Goose in Hungary, 1994-2016

\begin{tabular}{|c|c|c|c|c|c|c|c|c|c|c|c|c|c|c|c|c|c|c|c|c|c|c|}
\hline $\begin{array}{l}\text { Megye, régió } \\
\text { County, region }\end{array}$ & 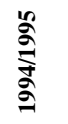 & 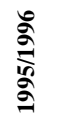 & ڤે & $\stackrel{\infty}{\stackrel{2}{\sigma}}$ & $\begin{array}{l}\stackrel{\partial}{\partial} \\
\stackrel{\partial}{\sigma}\end{array}$ & 高 & 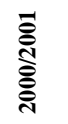 & 芯 & ڤ్心ิ & 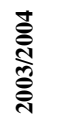 & 言 & 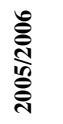 & 突 & 言 & 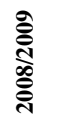 & 옳 & 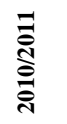 & 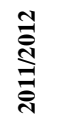 & 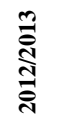 & 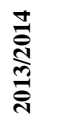 & 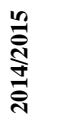 & 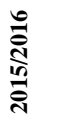 \\
\hline Györ-Moson-Sopron & 932 & 1492 & 1021 & 1113 & 757 & 476 & 387 & 517 & 365 & 351 & 313 & 250 & 333 & 488 & 618 & 775 & 432 & 485 & 396 & 217 & 194 & 121 \\
\hline Komárom-Esztergom & 279 & 270 & 250 & 272 & 412 & 233 & 231 & 135 & 152 & 157 & 217 & 82 & 162 & 144 & 111 & 198 & 222 & 431 & 231 & 298 & 89 & 53 \\
\hline Vas & 46 & 22 & 40 & 35 & 35 & 37 & 29 & 4 & 14 & 7 & 0 & 1 & 0 & 11 & 18 & 13 & 9 & 11 & 20 & 7 & 22 & 11 \\
\hline Veszprém & 111 & 85 & 116 & 119 & 90 & 110 & 93 & 75 & 112 & 58 & 34 & 50 & 28 & 48 & 59 & 56 & 44 & 65 & 44 & 19 & 17 & 14 \\
\hline Fejér & 979 & 615 & 615 & 566 & 723 & 1590 & 1464 & 856 & 934 & 1096 & 964 & 141 & 1167 & 1682 & 1816 & 1229 & 1068 & 1523 & 735 & 660 & 271 & 484 \\
\hline $\begin{array}{l}\text { Észak-Dunántúl } \\
\text { Northern } \\
\text { Transdanubia }\end{array}$ & 2347 & 2484 & 2042 & 2105 & 2017 & 2446 & 2204 & 1587 & 1577 & 1669 & 1528 & 524 & 1690 & 2373 & 2622 & 2271 & 1775 & 2515 & 1426 & 1201 & 593 & 683 \\
\hline Zala & 102 & 144 & 201 & 194 & 228 & 281 & 234 & 222 & 333 & 110 & 107 & 59 & 34 & 65 & 53 & 56 & 57 & 41 & 32 & 15 & 16 & 9 \\
\hline Somogy & 237 & 174 & 222 & 174 & 193 & 194 & 98 & 111 & 155 & 240 & 121 & 89 & 91 & 140 & 214 & 181 & 139 & 138 & 78 & 38 & 12 & 19 \\
\hline Tolna & 949 & 560 & 543 & 249 & 585 & 617 & 182 & 316 & 100 & 243 & 145 & 102 & 57 & 285 & 24 & 47 & 89 & 82 & 70 & 16 & 46 & 46 \\
\hline Baranya & 283 & 320 & 709 & 171 & 517 & 225 & 138 & 122 & 70 & 157 & 165 & 72 & 16 & 25 & 27 & 19 & 8 & 5 & 11 & 12 & 13 & 5 \\
\hline $\begin{array}{l}\text { Dél-Dunántúl } \\
\text { Southern } \\
\text { Transdanubia }\end{array}$ & 1571 & 1198 & 1675 & 788 & 1523 & 1317 & 652 & 771 & 658 & 750 & 538 & 322 & 198 & 515 & 318 & 303 & 293 & 266 & 191 & 81 & 87 & 79 \\
\hline Nógrád & 0 & 0 & 2 & 0 & 0 & 0 & 0 & 0 & 0 & 1 & 0 & 0 & 0 & 0 & 0 & 0 & 0 & 1 & 0 & 0 & 0 & 0 \\
\hline Heves & 132 & 199 & 88 & 67 & 18 & 68 & 162 & 52 & 56 & 89 & 22 & 17 & 16 & 10 & 23 & 5 & 14 & 64 & 16 & 8 & 2 & 19 \\
\hline Borsod-Abaúj-Zemplén & 86 & 10 & 28 & 28 & 7 & 5 & 36 & 13 & 17 & 22 & 17 & 32 & 56 & 3 & 0 & 5 & 58 & 41 & 34 & 21 & 2 & 20 \\
\hline $\begin{array}{l}\text { Észak-Magyarország } \\
\text { Northern Hungary }\end{array}$ & 218 & 209 & 118 & 95 & 25 & 73 & 198 & 65 & 73 & 112 & 39 & 49 & 72 & 13 & 23 & 10 & 72 & 106 & 50 & 29 & 4 & 39 \\
\hline Pest & 23 & 26 & 33 & 4 & 27 & 32 & 30 & 25 & 19 & 21 & 33 & 13 & 36 & 59 & 20 & 142 & 97 & 33 & 33 & 72 & 59 & 43 \\
\hline Bács-Kiskun & 1399 & 1116 & 1269 & 976 & 1021 & 1530 & 710 & 263 & 163 & 327 & 343 & 314 & 188 & 166 & 166 & 168 & 364 & 186 & 203 & 133 & 168 & 91 \\
\hline $\begin{array}{l}\text { Duna-Tisza köze } \\
\text { Danube-Tisza } \\
\text { Interfluve }\end{array}$ & 1422 & 1142 & 1302 & 980 & 1048 & 1562 & 740 & 288 & 182 & 348 & 376 & 327 & 224 & 225 & 186 & 310 & 461 & 219 & 236 & 205 & 227 & 134 \\
\hline $\begin{array}{l}\text { Szabolcs-Szatmár- } \\
\text { Bereg }\end{array}$ & 9 & 8 & 3 & 2 & 5 & 2 & 5 & 0 & 0 & 1 & 0 & 0 & 8 & 1 & 0 & 6 & 12 & 75 & 2 & 0 & 12 & 10 \\
\hline Hajdú-Bihar & 238 & 223 & 182 & 217 & 306 & 160 & 209 & 164 & 90 & 73 & 112 & 54 & 105 & 109 & 66 & 99 & 124 & 113 & 95 & 80 & 54 & 92 \\
\hline Jász-Nagykun-Szolnok & 99 & 49 & 95 & 201 & 64 & 159 & 223 & 137 & 105 & 216 & 49 & 101 & 70 & 86 & 56 & 72 & 126 & 70 & 35 & 20 & 62 & 41 \\
\hline Békés & 53 & 68 & 46 & 152 & 106 & 207 & 64 & 87 & 41 & 61 & 95 & 23 & 40 & 92 & 57 & 44 & 130 & 10 & 42 & 87 & 84 & 56 \\
\hline Csongrád & 114 & 53 & 114 & 59 & 57 & 66 & 94 & 53 & 13 & 14 & 19 & 12 & 5 & 19 & 6 & 22 & 70 & 56 & 23 & 21 & 57 & 18 \\
\hline $\begin{array}{l}\text { Tiszántúl } \\
\text { Transtisza }\end{array}$ & 513 & 401 & 440 & 631 & 538 & 594 & 595 & 441 & 249 & 365 & 275 & 190 & 228 & 307 & 185 & 243 & 462 & 324 & 197 & 208 & 269 & 217 \\
\hline $\begin{array}{l}\text { Magyarország } \\
\text { összesen } \\
\text { Hungary total }\end{array}$ & 6071 & 5434 & 5577 & 4599 & 5151 & 5992 & 4389 & 3152 & 2739 & 3244 & 2756 & 1412 & 2412 & 3433 & 3334 & 3137 & 3063 & 3430 & 2100 & 1724 & 1180 & 1152 \\
\hline
\end{tabular}


2. melléklet: A nagy lilik terítéke Magyarországon, 1994-2016

Appendix 2: Bag of Greater White-fronted Goose in Hungary, 1994-2016

\begin{tabular}{|c|c|c|c|c|c|c|c|c|c|c|c|c|c|c|c|c|c|c|c|c|c|c|}
\hline $\begin{array}{l}\text { Megye, régió } \\
\text { County, region }\end{array}$ & 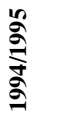 & 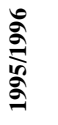 & 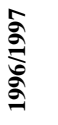 & $\frac{\stackrel{2}{\sigma}}{\stackrel{5}{\sigma}}$ & 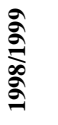 & $\begin{array}{l}\text { ్ㅗㅇ } \\
\text { ڤે }\end{array}$ & 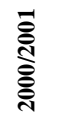 & 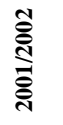 & 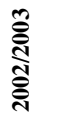 & 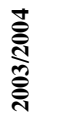 & 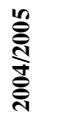 & 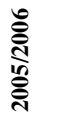 & 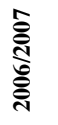 & 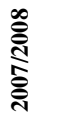 & 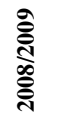 & 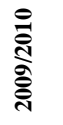 & 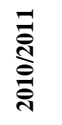 & $\begin{array}{l}\text { 곯 } \\
\text { בิ }\end{array}$ & 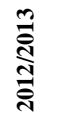 & 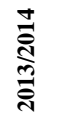 & 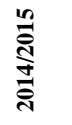 & 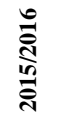 \\
\hline Győr-Moson-Sopron & 6 & 3 & 0 & 22 & 16 & 13 & 34 & 1 & 7 & 58 & 86 & 197 & 144 & 256 & 172 & 465 & 361 & 605 & 659 & 525 & 606 & 604 \\
\hline Komárom-Esztergom & 0 & 0 & 0 & 11 & 15 & 28 & 14 & 0 & 9 & 6 & 20 & 10 & 13 & 27 & 76 & 210 & 134 & 444 & 395 & 506 & 463 & 345 \\
\hline Vas & 0 & 0 & 0 & 5 & 33 & 46 & 0 & 0 & 0 & 0 & 0 & 0 & 5 & 0 & 11 & 8 & 5 & 1 & 2 & 2 & 2 & 2 \\
\hline Veszprém & 2 & 6 & 0 & 5 & 1 & 17 & 0 & 0 & 0 & 6 & 0 & 0 & 0 & 3 & 14 & 20 & 9 & 14 & 19 & 23 & 16 & 14 \\
\hline Fejér & 17 & 7 & 55 & 33 & 51 & 73 & 131 & 201 & 306 & 213 & 436 & 441 & 459 & 652 & 676 & 482 & 693 & 886 & 1425 & 1616 & 1167 & 1430 \\
\hline $\begin{array}{l}\text { Észak-Dunántúl } \\
\text { Northern } \\
\text { Transdanubia } \\
\end{array}$ & 25 & 16 & 55 & 76 & 116 & 177 & 179 & 202 & 322 & 283 & 542 & 648 & 621 & 938 & 949 & 1185 & 1202 & 1950 & 2500 & 2672 & 2254 & 2395 \\
\hline Zala & 0 & 0 & 0 & 0 & 11 & 7 & 15 & 18 & 0 & 102 & 16 & 11 & 3 & 13 & 13 & 11 & 18 & 12 & 21 & 4 & 0 & 0 \\
\hline Somogy & 12 & 35 & 8 & 22 & 15 & 1 & 0 & 0 & 9 & 25 & 29 & 10 & 14 & 44 & 97 & 65 & 68 & 78 & 68 & 30 & 24 & 64 \\
\hline Tolna & 5 & 20 & 0 & 5 & 36 & 103 & 27 & 9 & 10 & 103 & 60 & 46 & 9 & 33 & 30 & 33 & 34 & 30 & 40 & 90 & 40 & 70 \\
\hline Baranya & 55 & 0 & 0 & 0 & 7 & 77 & 6 & 32 & 11 & 8 & 9 & 0 & 0 & 29 & 8 & 0 & 5 & 0 & 68 & 10 & 43 & 0 \\
\hline $\begin{array}{l}\text { Dél-Dunántúl } \\
\text { Southern } \\
\text { Transdanubia } \\
\end{array}$ & 72 & 55 & 8 & 27 & 69 & 188 & 48 & 59 & 30 & 238 & 114 & 67 & 26 & 119 & 148 & 109 & 125 & 120 & 197 & 134 & 107 & 134 \\
\hline Nógrád & 0 & 0 & 21 & 0 & 0 & 0 & 0 & 0 & 0 & 0 & 0 & 0 & 0 & 0 & 0 & 0 & 0 & 0 & 0 & 1 & 0 & 0 \\
\hline Heves & 5 & 5 & 25 & 0 & 5 & 28 & 7 & 54 & 59 & 285 & 164 & 170 & 193 & 182 & 358 & 103 & 222 & 560 & 835 & 1166 & 575 & 1328 \\
\hline Borsod-Abaúj-Zemplén & 17 & 0 & 2 & 1 & 0 & 0 & 23 & 3 & 1 & 0 & 24 & 9 & 30 & 25 & 65 & 44 & 73 & 230 & 43 & 78 & 26 & 87 \\
\hline $\begin{array}{l}\text { Észak-Magyarország } \\
\text { Northern Hungary } \\
\end{array}$ & 22 & 5 & 48 & 1 & 5 & 28 & 30 & 57 & 60 & 285 & 188 & 179 & 223 & 207 & 423 & 147 & 295 & 790 & 878 & 1245 & 601 & 1415 \\
\hline Pest & 12 & 3 & 6 & 8 & 0 & 0 & 0 & 6 & 4 & 7 & 0 & 3 & 39 & 73 & 74 & 47 & 125 & 411 & 539 & 426 & 400 & 804 \\
\hline Bács-Kiskun & 99 & 42 & 23 & 180 & 259 & 360 & 633 & 286 & 271 & 353 & 528 & 672 & 838 & 741 & 1107 & 962 & 2285 & 1633 & 1696 & 1776 & 3887 & 2254 \\
\hline $\begin{array}{l}\text { Duna-Tisza köze } \\
\text { Danube-Tisza } \\
\text { Interfluve }\end{array}$ & 111 & 45 & 29 & 188 & 259 & 360 & 633 & 292 & 275 & 360 & 528 & 675 & 877 & 814 & 1181 & 1009 & 2410 & 2044 & 2235 & 2202 & 4287 & 3058 \\
\hline $\begin{array}{l}\text { Szabolcs-Szatmár- } \\
\text { Bereg }\end{array}$ & 2 & 4 & 0 & 3 & 0 & 0 & 0 & 0 & 0 & 3 & 1 & 0 & 4 & 2 & 0 & 0 & 8 & 54 & 61 & 25 & 15 & 18 \\
\hline Hajdú-Bihar & 47 & 9 & 38 & 37 & 133 & 207 & 697 & 312 & 259 & 274 & 133 & 75 & 225 & 144 & 263 & 649 & 849 & 1062 & 714 & 1248 & 801 & 1228 \\
\hline Jász-Nagykun-Szolnok & 32 & 38 & 73 & 15 & 61 & 67 & 213 & 59 & 50 & 157 & 310 & 98 & 477 & 800 & 328 & 1062 & 786 & 1005 & 813 & 1954 & 782 & 1171 \\
\hline Békés & 13 & 0 & 65 & 80 & 113 & 201 & 239 & 153 & 51 & 130 & 254 & 126 & 356 & 401 & 347 & 574 & 494 & 755 & 279 & 498 & 816 & 460 \\
\hline Csongrád & 12 & 16 & 0 & 12 & 2 & 15 & 7 & 16 & 23 & 19 & 47 & 40 & 111 & 53 & 176 & 183 & 606 & 676 & 644 & 461 & 777 & 606 \\
\hline $\begin{array}{l}\text { Tiszántúl } \\
\text { Transtisza }\end{array}$ & 106 & 67 & 176 & 147 & 309 & 490 & 1156 & 540 & 383 & 583 & 745 & 339 & 1173 & 1400 & 1114 & 2468 & 2743 & 3552 & 2511 & 4186 & 3191 & 3483 \\
\hline $\begin{array}{l}\text { Magyarország } \\
\text { összesen } \\
\text { Hungary total }\end{array}$ & 336 & 188 & 316 & 439 & 758 & 1243 & 2046 & 1150 & 1070 & 1749 & 2117 & 1908 & 2920 & 3478 & 3815 & 4918 & 6775 & 8456 & 8321 & 10439 & 10440 & 10485 \\
\hline
\end{tabular}


3. melléklet: A vadászható vadlúdfajok regionális és országos terítékeinek dinamikája Appendix 3: Number of huntable goose species in the bag on regional and national level

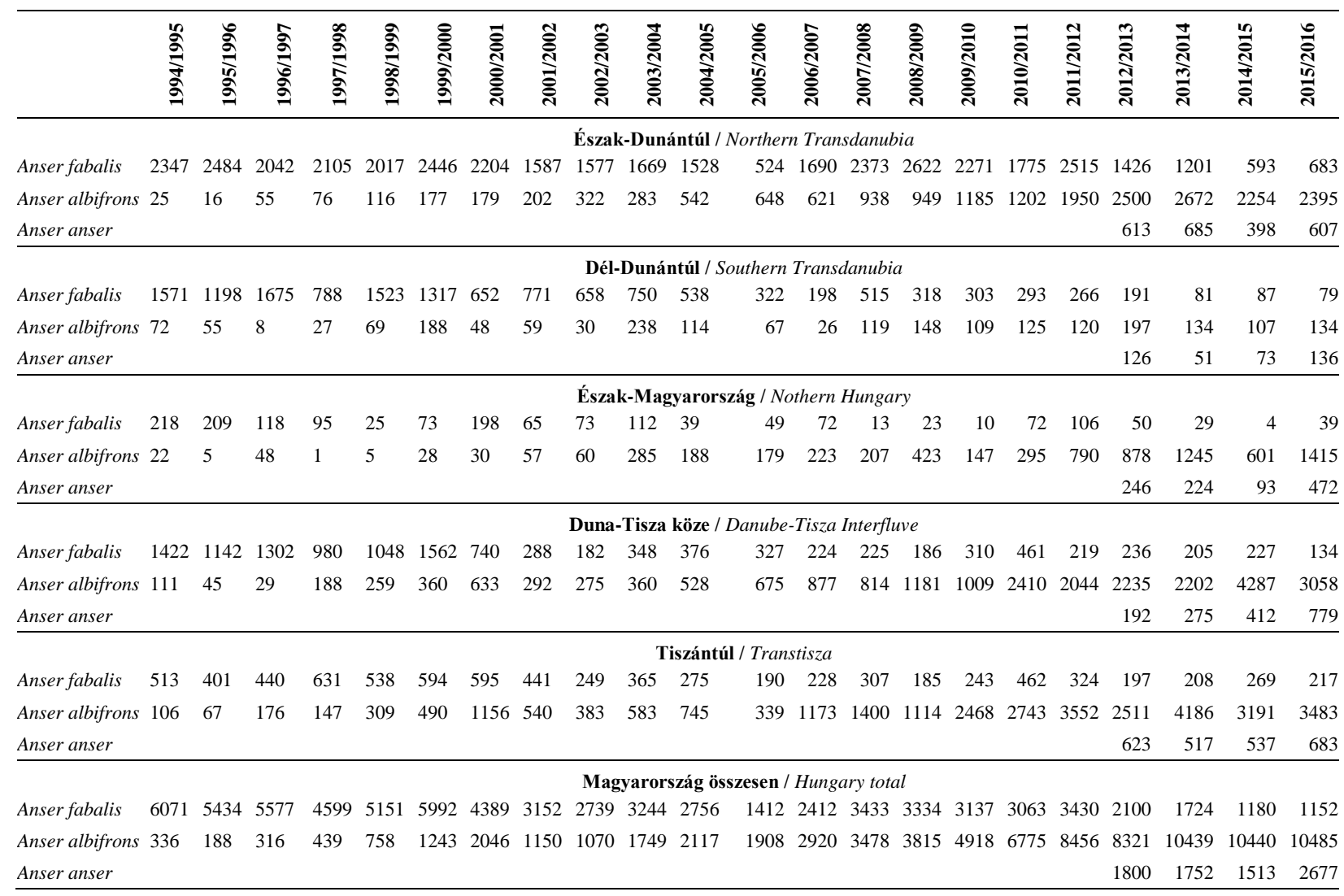




\section{4. melléklet: A vadászható vadlúdfajok regionális és országos terítékarányainak dinamikája}

Appendix 4: Ratio of huntable goose species in the bag on regional and national level

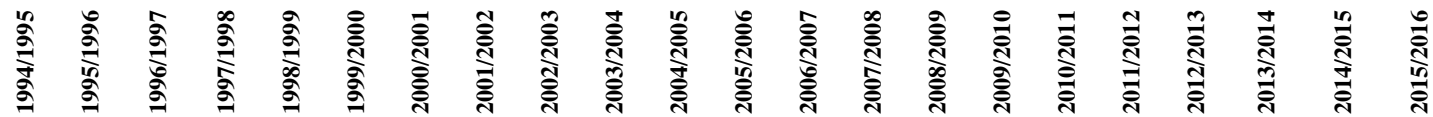

Észak-Dunántúl / Northern Transdanubia

\begin{tabular}{|c|c|c|c|c|c|c|c|c|c|c|c|c|c|c|c|c|c|c|c|c|c|c|}
\hline nser fabalis & $99 \%$ & $99 \%$ & $97 \%$ & $97 \%$ & $95 \%$ & $93 \%$ & $92 \%$ & $89 \%$ & $83 \%$ & $86 \%$ & $74 \%$ & $45 \%$ & $73 \%$ & $72 \%$ & $73 \%$ & $66 \%$ & $60 \%$ & $56 \%$ & $31 \%$ & $26 \%$ & $18 \%$ & 19 \\
\hline Anser albifrons & $1 \%$ & $1 \%$ & $3 \%$ & $3 \%$ & $5 \%$ & $7 \%$ & $8 \%$ & $11 \%$ & $17 \%$ & $14 \%$ & $26 \%$ & $55 \%$ & $27 \%$ & $28 \%$ & $27 \%$ & $34 \%$ & $40 \%$ & $44 \%$ & $55 \%$ & $59 \%$ & $69 \%$ & $65^{c}$ \\
\hline \multirow[t]{2}{*}{ Anser anser } & & & & & & & & & & & & & & & & & & & $14 \%$ & $15 \%$ & $12 \%$ & \\
\hline & \multicolumn{22}{|c|}{ Dél-Dunántúl / Southern Transdanubia } \\
\hline Anser fabalis & $96 \%$ & $96 \%$ & $100 \%$ & $97 \%$ & $96 \%$ & $88 \%$ & $93 \%$ & $93 \%$ & $96 \%$ & $76 \%$ & $83 \%$ & $83 \%$ & $88 \%$ & $81 \%$ & $68 \%$ & $74 \%$ & $70 \%$ & $69 \%$ & $37 \%$ & $30 \%$ & $33 \%$ & \\
\hline Anser albifrons & $4 \%$ & $4 \%$ & $0 \%$ & $3 \%$ & $4 \%$ & $12 \%$ & $7 \%$ & $7 \%$ & $4 \%$ & $24 \%$ & $17 \%$ & $17 \%$ & $12 \%$ & $19 \%$ & $32 \%$ & $26 \%$ & $30 \%$ & $31 \%$ & $38 \%$ & $50 \%$ & $40 \%$ & \\
\hline \multirow[t]{2}{*}{ Anser anser } & & & & & & & & & & & & & & & & & & & $25 \%$ & $19 \%$ & $27 \%$ & \\
\hline & \multicolumn{22}{|c|}{ Észak-Magyarország / Nothern Hungary } \\
\hline Anser fabalis & $91 \%$ & $98 \%$ & $71 \%$ & $99 \%$ & $83 \%$ & $72 \%$ & $87 \%$ & $53 \%$ & $55 \%$ & $28 \%$ & $17 \%$ & $21 \%$ & $24 \%$ & $6 \%$ & $5 \%$ & $6 \%$ & $20 \%$ & $12 \%$ & $4 \%$ & $2 \%$ & $1 \%$ & \\
\hline Anser albifrons & $9 \%$ & $2 \%$ & $29 \%$ & $1 \%$ & $17 \%$ & $28 \%$ & $13 \%$ & $47 \%$ & $45 \%$ & $72 \%$ & $83 \%$ & $79 \%$ & $76 \%$ & $94 \%$ & $95 \%$ & $94 \%$ & $80 \%$ & $88 \%$ & $75 \%$ & $83 \%$ & $86 \%$ & \\
\hline \multirow[t]{2}{*}{ Anser anser } & & & & & & & & & & & & & & & & & & & $21 \%$ & $15 \%$ & $13 \%$ & \\
\hline & \multicolumn{22}{|c|}{ Duna-Tisza köze / Danube-Tisza Interfluve } \\
\hline Anser fabalis & $93 \%$ & $96 \%$ & $98 \%$ & $84 \%$ & $80 \%$ & $81 \%$ & $54 \%$ & $50 \%$ & $40 \%$ & $49 \%$ & $42 \%$ & $33 \%$ & $20 \%$ & $22 \%$ & $14 \%$ & $24 \%$ & $16 \%$ & $10 \%$ & $9 \%$ & $8 \%$ & $5 \%$ & \\
\hline Anser albifrons & $7 \%$ & $4 \%$ & $2 \%$ & $16 \%$ & $20 \%$ & $19 \%$ & $46 \%$ & $50 \%$ & $60 \%$ & $51 \%$ & $58 \%$ & $67 \%$ & $80 \%$ & $78 \%$ & $86 \%$ & $76 \%$ & $84 \%$ & $90 \%$ & $84 \%$ & $82 \%$ & $87 \%$ & \\
\hline \multirow[t]{2}{*}{ Anser anser } & & & & & & & & & & & & & & & & & & & $7 \%$ & $10 \%$ & $8 \%$ & \\
\hline & \multicolumn{22}{|c|}{ Tiszántúl / Transtisza } \\
\hline Anser fabalis & $83 \%$ & $86 \%$ & $71 \%$ & $81 \%$ & $64 \%$ & $55 \%$ & $34 \%$ & $45 \%$ & $39 \%$ & $39 \%$ & $27 \%$ & $36 \%$ & $16 \%$ & $18 \%$ & $14 \%$ & $9 \%$ & $14 \%$ & $8 \%$ & $6 \%$ & $4 \%$ & $7 \%$ & \\
\hline Anser albifrons & $17 \%$ & $14 \%$ & $29 \%$ & $19 \%$ & $36 \%$ & $45 \%$ & $66 \%$ & $55 \%$ & $61 \%$ & $61 \%$ & $73 \%$ & $64 \%$ & $84 \%$ & $82 \%$ & $86 \%$ & $91 \%$ & $86 \%$ & $92 \%$ & $75 \%$ & $85 \%$ & $80 \%$ & \\
\hline \multirow[t]{2}{*}{ Anser anser } & & & & & & & & & & & & & & & & & & & $19 \%$ & $11 \%$ & $13 \%$ & \\
\hline & \multicolumn{22}{|c|}{ Magyarország összesen / Hungary total } \\
\hline Anser fabalis & $95 \%$ & $97 \%$ & $95 \%$ & $91 \%$ & $87 \%$ & $83 \%$ & $68 \%$ & $73 \%$ & $72 \%$ & $65 \%$ & $57 \%$ & $43 \%$ & $45 \%$ & $50 \%$ & $47 \%$ & $39 \%$ & $31 \%$ & $29 \%$ & $17 \%$ & $12 \%$ & $9 \%$ & \\
\hline Anser albifrons & $5 \%$ & $3 \%$ & $5 \%$ & $9 \%$ & $13 \%$ & $17 \%$ & $32 \%$ & $27 \%$ & $28 \%$ & $35 \%$ & $43 \%$ & $57 \%$ & $55 \%$ & $50 \%$ & $53 \%$ & $61 \%$ & $69 \%$ & $71 \%$ & $68 \%$ & $75 \%$ & $79 \%$ & \\
\hline Anser anser & & & & & & & & & & & & & & & & & & & $15 \%$ & $13 \%$ & $12 \%$ & \\
\hline
\end{tabular}




\section{5. melléklet: A tőkés réce terítéke Magyarországon, 1996-2016}

Appendix 5: Bag of Mallard in Hungary, 1996-2016

\begin{tabular}{|c|c|c|c|c|c|c|c|c|c|c|c|c|c|c|c|c|c|c|c|c|}
\hline $\begin{array}{l}\text { Megye, régió } \\
\text { County, region }\end{array}$ & $\frac{5}{2}$ & 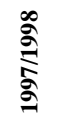 & $\underset{\stackrel{\partial}{\circ}}{\stackrel{\sigma}{\circ}}$ & ڤ્ڤ & 高 & 气ิે & 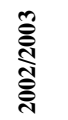 & 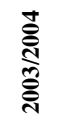 & & 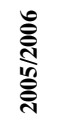 & 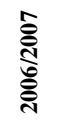 & 产 & 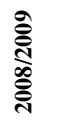 & ֻิ & $\underset{\overline{\bar{c}}}{\overline{\bar{̀}}}$ & 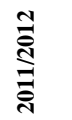 & 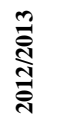 & 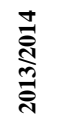 & 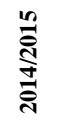 & 啇 \\
\hline Sopron & 4089 & 3878 & 4742 & 4382 & 3840 & 2375 & 2433 & 4220 & 2281 & 2051 & 1744 & 2485 & 4178 & 3070 & 2338 & 2305 & 2389 & 1962 & 1730 & 2415 \\
\hline Komárom-Esztergom & 1710 & 1999 & 2110 & 2134 & 1548 & 1142 & 967 & 420 & 510 & 508 & 483 & 1179 & 915 & 978 & 2309 & 1045 & 1254 & 1461 & 1253 & 1489 \\
\hline Vas & 1132 & 691 & 908 & 707 & 842 & 526 & 498 & 379 & 390 & 247 & 249 & 333 & 417 & 317 & 419 & 364 & 390 & 464 & 501 & 442 \\
\hline Veszprém & 778 & 885 & 3203 & 844 & 860 & 780 & 603 & 3084 & 580 & 502 & 361 & 559 & 437 & 431 & 532 & 579 & 533 & 695 & 639 & 660 \\
\hline Fejér & 2991 & 2628 & 3882 & 4342 & 4249 & 5634 & 2831 & 2427 & 2231 & 2265 & 3540 & 3456 & 2161 & 2095 & 1611 & 2317 & 2846 & 3661 & 2051 & 3288 \\
\hline $\begin{array}{l}\text { Észak-Dunántúl } \\
\text { Northern } \\
\text { Transdanubia } \\
\end{array}$ & 10700 & 10081 & 14845 & 12409 & 11339 & 10457 & 7332 & 10530 & 5992 & 5573 & 6377 & 8012 & 8108 & 6891 & 7209 & 6610 & 7412 & 8243 & 6174 & 8294 \\
\hline Zala & 893 & 2243 & 698 & 559 & 446 & 848 & 732 & 706 & 442 & 346 & 352 & 544 & 549 & 406 & 418 & 376 & 514 & 508 & 506 & 387 \\
\hline Somogy & 2347 & 1953 & 2167 & 2776 & 1937 & 4093 & 1742 & 1757 & 1888 & 1613 & 1410 & 1475 & 1399 & 1150 & 3807 & 1735 & 4063 & 886 & 763 & 972 \\
\hline olna & 4211 & 4194 & 3750 & 3672 & 3599 & 4661 & 4322 & 2269 & 2321 & 2024 & 2530 & 4057 & 1506 & 1602 & 1693 & 2393 & 2254 & 2672 & 1855 & 2031 \\
\hline Baranya & 1755 & 1740 & 1807 & 2113 & 1232 & 1216 & 1272 & 1327 & 710 & 470 & 672 & 813 & 711 & 668 & 648 & 901 & 600 & 588 & 527 & 529 \\
\hline $\begin{array}{l}\text { Dél-Dunántúl } \\
\text { Southern } \\
\text { Transdanubia }\end{array}$ & 9206 & 10130 & 8422 & 9120 & 7214 & 10818 & 8068 & 6059 & 5361 & 4453 & 4964 & 6889 & 4165 & 3826 & 6566 & 5405 & 7431 & 4654 & 3651 & 3919 \\
\hline Nógrád & 65 & 182 & 269 & 340 & 268 & 3058 & 248 & 156 & 200 & 76 & 114 & 215 & 94 & 78 & 98 & 87 & 88 & 129 & 74 & 116 \\
\hline Heves & 3038 & 3525 & 1822 & 5779 & 4573 & 3614 & 2581 & 5418 & 1271 & 1640 & 2620 & 1923 & 1516 & 1464 & 833 & 1732 & 677 & 1471 & 907 & 1741 \\
\hline $\begin{array}{l}\text { Borsod-Abaúj- } \\
\text { Zemplén }\end{array}$ & 4113 & 5760 & 5686 & 7483 & 4482 & 3802 & 3003 & 2385 & 1812 & 1919 & 2225 & 2547 & 2187 & 1761 & 1894 & 2957 & 1948 & 1816 & 1465 & 1013 \\
\hline $\begin{array}{l}\text { Észak-Magyarország } \\
\text { Northern Hungary }\end{array}$ & 16 & 9467 & 7777 & 13602 & 9323 & 10474 & 5832 & 7959 & 3283 & 3635 & 959 & 4685 & 797 & 3303 & 2825 & 1776 & 2713 & 3416 & 2446 & 2870 \\
\hline Pest & 5190 & 2403 & 2872 & 6582 & 3273 & 3817 & 3805 & 2860 & 2915 & 2267 & 2874 & 4092 & 3922 & 3276 & 3347 & 3534 & 4115 & 3647 & 2105 & 3523 \\
\hline Bács-Kiskun & 4752 & 6588 & 6941 & 7743 & 7459 & 5853 & 4259 & 3382 & 4239 & 4307 & 5078 & 5564 & 4925 & 5278 & 3410 & 4925 & 4054 & 3881 & 2713 & 3128 \\
\hline $\begin{array}{l}\text { Duna-Tisza köze } \\
\text { Danube-Tisza } \\
\text { Interfluve }\end{array}$ & 9942 & 8991 & 9813 & 14325 & 10732 & 9670 & 8064 & 6242 & 7154 & 6574 & 7952 & 9656 & 847 & 8554 & 6757 & 8459 & 8169 & 7528 & 4818 & 6651 \\
\hline $\begin{array}{l}\text { Szabolcs-Szatmár- } \\
\text { Bereg }\end{array}$ & 3196 & 3176 & 3969 & 5499 & 3016 & 5103 & 3199 & 2560 & 2004 & 1777 & 2331 & 2497 & 2709 & 2005 & 3886 & 6537 & 4256 & 3079 & 2063 & 1897 \\
\hline Hajdú-Bihar & 3427 & 7569 & 5240 & 13135 & 13072 & 9203 & 8524 & 8844 & 8850 & 4453 & 5668 & 5910 & 5630 & 3431 & 3280 & 5816 & 3159 & 3616 & 1943 & 2534 \\
\hline $\begin{array}{l}\text { Jász-Nagykun- } \\
\text { Szolnok }\end{array}$ & 6575 & 8764 & 6293 & 9595 & 14208 & 10688 & 6481 & 3441 & 6203 & 7971 & 10198 & 8566 & 8266 & 4542 & 5545 & 8898 & 5278 & 7363 & 4935 & 6558 \\
\hline Békés & 5301 & 6557 & 5575 & 6925 & 14649 & 13509 & 8549 & 4746 & 5268 & 7835 & 7006 & 5787 & 5199 & 3189 & 4488 & 7713 & 3938 & 6030 & 3524 & 4668 \\
\hline Csongrád & 3858 & 3188 & 4423 & 6512 & 6297 & 5974 & 4426 & 3031 & 2894 & 2593 & 3503 & 4164 & 3258 & 1608 & 3049 & 4916 & 2539 & 2795 & 2742 & 2742 \\
\hline $\begin{array}{l}\text { Tiszántúl } \\
\text { Transtisza }\end{array}$ & 22357 & 29254 & 25500 & 41666 & 51242 & 44477 & 31179 & 22622 & 25219 & 24629 & 28706 & 26924 & 25062 & 14775 & 20248 & 33880 & 19170 & 22883 & 15207 & 18399 \\
\hline $\begin{array}{l}\text { Magyarország } \\
\text { összesen }\end{array}$ & 02 & 6792 & 635 & 1122 & 89850 & 8589 & 475 & 53412 & 47009 & 44864 & 52958 & 56166 & 49979 & 37349 & 43605 & 59130 & 44895 & 16724 & 32296 & 40133 \\
\hline
\end{tabular}


6. melléklet: A csörgő réce terítéke Magyarországon, 1996-2012

Appendix 6: Bag of Eurasian Teal in Hungary, 1996-2012

\begin{tabular}{|c|c|c|c|c|c|c|c|c|c|c|c|c|c|c|c|c|}
\hline $\begin{array}{l}\text { Megye, régió } \\
\text { County, region }\end{array}$ & $\frac{\hat{\sigma}}{\delta}$ & $\underset{\sigma}{\stackrel{\circ}{\sigma}}$ & $\frac{\stackrel{\sigma}{\sigma}}{\stackrel{2}{\circ}}$ & 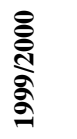 & 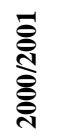 & 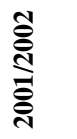 & ્ֶડ & 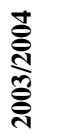 & 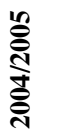 & 总 & 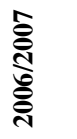 & & 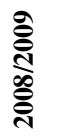 & 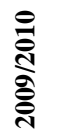 & $\begin{array}{l}\overline{\bar{J}} \\
\text { 을 }\end{array}$ & 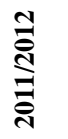 \\
\hline Győr-Moson-Sopron & 68 & 152 & 106 & 141 & 12 & 24 & 6 & 16 & 20 & 48 & 42 & 59 & 59 & 11 & 44 & 36 \\
\hline Komárom-Esztergom & 61 & 147 & 89 & 15 & 117 & 45 & 69 & 25 & 8 & 33 & 64 & 139 & 13 & 15 & 20 & 108 \\
\hline Vas & 0 & 9 & 7 & 6 & 2 & 4 & 5 & 1 & 13 & 0 & 0 & 4 & 12 & 15 & 14 & 0 \\
\hline Veszprém & 37 & 57 & 25 & 28 & 36 & 51 & 21 & 11 & 22 & 7 & 6 & 14 & 4 & 2 & 19 & 20 \\
\hline Fejér & 269 & 89 & 154 & 206 & 300 & 171 & 112 & 64 & 200 & 79 & 55 & 213 & 286 & 158 & 59 & 84 \\
\hline $\begin{array}{l}\text { Észak-Dunántúl } \\
\text { Northern Transdanubia }\end{array}$ & 435 & 454 & 381 & 396 & 467 & 295 & 213 & 117 & 263 & 167 & 167 & 429 & 374 & 201 & 156 & 248 \\
\hline Zala & 63 & 28 & 122 & 56 & 21 & 31 & 4 & 34 & 13 & 20 & 10 & 31 & 16 & 19 & 47 & 47 \\
\hline Somogy & 135 & 8 & 69 & 81 & 13 & 41 & 83 & 36 & 50 & 155 & 35 & 39 & 18 & 157 & 65 & 51 \\
\hline Tolna & 61 & 37 & 59 & 93 & 90 & 78 & 11 & 16 & 19 & 47 & 43 & 97 & 0 & 16 & 25 & 2 \\
\hline Baranya & 239 & 56 & 153 & 168 & 84 & 28 & 40 & 18 & 80 & 39 & 54 & 97 & 67 & 69 & 31 & 28 \\
\hline $\begin{array}{l}\text { Dél-Dunántúl } \\
\text { Southern Transdanubia }\end{array}$ & 498 & 129 & 403 & 398 & 208 & 178 & 138 & 104 & 162 & 261 & 142 & 264 & 101 & 261 & 168 & 128 \\
\hline Nógrád & 30 & 10 & 14 & 14 & 2 & 3 & 1 & 3 & 0 & 2 & 1 & 10 & 0 & 0 & 1 & 0 \\
\hline Heves & 972 & 75 & 64 & 854 & 1550 & 1299 & 104 & 97 & 24 & 52 & 556 & 307 & 169 & 142 & 45 & 126 \\
\hline Borsod-Abaúj-Zemplén & 129 & 134 & 151 & 113 & 107 & 147 & 137 & 39 & 42 & 55 & 49 & 25 & 14 & 60 & 41 & 12 \\
\hline $\begin{array}{l}\text { Észak-Magyarország } \\
\text { Northern Hungary }\end{array}$ & 1131 & 219 & 229 & 981 & 1659 & 1449 & 242 & 139 & 66 & 109 & 606 & 342 & 183 & 202 & 87 & 138 \\
\hline Pest & 68 & 101 & 117 & 107 & 139 & 39 & 43 & 24 & 32 & 23 & 38 & 42 & 47 & 54 & 41 & 125 \\
\hline Bács-Kiskun & 865 & 472 & 644 & 1073 & 492 & 955 & 202 & 236 & 118 & 216 & 307 & 439 & 325 & 247 & 418 & 172 \\
\hline $\begin{array}{l}\text { Duna-Tisza köze } \\
\text { Danube-Tisza Interfluve }\end{array}$ & 933 & 573 & 761 & 1180 & 631 & 994 & 245 & 260 & 150 & 239 & 345 & 481 & 372 & 301 & 459 & 297 \\
\hline Szabolcs-Szatmár-Bereg & 87 & 124 & 83 & 182 & 116 & 129 & 39 & 31 & 80 & 58 & 30 & 37 & 16 & 11 & 61 & 108 \\
\hline Hajdú-Bihar & 333 & 822 & 1045 & 549 & 836 & 676 & 379 & 373 & 330 & 268 & 478 & 338 & 217 & 87 & 137 & 130 \\
\hline Jász-Nagykun-Szolnok & 690 & 1111 & 959 & 784 & 1530 & 1887 & 866 & 773 & 776 & 801 & 999 & 1308 & 1035 & 1298 & 302 & 611 \\
\hline Békés & 85 & 542 & 164 & 367 & 365 & 603 & 333 & 265 & 185 & 167 & 293 & 397 & 142 & 110 & 124 & 130 \\
\hline Csongrád & 142 & 390 & 378 & 440 & 344 & 446 & 214 & 490 & 165 & 134 & 193 & 133 & 73 & 64 & 45 & 137 \\
\hline $\begin{array}{l}\text { Tiszántúl } \\
\text { Transtisza }\end{array}$ & 1337 & 2989 & 2629 & 2322 & 3191 & 3741 & 1831 & 1932 & 1536 & 1428 & 1993 & 2213 & 1483 & 1570 & 669 & 1116 \\
\hline $\begin{array}{l}\text { Magyarország összesen } \\
\text { Hungary total }\end{array}$ & 4334 & 4364 & 4403 & 5277 & 6156 & 6657 & 2669 & 2552 & 2177 & 2204 & 3253 & 3729 & 2513 & 2535 & 1539 & 1927 \\
\hline
\end{tabular}


7. melléklet: A böjti réce terítéke Magyarországon, 1996-2007 Appendix 7: Bag of Garganey in Hungary, 1996-2007

\begin{tabular}{|c|c|c|c|c|c|c|c|c|c|c|c|}
\hline $\begin{array}{l}\text { Megye, régió } \\
\text { County, region }\end{array}$ & $\frac{5}{2}$ & $\frac{\infty}{\stackrel{\circ}{\sigma}}$ & $\begin{array}{l}\stackrel{\circ}{\sigma} \\
\stackrel{\circ}{\sigma}\end{array}$ & 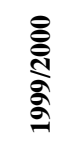 & 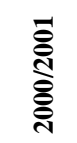 & 令 & 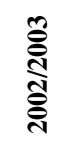 & 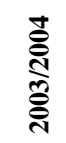 & 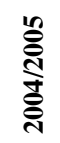 & 离 & 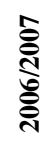 \\
\hline Győr-Moson-Sopron & 35 & 26 & 23 & 32 & 3 & 5 & 5 & 5 & 21 & 6 & 0 \\
\hline Komárom-Esztergom & 0 & 9 & 3 & 15 & 31 & 0 & 8 & 12 & 0 & 0 & 0 \\
\hline Vas & 0 & 0 & 0 & 0 & 0 & 0 & 32 & 0 & 0 & 0 & 0 \\
\hline Veszprém & 0 & 11 & 20 & 21 & 15 & 14 & 0 & 14 & 10 & 0 & 0 \\
\hline Fejér & 39 & 16 & 13 & 61 & 34 & 21 & 28 & 1 & 11 & 8 & 0 \\
\hline $\begin{array}{l}\text { Észak-Dunántúl } \\
\text { Northern Transdanubia }\end{array}$ & 74 & 62 & 59 & 129 & 83 & 40 & 73 & 32 & 42 & 14 & $\mathbf{0}$ \\
\hline Zala & 0 & 11 & 277 & 14 & 6 & 0 & 0 & 0 & 11 & 0 & 0 \\
\hline Somogy & 41 & 97 & 110 & 61 & 9 & 10 & 8 & 7 & 13 & 8 & 0 \\
\hline Tolna & 37 & 0 & 7 & 32 & 14 & 0 & 0 & 2 & 1 & 0 & 3 \\
\hline Baranya & 37 & 28 & 25 & 24 & 14 & 34 & 32 & 14 & 15 & 2 & 0 \\
\hline $\begin{array}{l}\text { Dél-Dunántúl } \\
\text { Southern Transdanubia } \\
\end{array}$ & 115 & 136 & 419 & 131 & 43 & 44 & 40 & 23 & 40 & 10 & 3 \\
\hline Nógrád & 0 & 0 & 0 & 0 & 1 & 0 & 0 & 0 & 0 & 0 & 0 \\
\hline Heves & 72 & 40 & 32 & 281 & 35 & 3 & 15 & 3 & 0 & 20 & 3 \\
\hline Borsod-Abaúj-Zemplén & 0 & 5 & 85 & 42 & 24 & 22 & 18 & 10 & 0 & 0 & 87 \\
\hline $\begin{array}{l}\text { Észak-Magyarország } \\
\text { Northern Hungary }\end{array}$ & 72 & 45 & 117 & 323 & 60 & 25 & 33 & 13 & $\mathbf{0}$ & 20 & 90 \\
\hline Pest & 3 & 9 & 23 & 41 & 3 & 0 & 12 & 0 & 0 & 0 & 0 \\
\hline Bács-Kiskun & 226 & 352 & 761 & 444 & 132 & 121 & 66 & 52 & 7 & 20 & 0 \\
\hline $\begin{array}{l}\text { Duna-Tisza köze } \\
\text { Danube-Tisza Interfluve }\end{array}$ & 229 & 361 & 784 & 485 & 135 & 121 & 78 & 52 & 7 & 20 & 0 \\
\hline Szabolcs-Szatmár-Bereg & 15 & 24 & 5 & 26 & 14 & 1 & 1 & 0 & 51 & 51 & 0 \\
\hline Hajdú-Bihar & 0 & 203 & 412 & 111 & 182 & 105 & 81 & 62 & 38 & 0 & 6 \\
\hline Jász-Nagykun-Szolnok & 176 & 180 & 169 & 107 & 249 & 299 & 38 & 70 & 0 & 0 & 37 \\
\hline Békés & 65 & 20 & 46 & 49 & 212 & 192 & 138 & 46 & 11 & 0 & 51 \\
\hline Csongrád & 95 & 36 & 35 & 65 & 33 & 27 & 35 & 12 & 0 & 6 & 0 \\
\hline $\begin{array}{l}\text { Tiszántúl } \\
\text { Transtisza }\end{array}$ & 351 & 463 & 667 & 358 & 690 & 624 & 293 & 190 & 100 & 57 & 94 \\
\hline $\begin{array}{l}\text { Magyarország összesen } \\
\text { Hungary total }\end{array}$ & 841 & 1067 & 2046 & 1426 & 1011 & 854 & 517 & 310 & 189 & 121 & 187 \\
\hline
\end{tabular}


8. melléklet: A barátréce terítéke Magyarországon, 1996-2008 Appendix 8: Bag of Common Pochard in Hungary, 1996-2008

\begin{tabular}{|c|c|c|c|c|c|c|c|c|c|c|c|c|}
\hline $\begin{array}{l}\text { Megye, régió } \\
\text { County, region }\end{array}$ & $\begin{array}{l}\hat{\sigma} \\
\stackrel{\sigma}{\sigma}\end{array}$ & $\stackrel{\infty}{\stackrel{\circ}{\sigma}}$ & $\begin{array}{l}\stackrel{\partial}{\circ} \\
\stackrel{2}{\circ}\end{array}$ & 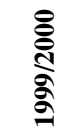 & 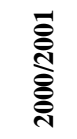 & 令 & 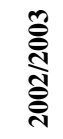 & 突 & 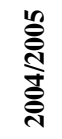 & 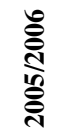 & 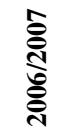 & 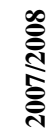 \\
\hline Győr-Moson-Sopron & 3 & 4 & 13 & 0 & 0 & 1 & 0 & 0 & 5 & 29 & 4 & 3 \\
\hline Komárom-Esztergom & 73 & 92 & 0 & 11 & 69 & 21 & 43 & 22 & 11 & 10 & 18 & 2 \\
\hline Vas & 0 & 0 & 0 & 0 & 0 & 0 & 0 & 0 & 1 & 0 & 1 & 0 \\
\hline Veszprém & 3 & 15 & 15 & 30 & 0 & 10 & 0 & 8 & 6 & 0 & 0 & 0 \\
\hline Fejér & 238 & 81 & 159 & 181 & 176 & 125 & 53 & 36 & 32 & 13 & 11 & 85 \\
\hline $\begin{array}{l}\text { Észak-Dunántúl } \\
\text { Northern Transdanubia }\end{array}$ & 317 & 192 & 187 & 222 & 245 & 157 & 96 & 66 & 55 & 52 & 34 & 90 \\
\hline Zala & 10 & 5 & 43 & 28 & 1 & 0 & 33 & 0 & 39 & 40 & 0 & 2 \\
\hline Somogy & 76 & 10 & 17 & 43 & 7 & 38 & 41 & 23 & 22 & 17 & 6 & 12 \\
\hline Tolna & 14 & 2 & 4 & 0 & 5 & 22 & 7 & 8 & 10 & 0 & 2 & 9 \\
\hline Baranya & 17 & 1 & 35 & 30 & 53 & 0 & 2 & 20 & 9 & 3 & 6 & 2 \\
\hline $\begin{array}{l}\text { Dél-Dunántúl } \\
\text { Southern Transdanubia }\end{array}$ & 117 & 18 & 99 & 101 & 66 & 60 & 83 & 51 & 80 & 60 & 14 & 25 \\
\hline Nógrád & 0 & 2 & 0 & 0 & 0 & 0 & 0 & 0 & 0 & 0 & 0 & 0 \\
\hline Heves & 82 & 20 & 24 & 415 & 106 & 10 & 21 & 1 & 0 & 2 & 1 & 6 \\
\hline Borsod-Abaúj-Zemplén & 34 & 36 & 50 & 25 & 9 & 12 & 10 & 9 & 2 & 0 & 2 & 0 \\
\hline $\begin{array}{l}\text { Észak-Magyarország } \\
\text { Northern Hungary }\end{array}$ & 116 & 58 & 74 & 440 & 115 & 22 & 31 & 10 & 2 & 2 & 3 & 6 \\
\hline Pest & 23 & 42 & 36 & 2 & 66 & 9 & 48 & 16 & 0 & 1 & 1 & 1 \\
\hline Bács-Kiskun & 0 & 134 & 202 & 395 & 131 & 180 & 65 & 73 & 2 & 61 & 107 & 49 \\
\hline $\begin{array}{l}\text { Duna-Tisza köze } \\
\text { Danube-Tisza Interfluve }\end{array}$ & 23 & 176 & 238 & 397 & 197 & 189 & 113 & 89 & 2 & 62 & 108 & 50 \\
\hline Szabolcs-Szatmár-Bereg & 20 & 42 & 67 & 111 & 84 & 43 & 51 & 13 & 16 & 15 & 9 & 0 \\
\hline Hajdú-Bihar & 735 & 1062 & 1517 & 1213 & 697 & 354 & 275 & 116 & 197 & 83 & 201 & 206 \\
\hline Jász-Nagykun-Szolnok & 155 & 410 & 230 & 364 & 144 & 188 & 144 & 108 & 76 & 52 & 61 & 44 \\
\hline Békés & 24 & 40 & 47 & 63 & 122 & 116 & 73 & 18 & 16 & 1 & 2 & 0 \\
\hline Csongrád & 239 & 137 & 393 & 164 & 135 & 47 & 34 & 66 & 1 & 12 & 2 & 27 \\
\hline $\begin{array}{l}\text { Tiszántúl } \\
\text { Transtisza }\end{array}$ & 1173 & 1691 & 2254 & 1915 & 1182 & 748 & $\mathbf{5 7 7}$ & 321 & 306 & 163 & 275 & 277 \\
\hline $\begin{array}{l}\text { Magyarország összesen } \\
\text { Hungary total }\end{array}$ & 1746 & 2135 & 2852 & 3075 & 1805 & 1176 & 900 & 537 & 445 & 339 & 434 & 448 \\
\hline
\end{tabular}


9. melléklet: A kerceréce terítéke Magyarországon, 1996-2012

Appendix 9: Bag of Common Goldeneye in Hungary, 1996-2012

\begin{tabular}{|c|c|c|c|c|c|c|c|c|c|c|c|c|c|c|c|c|}
\hline $\begin{array}{l}\text { Megye, régió } \\
\text { County, region }\end{array}$ & 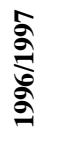 & $\underset{\sigma}{\stackrel{2}{\sigma}}$ & $\begin{array}{l}\stackrel{\partial}{\partial} \\
\text { gे }\end{array}$ & 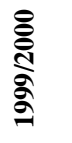 & 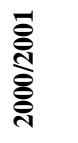 & 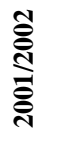 & 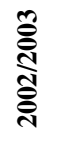 & 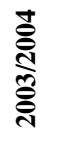 & 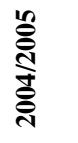 & 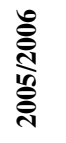 & 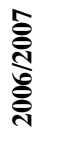 & 突 & 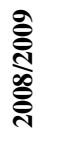 & 옳 & 콩 & 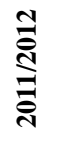 \\
\hline Győr-Moson-Sopron & 2 & 5 & 0 & 0 & 0 & 0 & 0 & 0 & 0 & 0 & 0 & 0 & 1 & 1 & 8 & 2 \\
\hline Komárom-Esztergom & 1 & 0 & 0 & 0 & 43 & 0 & 0 & 3 & 0 & 0 & 0 & 0 & 0 & 0 & 0 & 0 \\
\hline Vas & 0 & 0 & 0 & 0 & 0 & 0 & 0 & 0 & 0 & 0 & 0 & 0 & 0 & 0 & 0 & 0 \\
\hline Veszprém & 0 & 2 & 2 & 0 & 0 & 0 & 0 & 1 & 0 & 0 & 0 & 0 & 0 & 0 & 0 & 0 \\
\hline Fejér & 17 & 20 & 3 & 18 & 51 & 5 & 10 & 0 & 2 & 0 & 0 & 0 & 0 & 0 & 1 & 0 \\
\hline $\begin{array}{l}\text { Észak-Dunántúl } \\
\text { Northern Transdanubia }\end{array}$ & 20 & 27 & 5 & 18 & 94 & 5 & 10 & 4 & 2 & $\mathbf{0}$ & $\mathbf{0}$ & $\mathbf{0}$ & 1 & 1 & 9 & 2 \\
\hline Zala & 0 & 1 & 0 & 0 & 0 & 0 & 0 & 0 & 0 & 0 & 47 & 20 & 0 & 0 & 0 & 0 \\
\hline Somogy & 1 & 0 & 0 & 0 & 0 & 0 & 0 & 0 & 5 & 3 & 0 & 0 & 0 & 0 & 0 & 0 \\
\hline Tolna & 0 & 0 & 0 & 0 & 0 & 7 & 5 & 2 & 0 & 4 & 3 & 15 & 0 & 4 & 6 & 0 \\
\hline Baranya & 0 & 0 & 12 & 2 & 0 & 1 & 4 & 0 & 15 & 0 & 4 & 0 & 0 & 0 & 0 & 0 \\
\hline $\begin{array}{l}\text { Dél-Dunántúl } \\
\text { Southern Transdanubia }\end{array}$ & 1 & 1 & 12 & 2 & 0 & 8 & 9 & 2 & 20 & 7 & 54 & 35 & 0 & 4 & 6 & 0 \\
\hline Nógrád & 0 & 0 & 0 & 0 & 0 & 0 & 0 & 0 & 0 & 0 & 0 & 0 & 0 & 0 & 0 & $\overline{0}$ \\
\hline Heves & 3 & 0 & 10 & 70 & 7 & 0 & 0 & 0 & 0 & 0 & 0 & 0 & 0 & 0 & 0 & 3 \\
\hline Borsod-Abaúj-Zemplén & 0 & 0 & 14 & 0 & 5 & 5 & 0 & 0 & 3 & 0 & 0 & 0 & 0 & 0 & 0 & 15 \\
\hline $\begin{array}{l}\text { Észak-Magyarország } \\
\text { Northern Hungary } \\
\end{array}$ & 3 & $\mathbf{0}$ & 24 & 70 & 12 & 5 & $\mathbf{0}$ & $\mathbf{0}$ & 3 & $\mathbf{0}$ & $\mathbf{0}$ & $\mathbf{0}$ & $\mathbf{0}$ & $\mathbf{0}$ & $\mathbf{0}$ & 18 \\
\hline Pest & 0 & 14 & 9 & 1 & 1 & 1 & 0 & 0 & 6 & 4 & 0 & 1 & 4 & 6 & 0 & 0 \\
\hline Bács-Kiskun & 0 & 36 & 74 & 46 & 11 & 49 & 22 & 25 & 5 & 4 & 12 & 10 & 10 & 78 & 18 & 0 \\
\hline $\begin{array}{l}\text { Duna-Tisza köze } \\
\text { Danube-Tisza Interfluve } \\
\end{array}$ & $\mathbf{0}$ & 50 & 83 & 47 & 12 & 50 & 22 & 25 & 11 & 8 & 12 & 11 & 14 & 84 & 18 & $\mathbf{0}$ \\
\hline Szabolcs-Szatmár-Bereg & 0 & 0 & 0 & 0 & 0 & 0 & 0 & 0 & 0 & 0 & 0 & 0 & 0 & 0 & 0 & 0 \\
\hline Hajdú-Bihar & 10 & 151 & 40 & 25 & 117 & 58 & 80 & 15 & 15 & 20 & 20 & 0 & 27 & 36 & 11 & 0 \\
\hline Jász-Nagykun-Szolnok & 31 & 46 & 9 & 6 & 324 & 0 & 1 & 0 & 0 & 0 & 0 & 4 & 0 & 1 & 0 & 0 \\
\hline Békés & 250 & 176 & 39 & 80 & 196 & 202 & 62 & 12 & 7 & 0 & 0 & 133 & 10 & 28 & 0 & 6 \\
\hline Csongrád & 11 & 5 & 2 & 0 & 0 & 2 & 0 & 0 & 1 & 0 & 0 & 0 & 0 & 0 & 0 & 4 \\
\hline $\begin{array}{l}\text { Tiszántúl } \\
\text { Transtisza }\end{array}$ & 302 & 378 & 90 & 111 & 637 & 262 & 143 & 27 & 23 & 20 & 20 & 137 & 37 & 65 & 11 & 10 \\
\hline $\begin{array}{l}\text { Magyarország összesen } \\
\text { Hungary total }\end{array}$ & 326 & 456 & 214 & 248 & 755 & 330 & 184 & 58 & 59 & 35 & 86 & 183 & 52 & 154 & 44 & 30 \\
\hline
\end{tabular}


10. melléklet: A szárcsa terítéke Magyarországon, 1996-2016 Appendix 10: Bag of Eurasian Coot in Hungary, 1996-2016

\begin{tabular}{|c|c|c|c|c|c|c|c|c|c|c|c|c|c|c|c|c|c|c|c|c|}
\hline $\begin{array}{l}\text { Megye, régió } \\
\text { County, region }\end{array}$ & $\underset{\sigma}{\hat{\sigma}}$ & $\underset{\sigma}{\stackrel{\sigma}{\sigma}}$ & $\begin{array}{l}\stackrel{\sigma}{\sigma} \\
\stackrel{\sigma}{\circ}\end{array}$ & 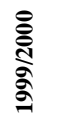 & 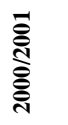 & 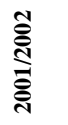 & 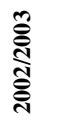 & 志 & 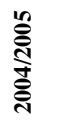 & 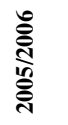 & 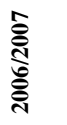 & 产 & 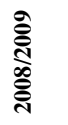 & 옿 & 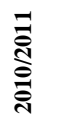 & 胥 & 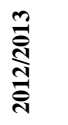 & 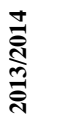 & $\frac{n}{\stackrel{\widetilde{N}}{\sigma}}$ & 商 \\
\hline Győr-Moson-Sopron & 98 & 120 & 38 & 154 & 195 & 55 & 71 & 91 & 29 & 28 & 23 & 24 & 230 & 208 & 120 & 111 & 136 & 14 & 69 & 96 \\
\hline Komárom-Esztergom & 1129 & 703 & 186 & 1009 & 355 & 438 & 195 & 181 & 92 & 105 & 22 & 259 & 30 & 27 & 59 & 187 & 11 & 8 & 27 & 39 \\
\hline Vas & 0 & 7 & 21 & 1 & 7 & 0 & 1 & 0 & 0 & 0 & 0 & 0 & 2 & 0 & 6 & 3 & 0 & 2 & 0 & 3 \\
\hline Veszprém & 0 & 13 & 11 & 4 & 6 & 0 & 0 & 0 & 1 & 0 & 0 & 9 & 2 & 9 & 3 & 3 & 0 & 17 & 0 & 3 \\
\hline Fejér & 354 & 418 & 365 & 352 & 137 & 377 & 137 & 76 & 94 & 106 & 125 & 159 & 272 & 86 & 317 & 73 & 407 & 75 & 49 & 44 \\
\hline $\begin{array}{l}\text { Észak-Dunántúl } \\
\text { Northern Transdanubia }\end{array}$ & 1581 & 1261 & 621 & 1520 & 700 & 870 & 404 & 348 & 216 & 239 & 170 & 451 & 536 & 330 & 505 & 377 & 554 & 116 & 145 & 185 \\
\hline Zala & 64 & 83 & 349 & 158 & 44 & 77 & 111 & 0 & 3 & 5 & 0 & 6 & 0 & 0 & 15 & 20 & 0 & 0 & 10 & 0 \\
\hline Somogy & 184 & 112 & 152 & 186 & 139 & 128 & 118 & 43 & 66 & 104 & 67 & 53 & 58 & 51 & 55 & 94 & 46 & 24 & 29 & 29 \\
\hline Tolna & 347 & 187 & 259 & 295 & 151 & 112 & 139 & 83 & 64 & 18 & 20 & 91 & 43 & 40 & 40 & 28 & 67 & 50 & 97 & 60 \\
\hline Baranya & 103 & 132 & 132 & 131 & 90 & 48 & 81 & 46 & 96 & 45 & 58 & 49 & 28 & 32 & 22 & 33 & 28 & 8 & 16 & 29 \\
\hline $\begin{array}{l}\text { Dél-Dunántúl } \\
\text { Southern Transdanubia }\end{array}$ & 698 & 514 & 892 & 770 & 424 & 365 & 449 & 172 & 229 & 172 & 145 & 199 & 129 & 123 & 132 & 175 & 141 & 82 & 152 & 118 \\
\hline Nógrád & 15 & 7 & 7 & 0 & 0 & 0 & 0 & 0 & 0 & 0 & 0 & 0 & 0 & 0 & 0 & 0 & 0 & 0 & 0 & 0 \\
\hline Heves & 46 & 27 & 72 & 410 & 599 & 23 & 22 & 20 & 50 & 309 & 119 & 67 & 16 & 8 & 0 & 0 & 0 & 2 & 6 & 129 \\
\hline Borsod-Abaúj-Zemplén & 52 & 66 & 135 & 63 & 127 & 59 & 20 & 8 & 10 & 34 & 35 & 29 & 16 & 26 & 10 & 34 & 25 & 0 & 0 & 0 \\
\hline $\begin{array}{l}\text { Észak-Magyarország } \\
\text { Northern Hungary }\end{array}$ & 113 & 100 & 214 & 473 & 726 & 82 & 42 & 28 & 60 & 343 & 154 & 96 & 32 & 34 & 10 & 34 & 25 & 2 & 6 & 129 \\
\hline Pest & 141 & 240 & 163 & 170 & 88 & 222 & 91 & 40 & 161 & 151 & 119 & 123 & 202 & 175 & 121 & 189 & 110 & 88 & 182 & 144 \\
\hline Bács-Kiskun & 454 & 358 & 468 & 743 & 590 & 367 & 88 & 276 & 282 & 348 & 361 & 165 & 138 & 149 & 601 & 157 & 127 & 60 & 157 & 227 \\
\hline $\begin{array}{l}\text { Duna-Tisza köze } \\
\text { Danube-Tisza Interfluve }\end{array}$ & 595 & 598 & 631 & 913 & 678 & 589 & 179 & 316 & 443 & 499 & 480 & 288 & 340 & 324 & 722 & 346 & 237 & 148 & 339 & 371 \\
\hline Szabolcs-Szatmár-Bereg & 22 & 80 & 36 & 134 & 74 & 3 & 218 & 5 & 0 & 113 & 19 & 6 & 0 & 0 & 45 & 372 & 22 & 16 & 57 & 29 \\
\hline Hajdú-Bihar & 107 & 717 & 853 & 237 & 969 & 277 & 151 & 194 & 220 & 50 & 138 & 20 & 0 & 60 & 20 & 4 & 49 & 24 & 0 & 39 \\
\hline Jász-Nagykun-Szolnok & 898 & 782 & 2552 & 1885 & 324 & 1123 & 441 & 552 & 790 & 1482 & 1833 & 859 & 868 & 633 & 1103 & 499 & 272 & 544 & 303 & 271 \\
\hline Békés & 116 & 85 & 127 & 177 & 384 & 55 & 81 & 81 & 96 & 57 & 323 & 119 & 36 & 57 & 41 & 235 & 23 & 94 & 200 & 34 \\
\hline Csongrád & 123 & 127 & 430 & 298 & 108 & 63 & 101 & 86 & 47 & 30 & 64 & 24 & 5 & 12 & 124 & 232 & 0 & 871 & 21 & 5 \\
\hline $\begin{array}{l}\text { Tiszántúl } \\
\text { Transtisza } \\
\end{array}$ & 1266 & 1791 & 3998 & 2731 & 1859 & 1521 & 992 & 918 & 1153 & 1732 & 2377 & 1028 & 909 & 762 & 1333 & 1342 & 366 & 1549 & 581 & 378 \\
\hline $\begin{array}{l}\text { Magyarország összesen } \\
\text { Hungary total }\end{array}$ & 4253 & 4264 & 6356 & 6407 & 4387 & 3427 & 2066 & 1782 & 2101 & 2985 & 3326 & 2062 & 1946 & 1573 & 2702 & 2274 & 1323 & 1897 & 1223 & 1181 \\
\hline
\end{tabular}




\section{1. melléklet: A vadászható récefajok és a szárcsa regionális és országos terítékeinek dinamikája}

Appendix 11: Number of huntable duck species and Cootin the bag on regional and national level

商

Észak-Dunántúl / Northern Transdanubia

Anas plathyrynchos $107001008114845124091133910457 \quad 7332 \quad 10530 \quad 5992 \quad 5573 \quad 6377 \quad 8012 \quad 8108 \quad 6891 \quad 7209 \quad 6610 \quad 7412 \quad 8243 \quad 6174 \quad 8294$

\begin{tabular}{|c|c|c|c|c|c|c|c|c|c|c|c|c|c|c|c|c|c|c|c|c|}
\hline Anas querquedula & 74 & 62 & 59 & 129 & 83 & 40 & 73 & 32 & 42 & 14 & 0 & & & & & & & & & \\
\hline Anas crecca & 435 & 454 & 381 & 396 & 467 & 295 & 213 & 117 & 263 & 167 & 167 & 429 & 374 & 201 & 156 & 248 & & & & \\
\hline Aythya ferina & 317 & 192 & 187 & 222 & 245 & 157 & 96 & 66 & 55 & 52 & 34 & 90 & & & & & & & & \\
\hline $\begin{array}{l}\text { Bucephala } \\
\text { clangula }\end{array}$ & 20 & 27 & 5 & 18 & 94 & 5 & 10 & 4 & 2 & 0 & 0 & 0 & 1 & 1 & 9 & 2 & & & & \\
\hline \multirow[t]{2}{*}{ Fulica atra } & 1581 & 1261 & 621 & 1520 & 700 & 870 & 404 & 348 & 216 & 239 & 170 & 451 & 536 & 330 & 505 & 377 & 554 & 116 & 145 & 185 \\
\hline & \multicolumn{20}{|c|}{ Dél-Dunántúl / Southern Transdanubia } \\
\hline Anas plathyrynchos & 9206 & 10130 & 8422 & 9120 & 7214 & 10818 & 8068 & 6059 & 5361 & 4453 & 4964 & 6889 & 4165 & 3826 & 6566 & 5405 & 7431 & 4654 & 3651 & 3919 \\
\hline Anas querquedula & 115 & 136 & 419 & 131 & 43 & 44 & 40 & 23 & 40 & 10 & 3 & & & & & & & & & \\
\hline Anas crecca & 498 & 129 & 403 & 398 & 208 & 178 & 138 & 104 & 162 & 261 & 142 & 264 & 101 & 261 & 168 & 128 & & & & \\
\hline Aythya ferina & 117 & 18 & 99 & 101 & 66 & 60 & 83 & 51 & 80 & 60 & 14 & 25 & & & & & & & & \\
\hline $\begin{array}{l}\text { Bucephala } \\
\text { clangula }\end{array}$ & 1 & 1 & 12 & 2 & 0 & 8 & 9 & 2 & 20 & 7 & 54 & 35 & 0 & 4 & 6 & 0 & & & & \\
\hline Fulica atra & 698 & 514 & 892 & 770 & 424 & 365 & 449 & 172 & 229 & 172 & 145 & 199 & 129 & 123 & 132 & 175 & 141 & 82 & 152 & 118 \\
\hline
\end{tabular}

Észak-Magyarország / Nothern Hungary

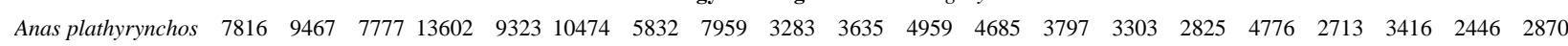

$\begin{array}{llllllllllll}\text { Anas querquedula } & 72 & 45 & 117 & 323 & 60 & 25 & 33 & 13 & 0 & 20 & 90\end{array}$

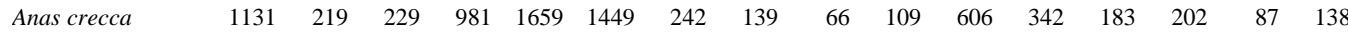

$\begin{array}{lllllllllllllll}\text { Aythya ferina } & 116 & 58 & 74 & 440 & 115 & 22 & 31 & 10 & 2 & 2 & 3 & 6\end{array}$

$\begin{array}{lllllllllllllllllll}\begin{array}{l}\text { Bucephala } \\ \text { clangula }\end{array} & 3 & 0 & 24 & 70 & 12 & 5 & 0 & 0 & 3 & 0 & 0 & 0 & 0 & 0 & 0 & 18\end{array}$

\begin{tabular}{llllllllllllllllllllll} 
Fulica atra & 113 & 100 & 214 & 473 & 726 & 82 & 42 & 28 & 60 & 343 & 154 & 96 & 32 & 34 & 10 & 34 & 25 & 2 & 6 & 129 \\
\hline
\end{tabular}

Duna-Tisza köze / Danube-Tisza Interfluve

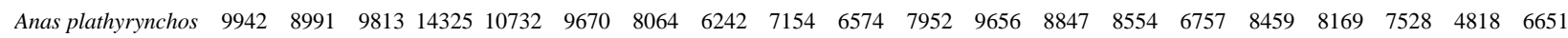

$\begin{array}{lllllllllllll}\text { Anas querquedula } & 229 & 361 & 784 & 485 & 135 & 121 & 78 & 52 & 7 & 20 & 0\end{array}$

$\begin{array}{lllllllllllllllll}\text { Anas crecca } & 933 & 573 & 761 & 1180 & 631 & 994 & 245 & 260 & 150 & 239 & 345 & 481 & 372 & 301 & 459 & 297\end{array}$

$\begin{array}{llllllllllllll}\text { Aythya ferina } & 23 & 176 & 238 & 397 & 197 & 189 & 113 & 89 & 2 & 62 & 108 & 50\end{array}$

$\begin{array}{llllllllllllllllll}\begin{array}{l}\text { Bucephala } \\ \text { clangula }\end{array} & 0 & 50 & 83 & 47 & 12 & 50 & 22 & 25 & 11 & 8 & 12 & 11 & 14 & 84 & 18 & 0\end{array}$

\begin{tabular}{lllllllllllllllllllll} 
Fulica atra & 595 & 598 & 631 & 913 & 678 & 589 & 179 & 316 & 443 & 499 & 480 & 288 & 340 & 324 & 722 & 346 & 237 & 148 & 339 & 371 \\
\hline
\end{tabular}

Tiszántúl / Transtisza

Anas plathyrynchos 2235729254255004166651242444773117922622252192462928706269242506214775202483388019170228831520718399

$\begin{array}{llllllllllll}\text { Anas querquedula } & 351 & 463 & 667 & 358 & 690 & 624 & 293 & 190 & 100 & 57 & 94\end{array}$

$\begin{array}{lllllllllllllllll}\text { Anas crecca } & 1337 & 2989 & 2629 & 2322 & 3191 & 3741 & 1831 & 1932 & 1536 & 1428 & 1993 & 2213 & 1483 & 1570 & 669 & 1116\end{array}$

$\begin{array}{lllllllllllll}\text { Aythya ferina } & 1173 & 1691 & 2254 & 1915 & 1182 & 748 & 577 & 321 & 306 & 163 & 275 & 277\end{array}$

$\begin{array}{lllllllllllllllll}\begin{array}{l}\text { Bucephala } \\ \text { clangula }\end{array} & 302 & 378 & 90 & 111 & 637 & 262 & 143 & 27 & 23 & 20 & 20 & 137 & 37 & 65 & 11 & 10\end{array}$

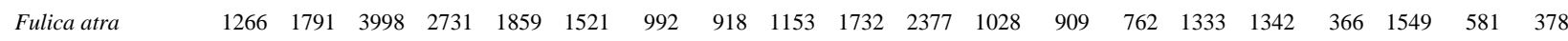

Magyarország összesen / Hungary total

Anas plathyrynchos 6002167923663579112289850858966047553412470094486452958561664997937349436055913044895467243229640133

$\begin{array}{llllllllllll}\text { Anas querquedula } & 841 & 1067 & 2046 & 1426 & 1011 & 854 & 517 & 310 & 189 & 121 & 187\end{array}$

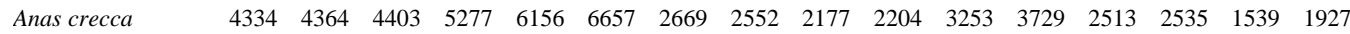

$\begin{array}{lllllllllllll}\text { Aythya ferina } & 1746 & 2135 & 2852 & 3075 & 1805 & 1176 & 900 & 537 & 445 & 339 & 434 & 448\end{array}$

$\begin{array}{lllllllllllllllll}\text { Bucephala } & 326 & 456 & 214 & 248 & 755 & 330 & 184 & 58 & 59 & 35 & 86 & 183 & 52 & 154 & 44 & 30\end{array}$

$\begin{array}{lllllllllllllllllllll}\text { Fulica atra } & 4253 & 4264 & 6356 & 6407 & 4387 & 3427 & 2066 & 1782 & 2101 & 2985 & 3326 & 2062 & 1946 & 1573 & 2702 & 2274 & 1323 & 1897 & 1223 & 1181\end{array}$ 


\section{2. melléklet: A vadászható récefajok és a szárcsa regionális és országos terítékarányainak dinamikája}

Appendix 12: Ratio of huntable duck species and Coot in the bag on regional and national level

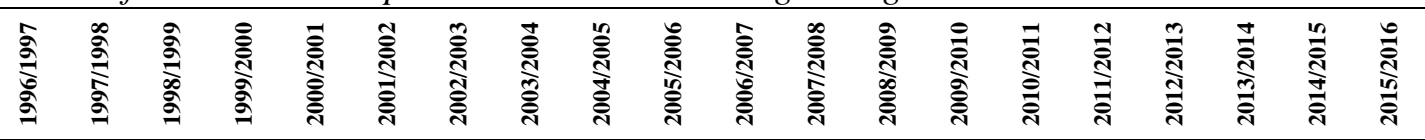

Észak-Dunántúl / Northern Transdanubia

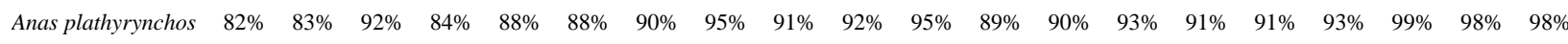
$\begin{array}{llllllllllll}\text { Anas querquedula } & 1 \% & 1 \% & 0 \% & 1 \% & 1 \% & 0 \% & 1 \% & 0 \% & 1 \% & 0 \% & 0 \%\end{array}$

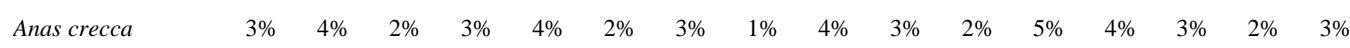

$\begin{array}{lllllllllllll}\text { Aythya ferina } & 2 \% & 2 \% & 1 \% & 2 \% & 2 \% & 1 \% & 1 \% & 1 \% & 1 \% & 1 \% & 1 \% & 1 \%\end{array}$

$\begin{array}{lllllllllllllllll}\begin{array}{l}\text { Bucephala } \\ \text { clangula }\end{array} & 0 \% & 0 \% & 0 \% & 0 \% & 1 \% & 0 \% & 0 \% & 0 \% & 0 \% & 0 \% & 0 \% & 0 \% & 0 \% & 0 \% & 0 \% & 0 \%\end{array}$

\begin{tabular}{llllllllllllllllllllll} 
Fulica atra & $12 \%$ & $10 \%$ & $4 \%$ & $10 \%$ & $5 \%$ & $7 \%$ & $5 \%$ & $3 \%$ & $3 \%$ & $4 \%$ & $3 \%$ & $5 \%$ & $6 \%$ & $4 \%$ & $6 \%$ & $5 \%$ & $7 \%$ & $1 \%$ & $2 \%$ & $2 \%$ \\
\hline
\end{tabular}

Dél-Dunántúl / Southern Transdanubia

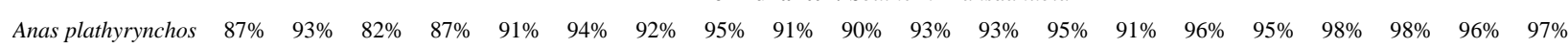

$\begin{array}{llllllllllll}\text { Anas querquedula } & 1 \% & 1 \% & 4 \% & 1 \% & 1 \% & 0 \% & 0 \% & 0 \% & 1 \% & 0 \% & 0 \%\end{array}$

$\begin{array}{llllllllllllllllll}\text { Anas crecca } & 5 \% & 1 \% & 4 \% & 4 \% & 3 \% & 2 \% & 2 \% & 2 \% & 3 \% & 5 \% & 3 \% & 4 \% & 2 \% & 6 \% & 2 \% & 2 \%\end{array}$

$\begin{array}{lllllllllllll}\text { Aythyaferina } & 1 \% & 0 \% & 1 \% & 1 \% & 1 \% & 1 \% & 1 \% & 1 \% & 1 \% & 1 \% & 0 \% & 0 \%\end{array}$

$\begin{array}{lllllllllllllllll}\begin{array}{l}\text { Bucephala } \\ \text { clangula }\end{array} & 0 \% & 0 \% & 0 \% & 0 \% & 0 \% & 0 \% & 0 \% & 0 \% & 0 \% & 0 \% & 1 \% & 0 \% & 0 \% & 0 \% & 0 \% & 0 \%\end{array}$

$\begin{array}{llllllllllllllllllllllllll}\text { Fulica atra } & 7 \% & 5 \% & 9 \% & 7 \% & 5 \% & 3 \% & 5 \% & 3 \% & 4 \% & 3 \% & 3 \% & 3 \% & 3 \% & 3 \% & 2 \% & 3 \% & 2 \% & 2 \% & 4 \% & 3 \%\end{array}$

Észak-Magyarország / Nothern Hungary

$\begin{array}{lllllllllllllllllllllllll}\text { Anas plathyrynchos } & 84 \% & 96 \% & 92 \% & 86 \% & 78 \% & 87 \% & 94 \% & 98 \% & 96 \% & 88 \% & 85 \% & 91 \% & 95 \% & 93 \% & 97 \% & 96 \% & 99 \% & 100 \% & 100 \% & 96 \%\end{array}$

$\begin{array}{llllllllllll}\text { Anas querquedula } & 1 \% & 0 \% & 1 \% & 2 \% & 1 \% & 0 \% & 1 \% & 0 \% & 0 \% & 0 \% & 2 \%\end{array}$

$\begin{array}{llllllllllllllllll}\text { Anas crecca } & 12 \% & 2 \% & 3 \% & 6 \% & 14 \% & 12 \% & 4 \% & 2 \% & 2 \% & 3 \% & 10 \% & 7 \% & 5 \% & 6 \% & 3 \% & 3 \%\end{array}$

$\begin{array}{lllllllllllll}\text { Aythyaferina } & 1 \% & 1 \% & 1 \% & 3 \% & 1 \% & 0 \% & 1 \% & 0 \% & 0 \% & 0 \% & 0 \% & 0 \%\end{array}$

$\begin{array}{llllllllllllllllll}\begin{array}{l}\text { Bucephala } \\ \text { clangula }\end{array} & 0 \% & 0 \% & 0 \% & 0 \% & 0 \% & 0 \% & 0 \% & 0 \% & 0 \% & 0 \% & 0 \% & 0 \% & 0 \% & 0 \% & 0 \% & 0 \%\end{array}$

$\begin{array}{llllllllllllllllllllllll}\text { Fulica } a \text { tra } & 1 \% & 1 \% & 3 \% & 3 \% & 6 \% & 1 \% & 1 \% & 0 \% & 2 \% & 8 \% & 3 \% & 2 \% & 1 \% & 1 \% & 0 \% & 1 \% & 1 \% & 0 \% & 0 \% & 4 \%\end{array}$

Duna-Tisza köze / Danube-Tisza Interfluve

$\begin{array}{llllllllllllllllllllll}\text { Anas plathyrynchos } & 85 \% & 84 \% & 80 \% & 83 \% & 87 \% & 83 \% & 93 \% & 89 \% & 92 \% & 89 \% & 89 \% & 92 \% & 92 \% & 92 \% & 85 \% & 93 \% & 97 \% & 98 \% & 93 \% & 95 \%\end{array}$ $\begin{array}{llllllllllll}\text { Anas querquedula } & 2 \% & 3 \% & 6 \% & 3 \% & 1 \% & 1 \% & 1 \% & 1 \% & 0 \% & 0 \% & 0 \%\end{array}$

$\begin{array}{lllllllllllllllll}\text { Anas crecca } & 8 \% & 5 \% & 6 \% & 7 \% & 5 \% & 9 \% & 3 \% & 4 \% & 2 \% & 3 \% & 4 \% & 5 \% & 4 \% & 3 \% & 6 \% & 3 \%\end{array}$

$\begin{array}{lllllllllllll}\text { Aythyaferina } & 0 \% & 2 \% & 2 \% & 2 \% & 2 \% & 2 \% & 1 \% & 1 \% & 0 \% & 1 \% & 1 \% & 0 \%\end{array}$

$\begin{array}{lllllllllllllllll}\begin{array}{l}\text { Bucephala } \\ \text { clangula }\end{array} & 0 \% & 0 \% & 1 \% & 0 \% & 0 \% & 0 \% & 0 \% & 0 \% & 0 \% & 0 \% & 0 \% & 0 \% & 0 \% & 1 \% & 0 \% & 0 \%\end{array}$

\begin{tabular}{lllllllllllllllllllllll} 
Fulica atra & $5 \%$ & $6 \%$ & $5 \%$ & $5 \%$ & $5 \%$ & $5 \%$ & $2 \%$ & $5 \%$ & $6 \%$ & $7 \%$ & $5 \%$ & $3 \%$ & $4 \%$ & $3 \%$ & $9 \%$ & $4 \%$ & $3 \%$ & $2 \%$ & $7 \%$ & $5 \%$ \\
\hline
\end{tabular}

\section{Tiszántúl / Transtisza}

$\begin{array}{llllllllllllllllllllllllllllll}\text { Anas plathyrynchos } & 83 \% & 80 \% & 73 \% & 85 \% & 87 \% & 87 \% & 89 \% & 87 \% & 89 \% & 88 \% & 86 \% & 88 \% & 91 \% & 86 \% & 91 \% & 93 \% & 98 \% & 94 \% & 96 \% & 98 \%\end{array}$ $\begin{array}{lllllllllllll}\text { Anas querquedula } & 1 \% & 1 \% & 2 \% & 1 \% & 1 \% & 1 \% & 1 \% & 1 \% & 0 \% & 0 \% & 0 \%\end{array}$

$\begin{array}{lllllllllllllllll}\text { Anas crecca } & 5 \% & 8 \% & 7 \% & 5 \% & 5 \% & 7 \% & 5 \% & 7 \% & 5 \% & 5 \% & 6 \% & 7 \% & 5 \% & 9 \% & 3 \% & 3 \%\end{array}$

$\begin{array}{llllllllllllll}\text { Aythyaferina } & 4 \% & 5 \% & 6 \% & 4 \% & 2 \% & 1 \% & 2 \% & 1 \% & 1 \% & 1 \% & 1 \% & 1 \%\end{array}$

$\begin{array}{lllllllllllllllll}\begin{array}{l}\text { Bucephala } \\ \text { clangula }\end{array} & 1 \% & 1 \% & 0 \% & 0 \% & 1 \% & 1 \% & 0 \% & 0 \% & 0 \% & 0 \% & 0 \% & 0 \% & 0 \% & 0 \% & 0 \% & 0 \%\end{array}$

$\begin{array}{lllllllllllllllllllllll}\text { Fulica atra } & 5 \% & 5 \% & 11 \% & 6 \% & 3 \% & 3 \% & 3 \% & 4 \% & 4 \% & 6 \% & 7 \% & 3 \% & 3 \% & 4 \% & 6 \% & 4 \% & 2 \% & 6 \% & 4 \% & 2 \%\end{array}$

Magyarország összesen / Hungary total

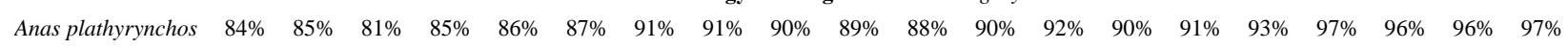

Anas querquedula $\quad 1 \% \quad 1 \% \quad 2 \% \quad 1 \% \quad 1 \% \quad 1 \% \quad 1 \% \quad 1 \% \quad 0 \% \quad 0 \% \quad 0 \%$

$\begin{array}{lllllllllllllllll}\text { Anas crecca } & 6 \% & 5 \% & 5 \% & 5 \% & 6 \% & 7 \% & 4 \% & 4 \% & 4 \% & 4 \% & 5 \% & 6 \% & 5 \% & 6 \% & 3 \% & 3 \%\end{array}$

$\begin{array}{llllllllllllll}\text { Aythyaferina } & 2 \% & 3 \% & 3 \% & 3 \% & 2 \% & 1 \% & 1 \% & 1 \% & 1 \% & 1 \% & 1 \% & 1 \%\end{array}$

$\begin{array}{lllllllllllllllll}\begin{array}{l}\text { Bucephala } \\ \text { clangula }\end{array} & 0 \% & 1 \% & 0 \% & 0 \% & 1 \% & 0 \% & 0 \% & 0 \% & 0 \% & 0 \% & 0 \% & 0 \% & 0 \% & 0 \% & 0 \% & 0 \%\end{array}$

$\begin{array}{lllllllllllllllllllllllll}\text { Fulica atra } & 6 \% & 5 \% & 8 \% & 6 \% & 4 \% & 3 \% & 3 \% & 3 \% & 4 \% & 6 \% & 6 \% & 3 \% & 4 \% & 4 \% & 6 \% & 4 \% & 3 \% & 4 \% & 4 \% & 3 \%\end{array}$ 


\section{3. melléklet: A vetési lúd becsült átlagos állománynagysága a vadászati idényben Magyarországon, 1994-2000}

Appendix 13: Average population size of Bean Goose in the hunting seasons in Hungary, 1994-2000

\begin{tabular}{|c|c|c|c|c|c|c|c|c|c|c|c|c|c|c|c|c|}
\hline $\begin{array}{l}\text { Terület, régió } \\
\text { Site, region }\end{array}$ & 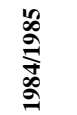 & $\begin{array}{l}\stackrel{\infty}{\circ} \\
\stackrel{2}{\approx} \\
\stackrel{\infty}{2}\end{array}$ & $\begin{array}{l}\hat{\infty} \\
\stackrel{5}{\circ} \\
\stackrel{0}{\circ}\end{array}$ & $\underset{\stackrel{\infty}{\circ}}{\stackrel{\infty}{\circ}}$ & $\begin{array}{l}\stackrel{2}{\circ} \\
\stackrel{\infty}{\circ} \\
\stackrel{\circ}{\sigma}\end{array}$ & 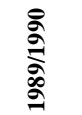 & 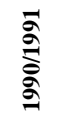 & $\underset{\sigma}{\stackrel{\sigma}{\sigma}}$ & 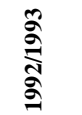 & $\underset{\sigma}{\stackrel{\Xi}{\sigma}}$ & $\frac{\stackrel{2}{\partial}}{\stackrel{2}{\sigma}}$ & 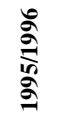 & $\frac{\hat{\sigma}}{\stackrel{\hat{\sigma}}{\circ}}$ & $\stackrel{\infty}{\stackrel{\circ}{\sigma}}$ & $\frac{\stackrel{\partial}{\sigma}}{\stackrel{\infty}{\sigma}}$ & 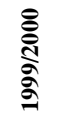 \\
\hline $\begin{array}{l}\text { Fertő-tó } \\
\text { Lake Fertő }\end{array}$ & 4150 & 4150 & 5258 & 7714 & 3324 & 3105 & 9926 & 11238 & 4956 & 8968 & 12289 & 5357 & 9921 & 5847 & 4589 & 3513 \\
\hline $\begin{array}{l}\text { Duna Gönyü-Szob } \\
\text { River Danube, Gönyü-Szob }\end{array}$ & 1125 & 3000 & 2775 & 2442 & 3337 & 3225 & 738 & 2525 & 1800 & 1215 & 2983 & 3762 & 40 & 3170 & 2975 & 1330 \\
\hline $\begin{array}{l}\text { Tatai Öreg-tó } \\
\text { Old Lake at Tata }\end{array}$ & 10000 & 15000 & 12065 & 18857 & 11285 & 3233 & 3983 & 4171 & 3865 & 2470 & 10758 & 5128 & 7349 & 10867 & 4477 & 2086 \\
\hline $\begin{array}{l}\text { Velencei-tó és Dinnyési Fertő } \\
\text { Lake Velence and Dinnyési Fertő }\end{array}$ & 17500 & 25000 & 17200 & 6750 & 13500 & 7762 & 14947 & 19725 & 11425 & 5769 & 11621 & 4550 & 5561 & 6775 & 14360 & 3850 \\
\hline $\begin{array}{l}\text { Soponyai-halastavak } \\
\text { Fishponds at Soponya }\end{array}$ & 13000 & 14000 & 22500 & 10000 & 9255 & 4375 & 7000 & 24500 & 10375 & 3450 & 5750 & 6300 & 5910 & 848 & 2500 & 2025 \\
\hline $\begin{array}{l}\text { Rétszilasi-halastavak } \\
\text { Fishponds at Rétszilas }\end{array}$ & & & & & & 142 & 22 & 63 & 875 & 158 & 1055 & 317 & 355 & 587 & 2437 & 4900 \\
\hline $\begin{array}{l}\text { Észak-Dunántúl } \\
\text { Northern Transdanubia }\end{array}$ & 45775 & 61150 & 59798 & 45763 & 40701 & 21842 & 36616 & 62222 & 33296 & 22030 & 44456 & 25414 & 29136 & 28094 & 31338 & 17704 \\
\hline $\begin{array}{l}\text { Balaton, Keszthelyi-öböl } \\
\text { Lake Balaton, Keszthelyi bay }\end{array}$ & 6500 & 7500 & 7375 & 4500 & 3112 & 312 & 525 & 4050 & 1023 & 250 & 150 & 0 & 0 & 0 & 0 & 0 \\
\hline $\begin{array}{l}\text { Kelet-Balaton } \\
\text { East-Balaton }\end{array}$ & & & & & & 1925 & 3406 & 8175 & 1887 & 3725 & 8637 & 1800 & 150 & 2050 & 6625 & 1425 \\
\hline Kis-Balaton & 35000 & 4000 & 1570 & 4125 & 3391 & 1165 & 462 & 4450 & 3725 & 14750 & 10875 & 6150 & 12500 & 7225 & 9000 & 9825 \\
\hline $\begin{array}{l}\text { Pellérdi-halastavak } \\
\text { Fishponds at Pellérd }\end{array}$ & & & 73 & 15 & 3 & 13 & 3 & 9 & 58 & 105 & 75 & 0 & 50 & 40 & 20 & 40 \\
\hline $\begin{array}{l}\text { Sumonyi-halastavak } \\
\text { Fishponds at Sumony }\end{array}$ & & & 185 & 81 & 117 & 287 & 203 & 174 & 160 & 66 & 412 & 1537 & 4175 & 662 & 5625 & 2876 \\
\hline $\begin{array}{l}\text { Dráva Barcs-Szentborbás } \\
\text { River Dráva, Barcs-Szentborbás }\end{array}$ & 1500 & 1500 & 1587 & 612 & 770 & 115 & 4425 & 75 & 0 & 0 & 0 & 0 & 0 & 0 & 0 & 0 \\
\hline $\begin{array}{l}\text { Duna, Gemenc } \\
\text { River Danube, Gemenc }\end{array}$ & 2500 & 4000 & 5625 & 7250 & 5250 & 5250 & 5000 & 5375 & 5500 & 7000 & 8750 & 6250 & 4075 & 3325 & 7825 & 5350 \\
\hline $\begin{array}{l}\text { Dél-Dunántúl } \\
\text { Southern Transdanubia }\end{array}$ & 45500 & 17000 & 16415 & 16583 & 12643 & 9067 & 14024 & 22308 & 12353 & 25896 & 28899 & 15737 & 20950 & 13302 & 29095 & 19516 \\
\hline $\begin{array}{l}\text { Tisza-tó } \\
\text { Lake Tisza }\end{array}$ & 75 & 350 & 68 & 0 & 0 & 0 & 0 & 0 & 3 & 128 & 1 & 0 & 0 & 150 & 40 & 425 \\
\hline $\begin{array}{l}\text { Észak-Magyarország } \\
\text { Nothern Hungary }\end{array}$ & 75 & 350 & 68 & 0 & 0 & 0 & 0 & 0 & 3 & 128 & 1 & 0 & 0 & 150 & 40 & 425 \\
\hline $\begin{array}{l}\text { Dunakanyar } \\
\text { Danube bend }\end{array}$ & 150 & 1500 & 361 & 268 & 1612 & 240 & 230 & 0 & 187 & 0 & 0 & 0 & 0 & 0 & 0 & 0 \\
\hline $\begin{array}{l}\text { Duna, Béda-Karapancsa } \\
\text { River Danube, Béda-Karapancsa }\end{array}$ & 3500 & 1000 & 2500 & 6500 & 4750 & 5625 & 4000 & 6000 & 4875 & 8875 & 8000 & 6000 & 6000 & 5750 & 2875 & 1312 \\
\hline $\begin{array}{l}\text { Kiskunsági szikes tavak } \\
\text { Natron lakes in Kiskunság }\end{array}$ & & & & & & 18 & 269 & 16 & 437 & 500 & 1132 & 467 & 70 & 29 & 25 & 23 \\
\hline $\begin{array}{l}\text { Duna-Tisza köze } \\
\text { Danube-Tisza Interfluve }\end{array}$ & 3650 & 2500 & 2861 & 6768 & 6362 & 5883 & 4499 & 6016 & 5499 & 9375 & 9132 & 6467 & 6070 & 5779 & 2900 & 1335 \\
\hline Hortobágy & 1500 & 150 & 263 & 288 & 526 & 265 & 237 & 383 & 353 & 1512 & 375 & 81 & 292 & 407 & 82 & 344 \\
\hline $\begin{array}{l}\text { Biharugrai és Begécsi halastavak } \\
\text { Fishponds at Biharugra and Begécs }\end{array}$ & 1500 & 650 & 310 & 284 & 2625 & 551 & 3 & 325 & 675 & 900 & 67 & 20 & 0 & 49 & 11 & 11 \\
\hline $\begin{array}{l}\text { Kardoskúti Fehér-tó } \\
\text { Lake Fehér at Kardoskút }\end{array}$ & 200 & 750 & 62 & 28 & 0 & 12 & 10 & 190 & 1133 & 199 & 254 & 94 & 11 & 3 & 0 & 7 \\
\hline $\begin{array}{l}\text { Tömörkényi Csaj-tó } \\
\text { Lake Csaj at Tömörkény }\end{array}$ & & & 4 & 1 & 6 & 14 & 2 & 0 & 196 & 18 & 121 & 1 & 3 & 6 & 23 & 2 \\
\hline $\begin{array}{l}\text { Szegedi Fehér-tó és Fertö } \\
\text { Lake Fehér and Fertö at Szeged }\end{array}$ & 1750 & 600 & 1145 & 90 & 155 & 178 & 122 & 77 & 165 & 70 & 102 & 26 & 2 & 4 & 6 & 39 \\
\hline $\begin{array}{l}\text { Tiszántúl } \\
\text { Transtisza }\end{array}$ & 4950 & 2150 & 1784 & 691 & 3312 & 1020 & 374 & 975 & 2522 & 2699 & 919 & 222 & 308 & 469 & 122 & 403 \\
\hline
\end{tabular}




\section{4. melléklet: A vetési lúd becsült átlagos állománynagysága a vadászati idényben Magyarországon, 2000-2016}

Appendix 14: Average population size of Bean Goose in the hunting seasons in Hungary, 2000-2016

\begin{tabular}{|c|c|c|c|c|c|c|c|c|c|c|c|c|c|c|c|c|}
\hline $\begin{array}{l}\text { Terület, régió } \\
\text { Site, region }\end{array}$ & 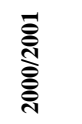 & 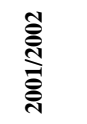 & 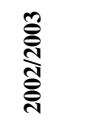 & 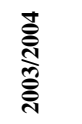 & 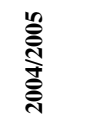 & 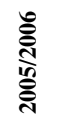 & 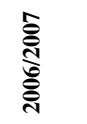 & 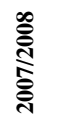 & 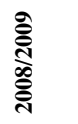 & 옿 & 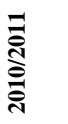 & 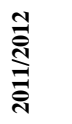 & 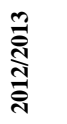 & 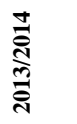 & 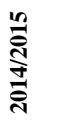 & 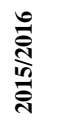 \\
\hline $\begin{array}{l}\text { Fertő-tó } \\
\text { Lake Fertö }\end{array}$ & 4293 & 1364 & 4293 & 6499 & 836 & 1809 & 2367 & 1193 & 991 & 159 & 601 & 758 & 324 & 142 & 40 & 27 \\
\hline $\begin{array}{l}\text { Duna Gönyü-Szob } \\
\text { River Danube, Gönyü-Szob }\end{array}$ & 2862 & 1738 & 205 & 421 & 679 & 3306 & 8240 & 935 & 28 & 0 & 12 & 158 & 133 & 7 & 0 & 0 \\
\hline $\begin{array}{l}\text { Tatai Öreg-tó } \\
\text { Old Lake at Tata }\end{array}$ & 5112 & 2420 & 2043 & 7793 & 3144 & 2575 & 7209 & 4463 & 5368 & 4498 & 4030 & 4120 & 1825 & 2550 & 488 & 350 \\
\hline $\begin{array}{l}\text { Velencei-tó és Dinnyési Fertő } \\
\text { Lake Velence and Dinnyési Fertö }\end{array}$ & 809 & 3175 & 2490 & 203 & 3409 & 2070 & 97 & 281 & 11 & 12 & 125 & 100 & 8 & 68 & 7 & 3 \\
\hline $\begin{array}{l}\text { Soponyai-halastavak } \\
\text { Fishponds at Soponya }\end{array}$ & 1126 & 2553 & 96 & 1514 & 750 & 277 & 206 & 613 & 1 & 56 & 0 & 16 & 1 & 4 & 1 & 1 \\
\hline $\begin{array}{l}\text { Rétszilasi-halastavak } \\
\text { Fishponds at Rétszilas }\end{array}$ & 1425 & 1245 & 1190 & 956 & 625 & 226 & 472 & 1063 & 7 & 36 & 125 & 17 & 0 & 0 & 0 & 0 \\
\hline $\begin{array}{l}\text { Észak-Dunántúl } \\
\text { Northern Transdanubia }\end{array}$ & 15627 & 12495 & 10317 & 17386 & 9442 & 10263 & 18591 & 8546 & 6406 & 4761 & 4892 & 5169 & 2291 & 2770 & 536 & 380 \\
\hline $\begin{array}{l}\text { Balaton, Keszthelyi-öböl } \\
\text { Lake Balaton, Keszthelyi bay }\end{array}$ & 0 & 0 & 0 & 0 & 0 & 0 & 0 & 0 & 0 & 0 & 0 & 0 & 0 & 0 & 0 & 0 \\
\hline $\begin{array}{l}\text { Kelet-Balaton } \\
\text { East-Balaton }\end{array}$ & 1075 & 81 & 89 & 443 & 135 & 293 & 113 & 56 & 19 & 17 & 75 & 33 & 24 & 42 & 110 & 88 \\
\hline Kis-Balaton & 6875 & 9350 & 6805 & 7218 & 6550 & 2974 & 627 & 1550 & 1675 & 853 & 137 & 452 & 33 & 57 & 56 & 220 \\
\hline $\begin{array}{l}\text { Pellérdi-halastavak } \\
\text { Fishponds at Pellérd }\end{array}$ & 4 & 0 & 0 & 1 & 3 & 50 & 0 & 0 & 15 & 0 & 0 & 0 & 0 & 0 & 0 & 0 \\
\hline $\begin{array}{l}\text { Sumonyi-halastavak } \\
\text { Fishponds at Sumony }\end{array}$ & 928 & 425 & 450 & 163 & 1638 & 56 & 441 & 7 & 0 & 118 & 18 & 75 & 83 & 57 & 0 & 25 \\
\hline $\begin{array}{l}\text { Dráva Barcs-Szentborbás } \\
\text { River Dráva, Barcs-Szentborbás }\end{array}$ & 0 & 0 & 0 & 0 & 0 & 0 & 0 & 0 & 0 & 0 & 0 & 0 & 0 & 0 & 0 & 0 \\
\hline $\begin{array}{l}\text { Duna, Gemenc } \\
\text { River Danube, Gemenc }\end{array}$ & 2750 & 3125 & 6750 & 4250 & 2875 & 6500 & 3000 & 805 & 1250 & 1050 & 1625 & 1538 & 1025 & 125 & 0 & 328 \\
\hline $\begin{array}{l}\text { Dél-Dunántúl } \\
\text { Southern Transdanubia }\end{array}$ & 11632 & 12981 & 14094 & 12075 & 11200 & 9873 & 4181 & 2419 & 2959 & 2037 & 1854 & 2098 & 1166 & 280 & 166 & 660 \\
\hline $\begin{array}{l}\text { Tisza-tó } \\
\text { Lake Tisza }\end{array}$ & 482 & 40 & 0 & 205 & 275 & 275 & 325 & 288 & 128 & 150 & 20 & 23 & 5 & 0 & 0 & 0 \\
\hline $\begin{array}{l}\text { Észak-Magyarország } \\
\text { Nothern Hungary }\end{array}$ & 482 & 40 & 0 & 205 & 275 & 275 & 325 & 288 & 128 & 150 & 20 & 23 & 5 & 0 & 0 & $\mathbf{0}$ \\
\hline $\begin{array}{l}\text { Dunakanyar } \\
\text { Danube bend }\end{array}$ & 0 & 0 & 0 & 0 & 0 & 0 & 0 & 0 & 0 & 0 & 0 & 0 & 0 & 0 & 0 & 0 \\
\hline $\begin{array}{l}\text { Duna, Béda-Karapancsa } \\
\text { River Danube, Béda-Karapancsa }\end{array}$ & 850 & 2675 & 238 & 1335 & 625 & 1218 & 358 & 403 & 322 & 1550 & 213 & 95 & 153 & 220 & 198 & 150 \\
\hline $\begin{array}{l}\text { Kiskunsági szikes tavak } \\
\text { Natron lakes in Kiskunság }\end{array}$ & 42 & 6 & 6 & 1 & 1 & 0 & 513 & 0 & 18 & 0 & 14 & 0 & 0 & 0 & 0 & 0 \\
\hline $\begin{array}{l}\text { Duna-Tisza köze } \\
\text { Danube-Tisza Interfluve }\end{array}$ & 892 & 2681 & 244 & 1336 & 626 & 1218 & 870 & 403 & 340 & 1550 & 226 & 95 & 153 & 220 & 198 & 150 \\
\hline Hortobágy & 276 & 120 & 82 & 76 & 108 & 30 & 114 & 114 & 80 & 189 & 20 & 10 & 1 & 1 & 34 & 0 \\
\hline $\begin{array}{l}\text { Biharugrai és Begécsi halastavak } \\
\text { Fishponds at Biharugra and Begécs }\end{array}$ & 0 & 0 & 14 & 11 & 15 & 1 & 9 & 4 & 0 & 1 & 1 & 0 & 0 & 0 & 1 & 0 \\
\hline $\begin{array}{l}\text { Kardoskúti Fehér-tó } \\
\text { Lake Fehér at Kardoskút }\end{array}$ & 0 & 4 & 0 & 0 & 1 & 3 & 0 & 7 & 0 & 0 & 0 & 2 & 0 & 0 & 0 & 0 \\
\hline $\begin{array}{l}\text { Tömörkényi Csaj-tó } \\
\text { Lake Csaj at Tömörkény }\end{array}$ & 7 & 9 & 0 & 0 & 11 & 1 & 0 & 0 & 0 & 0 & 3 & 0 & 0 & 0 & 0 & 0 \\
\hline $\begin{array}{l}\text { Szegedi Fehér-tó és Fertő } \\
\text { Lake Fehér and Fertö at Szeged }\end{array}$ & 7 & 2 & 0 & 0 & 0 & 1 & 0 & 0 & 0 & 0 & 6 & 0 & 0 & 0 & 0 & 0 \\
\hline $\begin{array}{l}\text { Tiszántúl } \\
\text { Transtisza }\end{array}$ & 290 & 135 & 96 & 87 & 134 & 36 & 122 & 124 & 80 & 189 & 29 & 12 & 1 & 1 & 34 & 0 \\
\hline $\begin{array}{l}\text { Magyarország összesen } \\
\text { Hungary total }\end{array}$ & 28923 & 28332 & 24751 & 31089 & 21678 & 21664 & 24089 & 11779 & 9912 & 8687 & 7022 & 7396 & 3615 & 3271 & 933 & 1190 \\
\hline
\end{tabular}




\section{5. melléklet: A nagy lilik becsült átlagos állománynagysága a vadászati idényben Magyarországon, 1994-2000}

Appendix 15: Average population size of Greater White-fronted Goose in the hunting seasons in Hungary, 1994-2000

\begin{tabular}{|c|c|c|c|c|c|c|c|c|c|c|c|c|c|c|c|c|}
\hline $\begin{array}{l}\text { Terület, régió } \\
\text { Site, region }\end{array}$ & 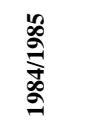 & 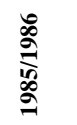 & 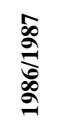 & $\underset{\stackrel{\infty}{\circ}}{\stackrel{\infty}{\circ}}$ & $\begin{array}{l}\stackrel{\circ}{\circ} \\
\stackrel{\infty}{\infty} \\
\stackrel{0}{0}\end{array}$ & 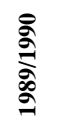 & $\begin{array}{l}\bar{\sigma} \\
\bar{\sigma}\end{array}$ & 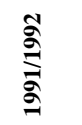 & $\underset{\sigma}{\sigma}$ & $\underset{\sigma}{\stackrel{\sigma}{\sigma}}$ & $\begin{array}{l}\stackrel{2}{\partial} \\
\text { హิ }\end{array}$ & $\stackrel{\sigma}{\sigma}_{\mathscr{\sigma}}^{\circ}$ & $\frac{\hat{\sigma}}{\widehat{\sigma}}$ & $\stackrel{\infty}{\stackrel{\alpha}{\sigma}}$ & 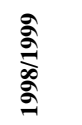 & 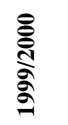 \\
\hline $\begin{array}{l}\text { Fertö-tó } \\
\text { Lake Fertő }\end{array}$ & 1250 & 100 & 765 & 407 & 1281 & 733 & 427 & 1708 & 487 & 715 & 4540 & 966 & 711 & 517 & 983 & 1882 \\
\hline $\begin{array}{l}\text { Duna Gönyü-Szob } \\
\text { River Danube, Gönyü-Szob }\end{array}$ & 0 & 0 & 2 & 0 & 0 & 0 & 25 & 0 & 75 & 5 & 345 & 157 & 0 & 62 & 322 & 162 \\
\hline $\begin{array}{l}\text { Tatai Öreg-tó } \\
\text { Old Lake at Tata }\end{array}$ & 100 & 100 & 130 & 152 & 101 & 57 & 137 & 295 & 212 & 360 & 1012 & 445 & 895 & 1100 & 641 & 750 \\
\hline $\begin{array}{l}\text { Velencei-tó és Dinnyési Fertő } \\
\text { Lake Velence and Dinnyési Fertö }\end{array}$ & 150 & 100 & 1702 & 250 & 600 & 80 & 2060 & 12250 & 1637 & 1781 & 2306 & 150 & 2342 & 3632 & 3142 & 1975 \\
\hline $\begin{array}{l}\text { Soponyai-halastavak } \\
\text { Fishponds at Soponya }\end{array}$ & 2000 & 1750 & 1875 & 625 & 450 & 125 & 137 & 2282 & 1125 & 137 & 662 & 1000 & 441 & 382 & 1037 & 551 \\
\hline $\begin{array}{l}\text { Rétszilasi-halastavak } \\
\text { Fishponds at Rétszilas }\end{array}$ & & & & & & 20 & 0 & 0 & 95 & 12 & 22 & 3 & 215 & 180 & 2625 & 3050 \\
\hline $\begin{array}{l}\text { Észak-Dunántúl } \\
\text { Northern Transdanubia }\end{array}$ & 3500 & 2050 & 4474 & 1434 & 2432 & 1015 & 2786 & 16535 & 3631 & 3010 & 8887 & 2721 & 4604 & 5873 & 8750 & 8370 \\
\hline $\begin{array}{l}\text { Balaton, Keszthelyi-öböl } \\
\text { Lake Balaton, Keszthelyi bay }\end{array}$ & 0 & 0 & 0 & 0 & 0 & 0 & 0 & 0 & 54 & 0 & 0 & 0 & 0 & 0 & 0 & 0 \\
\hline $\begin{array}{l}\text { Kelet-Balaton } \\
\text { East-Balaton }\end{array}$ & & & & & & 150 & 1250 & 2125 & 137 & 0 & 25 & 425 & 450 & 625 & 4750 & 1162 \\
\hline Kis-Balaton & 0 & 0 & 77 & 362 & 1 & 154 & 137 & 181 & 1036 & 1875 & 2875 & 3625 & 4950 & 1950 & 2000 & 3625 \\
\hline $\begin{array}{l}\text { Pellérdi-halastavak } \\
\text { Fishponds at Pellérd }\end{array}$ & & & 1 & 0 & 0 & 0 & 0 & 0 & 0 & 0 & 0 & 0 & 1 & 0 & 0 & 0 \\
\hline $\begin{array}{l}\text { Sumonyi-halastavak } \\
\text { Fishponds at Sumony }\end{array}$ & & & 1 & 1 & 0 & 0 & 1 & 0 & 1 & 0 & 1 & 1757 & 552 & 50 & 1500 & 775 \\
\hline $\begin{array}{l}\text { Dráva Barcs-Szentborbás } \\
\text { River Dráva, Barcs-Szentborbás }\end{array}$ & 250 & 150 & 0 & 0 & 0 & 0 & 0 & 0 & 0 & 0 & 0 & 0 & 0 & 0 & 0 & 0 \\
\hline $\begin{array}{l}\text { Duna, Gemenc } \\
\text { River Danube, Gemenc }\end{array}$ & 350 & 150 & 175 & 1125 & 525 & 925 & 802 & 2350 & 787 & 1875 & 2875 & 1750 & 875 & 625 & 2000 & 1600 \\
\hline $\begin{array}{l}\text { Dél-Dunántúl } \\
\text { Southern Transdanubia }\end{array}$ & 600 & 300 & 254 & 1488 & 526 & 1229 & 2190 & 4656 & 2015 & 3750 & 5776 & 7557 & 6828 & 3250 & 10250 & 7162 \\
\hline $\begin{array}{l}\text { Tisza-tó } \\
\text { Lake Tisza }\end{array}$ & 250 & 400 & 217 & 582 & 78 & 500 & 26 & 178 & 267 & 800 & 357 & 34 & 694 & 82 & 145 & 450 \\
\hline $\begin{array}{l}\text { Észak-Magyarország } \\
\text { Nothern Hungary } \\
\end{array}$ & 250 & 400 & 217 & 582 & 78 & 500 & 26 & 178 & 267 & 800 & 357 & 34 & 694 & 82 & 145 & 450 \\
\hline $\begin{array}{l}\text { Dunakanyar } \\
\text { Danube bend }\end{array}$ & 0 & 0 & 0 & 0 & 0 & 0 & 0 & 0 & 0 & 0 & 0 & 0 & 0 & 0 & 0 & 0 \\
\hline $\begin{array}{l}\text { Duna, Béda-Karapancsa } \\
\text { River Danube, Béda-Karapancsa }\end{array}$ & 650 & 50 & 175 & 1125 & 575 & 1125 & 725 & 2275 & 662 & 2225 & 2325 & 2025 & 900 & 1000 & 692 & 145 \\
\hline $\begin{array}{l}\text { Kiskunsági szikes tavak } \\
\text { Natron lakes in Kiskunság }\end{array}$ & & & & & & 200 & 2825 & 957 & 3375 & 6375 & 12878 & 1675 & 835 & 915 & 1080 & 877 \\
\hline $\begin{array}{l}\text { Duna-Tisza köze } \\
\text { Danube-Tisza Interfluve }\end{array}$ & 650 & 50 & 175 & 1125 & 575 & 1325 & 3550 & 3232 & 4037 & 8600 & 15203 & 3700 & 1735 & 1915 & 1772 & 1022 \\
\hline Hortobágy & 12500 & 1200 & 10250 & 11000 & 1696 & 13123 & 1812 & 2552 & 2075 & 2100 & 1250 & 302 & 9670 & 3014 & 3613 & 9780 \\
\hline $\begin{array}{l}\text { Biharugrai és Begécsi halastavak } \\
\text { Fishponds at Biharugra and Begécs }\end{array}$ & 1250 & 2500 & 2300 & 3187 & 2375 & 651 & 3 & 1467 & 4500 & 5625 & 2012 & 3221 & 2232 & 3500 & 4115 & 2146 \\
\hline $\begin{array}{l}\text { Kardoskúti Fehér-tó } \\
\text { Lake Fehér at Kardoskút }\end{array}$ & 10000 & 10000 & 962 & 4750 & 2062 & 474 & 762 & 3129 & 8156 & 10784 & 2904 & 2107 & 2888 & 1775 & 1043 & 891 \\
\hline $\begin{array}{l}\text { Tömörkényi Csaj-tó } \\
\text { Lake Csaj at Tömörkény }\end{array}$ & & & 488 & 312 & 597 & 272 & 267 & 186 & 1084 & 310 & 890 & 14 & 131 & 850 & 477 & 59 \\
\hline $\begin{array}{l}\text { Szegedi Fehér-tó és Fertő } \\
\text { Lake Fehér and Fertő at Szeged }\end{array}$ & 2500 & 7000 & 3487 & 1805 & 4937 & 1779 & 1003 & 4257 & 1167 & 2162 & 2162 & 496 & 428 & 706 & 558 & 624 \\
\hline $\begin{array}{l}\text { Tiszántúl } \\
\text { Transtisza }\end{array}$ & 26250 & 20700 & 17487 & 21054 & 11667 & 16299 & 3847 & 11591 & 16982 & 20981 & 9218 & 6140 & 15349 & 9845 & 9806 & 13500 \\
\hline $\begin{array}{l}\text { Magyarország összesen } \\
\text { Hungary total }\end{array}$ & 31250 & 23500 & 22607 & 25683 & 15278 & 20368 & 12399 & 36192 & 26932 & 37141 & 39441 & 20152 & 29210 & 20965 & 30723 & 30504 \\
\hline
\end{tabular}




\section{6. melléklet: A nagy lilik becsült átlagos állománynagysága a vadászati idényben Magyarországon, 2000-2016}

Appendix 16: Average population size of Greater White-fronted Goose in the hunting seasons in Hungary, 200-2016

\begin{tabular}{|c|c|c|c|c|c|c|c|c|c|c|c|c|c|c|c|c|}
\hline $\begin{array}{l}\text { Terület, régió } \\
\text { Site, region }\end{array}$ & 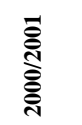 & 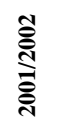 & 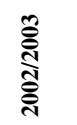 & 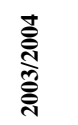 & 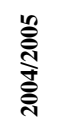 & 离 & 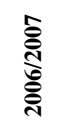 & 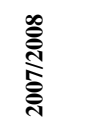 & 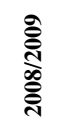 & 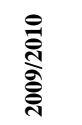 & 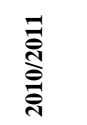 & 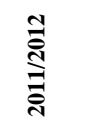 & 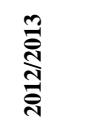 & 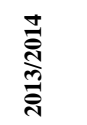 & 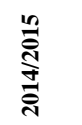 & 离 \\
\hline $\begin{array}{l}\text { Fertö-tó } \\
\text { Lake Fertö }\end{array}$ & 2828 & 182 & 1563 & 6161 & 3325 & 2968 & 7884 & 6259 & 6971 & 2286 & 4584 & 10917 & 20021 & 7954 & 4078 & 7591 \\
\hline $\begin{array}{l}\text { Duna Gönyü-Szob } \\
\text { River Danube, Gönyü-Szob }\end{array}$ & 960 & 336 & 38 & 56 & 58 & 965 & 2627 & 88 & 18 & 0 & 1 & 72 & 1413 & 30 & 0 & 0 \\
\hline $\begin{array}{l}\text { Tatai Öreg-tó } \\
\text { Old Lake at Tata }\end{array}$ & 4705 & 262 & 215 & 4179 & 1698 & 2800 & 6538 & 6875 & 13150 & 11998 & 10314 & 15701 & 14700 & 19925 & 9475 & 5625 \\
\hline $\begin{array}{l}\text { Velencei-tó és Dinnyési Fertő } \\
\text { Lake Velence and Dinnyési Fertő }\end{array}$ & 9975 & 830 & 2085 & 1768 & 4640 & 9720 & 10550 & 6215 & 17425 & 8698 & 15288 & 18758 & 10315 & 22075 & 4442 & 3003 \\
\hline $\begin{array}{l}\text { Soponyai-halastavak } \\
\text { Fishponds at Soponya }\end{array}$ & 2131 & 2884 & 53 & 2263 & 1634 & 2446 & 2144 & 4164 & 1788 & 4370 & 938 & 6356 & 3758 & 2238 & 3960 & 4243 \\
\hline $\begin{array}{l}\text { Rétszilasi-halastavak } \\
\text { Fishponds at Rétszilas }\end{array}$ & 4925 & 1649 & 1670 & 2308 & 2901 & 3500 & 3308 & 2638 & 5970 & 3374 & 4034 & 4903 & 6037 & 3213 & 441 & 4550 \\
\hline $\begin{array}{l}\text { Észak-Dunántúl } \\
\text { Northern Transdanubia }\end{array}$ & 25524 & 6143 & 5624 & 16735 & 14256 & 22399 & 33050 & 26238 & 45321 & 30725 & 35159 & 56707 & 56244 & 55434 & 22395 & 25012 \\
\hline $\begin{array}{l}\text { Balaton, Keszthelyi-öböl } \\
\text { Lake Balaton, Keszthelyi bay }\end{array}$ & 0 & 0 & 0 & 0 & 0 & 0 & 0 & 0 & 0 & 0 & 0 & 0 & 0 & 0 & 0 & 0 \\
\hline $\begin{array}{l}\text { Kelet-Balaton } \\
\text { East-Balaton }\end{array}$ & 650 & 15 & 24 & 51 & 38 & 126 & 158 & 128 & 168 & 125 & 161 & 113 & 162 & 253 & 300 & 325 \\
\hline Kis-Balaton & 3250 & 3650 & 2053 & 2075 & 3668 & 1853 & 2109 & 975 & 1550 & 1265 & 1862 & 1812 & 4252 & 1712 & 2462 & 1523 \\
\hline $\begin{array}{l}\text { Pellérdi-halastavak } \\
\text { Fishponds at Pellérd }\end{array}$ & 0 & 0 & 0 & 0 & 0 & 13 & 0 & 0 & 0 & 2 & 0 & 0 & 0 & 0 & 0 & 0 \\
\hline $\begin{array}{l}\text { Sumonyi-halastavak } \\
\text { Fishponds at Sumony }\end{array}$ & 16 & 4 & 5 & 12 & 24 & 88 & 263 & 4 & 8 & 45 & 150 & 150 & 320 & 750 & 113 & 46 \\
\hline $\begin{array}{l}\text { Dráva Barcs-Szentborbás } \\
\text { River Dráva, Barcs-Szentborbás }\end{array}$ & 0 & 0 & 0 & 0 & 0 & 0 & 0 & 0 & 0 & 0 & 0 & 0 & 0 & 0 & 0 & 0 \\
\hline $\begin{array}{l}\text { Duna, Gemenc } \\
\text { River Danube, Gemenc }\end{array}$ & 800 & 1075 & 8125 & 3875 & 1400 & 2375 & 3125 & 445 & 1550 & 150 & 200 & 175 & 100 & 1500 & 225 & 673 \\
\hline $\begin{array}{l}\text { Dél-Dunántúl } \\
\text { Southern Transdanubia }\end{array}$ & 4716 & 4744 & 10207 & 6013 & 5129 & 4454 & 5654 & 1552 & 3276 & 1587 & 2373 & 2249 & 4834 & 4214 & 3099 & 2566 \\
\hline $\begin{array}{l}\text { Tisza-tó } \\
\text { Lake Tisza }\end{array}$ & 187 & 145 & 718 & 2950 & 3500 & 7000 & 1800 & 1750 & 1125 & 1055 & 363 & 500 & 300 & 425 & 2300 & 1225 \\
\hline $\begin{array}{l}\text { Észak-Magyarország } \\
\text { Nothern Hungary }\end{array}$ & 187 & 145 & 718 & 2950 & 3500 & 7000 & 1800 & 1750 & 1125 & 1055 & 363 & 500 & 300 & 425 & 2300 & 1225 \\
\hline $\begin{array}{l}\text { Dunakanyar } \\
\text { Danube bend }\end{array}$ & 0 & 0 & 0 & 0 & 0 & 0 & 0 & 0 & 0 & 0 & 0 & 0 & 0 & 0 & 0 & 0 \\
\hline $\begin{array}{l}\text { Duna, Béda-Karapancsa } \\
\text { River Danube, Béda-Karapancsa }\end{array}$ & 375 & 2762 & 35 & 145 & 0 & 963 & 54 & 60 & 99 & 1825 & 0 & 33 & 45 & 190 & 135 & 4875 \\
\hline $\begin{array}{l}\text { Kiskunsági szikes tavak } \\
\text { Natron lakes in Kiskunság }\end{array}$ & 3736 & 1038 & 902 & 1311 & 2208 & 7470 & 1973 & 119 & 3725 & 3248 & 5291 & 6994 & 5663 & 5862 & 2760 & 634 \\
\hline $\begin{array}{l}\text { Duna-Tisza köze } \\
\text { Danube-Tisza Interfluve }\end{array}$ & 4111 & 3800 & 937 & 1456 & 2208 & 8433 & 2026 & 179 & 3824 & 5073 & 5291 & 7026 & 5708 & 6052 & 2895 & 5509 \\
\hline Hortobágy & 8633 & 7626 & 3553 & 14314 & 9141 & 10751 & 2934 & 3930 & 4082 & 41076 & 21784 & 14632 & 15630 & 13951 & 16251 & 19319 \\
\hline $\begin{array}{l}\text { Biharugrai és Begécsi halastavak } \\
\text { Fishponds at Biharugra and Begécs }\end{array}$ & 4488 & 2182 & 4256 & 3055 & 8955 & 4230 & 5236 & 19311 & 7820 & 12552 & 18303 & 14441 & 14178 & 13896 & 18163 & 9935 \\
\hline $\begin{array}{l}\text { Kardoskúti Fehér-tó } \\
\text { Lake Fehér at Kardoskút }\end{array}$ & 106 & 1250 & 0 & 1010 & 1788 & 2058 & 2550 & 1460 & 2353 & 5375 & 2750 & 395 & 2625 & 2131 & 2254 & 5125 \\
\hline $\begin{array}{l}\text { Tömörkényi Csaj-tó } \\
\text { Lake Csaj at Tömörkény }\end{array}$ & 1417 & 839 & 436 & 16 & 3375 & 513 & 1376 & 195 & 1650 & 992 & 1218 & 4168 & 1142 & 1810 & 1475 & 875 \\
\hline $\begin{array}{l}\text { Szegedi Fehér-tó és Fertő } \\
\text { Lake Fehér and Fertő at Szeged }\end{array}$ & 2598 & 235 & 280 & 65 & 170 & 154 & 0 & 503 & 263 & 626 & 2576 & 6046 & 438 & 82 & 471 & 397 \\
\hline $\begin{array}{l}\text { Tiszántúl } \\
\text { Transtisza }\end{array}$ & 17242 & 12132 & 8525 & 18460 & 23428 & 17705 & 12096 & 25399 & 16167 & 60620 & 46630 & 39682 & 34013 & 31869 & 38614 & 35651 \\
\hline $\begin{array}{l}\text { Magyarország összesen } \\
\text { Hungary total }\end{array}$ & 51780 & 26964 & 26011 & 45614 & 48520 & 59990 & 54626 & 55117 & 69712 & 99060 & 89814 & 106163 & 101098 & 97994 & 69303 & 69963 \\
\hline
\end{tabular}




\section{7. melléklet: A tőkés réce becsült átlagos állománynagysága a vadászati idényben} Magyarországon, 1996-2016

Appendix 17: Average population size of Mallard in the hunting seasons in Hungary, 1996-2016

\begin{tabular}{|c|c|c|c|c|c|c|c|c|c|c|c|c|c|c|c|c|c|c|c|c|}
\hline $\begin{array}{l}\text { Terület, régió } \\
\text { Site, region }\end{array}$ & ڤે & 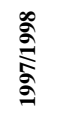 & $\underset{\partial}{\stackrel{\partial}{\partial े}}$ & 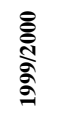 & 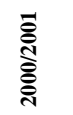 & 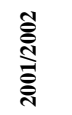 & 气ิેัญ & 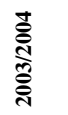 & 言 & ڤัڤ & 䒽 & 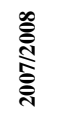 & 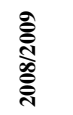 & 옳 & ฮิ & בัป & 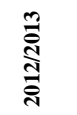 & 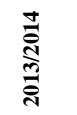 & 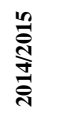 & 啇 \\
\hline $\begin{array}{l}\text { Fertő-tó } \\
\text { Lake Fertő }\end{array}$ & 62 & 1680 & 189 & 301 & 446 & 76 & 297 & 401 & 777 & 403 & 556 & 768 & 378 & 378 & 253 & 652 & 1871 & 660 & 1676 & 1620 \\
\hline $\begin{array}{l}\text { Duna Gönyü-Szob } \\
\text { River Danube, Gönyü-Szob }\end{array}$ & 2874 & 2693 & 2385 & 7450 & 6417 & 6940 & 1734 & 2625 & 3738 & 4674 & 1894 & 4926 & 6031 & 3715 & 5211 & 4528 & 3060 & 1572 & 2952 & 4432 \\
\hline $\begin{array}{l}\text { Tatai Öreg-tó } \\
\text { Old Lake at Tata }\end{array}$ & 1950 & 2825 & 1733 & 2877 & 2305 & 1278 & 362 & 422 & 586 & 364 & 574 & 728 & 2481 & 820 & 644 & 662 & 2988 & 1637 & 740 & 1116 \\
\hline Dinnyési Fertő & 594 & 1830 & 1245 & 448 & 3350 & 985 & 709 & 174 & 455 & 570 & 1243 & 299 & 375 & 72 & 1346 & 1191 & 361 & 2690 & 1169 & 430 \\
\hline $\begin{array}{l}\text { Velencei-tó } \\
\text { Lake Velence }\end{array}$ & 529 & 1900 & 1040 & 103 & 255 & 360 & 287 & 54 & 169 & 280 & 164 & 136 & 886 & 560 & 102 & 320 & 570 & 1245 & 194 & 153 \\
\hline $\begin{array}{l}\text { Soponyai-halastavak } \\
\text { Fishponds at Soponya }\end{array}$ & 380 & 1808 & 1295 & 1493 & 3651 & 1151 & 909 & 828 & 1492 & 1296 & 1000 & 2045 & 1173 & 730 & 340 & 1419 & 1682 & 1286 & 643 & 1671 \\
\hline $\begin{array}{l}\text { Rétszilasi-halastavak } \\
\text { Fishponds at Rétszilas }\end{array}$ & 347 & 1974 & 1780 & 3180 & 4873 & 5361 & 6327 & 1139 & 2891 & 1656 & 1857 & 2185 & 1828 & 1305 & 446 & 1507 & 1532 & 1208 & 849 & 1163 \\
\hline $\begin{array}{l}\text { Dunakanyar } \\
\text { Danube bend }\end{array}$ & 1123 & 1522 & 1702 & 1579 & 2411 & 2122 & 1822 & 2180 & 2849 & 3700 & 3141 & 1887 & 2446 & 1681 & 586 & 2682 & 1827 & 1634 & 900 & 1246 \\
\hline $\begin{array}{l}\text { Észak-Dunántúl } \\
\text { Northern Transdanubia }\end{array}$ & 7859 & 16232 & 11369 & 17431 & 23708 & 18273 & 12447 & 7823 & 12956 & 12943 & 10429 & 12974 & 15599 & 9260 & 8926 & 12961 & 13891 & 11931 & 9122 & 11831 \\
\hline $\begin{array}{l}\text { Balaton, Keszthelyi-öböl } \\
\text { Lake Balaton, Keszthelyi bay }\end{array}$ & 257 & 525 & 407 & 223 & 263 & 188 & 184 & 69 & 274 & 119 & 88 & 112 & 85 & 325 & 214 & 238 & 575 & 252 & 396 & 360 \\
\hline Kis-Balaton & 4600 & 5353 & 2633 & 5513 & 1638 & 4152 & 2799 & 1145 & 2290 & 1601 & 620 & 508 & 329 & 436 & 735 & 1174 & 1181 & 842 & 1292 & 885 \\
\hline $\begin{array}{l}\text { Dráva Barcs-Szentborbás } \\
\text { River Dráva, Barcs- } \\
\text { Szentborbás }\end{array}$ & 1135 & 1132 & 3245 & 3316 & 0 & 0 & 1266 & 1605 & 700 & 614 & 133 & 1069 & 27 & 38 & 200 & 149 & 78 & 91 & 341 & 477 \\
\hline $\begin{array}{l}\text { Gyékényesi-kavicsbányató } \\
\text { Gravel pit at Gyékényes }\end{array}$ & 561 & 951 & 1361 & 443 & 773 & 554 & 641 & 429 & 1615 & 2561 & 672 & 4245 & 1184 & 968 & 1590 & 734 & 1125 & 967 & 692 & 833 \\
\hline $\begin{array}{l}\text { Sumonyi-halastavak } \\
\text { Fishponds at Sumony }\end{array}$ & 1875 & 1175 & 1725 & 3800 & 1925 & 1142 & 927 & 540 & 875 & 762 & 667 & 775 & 339 & 750 & 275 & 355 & 603 & 667 & 377 & 760 \\
\hline $\begin{array}{l}\text { Pellérdi-halastavak } \\
\text { Fishponds at Pellérd }\end{array}$ & 14 & 4 & 500 & 97 & 29 & 17 & 16 & 197 & 59 & 30 & 164 & 41 & 37 & 175 & 121 & 154 & 550 & 88 & 253 & 61 \\
\hline $\begin{array}{l}\text { Dél-Dunántúl } \\
\text { Southern Transdanubia }\end{array}$ & 8442 & 9140 & 9871 & 13392 & 4628 & 6053 & 5833 & 3985 & 5812 & 5687 & 2344 & 6751 & 2001 & 2691 & 3134 & 2804 & 4112 & 2905 & 3351 & 3376 \\
\hline $\begin{array}{l}\text { Duna Baja-országhatár } \\
\text { River Danube, Baja-state } \\
\text { border }\end{array}$ & 4245 & 4238 & 5458 & 8125 & 4905 & 4938 & 2154 & 4392 & 5491 & 7957 & 6599 & 5633 & 5689 & 4468 & 4470 & 4650 & 2144 & 4687 & 2277 & 5855 \\
\hline $\begin{array}{l}\text { Kiskunsági szikes tavak } \\
\text { Natron lakes in Kiskunság }\end{array}$ & 3345 & 564 & 451 & 3115 & 658 & 1571 & 472 & 674 & 1066 & 823 & 1114 & 283 & 104 & 1070 & 1094 & 3848 & 253 & 1157 & 1504 & 1314 \\
\hline $\begin{array}{l}\text { Duna-Tisza köze } \\
\text { Danube-Tisza Interfluve }\end{array}$ & 7590 & 4802 & 5909 & 11240 & 5563 & 6509 & 2626 & 5066 & 6557 & 8780 & 7713 & 5917 & 5793 & 5538 & 5564 & 8499 & 2398 & 5844 & 3781 & 7168 \\
\hline Hortobágy I. & 7113 & 4073 & 3552 & 8388 & 6870 & 3185 & 6015 & 5281 & 4008 & 4311 & 3872 & 4256 & 3322 & 4779 & 4029 & 7225 & 4419 & 5430 & 6579 & 7384 \\
\hline Hortobágy II. & 2963 & 1322 & 1311 & 3507 & 2833 & 4445 & 1427 & 1665 & 730 & 1027 & 542 & 328 & 962 & 469 & 572 & 310 & 250 & 474 & 843 & 699 \\
\hline Hortobágy III. & 2660 & 4382 & 1133 & 2807 & 7687 & 4669 & 4655 & 1262 & 10180 & 4777 & 1979 & 1529 & 2177 & 5853 & 1254 & 3491 & 3035 & 4633 & 3678 & 2935 \\
\hline $\begin{array}{l}\text { Kardoskúti Fehér-tó } \\
\text { Lake Fehér at Kardoskút }\end{array}$ & 3190 & 980 & 863 & 2250 & 11 & 500 & 363 & 36 & 305 & 1207 & 2912 & 372 & 287 & 903 & 354 & 325 & 310 & 24 & 343 & 455 \\
\hline $\begin{array}{l}\text { Biharugrai és Begécsi } \\
\text { halastavak } \\
\text { Fishponds at Biharugra and } \\
\text { Begécs }\end{array}$ & 19496 & 14090 & 21005 & 24122 & 9425 & 10784 & 11921 & 9558 & 22232 & 20995 & 16465 & 13096 & 3786 & 8592 & 12763 & 7363 & 4188 & 12105 & 9677 & 10517 \\
\hline $\begin{array}{l}\text { Tömörkényi Csaj-tó } \\
\text { Lake Csaj at Tömörkény }\end{array}$ & 2298 & 1672 & 1698 & 4446 & 2530 & 2723 & 1476 & 877 & 551 & 973 & 875 & 778 & 1237 & 2945 & 234 & 1555 & 915 & 1805 & 1648 & 1750 \\
\hline $\begin{array}{l}\text { Szegedi Fehér-tó és Fertő } \\
\text { Lake Fehér and Fertö at Szeged }\end{array}$ & 819 & 2501 & 1820 & 5249 & 3463 & 1177 & 1993 & 679 & 1674 & 1478 & 1585 & 770 & 638 & 1183 & 986 & 1370 & 1607 & 1461 & 1173 & 1251 \\
\hline $\begin{array}{l}\text { Tiszántúl } \\
\text { Transtisza }\end{array}$ & 38539 & 29020 & 31382 & 50769 & 32819 & 27483 & 27850 & 19358 & 39679 & 34768 & 28229 & 21128 & 12409 & 24723 & 20192 & 21640 & 14724 & 25931 & 23942 & 24990 \\
\hline $\begin{array}{l}\text { Magyarország összesen } \\
\text { Hungary total }\end{array}$ & 2430 & 59194 & 58531 & 92832 & 66718 & 58318 & 48756 & 36232 & 65004 & 62178 & 48715 & 46769 & 35802 & 42212 & 37816 & 45903 & 35124 & 46611 & 40195 & 47365 \\
\hline
\end{tabular}




\section{8. melléklet: A csörgő réce becsült átlagos állománynagysága a vadászati idényben Magyarországon, 1996-2012}

Appendix 18: Average population size of Eurasian Teal in the hunting seasons in Hungary, 1996-2012

\begin{tabular}{|c|c|c|c|c|c|c|c|c|c|c|c|c|c|c|c|c|}
\hline $\begin{array}{l}\text { Terület, régió } \\
\text { Site, region }\end{array}$ & $\begin{array}{l}\hat{\sigma} \\
\stackrel{\sigma}{\sigma}\end{array}$ & $\stackrel{\infty}{\stackrel{\circ}{\sigma}}$ & $\begin{array}{l}\stackrel{\partial}{\sigma} \\
\stackrel{\partial}{\circ}\end{array}$ & $\begin{array}{l}\text { ్ㅗㅇ } \\
\text { 亏ે }\end{array}$ & 突 & 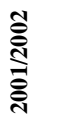 & 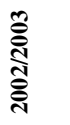 & 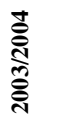 & 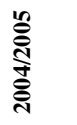 & 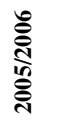 & 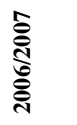 & 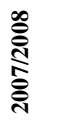 & 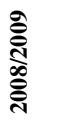 & 옿 & $\begin{array}{l}\overline{\bar{\Xi}} \\
\overline{\bar{\Xi}}\end{array}$ & 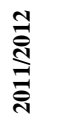 \\
\hline $\begin{array}{l}\text { Fertő-tó } \\
\text { Lake Fertö }\end{array}$ & 1280 & 2523 & 3051 & 2019 & 2715 & 882 & 1529 & 1714 & 1599 & 1189 & 1207 & 3126 & 1258 & 626 & 588 & 1277 \\
\hline $\begin{array}{l}\text { Duna Gönyü-Szob } \\
\text { River Danube, Gönyü-Szob }\end{array}$ & 0 & 6 & 0 & 5 & 4 & 3 & 0 & 1 & 6 & 1 & 0 & 0 & 0 & 0 & 10 & 12 \\
\hline $\begin{array}{l}\text { Tatai Öreg-tó } \\
\text { Old Lake at Tata }\end{array}$ & 297 & 439 & 343 & 168 & 370 & 122 & 59 & 110 & 113 & 268 & 153 & 226 & 333 & 160 & 203 & 232 \\
\hline Dinnyési Fertő & 80 & 155 & 167 & 86 & 385 & 105 & 97 & 20 & 128 & 84 & 71 & 113 & 129 & 4 & 40 & 85 \\
\hline $\begin{array}{l}\text { Velencei-tó } \\
\text { Lake Velence }\end{array}$ & 45 & 78 & 31 & 0 & 11 & 12 & 28 & 3 & 21 & 7 & 13 & 12 & 2 & 2 & 0 & 6 \\
\hline $\begin{array}{l}\text { Soponyai-halastavak } \\
\text { Fishponds at Soponya }\end{array}$ & 10 & 7 & 39 & 215 & 32 & 223 & 46 & 35 & 4 & 188 & 82 & 34 & 7 & 76 & 14 & 63 \\
\hline $\begin{array}{l}\text { Rétszilasi-halastavak } \\
\text { Fishponds at Rétszilas }\end{array}$ & 25 & 45 & 18 & 183 & 61 & 67 & 18 & 22 & 11 & 211 & 103 & 172 & 247 & 109 & 115 & 182 \\
\hline $\begin{array}{l}\text { Dunakanyar } \\
\text { Danube bend }\end{array}$ & 7 & 24 & 9 & 37 & 172 & 7 & 2 & 7 & 14 & 14 & 8 & 8 & 2 & 6 & 0 & 9 \\
\hline $\begin{array}{l}\text { Észak-Dunántúl } \\
\text { Northern Transdanubia }\end{array}$ & 1744 & 3277 & 3658 & 2713 & 3750 & 1421 & 1779 & 1912 & 1895 & 1960 & 1636 & 3690 & 1977 & 981 & 969 & 1866 \\
\hline $\begin{array}{l}\text { Balaton, Keszthelyi-öböl } \\
\text { Lake Balaton, Keszthelyi bay }\end{array}$ & 0 & 0 & 0 & 0 & 0 & 0 & 0 & 0 & 0 & 0 & 0 & 0 & 0 & 0 & 2 & 0 \\
\hline Kis-Balaton & 30 & 294 & 138 & 947 & 783 & 1148 & 967 & 897 & 153 & 82 & 1987 & 24 & 82 & 359 & 2 & 234 \\
\hline $\begin{array}{l}\text { Dráva Barcs-Szentborbás } \\
\text { River Dráva, Barcs-Szentborbás }\end{array}$ & 113 & 57 & 243 & 398 & 1 & 0 & 11 & 73 & 0 & 2 & 0 & 1 & 0 & 0 & 0 & 7 \\
\hline $\begin{array}{l}\text { Gyékényesi-kavicsbányató } \\
\text { Gravel pit at Gyékényes }\end{array}$ & 0 & 0 & 18 & 10 & 500 & 1 & 1 & 2 & 27 & 56 & 14 & 383 & 129 & 18 & 182 & 8 \\
\hline $\begin{array}{l}\text { Sumonyi-halastavak } \\
\text { Fishponds at Sumony }\end{array}$ & 550 & 118 & 438 & 558 & 1 & 268 & 174 & 20 & 190 & 55 & 193 & 188 & 102 & 275 & 8 & 88 \\
\hline $\begin{array}{l}\text { Pellérdi-halastavak } \\
\text { Fishponds at Pellérd }\end{array}$ & 0 & 1 & 13 & 2 & 14 & 0 & 5 & 35 & 0 & 1 & 38 & 16 & 0 & 13 & 4 & 22 \\
\hline $\begin{array}{l}\text { Dél-Dunántúl } \\
\text { Southern Transdanubia }\end{array}$ & 693 & 470 & 850 & 1915 & 1299 & 1417 & 1158 & 1027 & 370 & 196 & 2232 & 610 & 313 & 665 & 197 & 358 \\
\hline $\begin{array}{l}\text { Duna Baja-országhatár } \\
\text { River Danube, Baja-state border }\end{array}$ & 44 & 86 & 50 & 45 & 172 & 37 & 5 & 48 & 94 & 151 & 46 & 40 & 75 & 23 & 43 & 23 \\
\hline $\begin{array}{l}\text { Kiskunsági szikes tavak } \\
\text { Natron lakes in Kiskunság }\end{array}$ & 1393 & 373 & 1300 & 3008 & 993 & 1512 & 117 & 313 & 628 & 859 & 435 & 203 & 122 & 305 & 2545 & 452 \\
\hline $\begin{array}{l}\text { Duna-Tisza köze } \\
\text { Danube-Tisza Interfluve }\end{array}$ & 1437 & 459 & 1350 & 3053 & 1165 & 1549 & 122 & 361 & 721 & 1010 & 481 & 243 & 197 & 328 & 2588 & 474 \\
\hline Hortobágy I. & 6150 & 1247 & 991 & 2529 & 993 & 1355 & 1402 & 1264 & 2695 & 3208 & 2505 & 1535 & 1645 & 2351 & 2449 & 1668 \\
\hline Hortobágy II. & 2174 & 41 & 405 & 1073 & 1483 & 1003 & 683 & 780 & 457 & 1691 & 1199 & 60 & 208 & 481 & 2865 & 189 \\
\hline Hortobágy III. & 391 & 409 & 398 & 598 & 371 & 266 & 266 & 237 & 326 & 389 & 40 & 186 & 368 & 271 & 229 & 331 \\
\hline $\begin{array}{l}\text { Kardoskúti Fehér-tó } \\
\text { Lake Fehér at Kardoskút }\end{array}$ & 1100 & 84 & 138 & 188 & 0 & 108 & 30 & 5 & 621 & 249 & 77 & 111 & 12 & 40 & 398 & 0 \\
\hline $\begin{array}{l}\text { Biharugrai és Begécsi halastavak } \\
\text { Fishponds at Biharugra and } \\
\text { Begécs }\end{array}$ & 1565 & 909 & 1898 & 1430 & 1640 & 1312 & 910 & 496 & 3328 & 1902 & 2371 & 1004 & 1190 & 1181 & 1458 & 387 \\
\hline $\begin{array}{l}\text { Tömörkényi Csaj-tó } \\
\text { Lake Csaj at Tömörkény }\end{array}$ & 665 & 535 & 144 & 894 & 869 & 812 & 245 & 663 & 219 & 208 & 255 & 230 & 82 & 964 & 17 & 220 \\
\hline $\begin{array}{l}\text { Szegedi Fehér-tó és Fertő } \\
\text { Lake Fehér and Fertö at Szeged }\end{array}$ & 278 & 340 & 635 & 1668 & 686 & 441 & 134 & 44 & 117 & 202 & 158 & 219 & 283 & 109 & 28 & 346 \\
\hline $\begin{array}{l}\text { Tiszántúl } \\
\text { Transtisza }\end{array}$ & 12323 & 3565 & 4609 & 8380 & 6042 & 5297 & 3670 & 3489 & 7763 & 7848 & 6605 & 3344 & 3788 & 5396 & 7441 & 3139 \\
\hline $\begin{array}{l}\text { Magyarország összesen } \\
\text { Hungary total }\end{array}$ & 16197 & 7771 & 10467 & 16061 & 12256 & 9684 & 6729 & 6789 & 10749 & 11013 & 10953 & 7887 & 6274 & $\mathbf{7 3 7 0}$ & 11195 & 5836 \\
\hline
\end{tabular}




\section{9. melléklet: A böjti réce becsült átlagos állománynagysága a vadászati idényben Magyarországon, 1996-2007}

Appendix 19: Average population size of Garganey in the hunting seasons in Hungary, 1996-2007

\begin{tabular}{|c|c|c|c|c|c|c|c|c|c|c|c|}
\hline $\begin{array}{l}\text { Terület, régió } \\
\text { Site, region }\end{array}$ & $\begin{array}{l}\hat{\sigma} \\
\frac{\sigma}{\delta} \\
\sigma\end{array}$ & $\stackrel{\infty}{\stackrel{\alpha}{\sigma}}$ & 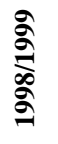 & 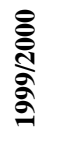 & 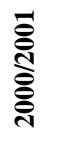 & 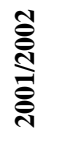 & 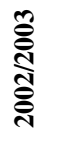 & 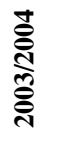 & 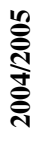 & 怘 & 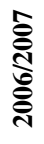 \\
\hline $\begin{array}{l}\text { Fertő-tó } \\
\text { Lake Fertő }\end{array}$ & 0 & 0 & 235 & 0 & 30 & 50 & 5 & 5 & 0 & 1 & 0 \\
\hline $\begin{array}{l}\text { Duna Gönyü-Szob } \\
\text { River Danube, Gönyü-Szob }\end{array}$ & 0 & 0 & 0 & 0 & 0 & 0 & 0 & 0 & 0 & 0 & 0 \\
\hline $\begin{array}{l}\text { Tatai Öreg-tó } \\
\text { Old Lake at Tata }\end{array}$ & 0 & 0 & 19 & 1 & 0 & 0 & 0 & 0 & 0 & 0 & 0 \\
\hline Dinnyési Fertő & 0 & 28 & 22 & 48 & 0 & 17 & 3 & 3 & 2 & 0 & 0 \\
\hline $\begin{array}{l}\text { Velencei-tó } \\
\text { Lake Velence }\end{array}$ & 0 & 14 & 3 & 11 & 0 & 4 & 0 & 0 & 0 & 0 & 0 \\
\hline $\begin{array}{l}\text { Soponyai-halastavak } \\
\text { Fishponds at Soponya }\end{array}$ & 0 & 38 & 150 & 152 & 16 & 144 & 38 & 33 & 0 & 0 & 20 \\
\hline $\begin{array}{l}\text { Rétszilasi-halastavak } \\
\text { Fishponds at Rétszilas }\end{array}$ & 0 & 0 & 0 & 0 & 30 & 26 & 17 & 5 & 0 & 0 & 1 \\
\hline $\begin{array}{l}\text { Dunakanyar } \\
\text { Danube bend }\end{array}$ & 0 & 0 & 1 & 0 & 0 & 0 & 0 & 0 & 0 & 0 & 0 \\
\hline $\begin{array}{l}\text { Észak-Dunántúl } \\
\text { Northern Transdanubia }\end{array}$ & $\mathbf{0}$ & 80 & 430 & 212 & 76 & 241 & 63 & 46 & 2 & 1 & 21 \\
\hline $\begin{array}{l}\text { Balaton, Keszthelyi-öböl } \\
\text { Lake Balaton, Keszthelyi bay }\end{array}$ & 0 & 0 & 0 & 0 & 0 & 0 & 1 & 0 & 0 & 0 & 0 \\
\hline Kis-Balaton & 0 & 12 & 70 & 0 & 77 & 18 & 13 & 17 & 0 & 0 & 0 \\
\hline $\begin{array}{l}\text { Dráva Barcs-Szentborbás } \\
\text { River Dráva, Barcs-Szentborbás }\end{array}$ & 0 & 0 & 0 & 0 & 0 & 0 & 0 & 0 & 0 & 0 & 0 \\
\hline $\begin{array}{l}\text { Gyékényesi-kavicsbányató } \\
\text { Gravel pit at Gyékényes }\end{array}$ & 0 & 0 & 0 & 0 & 0 & 0 & 0 & 0 & 0 & 0 & 0 \\
\hline $\begin{array}{l}\text { Sumonyi-halastavak } \\
\text { Fishponds at Sumony }\end{array}$ & 0 & 0 & 0 & 0 & 1 & 4 & 1 & 0 & 0 & 0 & 0 \\
\hline $\begin{array}{l}\text { Pellérdi-halastavak } \\
\text { Fishponds at Pellérd }\end{array}$ & 0 & 0 & 1 & 0 & 0 & 5 & 0 & 0 & 0 & 0 & 0 \\
\hline $\begin{array}{l}\text { Dél-Dunántúl } \\
\text { Southern Transdanubia }\end{array}$ & 0 & 12 & 71 & $\mathbf{0}$ & 78 & 27 & 15 & 17 & $\mathbf{0}$ & 0 & $\mathbf{0}$ \\
\hline $\begin{array}{l}\text { Duna Baja-országhatár } \\
\text { River Danube, Baja-state border }\end{array}$ & 0 & 0 & 0 & 0 & 0 & 0 & 0 & 0 & 0 & 0 & 0 \\
\hline $\begin{array}{l}\text { Kiskunsági szikes tavak } \\
\text { Natron lakes in Kiskunság }\end{array}$ & 0 & 0 & 170 & 68 & 15 & 7 & 0 & 0 & 0 & 0 & 1 \\
\hline $\begin{array}{l}\text { Duna-Tisza köze } \\
\text { Danube-Tisza Interfluve }\end{array}$ & $\mathbf{0}$ & $\mathbf{0}$ & 170 & 68 & 15 & 7 & $\mathbf{0}$ & $\mathbf{0}$ & $\mathbf{0}$ & 0 & 1 \\
\hline Hortobágy I. & 0 & 46 & 86 & 66 & 1 & 29 & 16 & 50 & 0 & 50 & 8 \\
\hline Hortobágy II. & 0 & 0 & 5 & 213 & 2 & 1 & 121 & 8 & 0 & 0 & 0 \\
\hline Hortobágy III. & 0 & 2 & 0 & 123 & 70 & 9 & 7 & 8 & 0 & 0 & 0 \\
\hline $\begin{array}{l}\text { Kardoskúti Fehér-tó } \\
\text { Lake Fehér at Kardoskút }\end{array}$ & 0 & 37 & 14 & 5 & 0 & 6 & 0 & 0 & 0 & 0 & 0 \\
\hline $\begin{array}{l}\text { Biharugrai és Begécsi halastavak } \\
\text { Fishponds at Biharugra and Begécs }\end{array}$ & 0 & 16 & 1 & 56 & 190 & 11 & 0 & 3 & 0 & 0 & 0 \\
\hline $\begin{array}{l}\text { Tömörkényi Csaj-tó } \\
\text { Lake Csaj at Tömörkény }\end{array}$ & 0 & 16 & 0 & 25 & 1 & 6 & 0 & 1 & 0 & 0 & 0 \\
\hline $\begin{array}{l}\text { Szegedi Fehér-tó és Fertő } \\
\text { Lake Fehér and Fertő at Szeged }\end{array}$ & 0 & 7 & 2 & 16 & 6 & 24 & 7 & 1 & 0 & 0 & 0 \\
\hline $\begin{array}{l}\text { Tiszántúl } \\
\text { Transtisza }\end{array}$ & 0 & 124 & 108 & 504 & 270 & 86 & 151 & 71 & 0 & 50 & 8 \\
\hline $\begin{array}{l}\text { Magyarország összesen } \\
\text { Hungary total }\end{array}$ & 0 & 216 & 779 & 784 & 439 & 361 & 229 & 134 & 2 & 51 & 30 \\
\hline
\end{tabular}




\section{0. melléklet: A barátréce becsült átlagos állománynagysága a vadászati idényben Magyarországon, 1996-2008}

Appendix 20: Average population size of Common Pochard in the hunting seasons in Hungary, 1996-2008

\begin{tabular}{|c|c|c|c|c|c|c|c|c|c|c|c|c|}
\hline $\begin{array}{l}\text { Terület, régió } \\
\text { Site, region }\end{array}$ & 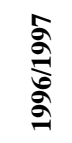 & $\stackrel{\infty}{\stackrel{\circ}{\sigma}}$ & $\frac{\stackrel{\circ}{\sigma}}{\stackrel{\circ}{\sigma}}$ & 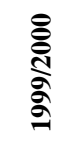 & 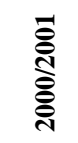 & 令 & 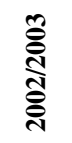 & 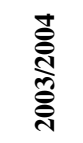 & 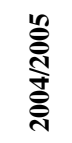 & 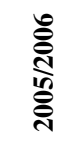 & 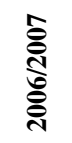 & 产 \\
\hline $\begin{array}{l}\text { Fertő-tó } \\
\text { Lake Fertő }\end{array}$ & 36 & 10 & 6 & 8 & 23 & 13 & 6 & 4 & 1 & 5 & 2 & 3 \\
\hline $\begin{array}{l}\text { Duna Gönyü-Szob } \\
\text { River Danube, Gönyü-Szob }\end{array}$ & 80 & 4 & 38 & 0 & 7 & 0 & 18 & 8 & 46 & 99 & 14 & 3 \\
\hline $\begin{array}{l}\text { Tatai Öreg-tó } \\
\text { Old Lake at Tata }\end{array}$ & 6 & 18 & 108 & 5 & 9 & 9 & 0 & 2 & 4 & 1 & 36 & 3 \\
\hline Dinnyési Fertő & 4 & 3 & 44 & 9 & 0 & 2 & 1 & 1 & 0 & 22 & 2 & 0 \\
\hline $\begin{array}{l}\text { Velencei-tó } \\
\text { Lake Velence }\end{array}$ & 0 & 27 & 60 & 10 & 18 & 14 & 3 & 3 & 5 & 16 & 0 & 5 \\
\hline $\begin{array}{l}\text { Soponyai-halastavak } \\
\text { Fishponds at Soponya }\end{array}$ & 0 & 1 & 63 & 8 & 38 & 32 & 24 & 11 & 31 & 83 & 87 & 30 \\
\hline $\begin{array}{l}\text { Rétszilasi-halastavak } \\
\text { Fishponds at Rétszilas }\end{array}$ & 27 & 71 & 90 & 59 & 78 & 116 & 84 & 108 & 30 & 27 & 59 & 25 \\
\hline $\begin{array}{l}\text { Dunakanyar } \\
\text { Danube bend }\end{array}$ & 70 & 83 & 153 & 69 & 112 & 146 & 146 & 76 & 112 & 140 & 131 & 135 \\
\hline $\begin{array}{l}\text { Észak-Dunántúl } \\
\text { Northern Transdanubia }\end{array}$ & 223 & 217 & 562 & 168 & 285 & 332 & 282 & 213 & 228 & 391 & 331 & 203 \\
\hline $\begin{array}{l}\text { Balaton, Keszthelyi-öböl } \\
\text { Lake Balaton, Keszthelyi bay }\end{array}$ & 525 & 95 & 125 & 443 & 788 & 309 & 200 & 48 & 283 & 85 & 46 & 263 \\
\hline Kis-Balaton & 171 & 492 & 234 & 524 & 423 & 128 & 105 & 28 & 134 & 383 & 322 & 293 \\
\hline $\begin{array}{l}\text { Dráva Barcs-Szentborbás } \\
\text { River Dráva, Barcs-Szentborbás }\end{array}$ & 4 & 0 & 1 & 0 & 0 & 0 & 2 & 0 & 3 & 5 & 2 & 25 \\
\hline $\begin{array}{l}\text { Gyékényesi-kavicsbányató } \\
\text { Gravel pit at Gyékényes }\end{array}$ & 0 & 1 & 51 & 76 & 0 & 3 & 1 & 6 & 1 & 6 & 1 & 3 \\
\hline $\begin{array}{l}\text { Sumonyi-halastavak } \\
\text { Fishponds at Sumony }\end{array}$ & 313 & 144 & 25 & 29 & 36 & 262 & 209 & 213 & 90 & 28 & 53 & 127 \\
\hline $\begin{array}{l}\text { Pellérdi-halastavak } \\
\text { Fishponds at Pellérd }\end{array}$ & 75 & 33 & 0 & 10 & 1 & 22 & 1 & 8 & 8 & 0 & 10 & 0 \\
\hline $\begin{array}{l}\text { Dél-Dunántúl } \\
\text { Southern Transdanubia }\end{array}$ & 1088 & 765 & 436 & 1082 & 1248 & 724 & 518 & 303 & 517 & 506 & 434 & 710 \\
\hline $\begin{array}{l}\text { Duna Baja-országhatár } \\
\text { River Danube, Baja-state border }\end{array}$ & 416 & 65 & 628 & 1 & 168 & 253 & 114 & 148 & 31 & 287 & 111 & 228 \\
\hline $\begin{array}{l}\text { Kiskunsági szikes tavak } \\
\text { Natron lakes in Kiskunság }\end{array}$ & 33 & 3 & 0 & 2 & 1 & 1 & 0 & 0 & 0 & 7 & 2 & 50 \\
\hline $\begin{array}{l}\text { Duna-Tisza köze } \\
\text { Danube-Tisza Interfluve }\end{array}$ & 449 & 68 & 628 & 3 & 169 & 254 & 114 & 148 & 31 & 294 & 113 & 278 \\
\hline Hortobágy I. & 102 & 57 & 41 & 18 & 4 & 115 & 79 & 324 & 273 & 293 & 421 & 209 \\
\hline Hortobágy II. & 70 & 24 & 97 & 23 & 16 & 45 & 86 & 94 & 90 & 107 & 99 & 47 \\
\hline Hortobágy III. & 52 & 4 & 36 & 171 & 32 & 89 & 16 & 139 & 48 & 254 & 86 & 59 \\
\hline $\begin{array}{l}\text { Kardoskúti Fehér-tó } \\
\text { Lake Fehér at Kardoskút }\end{array}$ & 0 & 0 & 0 & 3 & 0 & 0 & 0 & 0 & 0 & 0 & 0 & 0 \\
\hline $\begin{array}{l}\text { Biharugrai és Begécsi halastavak } \\
\text { Fishponds at Biharugra and Begécs }\end{array}$ & 380 & 188 & 376 & 64 & 28 & 328 & 30 & 162 & 694 & 377 & 187 & 132 \\
\hline $\begin{array}{l}\text { Tömörkényi Csaj-tó } \\
\text { Lake Csaj at Tömörkény }\end{array}$ & 408 & 673 & 391 & 66 & 6 & 114 & 78 & 126 & 101 & 110 & 225 & 195 \\
\hline $\begin{array}{l}\text { Szegedi Fehér-tó és Fertő } \\
\text { Lake Fehér and Fertö at Szeged }\end{array}$ & 62 & 91 & 15 & 103 & 219 & 288 & 259 & 189 & 145 & 253 & 147 & 240 \\
\hline $\begin{array}{l}\text { Tiszántúl } \\
\text { Transtisza }\end{array}$ & 1074 & 1037 & 956 & 448 & 305 & 979 & 548 & 1034 & 1350 & 1393 & 1164 & 882 \\
\hline $\begin{array}{l}\text { Magyarország összesen } \\
\text { Hungary total }\end{array}$ & 2834 & 2087 & 2582 & 1701 & 2007 & 2289 & 1462 & 1698 & 2126 & 2584 & 2042 & 2072 \\
\hline
\end{tabular}




\section{1. melléklet: A kerceréce becsült átlagos állománynagysága a vadászati idényben Magyarországon, 1996-2012}

Appendix 21: Average population size of Common Goldeneye in hunting seasons in Hungary, 19962012

\begin{tabular}{|c|c|c|c|c|c|c|c|c|c|c|c|c|c|c|c|c|}
\hline $\begin{array}{l}\text { Terület, régió } \\
\text { Site, region }\end{array}$ & $\begin{array}{l}\hat{\alpha} \\
\stackrel{\hat{\sigma}}{\circ} \\
\stackrel{2}{2}\end{array}$ & $\underset{\hat{\sigma}}{\stackrel{\infty}{\hat{~}}}$ & $\begin{array}{l}\stackrel{\partial}{\circ} \\
\stackrel{2}{\circ} \\
\stackrel{\sigma}{\sigma}\end{array}$ & 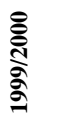 & 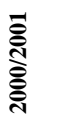 & 芯 & 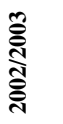 & 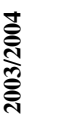 & 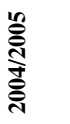 & 䒽 & 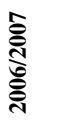 & 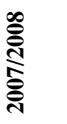 & 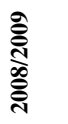 & 옳 & 홏 & 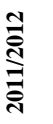 \\
\hline $\begin{array}{l}\text { Fertö-tó } \\
\text { Lake Fertő }\end{array}$ & 0 & 0 & 0 & 2 & 1 & 1 & 2 & 0 & 0 & 0 & 1 & 1 & 0 & 4 & 1 & 0 \\
\hline $\begin{array}{l}\text { Duna Gönyü-Szob } \\
\text { River Danube, Gönyü-Szob }\end{array}$ & 584 & 293 & 297 & 803 & 198 & 392 & 131 & 207 & 374 & 532 & 174 & 768 & 1028 & 550 & 642 & 261 \\
\hline $\begin{array}{l}\text { Tatai Öreg-tó } \\
\text { Old Lake at Tata }\end{array}$ & 1 & 0 & 1 & 1 & 0 & 0 & 0 & 1 & 0 & 1 & 6 & 0 & 2 & 8 & 39 & 0 \\
\hline Dinnyési Fertő & 0 & 0 & 12 & 2 & 2 & 1 & 0 & 0 & 0 & 0 & 1 & 0 & 1 & 0 & 6 & 7 \\
\hline $\begin{array}{l}\text { Velencei-tó } \\
\text { Lake Velence }\end{array}$ & 0 & 5 & 36 & 0 & 0 & 1 & 0 & 2 & 0 & 0 & 4 & 0 & 8 & 3 & 8 & 21 \\
\hline $\begin{array}{l}\text { Soponyai-halastavak } \\
\text { Fishponds at Soponya }\end{array}$ & 0 & 0 & 0 & 0 & 0 & 0 & 1 & 2 & 1 & 0 & 0 & 4 & 1 & 3 & 0 & 0 \\
\hline $\begin{array}{l}\text { Rétszilasi-halastavak } \\
\text { Fishponds at Rétszilas }\end{array}$ & 0 & 0 & 2 & 2 & 1 & 0 & 0 & 1 & 1 & 1 & 0 & 1 & 2 & 1 & 2 & 0 \\
\hline $\begin{array}{l}\text { Dunakanyar } \\
\text { Danube bend }\end{array}$ & 462 & 300 & 687 & 499 & 335 & 465 & 532 & 481 & 321 & 653 & 369 & 594 & 473 & 356 & 263 & 304 \\
\hline $\begin{array}{l}\text { Észak-Dunántúl } \\
\text { Northern Transdanubia }\end{array}$ & 1047 & 598 & 1035 & 1309 & 537 & 860 & 666 & 694 & 697 & 1186 & 555 & 1367 & 1514 & 924 & 959 & 593 \\
\hline $\begin{array}{l}\text { Balaton, Keszthelyi-öböl } \\
\text { Lake Balaton, Keszthelyi bay }\end{array}$ & 175 & 88 & 41 & 942 & 1250 & 117 & 34 & 137 & 552 & 162 & 206 & 12 & 319 & 801 & 37 & 285 \\
\hline Kis-Balaton & 62 & 52 & 109 & 50 & 76 & 11 & 5 & 2 & 9 & 10 & 18 & 69 & 1 & 4 & 32 & 0 \\
\hline $\begin{array}{l}\text { Dráva Barcs-Szentborbás } \\
\text { River Dráva, Barcs-Szentborbás }\end{array}$ & 75 & 3 & 16 & 50 & 0 & 0 & 41 & 20 & 1 & 2 & 1 & 4 & 0 & 0 & 3 & 1 \\
\hline $\begin{array}{l}\text { Gyékényesi-kavicsbányató } \\
\text { Gravel pit at Gyékényes }\end{array}$ & 1 & 0 & 1 & 6 & 0 & 6 & 0 & 0 & 4 & 8 & 0 & 47 & 27 & 1 & 6 & 0 \\
\hline $\begin{array}{l}\text { Sumonyi-halastavak } \\
\text { Fishponds at Sumony }\end{array}$ & 13 & 8 & 10 & 15 & 4 & 3 & 2 & 1 & 12 & 18 & 20 & 8 & 0 & 10 & 0 & 0 \\
\hline $\begin{array}{l}\text { Pellérdi-halastavak } \\
\text { Fishponds at Pellérd }\end{array}$ & 1 & 0 & 0 & 3 & 0 & 0 & 0 & 0 & 0 & 0 & 0 & 0 & 0 & 0 & 1 & 0 \\
\hline $\begin{array}{l}\text { Dél-Dunántúl } \\
\text { Southern Transdanubia }\end{array}$ & 327 & 151 & 177 & 1066 & 1330 & 137 & 82 & 160 & 577 & 199 & 245 & 140 & 347 & 815 & 79 & 287 \\
\hline $\begin{array}{l}\text { Duna Baja-országhatár } \\
\text { River Danube, Baja-state border }\end{array}$ & 363 & 48 & 190 & 310 & 17 & 214 & 116 & 106 & 34 & 115 & 27 & 278 & 71 & 33 & 221 & 8 \\
\hline $\begin{array}{l}\text { Kiskunsági szikes tavak } \\
\text { Natron lakes in Kiskunság }\end{array}$ & 0 & 0 & 0 & 0 & 0 & 0 & 0 & 0 & 0 & 0 & 2 & 0 & 0 & 0 & 0 & 0 \\
\hline $\begin{array}{l}\text { Duna-Tisza köze } \\
\text { Danube-Tisza Interfluve }\end{array}$ & 363 & 48 & 190 & 310 & 17 & 214 & 116 & 106 & 34 & 115 & 29 & 278 & 71 & 33 & 221 & 8 \\
\hline Hortobágy I. & 9 & 41 & 1 & 15 & 11 & 1 & 2 & 2 & 12 & 3 & 1 & 0 & 6 & 5 & 3 & 4 \\
\hline Hortobágy II. & 0 & 9 & 3 & 4 & 2 & 1 & 0 & 1 & 14 & 0 & 0 & 0 & 0 & 9 & 1 & 0 \\
\hline Hortobágy III. & 4 & 3 & 2 & 6 & 4 & 0 & 5 & 8 & 3 & 0 & 4 & 1 & 0 & 0 & 2 & 6 \\
\hline $\begin{array}{l}\text { Kardoskúti Fehér-tó } \\
\text { Lake Fehér at Kardoskút }\end{array}$ & 0 & 0 & 0 & 0 & 0 & 0 & 0 & 0 & 0 & 0 & 0 & 0 & 0 & 0 & 0 & 0 \\
\hline $\begin{array}{l}\text { Biharugrai és Begécsi halastavak } \\
\text { Fishponds at Biharugra and Begécs }\end{array}$ & 0 & 40 & 21 & 23 & 2 & 5 & 5 & 12 & 45 & 10 & 15 & 16 & 12 & 20 & 15 & 12 \\
\hline $\begin{array}{l}\text { Tömörkényi Csaj-tó } \\
\text { Lake Csaj at Tömörkény }\end{array}$ & 2 & 27 & 9 & 0 & 8 & 4 & 10 & 1 & 9 & 6 & 3 & 8 & 6 & 7 & 3 & 5 \\
\hline $\begin{array}{l}\text { Szegedi Fehér-tó és Fertő } \\
\text { Lake Fehér and Fertő at Szeged }\end{array}$ & 7 & 13 & 6 & 8 & 14 & 5 & 1 & 1 & 13 & 10 & 13 & 2 & 5 & 1 & 11 & 2 \\
\hline $\begin{array}{l}\text { Tiszántúl } \\
\text { Transtisza }\end{array}$ & 22 & 133 & 42 & 56 & 41 & 16 & 23 & 25 & 96 & 30 & 35 & 28 & 29 & 42 & 34 & 28 \\
\hline $\begin{array}{l}\text { Magyarország összesen } \\
\text { Hungary total }\end{array}$ & 1759 & 930 & 1444 & 2741 & 1925 & 1227 & 887 & 985 & 1404 & 1530 & 863 & 1812 & 1960 & 1813 & 1293 & 915 \\
\hline
\end{tabular}




\section{2. melléklet: A szárcsa becsült átlagos állománynagysága a vadászati idényben Magyarországon, 1996-2016}

Appendix 22: Average population size of Eurasian Coot in the hunting seasons in Hungary, 1996-2016

\begin{tabular}{|c|c|c|c|c|c|c|c|c|c|c|c|c|c|c|c|c|c|c|c|c|}
\hline $\begin{array}{l}\text { Terület, régió } \\
\text { Site, region }\end{array}$ & ڤે̀े & $\stackrel{\infty}{\hat{\sigma}}$ & $\begin{array}{l}\stackrel{\partial}{\circ} \\
\stackrel{\sigma}{\sigma}\end{array}$ & 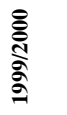 & 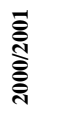 & 蒿 & 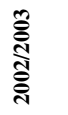 & 突 & 苍 & 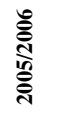 & 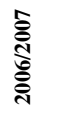 & 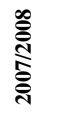 & 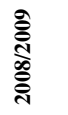 & 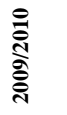 & $\overline{\bar{\Xi}}$ & $\underset{\bar{I}}{\stackrel{\bar{I}}{3}}$ & & 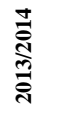 & & 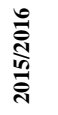 \\
\hline $\begin{array}{l}\text { Fertö-tó } \\
\text { Lake Fertö }\end{array}$ & 97 & 76 & 0 & 90 & 118 & 10 & 36 & 134 & 31 & 24 & 24 & 23 & 16 & 107 & 42 & 68 & 41 & 106 & 16 & 110 \\
\hline $\begin{array}{l}\text { Duna Gönyü-Szob } \\
\text { River Danube, Gönyü-Szob }\end{array}$ & 17 & 0 & 297 & 48 & 3 & 34 & 18 & 3 & 0 & 15 & 0 & 0 & 0 & 21 & 21 & 0 & 0 & 0 & 0 & 1 \\
\hline $\begin{array}{l}\text { Tatai Öreg-tó } \\
\text { Old Lake at Tata }\end{array}$ & 10 & 62 & 1 & 11 & 45 & 6 & 0 & 0 & 0 & 1 & 5 & 0 & 3 & 0 & 16 & 0 & 0 & 6 & 1 & 17 \\
\hline Dinnyési Fertő & 26 & 3 & 12 & 2 & 0 & 250 & 21 & 59 & 244 & 147 & 47 & 12 & 3 & 0 & 322 & 1 & 0 & 18 & 5 & 0 \\
\hline $\begin{array}{l}\text { Velencei-tó } \\
\text { Lake Velence }\end{array}$ & 63 & 43 & 36 & 58 & 84 & 185 & 17 & 111 & 128 & 130 & 3 & 79 & 122 & 60 & 92 & 64 & 94 & 48 & 1 & 4 \\
\hline $\begin{array}{l}\text { Soponyai-halastavak } \\
\text { Fishponds at Soponya }\end{array}$ & 13 & 58 & 0 & 314 & 35 & 153 & 343 & 223 & 521 & 1039 & 836 & 617 & 362 & 171 & 287 & 293 & 91 & 337 & 362 & 396 \\
\hline $\begin{array}{l}\text { Rétszilasi-halastavak } \\
\text { Fishponds at Rétszilas }\end{array}$ & 69 & 45 & 2 & 461 & 144 & 508 & 934 & 429 & 176 & 1380 & 494 & 404 & 609 & 957 & 346 & 313 & 202 & 514 & 551 & 218 \\
\hline $\begin{array}{l}\text { Dunakanyar } \\
\text { Danube bend }\end{array}$ & 16 & 9 & 687 & 12 & 23 & 121 & 105 & 144 & 81 & 135 & 2 & 72 & 318 & 82 & 55 & 32 & 171 & 228 & 131 & 206 \\
\hline $\begin{array}{l}\text { Észak-Dunántúl } \\
\text { Northern Transdanubia }\end{array}$ & 311 & 296 & 1035 & 996 & 452 & 1267 & 1474 & 1103 & 1181 & 2872 & 1412 & 1208 & 1432 & 1399 & 1181 & 771 & 599 & 1258 & 1067 & 954 \\
\hline $\begin{array}{l}\text { Balaton, Keszthelyi-öböl } \\
\text { Lake Balaton, Keszthelyi bay }\end{array}$ & 500 & 975 & 41 & 568 & 41 & 75 & 388 & 30 & 120 & 290 & 391 & 312 & 458 & 794 & 548 & 623 & 196 & 222 & 235 & 657 \\
\hline Kis-Balaton & 1293 & 1243 & 109 & 2158 & 663 & 2140 & 1291 & 442 & 821 & 943 & 1296 & 331 & 744 & 342 & 471 & 1171 & 498 & 609 & 768 & 737 \\
\hline $\begin{array}{l}\text { Dráva Barcs-Szentborbás } \\
\text { River Dráva, Barcs- } \\
\text { Szentborbás }\end{array}$ & 14 & 0 & 16 & 0 & 2035 & 0 & 1 & 1 & 40 & 104 & 6 & 22 & 10 & 46 & 5 & 15 & 42 & 18 & 50 & 119 \\
\hline $\begin{array}{l}\text { Gyékényesi-kavicsbányató } \\
\text { Gravel pit at Gyékényes }\end{array}$ & 22 & 230 & 1 & 90 & 233 & 73 & 77 & 91 & 0 & 0 & 0 & 7 & 0 & 0 & 16 & 0 & 0 & 0 & 0 & 0 \\
\hline $\begin{array}{l}\text { Sumonyi-halastavak } \\
\text { Fishponds at Sumony }\end{array}$ & 275 & 108 & 10 & 105 & 11 & 440 & 381 & 224 & 122 & 166 & 353 & 272 & 327 & 260 & 241 & 176 & 62 & 208 & 102 & 200 \\
\hline $\begin{array}{l}\text { Pellérdi-halastavak } \\
\text { Fishponds at Pellérd }\end{array}$ & 2 & 77 & 0 & 11 & 14 & 235 & 280 & 5 & 136 & 39 & 90 & 2 & 19 & 0 & 205 & 201 & 0 & 73 & 98 & 40 \\
\hline $\begin{array}{l}\text { Dél-Dunántúl } \\
\text { Southern Transdanubia }\end{array}$ & 2106 & 2633 & 177 & 2932 & 2997 & 2963 & 2418 & 793 & 1240 & 1542 & 2137 & 946 & 1557 & 1442 & 1486 & 2185 & 797 & 1129 & 1255 & 1753 \\
\hline $\begin{array}{l}\text { Duna Baja-országhatár } \\
\text { River Danube, Baja-state } \\
\text { border }\end{array}$ & 53 & 11 & 190 & 58 & 3 & 40 & 19 & 20 & 16 & 44 & 10 & 131 & 83 & 163 & 170 & 13 & 12 & 4 & 19 & 40 \\
\hline $\begin{array}{l}\text { Kiskunsági szikes tavak } \\
\text { Natron lakes in Kiskunság }\end{array}$ & 26 & 8 & 0 & 10 & 0 & 0 & 0 & 0 & 0 & 0 & 0 & 0 & 0 & 0 & 32 & 3 & 0 & 0 & 2 & 1 \\
\hline $\begin{array}{l}\text { Duna-Tisza köze } \\
\text { Danube-Tisza Interfluve }\end{array}$ & 79 & 19 & 190 & 68 & 3 & 40 & 19 & 20 & 16 & 44 & 10 & 131 & 83 & 163 & 202 & 15 & 12 & 4 & 21 & 41 \\
\hline Hortobágy I. & 219 & 103 & 1 & 666 & 244 & 278 & 279 & 740 & 1226 & 476 & 702 & 671 & 822 & 765 & 841 & 961 & 455 & 993 & 1452 & 1536 \\
\hline Hortobágy II. & 2738 & 79 & 3 & 737 & 325 & 465 & 1191 & 970 & 924 & 441 & 790 & 210 & 1384 & 250 & 312 & 461 & 193 & 462 & 696 & 579 \\
\hline Hortobágy III. & 168 & 336 & 2 & 113 & 453 & 249 & 181 & 93 & 133 & 195 & 506 & 265 & 320 & 420 & 110 & 354 & 116 & 128 & 82 & 65 \\
\hline $\begin{array}{l}\text { Kardoskúti Fehér-tó } \\
\text { Lake Fehér at Kardoskút }\end{array}$ & 0 & 25 & 0 & 1 & 0 & 0 & 0 & 0 & 0 & 6 & 0 & 0 & 0 & 0 & 0 & 0 & 0 & 0 & 0 & 0 \\
\hline $\begin{array}{l}\text { Biharugrai és Begécsi } \\
\text { halastavak } \\
\text { Fishponds at Biharugra and } \\
\text { Begécs }\end{array}$ & 1630 & 536 & 21 & 395 & 814 & 4572 & 1252 & 1376 & 1998 & 1297 & 687 & 373 & 846 & 198 & 526 & 105 & 88 & 480 & 271 & 260 \\
\hline $\begin{array}{l}\text { Tömörkényi Csaj-tó } \\
\text { Lake Csaj at Tömörkény }\end{array}$ & 28 & 215 & 9 & 6 & 6 & 75 & 107 & 135 & 175 & 54 & 138 & 22 & 50 & 34 & 31 & 19 & 11 & 19 & 107 & 181 \\
\hline $\begin{array}{l}\text { Szegedi Fehér-tó és Fertö } \\
\text { Lake Fehér and Fertö at Szeged }\end{array}$ & 56 & 13 & 6 & 71 & 187 & 308 & 270 & 479 & 1043 & 341 & 1007 & 1752 & 446 & 2573 & 522 & 1514 & 415 & 136 & 160 & 40 \\
\hline $\begin{array}{l}\text { Tiszántúl } \\
\text { Transtisza }\end{array}$ & 4839 & 1307 & 42 & 1989 & 2029 & 5947 & 3280 & 3793 & 5499 & 2811 & 3830 & 3293 & 3869 & 4239 & 2342 & 3415 & 1277 & 2218 & 2767 & 2660 \\
\hline $\begin{array}{l}\text { Magyarország összesen } \\
\text { Hungary total }\end{array}$ & 7335 & 4255 & 1444 & 5985 & 5481 & 10217 & 7191 & 5709 & 7935 & 7268 & 7388 & 5578 & 6942 & 7244 & 5210 & 6386 & 2686 & 4609 & 5110 & 5408 \\
\hline
\end{tabular}




\section{3.a. melléklet: A becsült és terítékre hozott vetési lúd és nagy lilik átlagos mennyisége a vadászidényben ökorégiónként}

Appendix 23.a.: Average number and bag size of Bean Goose and Greater White-fronted Goose in hunting seasons in each eco-regions

\begin{tabular}{|c|c|c|c|c|c|c|c|c|c|c|c|c|c|}
\hline Vetési lúd & & $\underset{\hat{\sigma}}{\sigma}$ & 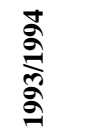 & 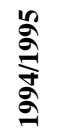 & $\underset{\sigma}{\stackrel{\partial}{\sigma}}$ & 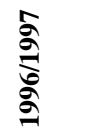 & $\underset{\sigma}{\stackrel{2}{\sigma}}$ & $\underset{\stackrel{\partial}{\sigma}}{\stackrel{\alpha}{\sigma}}$ & 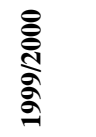 & 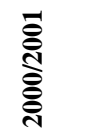 & 옹 & 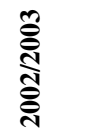 & 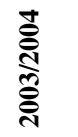 \\
\hline Észak-Dunántúl & becsl./est. & 33296 & 22030 & 44456 & 25414 & 29136 & 28094 & 31338 & 17704 & 15627 & 12495 & 10317 & 17386 \\
\hline N. Transdanubia & ter./bag & 1462 & 2034 & 2347 & 2484 & 2042 & 2105 & 2017 & 2446 & 2204 & 1587 & 1577 & 1669 \\
\hline Dél-Dunántúl & becsl./est. & 12353 & 25896 & 28899 & 15737 & 20950 & 13302 & 29095 & 19516 & 11632 & 12981 & 14094 & 12075 \\
\hline S. Transdanubia & ter./bag & 1221 & 1306 & 1571 & 1198 & 1675 & 788 & 1523 & 1317 & 652 & 771 & 658 & 750 \\
\hline Észak-Magyarország & becsl./est. & 3 & 128 & 1 & 0 & 0 & 150 & 40 & 425 & 482 & 40 & 0 & 205 \\
\hline N. Hungary & ter./bag & 53 & 159 & 218 & 209 & 118 & 95 & 25 & 73 & 198 & 65 & 73 & 112 \\
\hline Duna-Tisza köze & becsl./est. & 5499 & 9375 & 9132 & 6467 & 6070 & 5779 & 2900 & 1335 & 892 & 2681 & 244 & 1336 \\
\hline Danube-Tisza Interfluve & ter./bag & 758 & 485 & 1422 & 1142 & 1302 & 980 & 1048 & 1562 & 740 & 288 & 182 & 348 \\
\hline Tiszántúl & becsl./est. & 2522 & 2699 & 919 & 222 & 308 & 469 & 122 & 403 & 290 & 135 & 96 & 87 \\
\hline Transtisza & ter./bag & 360 & 530 & 513 & 401 & 440 & 631 & 538 & 594 & 595 & 441 & 249 & 365 \\
\hline Magyaro. össz. & becsl./est. & 53673 & 60128 & 83407 & 47840 & 56464 & 47794 & 63495 & 39383 & 28923 & 28332 & 24751 & 31089 \\
\hline Hungary total & ter./bag & 3854 & 4514 & 6071 & 5434 & 5577 & 4599 & 5151 & 5992 & 4389 & 3152 & 2739 & 3244 \\
\hline Vetési lúd & & 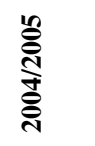 & 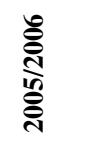 & 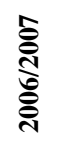 & 㝕 & 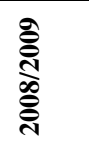 & 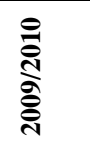 & $\begin{array}{l}\overline{\bar{\Xi}} \\
\bar{\Xi} \\
\bar{\Xi}\end{array}$ & 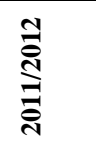 & 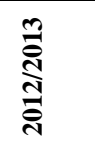 & 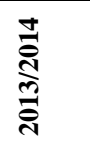 & 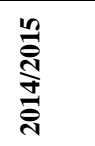 & 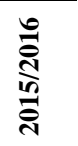 \\
\hline Észak-Dunántúl & becsl./est. & 1574 & 1710 & 3099 & 1424 & 1068 & 793 & 815 & 862 & 382 & 462 & 89 & 63 \\
\hline N. Transdanubia & ter./bag & 1528 & 1793 & 1690 & 2373 & 2622 & 2271 & 1775 & 2515 & 1426 & 1201 & 593 & 683 \\
\hline Dél-Dunántúl & becsl./est. & 1867 & 1645 & 697 & 403 & 493 & 340 & 309 & 350 & 212 & 47 & 28 & 110 \\
\hline S. Transdanubia & ter./bag & 538 & 322 & 198 & 515 & 318 & 303 & 293 & 266 & 191 & 81 & 87 & 79 \\
\hline Észak-Magyarország & becsl./est. & 275 & 275 & 325 & 287,5 & 128 & 150 & 20 & 22,5 & 5 & 0 & 0 & 0 \\
\hline N. Hungary & ter./bag & 39 & 49 & 52 & 13 & 23 & 10 & 72 & 106 & 50 & 29 & 4 & 39 \\
\hline Duna-Tisza köze & becsl./est. & 313 & 609 & 435 & 201 & 170 & 775 & 113 & 48 & 76 & 110 & 99 & 75 \\
\hline Danube-Tisza Interfluve & ter./bag & 376 & 327 & 224 & 225 & 186 & 310 & 461 & 219 & 236 & 205 & 227 & 134 \\
\hline Tiszántúl & becsl./est. & 27 & 7 & 24 & 25 & 16 & 38 & 6 & 2 & 0 & 0 & 7 & 0 \\
\hline Transtisza & ter./bag & 275 & 190 & 228 & 307 & 185 & 243 & 462 & 324 & 197 & 208 & 269 & 217 \\
\hline Magyaro. össz. & becsl./est. & 21678 & 21664 & 24089 & 11779 & 9912 & 8687 & 7022 & 7396 & 3615 & 3271 & 933 & $\overline{1190}$ \\
\hline Hungary total & ter./bag & 2756 & 2681 & 2392 & 3433 & 3334 & 3137 & 3063 & 3430 & 2100 & 1724 & 1180 & 1152 \\
\hline
\end{tabular}




\section{3.a. melléklet: A becsült és terítékre hozott vetési lúd és nagy lilik átlagos mennyisége a vadászidényben ökorégiónként}

Appendix 23.a.: Average number and bag size of Bean Goose and Greater White-fronted Goose in hunting seasons in each eco-regions

\begin{tabular}{|c|c|c|c|c|c|c|c|c|c|c|c|c|c|}
\hline Nagy lilik & & $\underset{\hat{\sigma}}{\widehat{\sigma}}$ & $\underset{\sigma}{\stackrel{\Xi}{\sigma}}$ & $\begin{array}{l}\stackrel{2}{\partial} \\
\text { જે }\end{array}$ & $\underset{\sigma}{\stackrel{2}{2}}$ & $\frac{\hat{\sigma}}{\hat{\sigma}}$ & $\underset{\sigma}{\stackrel{\circ}{\sigma}}$ & $\begin{array}{l}\stackrel{\circ}{\circ} \\
\stackrel{\circ}{\sigma}\end{array}$ & 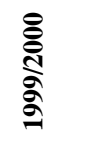 & 离 & 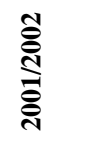 & 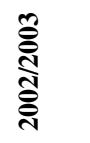 & 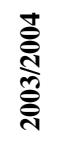 \\
\hline Észak-Dunántúl & csl./est. & 3631 & 3010 & 8887 & 2721 & 4604 & 5873 & 8750 & 5370 & 25524 & 6143 & 4695 & 6735 \\
\hline N. Transdanubia & Ibag & 299 & 26 & 25 & 16 & 55 & 76 & 116 & 177 & 179 & 202 & 322 & 283 \\
\hline Dél-Dunántúl & csl./est. & 2015 & 3750 & 5776 & 7557 & 6828 & 3250 & 0250 & 7162 & 4716 & 4744 & 8130 & 6013 \\
\hline Transda &.$/ b a g$ & 450 & 0 & 72 & 55 & 8 & 27 & 69 & 188 & 48 & 59 & 30 & 238 \\
\hline Észak-Magya & csl./est. & 267 & 800 & 357 & 34 & 694 & 82 & 145 & 450 & 187 & 145 & 1350 & 2950 \\
\hline N. Hungary & ter./bag & 40 & 7 & 22 & 5 & 48 & 1 & 5 & 28 & 30 & 57 & 60 & 285 \\
\hline Duna-Tisza köze & csl./est. & 4037 & 8600 & 15203 & 3700 & 1735 & 1915 & 1772 & 1022 & 4111 & 3800 & 1604 & 1456 \\
\hline Danube-Tisza Inter & ter./bag & 365 & 65 & 111 & 45 & 29 & 188 & 259 & 360 & 633 & 292 & 275 & 360 \\
\hline Tiszántúl & becsl./est. & 16982 & 20981 & 9218 & 6140 & 15349 & 9845 & 9806 & 13500 & 17242 & 12132 & 10291 & 18460 \\
\hline Transtisza & ter./bag & 330 & 80 & 106 & 67 & 176 & 147 & 309 & 490 & 1156 & 540 & 383 & 583 \\
\hline Magyaro. össz. & & 26932 & 37141 & 9441 & 0152 & & 965 & 0723 & 30504 & 51780 & 26964 & 26070 & 45614 \\
\hline Hungary total & that & 1484 & 178 & 336 & 188 & 316 & 439 & 758 & 1243 & 2046 & 1150 & 1070 & 174 \\
\hline Nagy & & 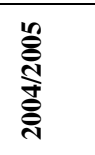 & 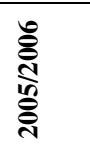 & 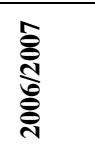 & 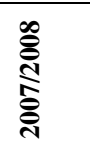 & 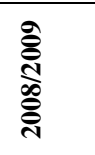 & 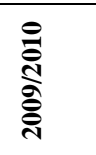 & 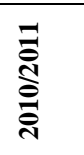 & 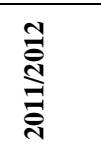 & 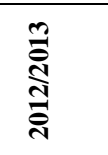 & 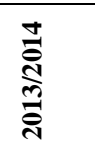 & 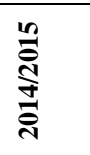 & 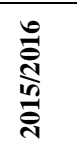 \\
\hline zak & & 2376 & 3733 & 5508 & 4373 & 7554 & 51 & 58 & & 9374 & 9239 & 3733 & 4169 \\
\hline N. Transdanubia & ter./bag & 542 & 648 & 621 & 938 & 949 & 1185 & 1202 & 1950 & 2500 & 2672 & 2254 & 2395 \\
\hline Dél-Dunántúl & becsl./est. & 855 & 742 & 942 & 259 & 546 & 265 & 395 & 375 & 879 & 702 & 517 & 42 \\
\hline nubia & ter./bag & 114 & 67 & 26 & & & 109 & 125 & 0 & 197 & 134 & 107 & 13 \\
\hline Észak-Magyarország & becsl./est. & 3500 & 7000 & 1800 & 1750 & 1125 & 1055 & 363 & 500 & 300 & 425 & 2300 & 1225 \\
\hline N. Hungary & ter./bag & 188 & 179 & 238 & 207 & 423 & 147 & 295 & 790 & 878 & 1245 & 601 & 1415 \\
\hline Duna-Tisza köze & becsl./est. & 1104 & 4216 & 1013 & 89 & 1912 & 2537 & 2645 & 3513 & 2854 & 3026 & 1448 & 2754 \\
\hline Danube-Tisza Inter & ter./bag & 528 & 675 & 877 & 814 & 1181 & 1009 & 2410 & 2044 & 2235 & 2202 & 4287 & 305 \\
\hline Tiszántúl & becsl./est. & 4686 & 3541 & 2419 & 5080 & 3233 & 12124 & 9326 & 7936 & 6803 & 6374 & 7723 & 7130 \\
\hline Transtisza & ter./bag & 745 & 339 & 1173 & 1400 & 1114 & 2468 & 2743 & 3552 & 2511 & 4186 & 3191 & 3483 \\
\hline Magyaro. össz. & becsl./est. & 48520 & 59990 & 54626 & 55117 & 69712 & 99060 & 89814 & 106163 & 101098 & 97994 & 69303 & 69963 \\
\hline Hungary total & ter./bag & 2117 & 1908 & 2935 & 3478 & 3815 & 4918 & 6775 & 8456 & 8321 & 10439 & 10440 & 1048 \\
\hline
\end{tabular}




\section{3.b. melléklet: A becsült és terítékre hozott tőkés réce, csörgő réce és böjti réce átlagos mennyisége a vadászidényben ökorégiónként}

Appendix 23.b.: Average number and bag size of Mallard, Eurasian Teal and Garganey in hunting seasons in each eco-regions

\begin{tabular}{|c|c|c|c|c|c|c|c|c|c|c|c|c|c|c|c|c|c|c|c|c|}
\hline Tőkés réce & ڤิڤ & $\stackrel{\infty}{\stackrel{5}{\sigma}}$ & $\underset{\hat{\sigma}}{\stackrel{\circ}{\sigma}}$ & ڤัેু & ڤ్̀ે & 气ิ & ֻิ & 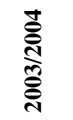 & 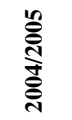 & 高 & 仓ิ & 高 & 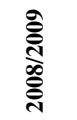 & 응 & 竎 & ב⿳亠口冋亍 & 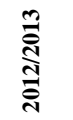 & 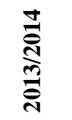 & & 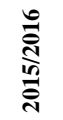 \\
\hline Észak-Dunánt & 7859 & 16232 & 11369 & 17431 & 23708 & 18273 & 12447 & 7823 & 12956 & 12943 & 10429 & 12974 & 15599 & 9260 & 8926 & 12961 & 13891 & 11931 & 9122 & 11831 \\
\hline Észak-Dunántúl (teríték) & 10700 & 10081 & 14845 & 12409 & 11339 & 10457 & 7332 & 10530 & 5992 & 5573 & 6377 & 8012 & 8108 & 6891 & 7209 & 6610 & 7412 & 8243 & 6174 & 8294 \\
\hline Dél-Dunántúl (becslés) & 8442 & 9140 & 9871 & 13392 & 4628 & 6053 & 5833 & 3985 & 5812 & 5687 & 2344 & 6751 & 2001 & 2691 & 3134 & 2804 & 4112 & 2905 & 3351 & 3376 \\
\hline Dél-Dunántúl (teríték) & 9206 & 10130 & 8422 & 9120 & 7214 & 10818 & 8068 & 6059 & 5361 & 4453 & 4964 & 6889 & 4165 & 3826 & 6566 & 5405 & 7431 & 4654 & 3651 & 3919 \\
\hline Duna-Tisza köze (becslés) & 7590 & 4802 & 5909 & 11240 & 5563 & 6509 & 2626 & 5066 & 6557 & 8780 & 7713 & 5917 & 5793 & 5538 & 5564 & 8499 & 2398 & 5844 & 3781 & 7168 \\
\hline Duna-Tisza köze (teríték) & 9942 & 8991 & 9813 & 14325 & 10732 & 9670 & 8064 & 6242 & 7154 & 6574 & 7952 & 9656 & 8847 & 8554 & 6757 & 8459 & 8169 & 7528 & 4818 & 6651 \\
\hline Tiszántúl (becslés) & 3853 & 02 & 138 & 5076 & 3281 & 2748 & 2785 & 93 & 6 & 34768 & 82 & 11 & 240 & 17 & 01 & 21640 & 14724 & 25931 & 239 & 4990 \\
\hline Tiszántúl (teríték) & 22357 & 29254 & 25500 & 41666 & 51242 & 44477 & 31179 & 22622 & 25219 & 24629 & 28649 & 26924 & 25062 & 14775 & 20248 & 33880 & 19170 & 22883 & 15207 & 18399 \\
\hline $\begin{array}{l}\text { Magyarország összesen } \\
\text { (becslés) } \\
\text { Magyarország összesen } \\
\text { (teríték) }\end{array}$ & 24 & 591 & 5853 & 9283 & 89850 & 5831 & 4875 & 362 & 6500 & 62178 & 48715 & 46769 & 35802 & 4221 & 37816 & 45903 & 3512 & 4661 & 4015 & 47365 \\
\hline
\end{tabular}

\begin{tabular}{|c|c|c|c|c|c|c|c|c|c|c|c|c|c|c|c|c|}
\hline Csörg & $\frac{\hat{\sigma}}{\stackrel{\sigma}{\sigma}}$ & 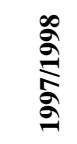 & $\begin{array}{l}\stackrel{\partial}{\sigma} \\
\stackrel{\partial}{\sigma} \\
\stackrel{\sigma}{\sigma}\end{array}$ & 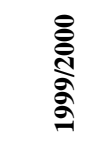 & $\begin{array}{l}\bar{\delta} \\
\stackrel{్}{8} \\
\stackrel{్}{8}\end{array}$ & 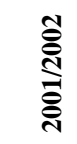 & 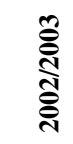 & 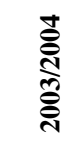 & 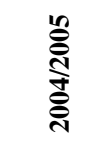 & 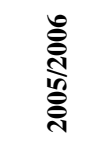 & 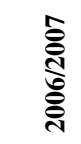 & 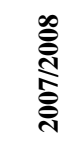 & 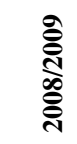 & 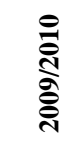 & 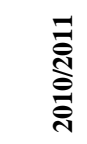 & 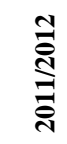 \\
\hline Észak-Dunántúl (becslés) & 1744 & 3277 & 3658 & 2713 & 3750 & 1421 & 1779 & 1912 & 1895 & 1960 & 1636 & 3690 & 1977 & 981 & 969 & 1866 \\
\hline Észak-Dunántúl (teríték) & 435 & 454 & 381 & 396 & 467 & 295 & 213 & 117 & 263 & 167 & 167 & 429 & 374 & 201 & 156 & 248 \\
\hline Dél-Dunántúl (becslés) & 693 & 470 & 850 & 1915 & 1299 & 1417 & 1158 & 1027 & 370 & 196 & 2232 & 610 & 313 & 665 & 197 & 358 \\
\hline Dél-Dunántúl (teríték) & 498 & 129 & 403 & 398 & 208 & 178 & 138 & 104 & 162 & 261 & 142 & 264 & 101 & 261 & 168 & 128 \\
\hline Duna-Tisza köze & 1437 & 459 & 1350 & 3053 & 1165 & 1549 & 122 & 361 & 721 & 1010 & 481 & 243 & 197 & 328 & 2588 & 474 \\
\hline Duna-Tisza köze (teríték) & 933 & 573 & 761 & 1180 & 631 & 994 & 245 & 260 & 150 & 239 & 345 & 481 & 372 & 301 & 459 & 297 \\
\hline Tiszántúl (becslés) & 2323 & 3565 & 4609 & 8380 & 6042 & 5297 & 3670 & 3489 & 7763 & 7848 & 6605 & 3344 & 3788 & 5396 & 7441 & 3139 \\
\hline Tiszántúl (teríték) & 1337 & 2989 & 2629 & 2322 & 3191 & 3741 & 1831 & 1932 & 1536 & 1428 & 1956 & 2213 & 1483 & 1570 & 669 & 1116 \\
\hline Magyarország összesen (becslés) & 16197 & 7771 & 10467 & 16061 & 12256 & 9684 & 6729 & 6789 & 10749 & 11013 & 10953 & 7887 & 6274 & 7370 & 11195 & 5836 \\
\hline Magyarország összesen (ter & 4334 & 4364 & 4403 & $\mathbf{5 2 7 7}$ & 6156 & 6657 & 2669 & 2552 & 2177 & 2204 & 3218 & 3729 & 2513 & 2535 & 1539 & 1927 \\
\hline
\end{tabular}

\begin{tabular}{|c|c|c|c|c|c|c|c|c|c|c|c|}
\hline Böjti réce & \begin{tabular}{l}
$\hat{\sigma}$ \\
\multirow{2}{\sigma}{} \\
$\circ$
\end{tabular} & $\stackrel{\infty}{\stackrel{\circ}{\sigma}}$ & $\begin{array}{l}\stackrel{\circ}{\partial} \\
\stackrel{\circ}{\circ} \\
\stackrel{\sigma}{\sigma}\end{array}$ & 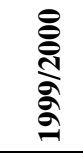 & 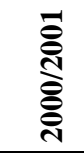 & 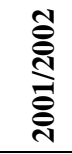 & 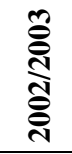 & 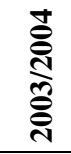 & 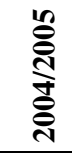 & 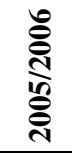 & 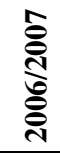 \\
\hline Észak-Dunántúl (becslés) & 0 & 80 & 430 & 212 & 76 & 241 & 63 & 46 & 2 & 1 & 21 \\
\hline Észak-Dunántúl (teríték) & 74 & 62 & 59 & 129 & 83 & 40 & 73 & 32 & 32 & 42 & 14 \\
\hline Dél-Dunántúl (becslés) & 0 & 12 & 71 & 0 & 78 & 27 & 15 & 17 & 0 & 0 & 0 \\
\hline Dél-Dunántúl (teríték) & 115 & 136 & 419 & 131 & 43 & 44 & 40 & 23 & 23 & 40 & 10 \\
\hline Duna-Tisza köze (becslés) & 0 & 0 & 170 & 68 & 15 & 7 & 0 & 0 & 0 & 0 & 1 \\
\hline Duna-Tisza köze (teríték) & 229 & 361 & 784 & 485 & 135 & 121 & 78 & 52 & 52 & 7 & 20 \\
\hline Tiszántúl (becslés) & 0 & 124 & 108 & 504 & 270 & 86 & 151 & 71 & 0 & 50 & 8 \\
\hline Tiszántúl (teríték) & 351 & 463 & 667 & 358 & 690 & 624 & 293 & 190 & 190 & 100 & 57 \\
\hline Magyarország összesen (becslés) & $\mathbf{0}$ & 216 & 779 & 784 & 439 & 361 & 229 & 134 & 2 & 51 & 30 \\
\hline Magyarország összesen (teríték) & 841 & 1067 & 2046 & 1426 & 1011 & 854 & 517 & 310 & 310 & 189 & 121 \\
\hline
\end{tabular}




\section{3.c. melléklet: A becsült és terítékre hozott barátréce, kerceréce és szárcsa átlagos mennyisége a vadászidényben ökorégiónként}

Appendix 23.b.: Average number and bag size of Common Pochard, Common Goldeneye and Eurasian Coot in hunting seasons in each eco-regions

\begin{tabular}{|c|c|c|c|c|c|c|c|c|c|c|c|c|}
\hline Bará & $\begin{array}{l}\hat{\sigma} \\
\frac{\hat{\sigma}}{\sigma}\end{array}$ & $\underset{\sigma}{\stackrel{\sigma}{\sigma}}$ & $\frac{\stackrel{\partial}{\partial}}{\stackrel{\alpha}{\sigma}}$ & 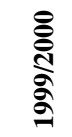 & 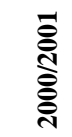 & 悹 & 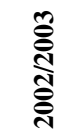 & 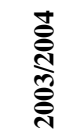 & 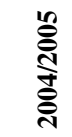 & 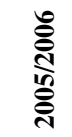 & 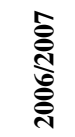 & 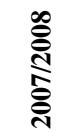 \\
\hline Észak-Dunántúl (be & 223 & 217 & 562 & 168 & 285 & 332 & 282 & 213 & 228 & 391 & 331 & 203 \\
\hline Észak-Dunántúl (teríték) & 317 & 192 & 187 & 222 & 245 & 157 & 96 & 66 & 55 & 52 & 34 & 90 \\
\hline Dél-Dunántúl (becslés) & 1088 & 765 & 436 & 1082 & 1248 & 724 & 518 & 303 & 517 & 506 & 434 & 710 \\
\hline Dél-Dunántúl (teríték) & 117 & 18 & 99 & 101 & 66 & 60 & 83 & 51 & 80 & 60 & 14 & 25 \\
\hline Duna-Tisza köze (becslés) & 449 & 68 & 628 & 3 & 169 & 254 & 114 & 148 & 31 & 294 & 113 & 278 \\
\hline Duna-Tisza köze (teríték) & 23 & 176 & 238 & 397 & 197 & 189 & 113 & 89 & 7 & 62 & 108 & 50 \\
\hline Tiszántúl (becslés) & 1074 & 1037 & 956 & 448 & 305 & 979 & 548 & 1034 & 1350 & 1393 & 1164 & 882 \\
\hline Tiszántúl (teríték) & 1173 & 1691 & 2254 & 1915 & 1182 & 748 & 577 & 321 & 306 & 163 & 275 & 277 \\
\hline Magyarország öss & 2834 & 2087 & 2582 & 1701 & 2007 & 2289 & 1462 & 1698 & 2126 & 2584 & 2042 & 2072 \\
\hline Magyarország összesen (teríték) & 1746 & 2135 & 2852 & 3075 & 1805 & 1176 & 900 & 537 & 450 & 339 & 434 & 448 \\
\hline
\end{tabular}

\begin{tabular}{|c|c|c|c|c|c|c|c|c|c|c|c|c|c|c|c|c|c|c|c|c|}
\hline Kerceréce & & & 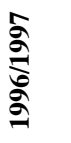 & $\stackrel{\circ}{\stackrel{5}{\circ}}$ & $\underset{\partial}{\stackrel{\partial}{\sigma}}$ & 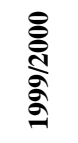 & 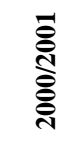 & 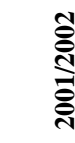 & 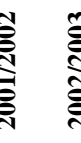 & 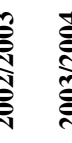 & 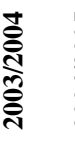 & 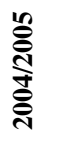 & 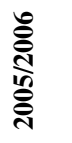 & 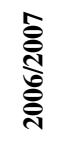 & 离 & 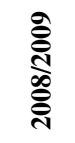 & & 옳 & 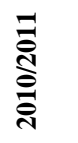 & 곯 \\
\hline Észak-Dunántúl (becslés) & & & 1047 & 598 & 1035 & 1309 & 537 & $37 \quad 8$ & 8606 & $666 \quad 6$ & 694 & 697 & 1186 & 555 & 1367 & 1514 & & 924 & 959 & 593 \\
\hline Észak-Dunántúl (teríték) & & & 20 & 27 & 5 & 18 & & 94 & 5 & 10 & 4 & 2 & 0 & 0 & 0 & & 1 & 1 & 9 & 2 \\
\hline Dél-Dunántúl (becslés) & & & 327 & 151 & 177 & 1066 & 51330 & $\begin{array}{ll}30 & 1\end{array}$ & 137 & 821 & 160 & 577 & 199 & 245 & 140 & 347 & 17 & 815 & 79 & 287 \\
\hline Dél-Dunántúl (teríték) & & & 1 & 1 & 12 & 2 & & 0 & 8 & 9 & 2 & 20 & 7 & 54 & 35 & & 0 & 4 & 6 & 0 \\
\hline Duna-Tisza köze (becslés) & & & 363 & 48 & 190 & 310 & & 172 & 2141 & 1161 & 106 & 34 & 115 & 29 & 278 & & 71 & 33 & 221 & 8 \\
\hline Duna-Tisza köze (teríték) & & & 0 & 50 & 83 & 47 & & 12 & 50 & 22 & 25 & 11 & 8 & 12 & 11 & & 14 & 84 & 18 & 0 \\
\hline Tiszántúl (becslés) & & & 22 & 133 & 42 & 56 & & 41 & 16 & 23 & 25 & 96 & 30 & 35 & 28 & & 29 & 42 & 34 & 28 \\
\hline Tiszántúl (teríték) & & & 302 & 378 & 90 & 111 & 637 & 37 & 2621 & 143 & 27 & 23 & 20 & 20 & 137 & & 37 & 65 & 11 & 10 \\
\hline Magyarország összesen ( & lés) & & 1759 & 930 & 1444 & 2741 & 1925 & 2512 & 2278 & 8879 & 985 & 1404 & 1530 & 863 & 1812 & 1960 & & 1813 & 1293 & 915 \\
\hline Magyarország összesen & ék) & & 326 & 456 & 214 & 248 & 755 & 553 & 3301 & 184 & 58 & 59 & 35 & 86 & 183 & 52 & 52 & 154 & 44 & 30 \\
\hline Szárcsa & ڤે & $\stackrel{\circ}{\stackrel{5}{\sigma}}$ & $\begin{array}{l}\stackrel{\partial}{\partial} \\
\stackrel{\circ}{\sigma}\end{array}$ & $\begin{array}{l}\text { ลิ } \\
\text { ลू }\end{array}$ & 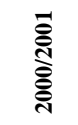 & 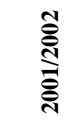 & 言 & 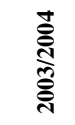 & 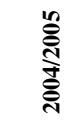 & 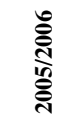 & 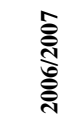 & 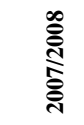 & 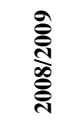 & 옳 & 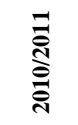 & 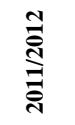 & 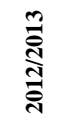 & 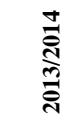 & 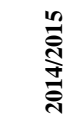 & 突 \\
\hline szak-Dunántúl (becslés) & 311 & 296 & 1035 & 996 & 452 & 1267 & 1474 & 1103 & 1181 & 2872 & 1412 & 1208 & 1432 & 1399 & 1181 & 771 & 599 & 1258 & 1067 & 954 \\
\hline Észak-Dunántúl (teríték) & 1581 & 1261 & 621 & 1520 & 700 & 870 & 404 & 348 & 216 & 239 & 170 & 451 & 536 & 330 & 505 & 377 & 554 & 116 & 145 & 185 \\
\hline Dél-Dunántúl (becslés) & 2106 & 2633 & 177 & 2932 & 2997 & 2963 & 2418 & 793 & 1240 & 1542 & 2137 & 946 & 1557 & 1442 & 14862 & 2185 & 797 & 1129 & 1255 & 1753 \\
\hline Dél-Dunántúl (teríték) & 698 & 514 & 892 & 770 & 424 & 365 & 449 & 172 & 229 & 172 & 145 & 199 & 129 & 123 & 132 & 175 & 141 & 82 & 152 & 118 \\
\hline Duna-Tisza köze (becslés) & 79 & 19 & 190 & 68 & 3 & 40 & 19 & 20 & 16 & 44 & 10 & 131 & 83 & 163 & 202 & 15 & 12 & 4 & 21 & 41 \\
\hline Duna-Tisza köze (teríték) & 595 & 598 & 631 & 913 & 678 & 589 & 179 & 316 & 443 & 499 & 480 & 288 & 340 & 324 & 722 & 346 & 237 & 148 & 339 & 371 \\
\hline Tiszántúl (becslés) & 4839 & 1307 & 42 & 1989 & 2029 & 5947 & 32803 & 3793 & 5499 & 2811 & 3830 & 3293 & 3869 & 4239 & 2342 & 34151 & 1277 & 2218 & 2767 & 2660 \\
\hline Гiszántúl (teríték) & 1266 & 1791 & 3998 & 2731 & 1859 & 1521 & 992 & 918 & 1153 & 1732 & 2377 & 1028 & 909 & 762 & 1333 & 1342 & 366 & 1549 & 581 & 378 \\
\hline $\begin{array}{l}\text { Magyarország összesen } \\
\text { (becslés) } \\
\text { Magyarország összesen } \\
\text { (teríték) }\end{array}$ & $\begin{array}{r}7335 \\
4253 \\
\end{array}$ & $\begin{array}{r}4255 \\
4264 \\
\end{array}$ & $\begin{array}{r}1444 \\
6356 \\
\end{array}$ & $\begin{array}{r}5985 \\
6407 \\
\end{array}$ & $\begin{array}{r}5481 \\
4387 \\
\end{array}$ & $\begin{array}{r}10217 \\
3427 \\
\end{array}$ & $\begin{array}{l}7191 \\
2066\end{array}$ & $\begin{array}{r}5709 \\
1782 \\
\end{array}$ & $\begin{array}{r}7935 \\
2101 \\
\end{array}$ & $\begin{array}{r}7268 \\
2985 \\
\end{array}$ & $\begin{array}{r}7388 \\
3326 \\
\end{array}$ & $\begin{array}{l}5578 \\
2062 \\
\end{array}$ & $\begin{array}{l}6942 \\
1946 \\
\end{array}$ & $\begin{array}{r}7244 \\
1573 \\
\end{array}$ & $\begin{array}{l}5210 \\
2702 \\
\end{array}$ & $\begin{array}{l}63862 \\
2274 \quad 1 \\
\end{array}$ & $\begin{array}{l}2686 \\
1323 \\
\end{array}$ & $\begin{array}{r}4609 \\
1897 \\
\end{array}$ & $\begin{array}{r}5110 \\
1223 \\
\end{array}$ & $\begin{array}{r}5408 \\
1181 \\
\end{array}$ \\
\hline
\end{tabular}




\section{4. melléklet: Vadászatra kihelyezett tôkés réce regionális eloszlása Magyarországon} Appendix 24: Regional dispersion of released hand reared Mallard for shooting in Hungary 1994-2011

\begin{tabular}{|c|c|c|c|c|c|c|c|c|c|c|c|c|c|c|c|c|c|}
\hline $\begin{array}{l}\text { Régió } \\
\text { Region }\end{array}$ & $\stackrel{2}{\frac{2}{2}}$ & ڤે & $\underset{\sigma}{\stackrel{5}{\sigma}}$ & $\underset{\partial}{\stackrel{\circ}{े}}$ & 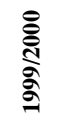 & 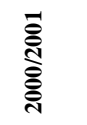 & 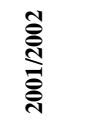 & 气ิે & 言 & 㒕 & 雍 & 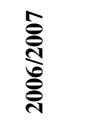 & 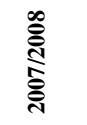 & 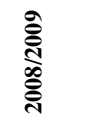 & 옿 & 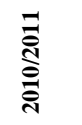 & בָב \\
\hline $\begin{array}{l}\text { É-Dunántúl } \\
\text { N. Transdanubia }\end{array}$ & 28215 & 37875 & 19100 & 16649 & 38770 & 40000 & 38277 & 28103 & 28513 & 18570 & 19500 & 13975 & 21750 & 19800 & 10165 & 17839 & 14593 \\
\hline $\begin{array}{l}\text { Dél-Dunántúl } \\
\text { S. Transdanubia }\end{array}$ & 26195 & 24638 & 13440 & 18290 & 9720 & 16000 & 17600 & 18980 & 21900 & 16800 & 8100 & 17000 & 15900 & 13500 & 11710 & 25665 & 12131 \\
\hline $\begin{array}{l}\text { É-Magyarország } \\
\text { N. Hungary }\end{array}$ & 19823 & 28700 & 40700 & 29380 & 23960 & 26428 & 25500 & 24400 & 29180 & 29660 & 31560 & 27380 & 19700 & 26650 & 9000 & 13260 & 15500 \\
\hline $\begin{array}{l}\text { Duna-Tisza köze } \\
\text { Danube-Tisza } \\
\text { Interfluve }\end{array}$ & 15702 & 14260 & 14662 & 17516 & 23540 & 19384 & 15673 & 13346 & 6600 & 4250 & 4880 & 1750 & 3250 & 1920 & 3450 & 5500 & 3800 \\
\hline $\begin{array}{l}\text { Tiszántúl } \\
\text { Transtisz }\end{array}$ & 46383 & 51837 & 75447 & 74914 & 93927 & 100606 & 116543 & 111863 & 114371 & 108770 & 98366 & 77220 & 86337 & 59938 & 57239 & 73627 & 77038 \\
\hline $\begin{array}{l}\text { Magyarország össz. } \\
\text { Hungary total }\end{array}$ & 136318 & 157310 & 163349 & 156749 & 189917 & 202418 & 213593 & 196692 & 200564 & 178050 & 162406 & 137325 & 146937 & 121808 & 91564 & 135891 & 123062 \\
\hline
\end{tabular}

\begin{tabular}{|c|c|c|c|c|c|c|c|c|c|c|c|c|c|c|c|c|c|}
\hline $\begin{array}{l}\text { Régió } \\
\text { Region }\end{array}$ & $\stackrel{2}{2}$ & ڤ్ & $\stackrel{\infty}{\sigma}$ & $\underset{\text { مे }}{\stackrel{\sigma}{\circ}}$ & 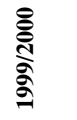 & 突 & 芯 & 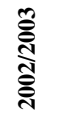 & 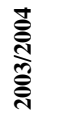 & 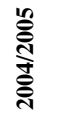 & 壱 & 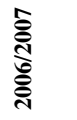 & 高 & 言 & 옿 & 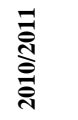 & 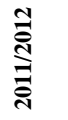 \\
\hline $\begin{array}{l}\text { É-Dunántúl } \\
\text { N. Transdanubia }\end{array}$ & $21 \%$ & $24 \%$ & $12 \%$ & $11 \%$ & $20 \%$ & $20 \%$ & $18 \%$ & $14 \%$ & $14 \%$ & $10 \%$ & $12 \%$ & $10 \%$ & $15 \%$ & $16 \%$ & $11 \%$ & $13 \%$ & $12 \%$ \\
\hline $\begin{array}{l}\text { Dél-Dunántúl } \\
\text { S. Transdanubia }\end{array}$ & $19 \%$ & $16 \%$ & $8 \%$ & $12 \%$ & $5 \%$ & $8 \%$ & $8 \%$ & $10 \%$ & $11 \%$ & $9 \%$ & $5 \%$ & $12 \%$ & $11 \%$ & $11 \%$ & $13 \%$ & $19 \%$ & $10 \%$ \\
\hline $\begin{array}{l}\text { É-Magyarország } \\
\text { N. Hungary }\end{array}$ & $15 \%$ & $18 \%$ & $25 \%$ & $19 \%$ & $13 \%$ & $13 \%$ & $12 \%$ & $12 \%$ & $15 \%$ & $17 \%$ & $19 \%$ & $20 \%$ & $13 \%$ & $22 \%$ & $10 \%$ & $10 \%$ & $13 \%$ \\
\hline $\begin{array}{l}\text { Duna-Tisza köze } \\
\text { Danube-Tisza } \\
\text { Interfluve }\end{array}$ & $12 \%$ & $9 \%$ & $9 \%$ & $11 \%$ & $12 \%$ & $10 \%$ & $7 \%$ & $7 \%$ & $3 \%$ & $2 \%$ & $3 \%$ & $1 \%$ & $2 \%$ & $2 \%$ & $4 \%$ & $4 \%$ & $3 \%$ \\
\hline $\begin{array}{l}\text { Tiszántúl } \\
\text { Transtisz }\end{array}$ & $34 \%$ & $33 \%$ & $46 \%$ & $48 \%$ & $49 \%$ & $50 \%$ & $55 \%$ & $57 \%$ & $57 \%$ & $61 \%$ & $61 \%$ & $56 \%$ & $59 \%$ & $49 \%$ & $63 \%$ & $54 \%$ & $63 \%$ \\
\hline $\begin{array}{l}\text { Magyarország össz. } \\
\text { Hungary total }\end{array}$ & $100 \%$ & $100 \%$ & $100 \%$ & $100 \%$ & $100 \%$ & $100 \%$ & $100 \%$ & $100 \%$ & $100 \%$ & $100 \%$ & $100 \%$ & $100 \%$ & $100 \%$ & $100 \%$ & $100 \%$ & $100 \%$ & $100 \%$ \\
\hline
\end{tabular}

